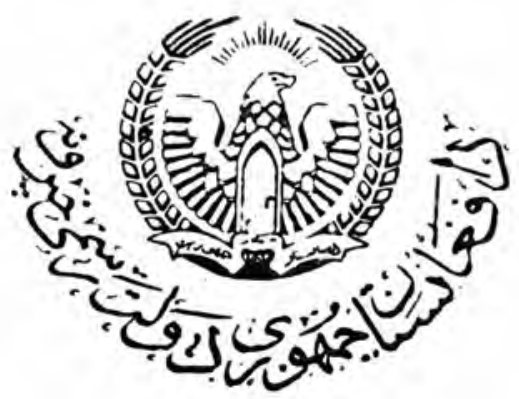

\title{
مانى قازون
}

\author{
تمهيدى باب

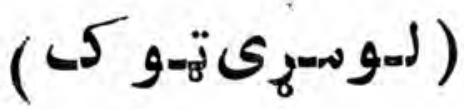




\section{فه-ر سهت

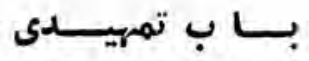 \\ مادة (EAr-1)}

ماده صفحه

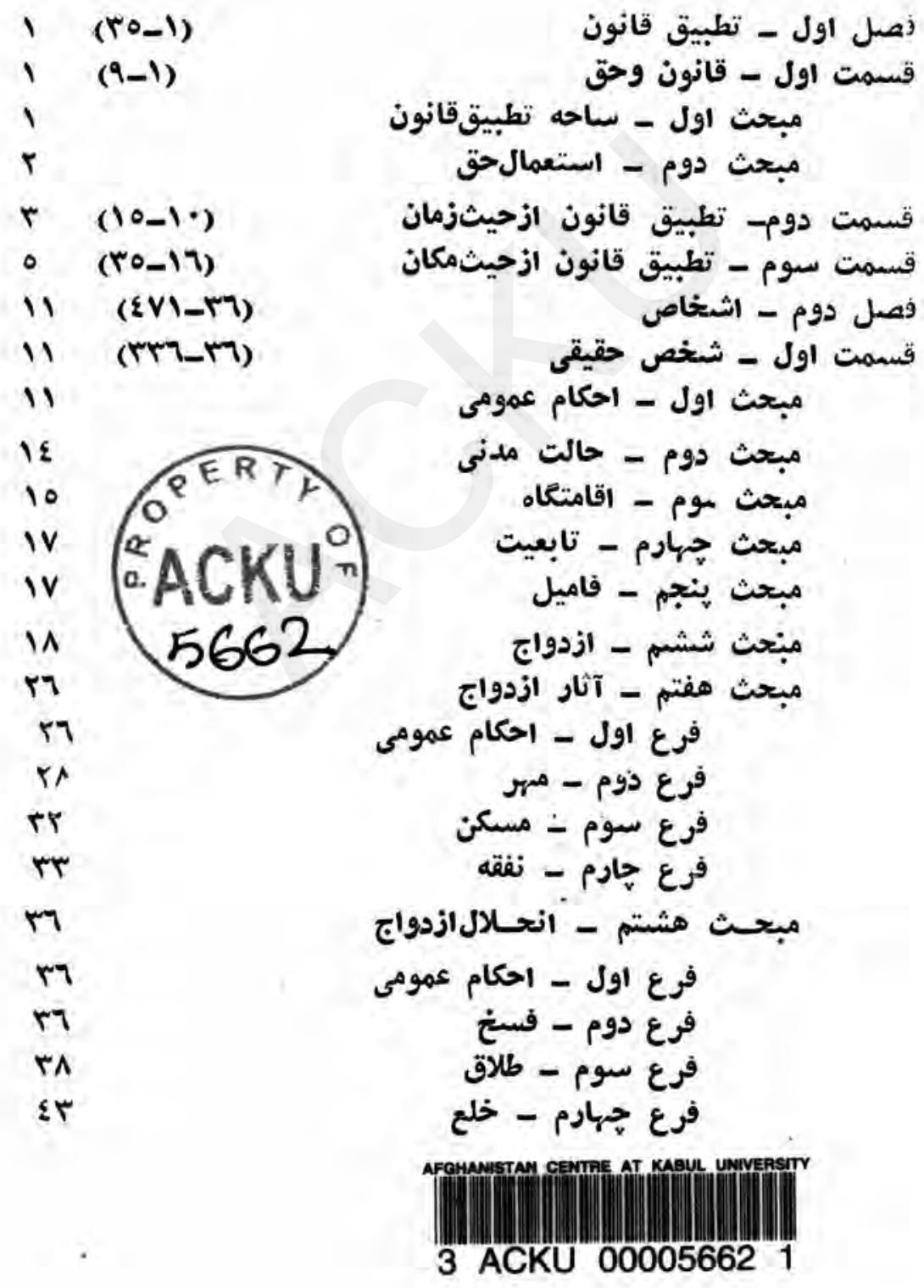




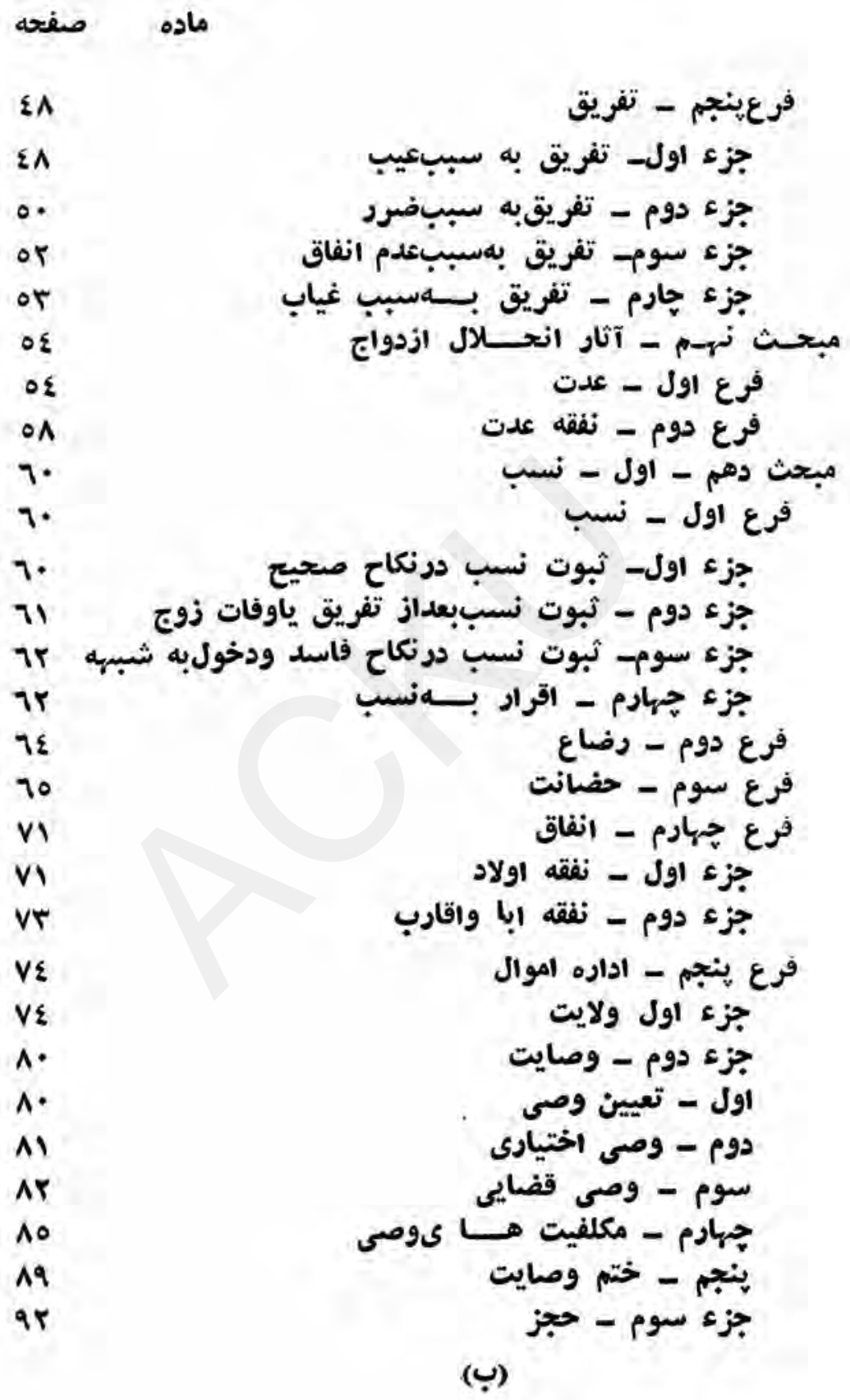


ماده صفحه

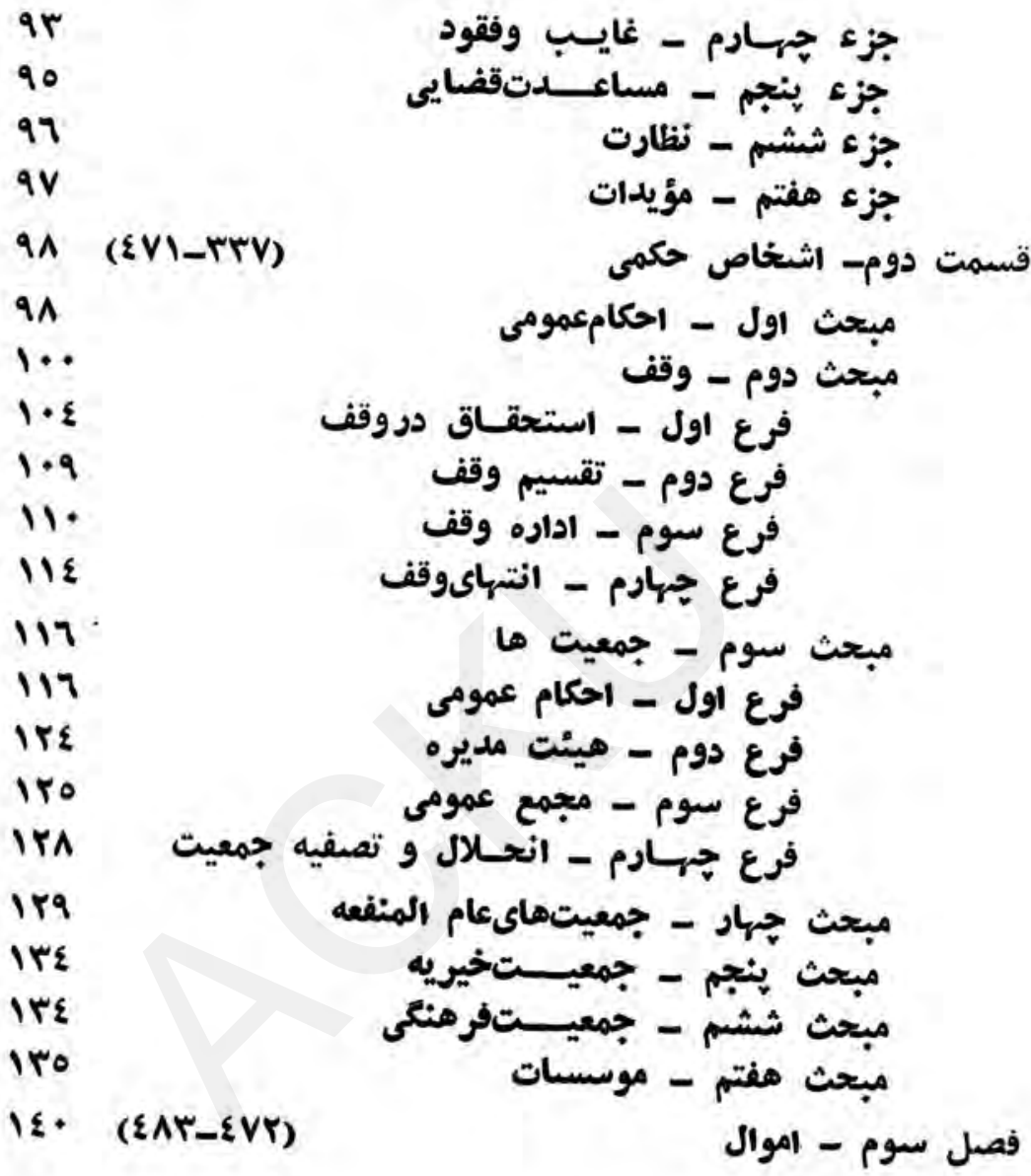

(द) 


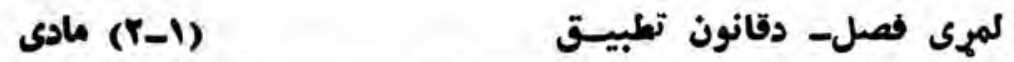

$$
\begin{aligned}
& \text { قا زهو ن مسل نسى } \\
& \text { مه زمى قـا ز-ون } \\
& \text { باب تهميله } \\
& \text { فعــــل } 1 \text { و ل } \\
& \text { تطبيـق قانــو ن }
\end{aligned}
$$

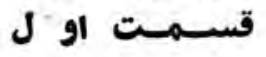

$$
\begin{aligned}
& \text { قـ نو ن و حــق } \\
& \text { لمسي ى فصـل } \\
& \text { دقانون تطبيـق } \\
& \text { لسمر في قسمت نسيت } \\
& \text { قـانو ن او حـق }
\end{aligned}
$$

\section{تممهيدى بـاب}

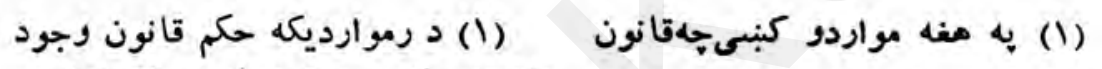

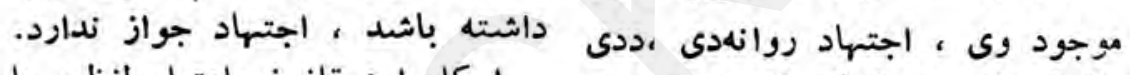

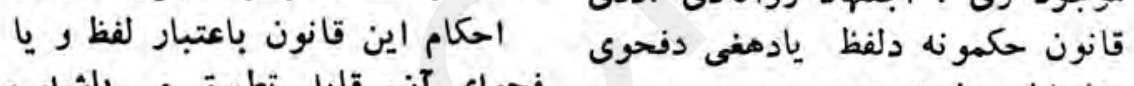

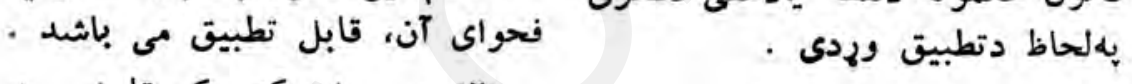

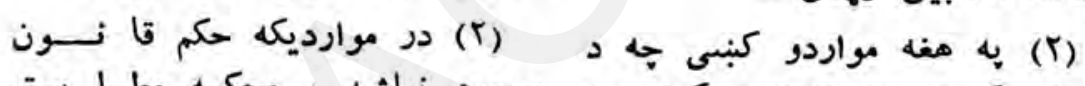

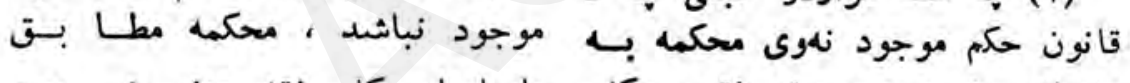

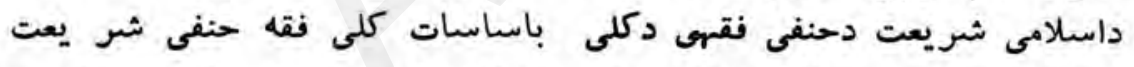

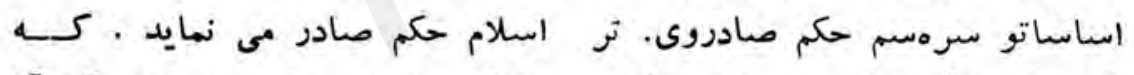

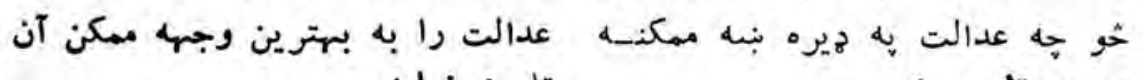

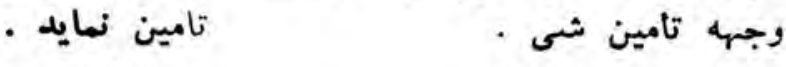

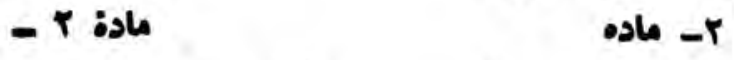

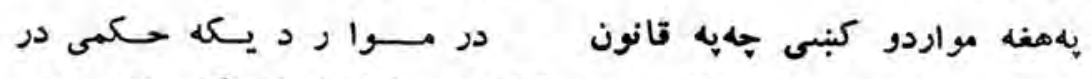

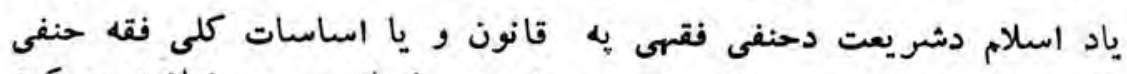

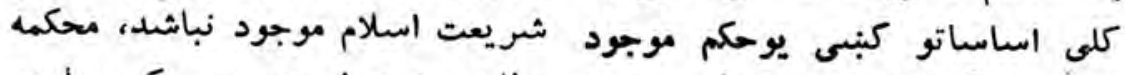

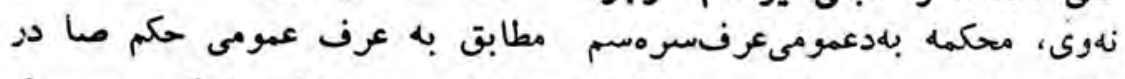

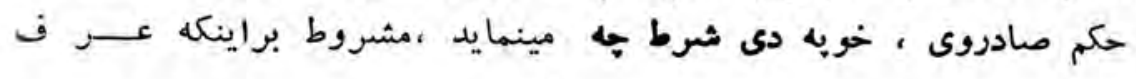




\section{مادى (A-r)}

\section{لمهى قسمت - قانون اوحت}

عرف ددى قانون د حكمونو يـا دـ مناقض احكام قانون يـــا اسأسات

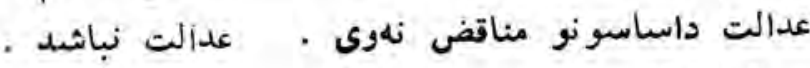
ماده r r r r

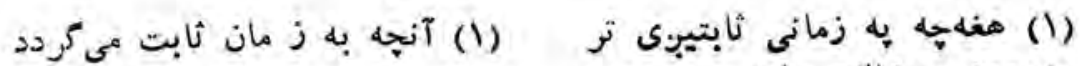

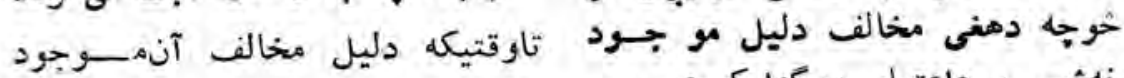

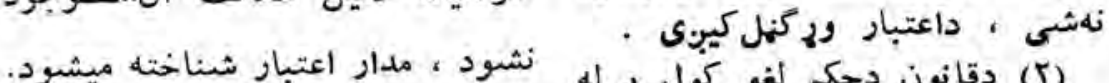

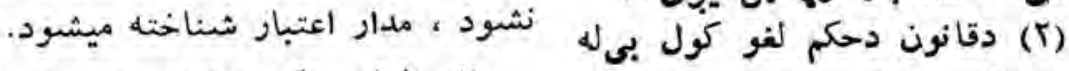

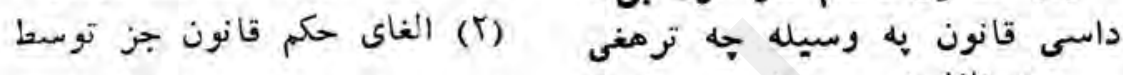

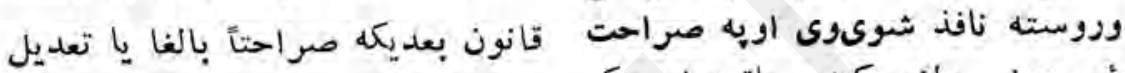
آنحكم نمايد،صورت كرفته نهيته

$$
\begin{aligned}
& \text { مبحث دوم - استعمال حق } \\
& \text { ماده }
\end{aligned}
$$

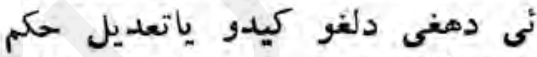

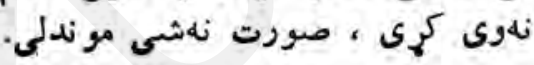
دوهم مبحث - دحق استعمال

$$
\text { ( - }
$$

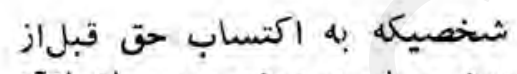

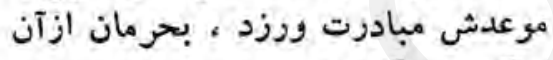

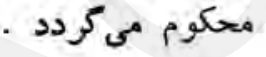

$$
\begin{aligned}
& \text { ماده }
\end{aligned}
$$

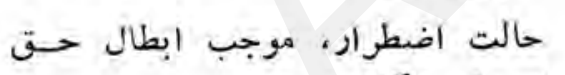

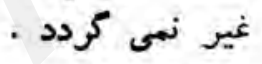$$
\text { ماده }
$$

ضرر توسط عمل بالمثل، أز بين

$$
\begin{aligned}
& \text { برده نمىثود . ماده } \\
& \text { ماده }
\end{aligned}
$$

مى داشع مفاسلد برجلب منافع هـقدم

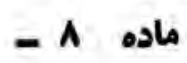

$$
\begin{aligned}
& \text { كه خوك دحت به بكسبه ولو دهغى }
\end{aligned}
$$

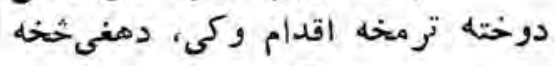

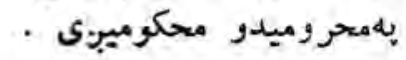

$$
\begin{aligned}
& \text { 0- ماده }
\end{aligned}
$$

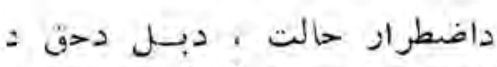

$$
\begin{aligned}
& \text { باطليدو موجب نه كرخى مارن }
\end{aligned}
$$

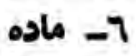

قانو نى جو از ضمان نغى كوى، ماده جواز قانونى ضما ن را نفى ميكند ، 
خوك دقانون يه حدودو كنبى دخهل شخصيكه از حقى خود در حدودقانون

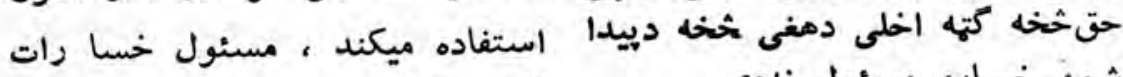

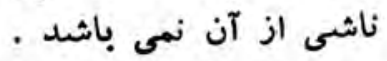

$$
\text { ماده }
$$

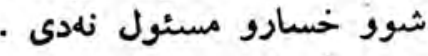

$$
\text { 9- ماده }
$$

نماند (1) شخصيكه از حق خود تهاون

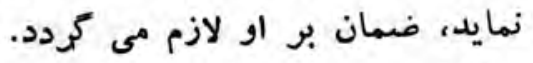

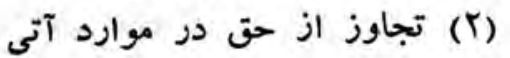

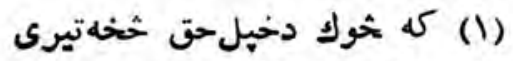

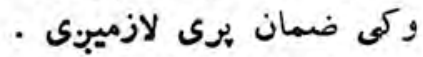

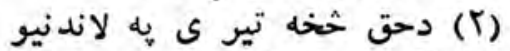

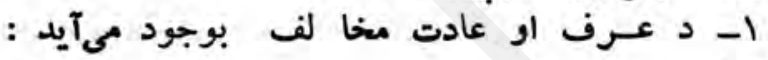
1- اعمال مخالف عرف مآد : وعادت r- داشتن قصد تعوض بـرحت

r- جزئى بودن مصلحت شخص غير نسبت بضرريكه بغير وارد ميسازد. ع- غير مجاز بودن مصلحت .

$$
\text { قسمه دوم }
$$

تطبيق قانون از حيث ز مـان

$$
\text { ماده - 1. - 1) }
$$

r- دبل يهانق بانــى دتيرى د قصد لول .

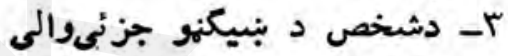
نسبت هغه ضرر ته جهبل ته تهن

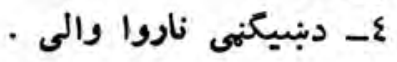

$$
\text { دوهم قسمت ناروان والى }
$$

دزمانى لهحيثه دقانون تطبيق

$$
\text { 1. }
$$

(1) احكام قانون بعد ازنشرقابل

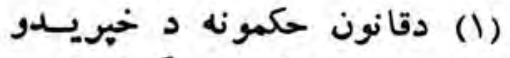

$$
\text { تطبيق مى احردد . احكام }
$$

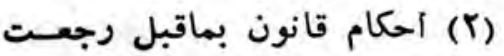

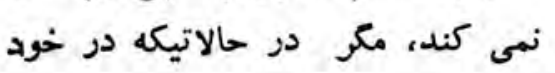
قابون تصريح شده و يا احكام آن متعلق به نظام عامه باشد . ماند ون

$$
\text { - } 11 \text { ماده }
$$

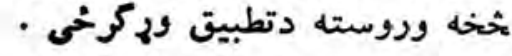

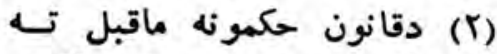

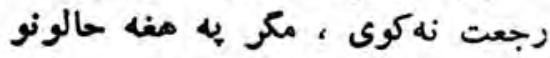

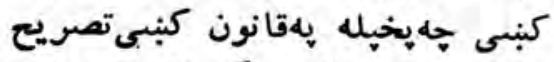

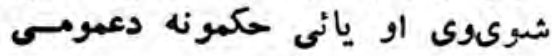

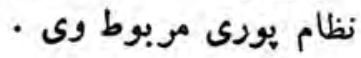

$$
\text { as - 11 }
$$

(1) احـعام متعلق با مليتبالاى

(1) دامليت يورى مربوط حكمنه 
بهتولو هغو اشخاصو جه ددىقانون جميع اشخاص واجد شروايط مندزج

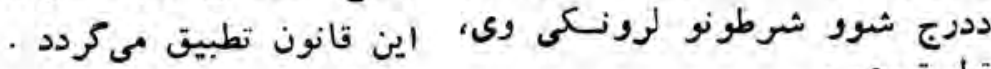

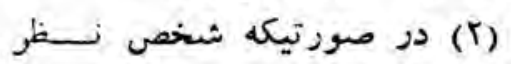

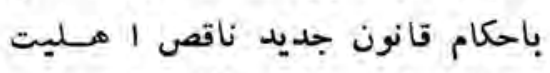

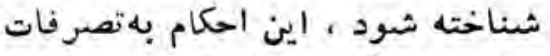

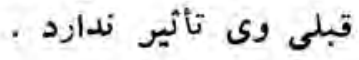
ماده

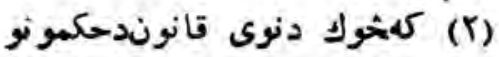

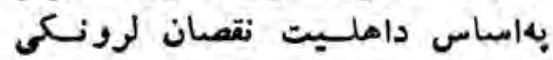

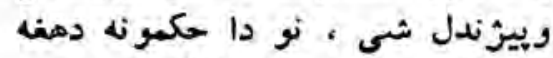

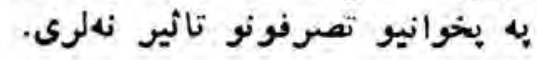

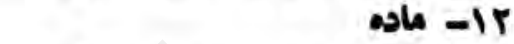

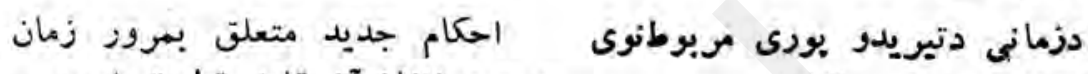

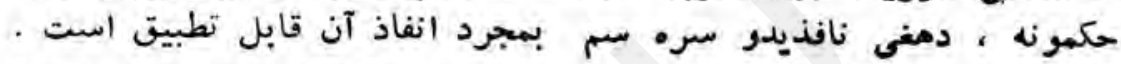

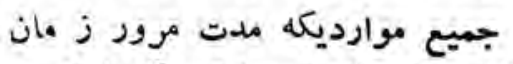

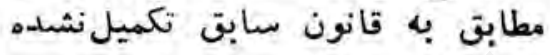

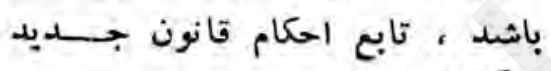
دتطبيق وريى · به تولو مواردو كنبى دمبن

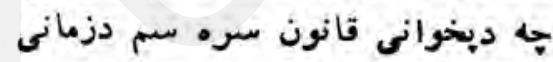

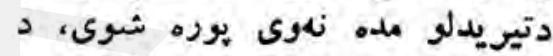

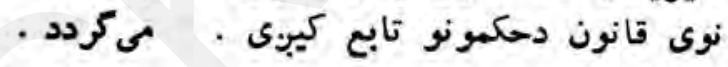

\section{ماده}

هركاه احكام قانون جديد مـاند

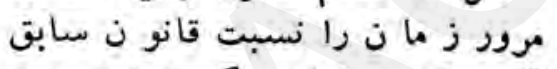

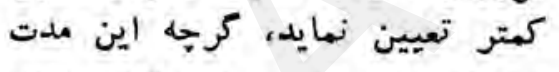
قبل از انفاذ قانون جديد آغاز يافته

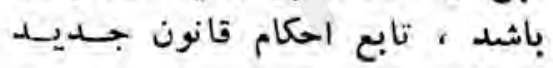
مىباثثد . ماشد ،

$$
\text { - IE مادم }
$$

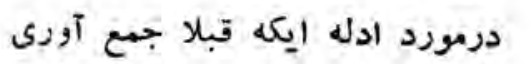
شده ، احكام قوانينى تطبيق مى ركردد كه در وقت جمع آورى ويا و قتيكه

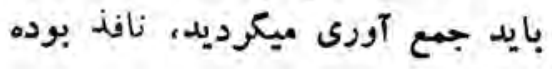
كع دنوى تانون حكمونه دزمانى

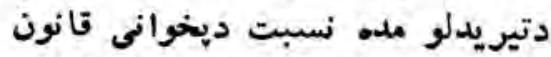

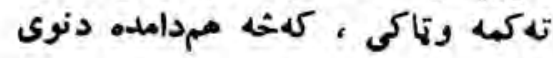

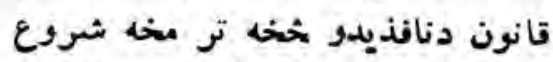

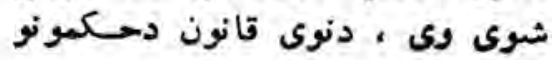
تابع دى : توى

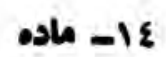

دمغه دليلونو يه مورد كبنس جه واته تومنه راتول شوى ، دمغه قوانيني

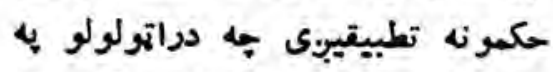

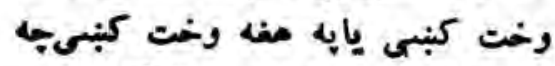

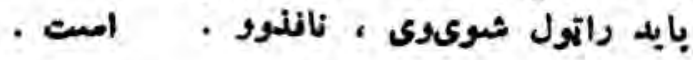




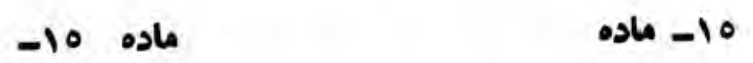

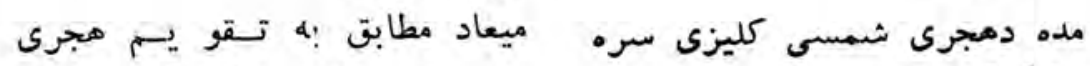

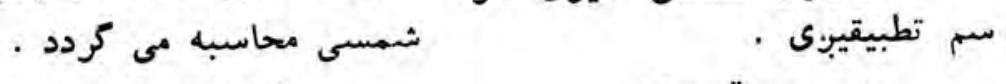

قسمت سوم محاسبه مئ

تطبيق قانون از حيث مكسن لومان

$$
\text { - } 17 \text { ماده }
$$

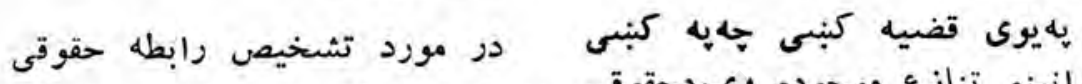
در قضيه ايكه تنازع قوانين در آن موجود كردد، احكام قانونافغانستان

$$
\begin{aligned}
& \text { قابل تطبيق مى باشد . مادود } \\
& \text { - IV ماده }
\end{aligned}
$$

در مورد تثبيت احوال مـدنى واده

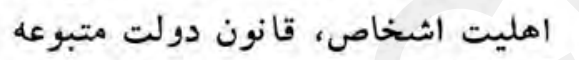

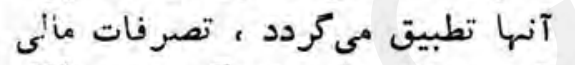

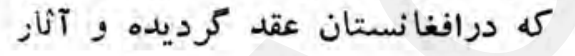

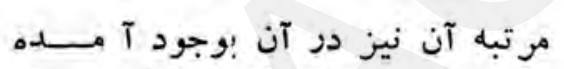

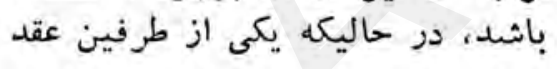

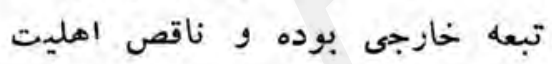
باشد طوريكه نقص اهليت آن مبنى بوده وني

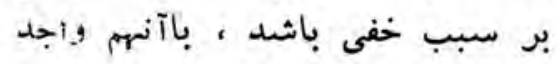

$$
\text { امليت كامل شنا خته ميشود . ماثد، مآنه }
$$

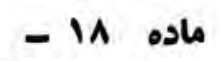

دزمورد اشخاص حكمى خاده خارحسى

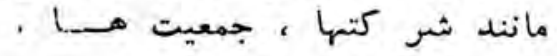

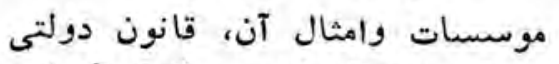
اعتبار دارد كه اداره مركزى آنهادي
دقوانينو تنازع موجوده وي،دوحقوقى

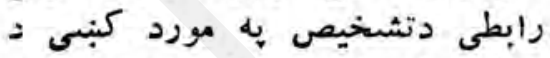
افغانستان دقانون حكمونه دون تطبيه وردى

$$
\text { -iv }
$$

دمدنى حسالونو اود اشخاصو مادون

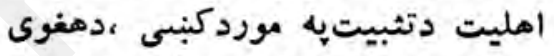

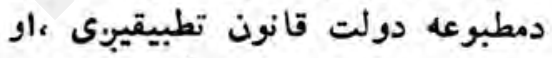
هيه هغه مالى تصرفونو كنبسى جه

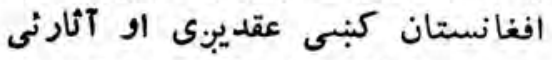

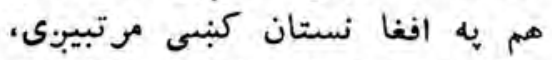

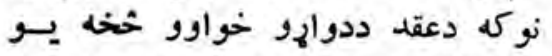

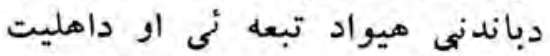
نقصان ولرى، خوداهليت نقصان نُّي أنى

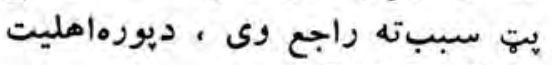

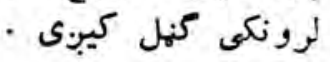

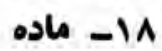

دباندنيو حكمى اشخاصويه مورد

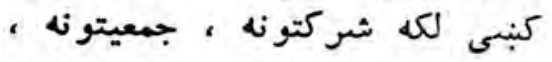
موسسى اونور ، دهغه دولت قانون اعتبار لرى جه دمغوى مركزى ادار• 


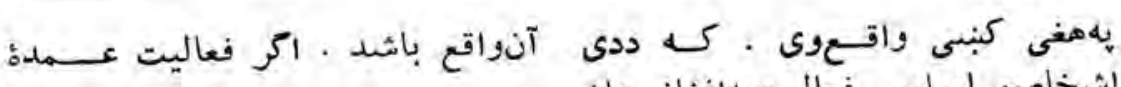

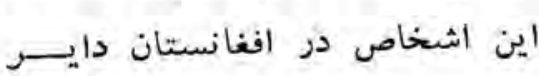
باشد قانون افغانستانتطبيقميكردد.

$$
\text { - } 19 \text { ماندان }
$$

اشخاصو اساسى فعاليت يهافئغانستان

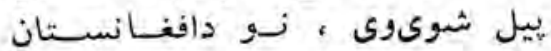

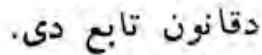

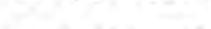

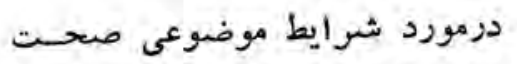

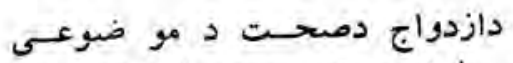

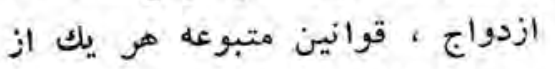

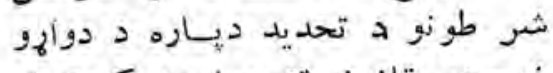
زوجين تطبيق ميكردد ،ودور شرايط إني

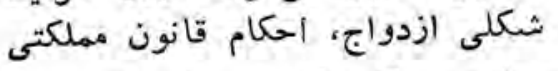

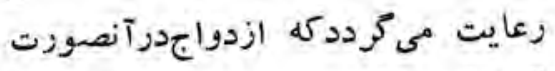

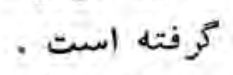

$$
\text { ماده }
$$

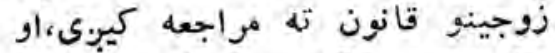

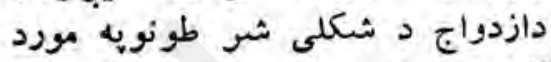

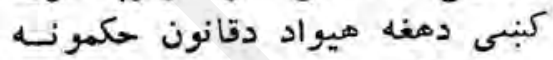

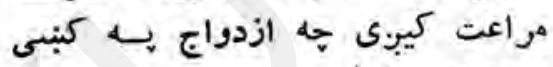

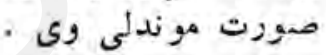
ماد $r$. (1) (1) مورد مورد آثار مرتبهبرازدواج

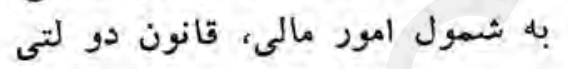

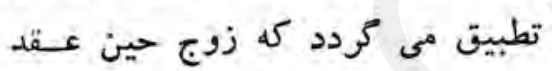

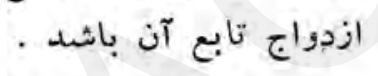

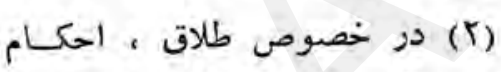
قانون دولتى تطبيق ميكردد كه زنج در حين طلاق تابع آن باشد . (r) در حالات تفريق و انسفصـال

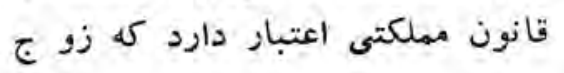
حين اقامه دعوى تابع آن باشد . مادون

$$
\text { ماده }
$$

در حالات مندرج مواد (19 و. (r)

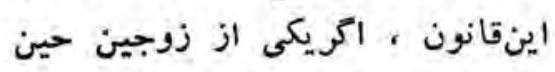

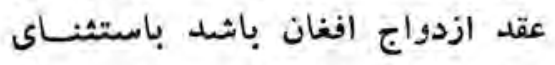

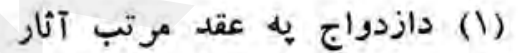

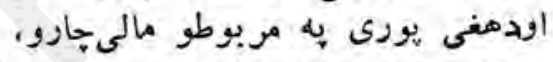

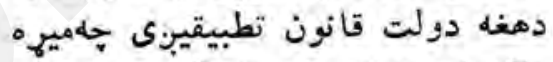

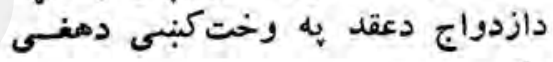

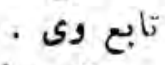

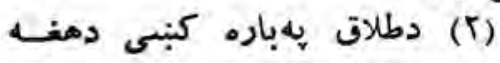
دولت دقانون حكمونه تطبيقيبنى جهاريه

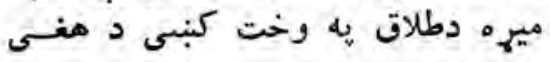
تابع وى . ميره

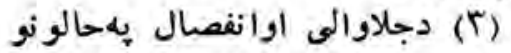

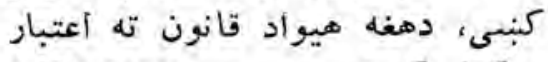

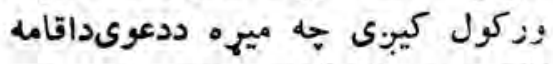
كيدو يه وخت كنبى دمغلى تابعوى

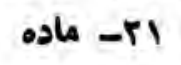

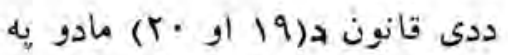
دزج شوو حالونو كنيى ،كلدزوجينو

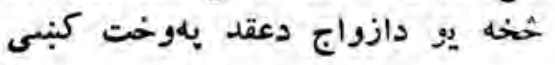


افغان وى ، نوداهليت د ثرطـونو شرط اهليت ، تنها احكام قـا نون

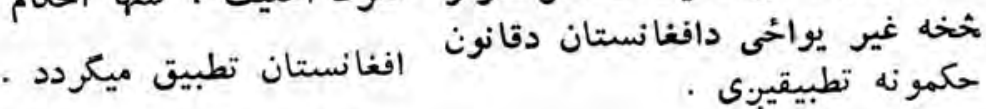

\section{- ماده} حكمونه تطبيقيبنى

دز مسايل متعلق بهبنوت، ولايت

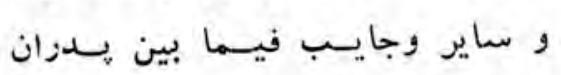
وفرزندان، احكام قانون دولتمتبوعه

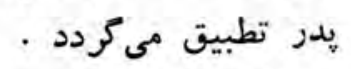
ماده هغه مسئلى جه دزوى ولى ولى، ولايت

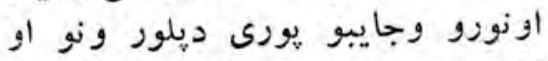

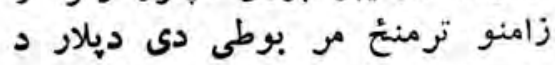

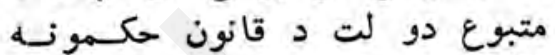

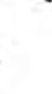

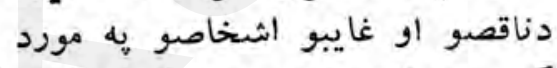

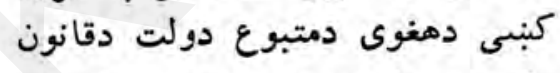

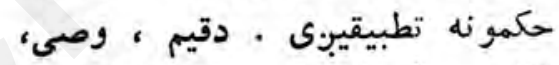

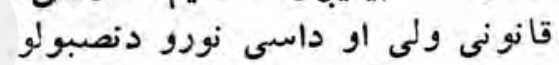

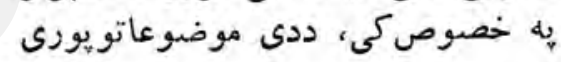

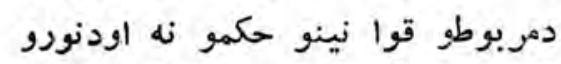

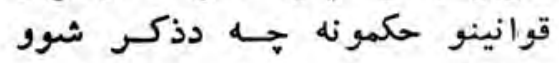

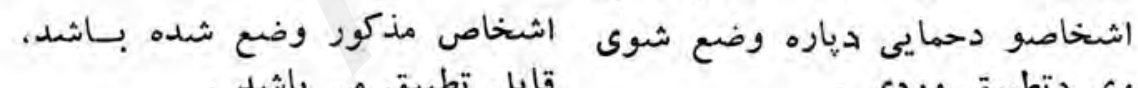

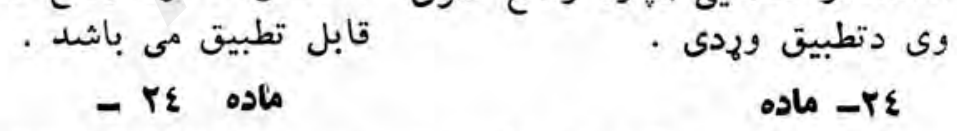

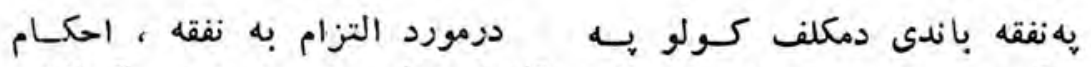

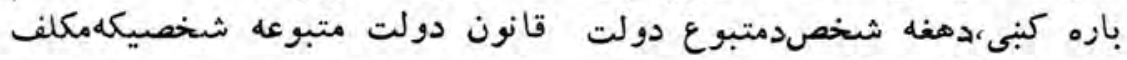

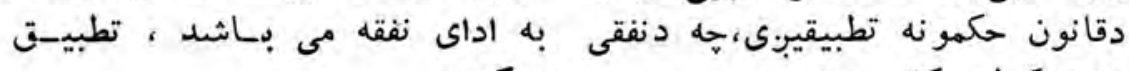

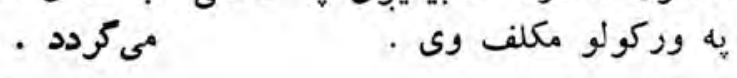

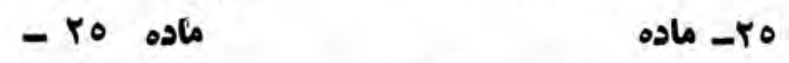

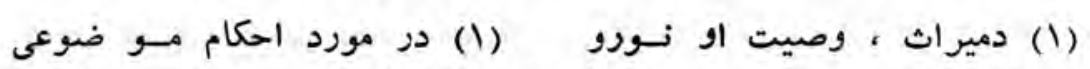

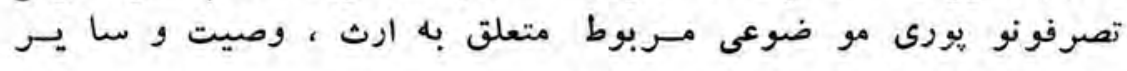




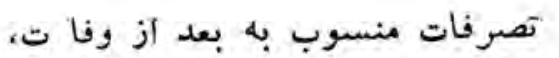

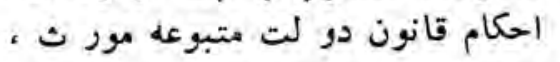

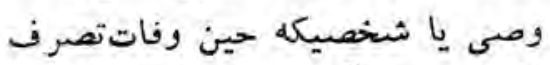

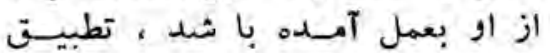

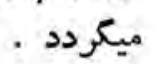

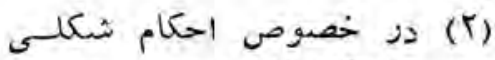

وصيت ، احكام قانون وصى دور دزحين وصيت ويااحكام قانون محليكه دزآن وصان وصني

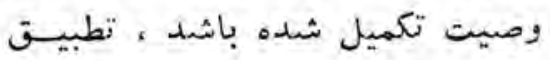

$$
\text { ميكردد . فص مد }
$$

همجــنان 1 حسكام شكلى سا ير مان

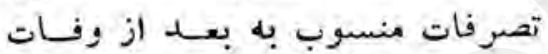

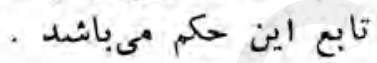

$$
\text { ماده الن }
$$

دزمورد حيازت ملكيت و سا يــ

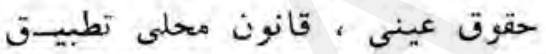

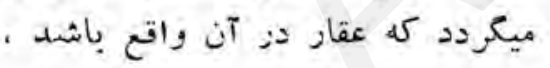
ودرمورد اموال منقول قانون محنى تطبيت هيكردد كه اموال منقول حين النول

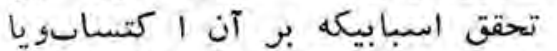

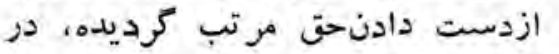
محل مذكور موجود بوده مادي است

\section{- TV ماده}

در هورد و جائب نا شيى از عقود،

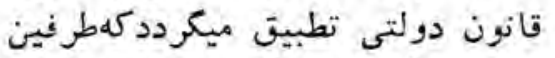

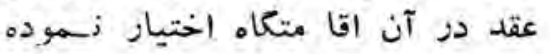
اند . . در صوزت اختــلاف اقا متكاه
حكمونه جه دمركـ خخه به وروسته

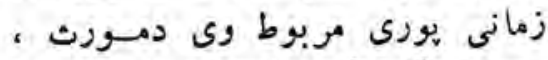

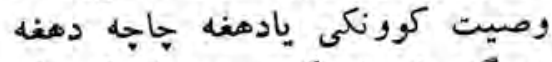

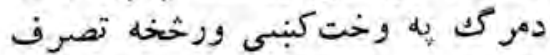

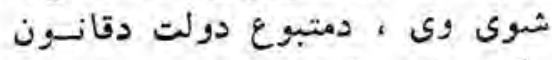
- حمونه

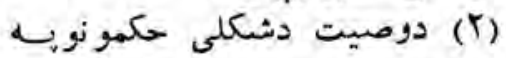

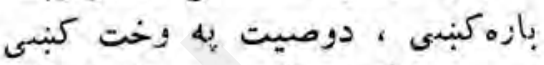
دوصى دقانون حكمونه ، ، يادمغه كخاى

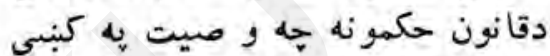

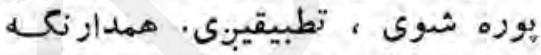

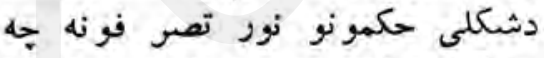

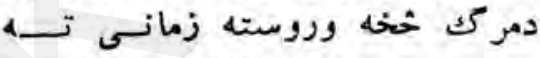
منسوب وى ددى حكم تابع دى ورو

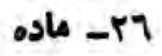

حقو

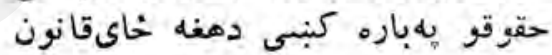

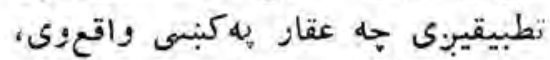

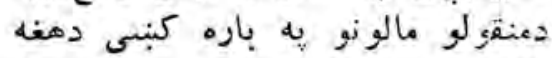

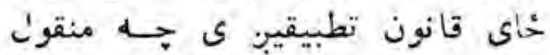

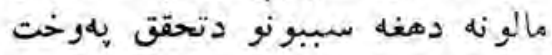

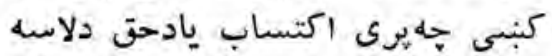

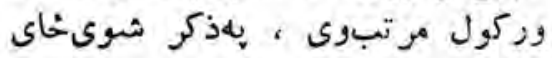

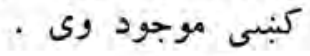

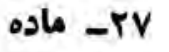

دهغه الثزاماتو لهاه باره كنيسى جه

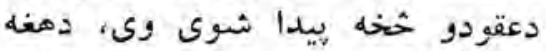

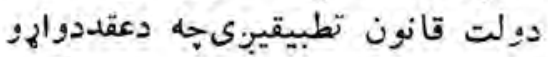

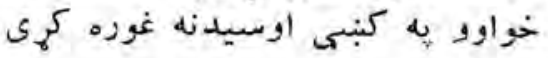




\section{sle (rq-rA)}

\section{لمرى فصل- دقانون تطبيـق}

قانون دو لتى تطبيق ميكردد كعقد

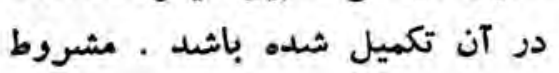
براينكه در خصوص تطبيـق احكام كدام قانون معين، طرفين عقد موافقه نه نموده باشند و و يا از قرائن معلوم نكردد كه مراد طرفين عقد تطبيـت قانون ديكرى بوده است ـ در موزد

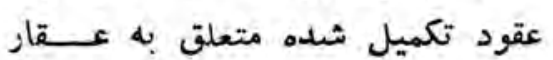
قانون محل عقار تطبيق ميكردد . - ra obla در مورد شرايط شكلى عقود،احكام قانون دولتى تطبيتق مي كردد كـــه

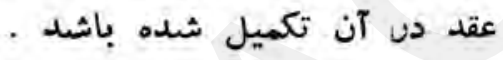

$$
\text { - ra }
$$

(1) (1) مر مورد وجائب غير تعاقدى، احكام قانون دولتى تطبيق مىكردد كه درآن حادثهاى ايجاد كننده واقع دون . شده باشد درآ حاد

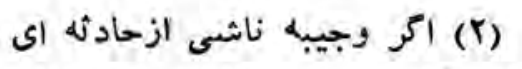

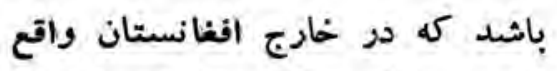
شده وحادثه در آن محل غير قانونى ودر افغانستان قانونىشناخته شوده، حكم فقره يك اين ماده تطبيق نمى
وى ، به هـغ صورت كبنى جنه

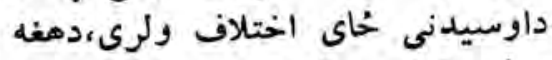

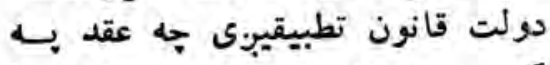

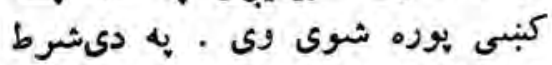

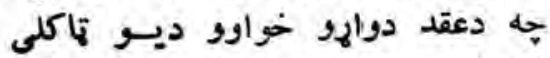

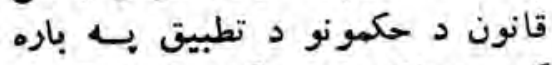

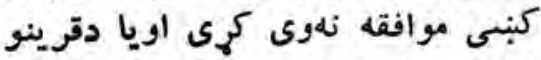

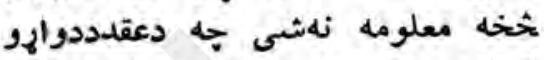

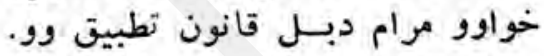

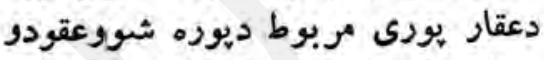

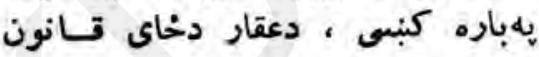
تطبيقيبزى

$$
\text { A ז- ماده }
$$

دعقو دو دشكلى شرطونو به به باره

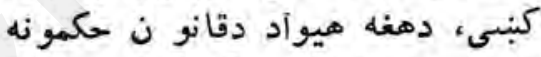

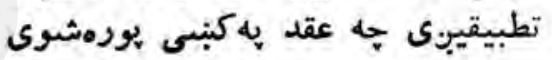
وى .

$$
\text { و פ }
$$

باره (1) دغير تعاقدى التزا مونو به دوه دون بارهكنبى ، دهغه دولـت د د قانون

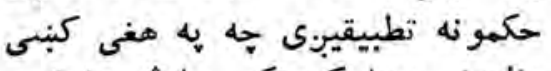

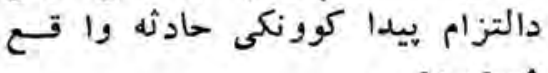

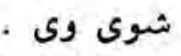
(r)

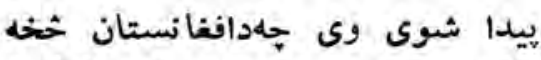
دباندى واقع شوى وى وى او حادثيانهيه

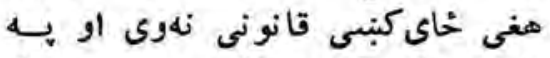

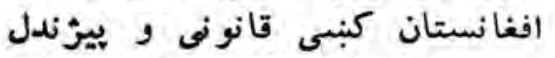

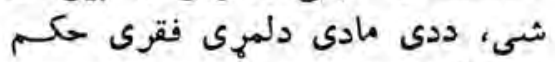
- نه تهبيقيبين دوى 


\section{ماده}

دومورد قواعد اختصاصى و تمام

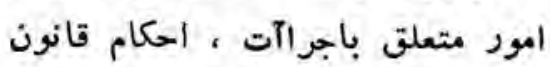

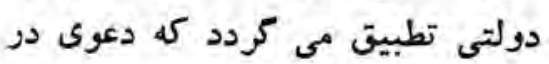

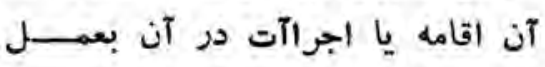

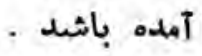

\section{- rاده}

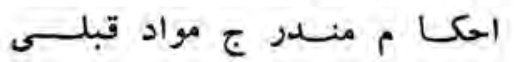
اين قسمت در صورتى نافذمىباشد، كه مخالف آن حكم ديكرى در قانون

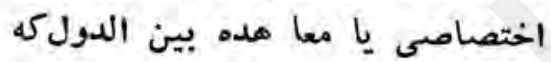

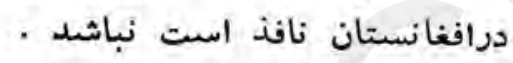

ماده

هركاه درمورد تنازعقوانين مادهمى درمواد قبلى اين قانون موجودنباشلد،

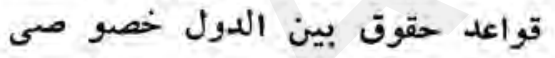

$$
\text { تطبيق مي كردد . }
$$

تعيين قائون واجب التطبيق د در مورد اشخاصيكه تابعيت شانمعلوم واجي

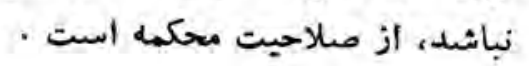

\section{ماد}

درموارديكه تطبيق 1 حكام قانون خارجى يّش بينى شده است ، آن

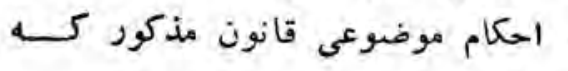

\section{r.}

داختصاصى قاعدو به باره كبنسى

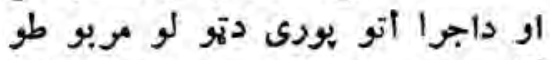

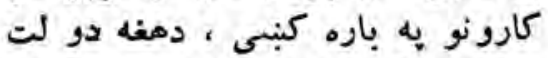

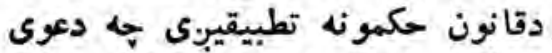

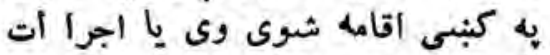

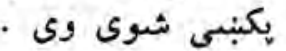

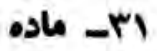

ددى قسمت لـورتنى دزج شوى مكون

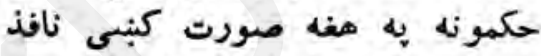

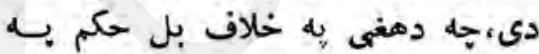

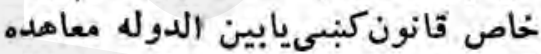

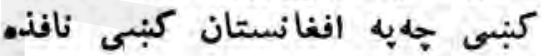
وى موجود نه وى .

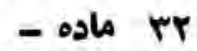

كهد قوانينو دتنازع به بهاوه بكني ددى قانون يه يورتنيو ما دو كوني كوم حكم بيدانه شيى، دبين الـدون

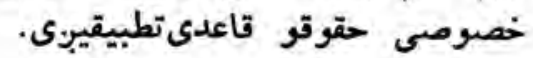

$$
\text { rra }
$$

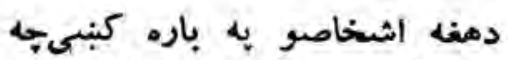

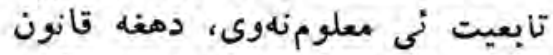

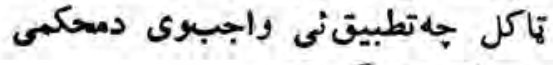

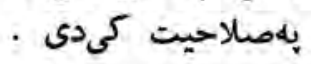
ع ع- ماده يه هغى مواردو كنبنىجه دباندنيو هيوادونو دقانون تطبيت بيش بينى بينى شوى دى، دذكر شوى قانون هغنس 


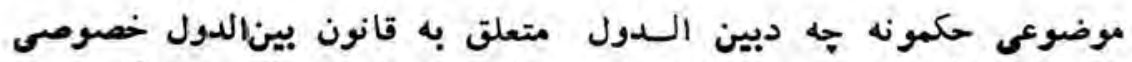

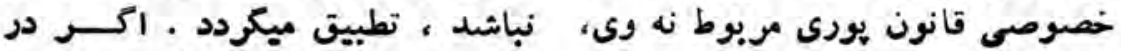

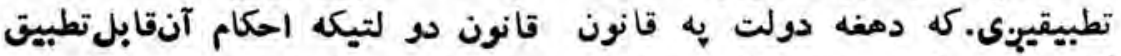

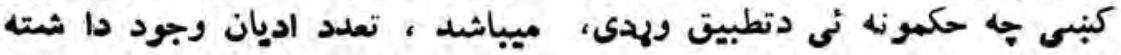

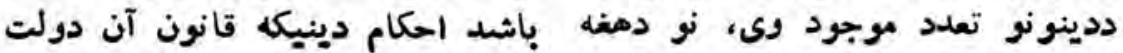

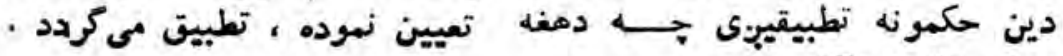
- ro مادم

احكام قانون خارجى به نحويكه

درمواد قبلى اين قسمت تصر يـــــ كرديده ، در حــدو دى قابـل تطبيق مع.شاشد كه مخالف نظامعامه يآداب عمومى در افغانستان نباشد .

أنمل وصم

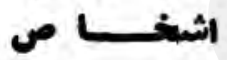

قســــــ أول

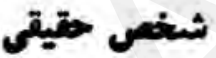

مبحث اول - احكام عهومى - ماده

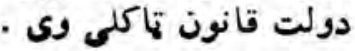

$$
\text { oro }
$$

د باندنى ميواد دقانون حكمو نه

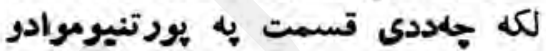

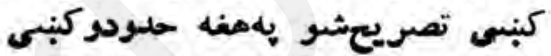
دتطبيق وم دى،جهيه تصريه افغانستان كبنى دعمومى نظام يا عمومى آدابو مخالف نه وى . نوع نغل

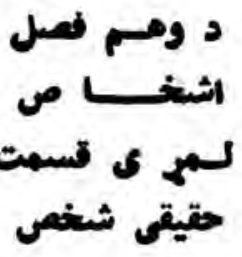

لهرى مبحث - عهوم حكهونه

$$
\text { or }
$$

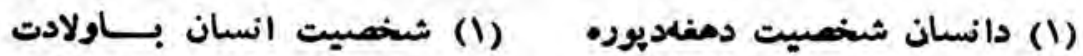

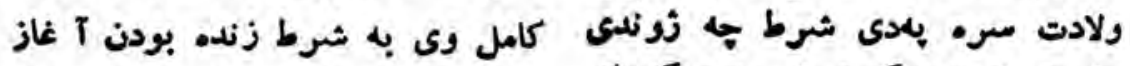

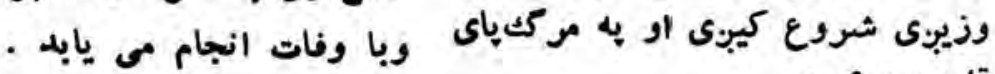
ته رسيب:ى نه كان (r) جنين داراى حقوقى مى باثل كعقانون بو آن تصريح نعودهاست. - Vr osl

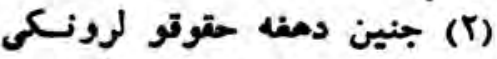

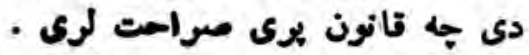

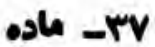

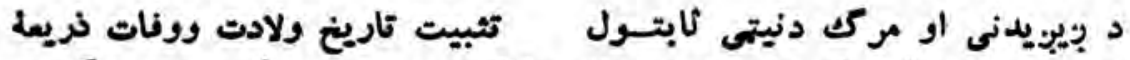

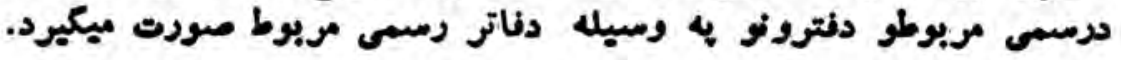




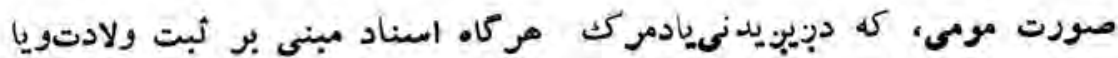

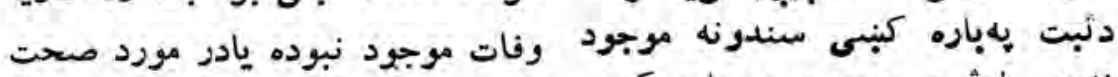

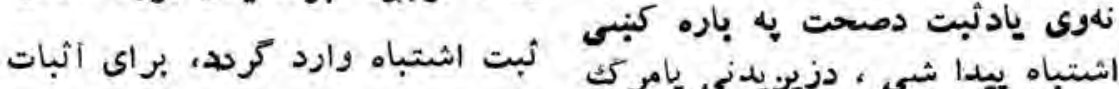

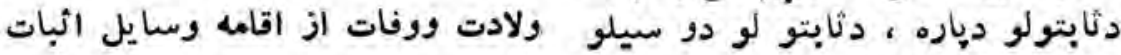

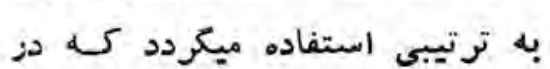
قانون تصريح شده باثد . - ra ola

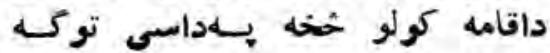

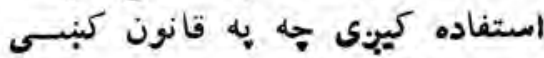
تصريح شوى وى مادئ Ar- ماده

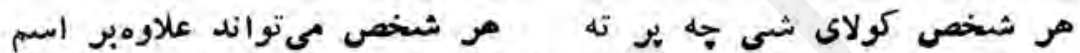

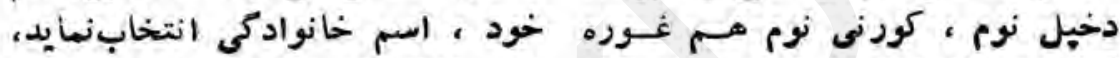

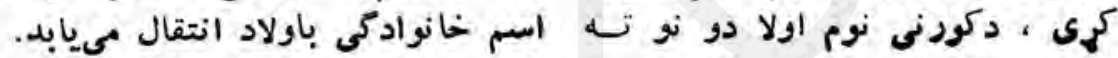

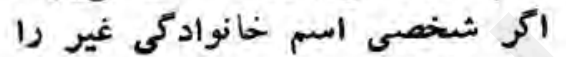

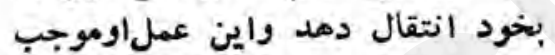

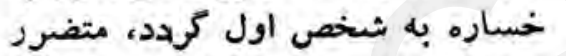

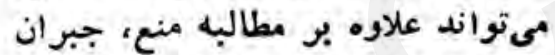

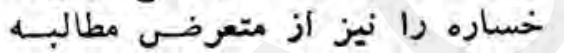

\section{- ra}

نمايد . نماره

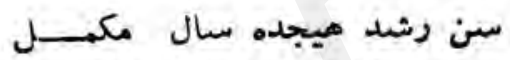

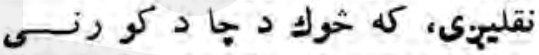

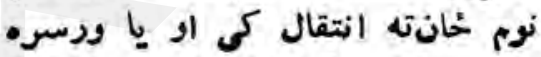

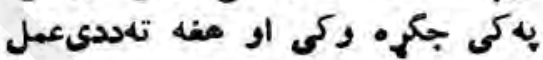

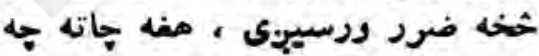

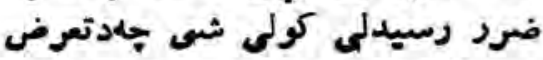

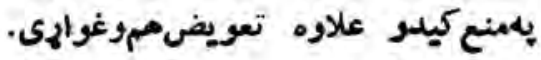

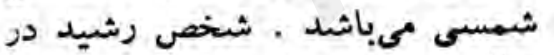

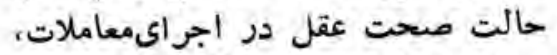

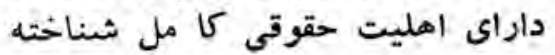

$$
\begin{aligned}
& \text { مى شود . } \\
& \text { ماده . ماد }
\end{aligned}
$$

$$
\text { ونr- ماده }
$$

درشد عمر يوره اتلس شمسيهى كلونه

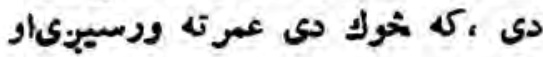

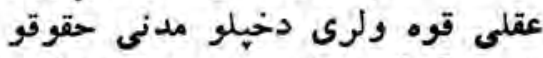

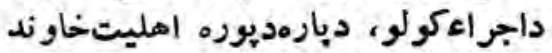
كنل كيبرى •

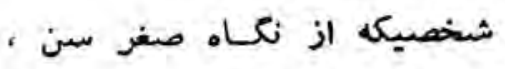

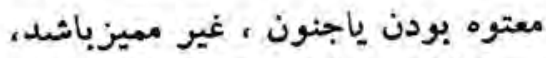

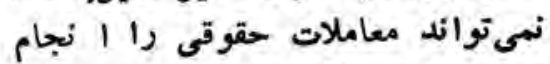

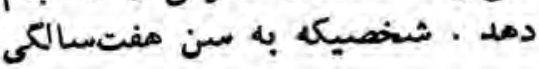

كهخور دعمر دكموالى • يامعتو. والى، ياليونتوباله امله مميزنهوى، نهثى كولى جه حقوقى معاملى تس 
نرسيده باشد غير مهـيز محسو ب

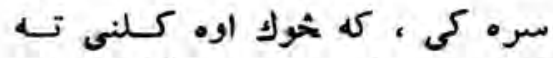

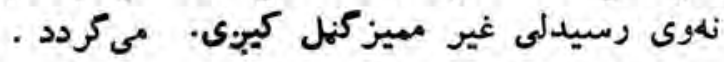

\section{ماده}

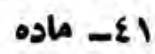

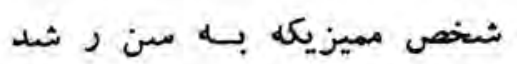
نرسيده يا اينكه به سن رشدرسيده به بهن

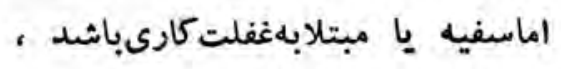

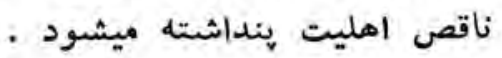

$$
\text { - Er }
$$

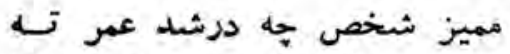

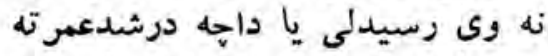

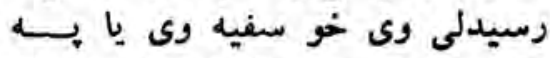

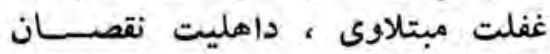

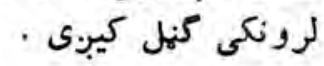
ماده

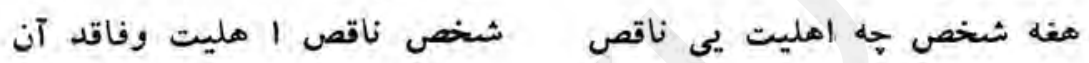

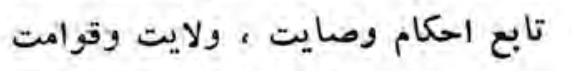

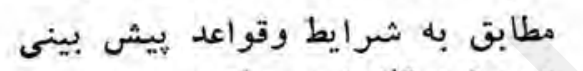

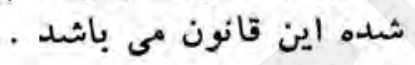

\section{ماده rع - مان}

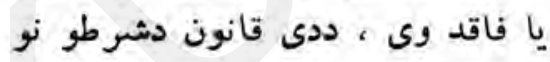

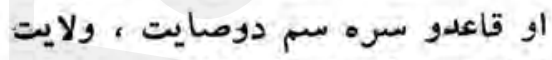

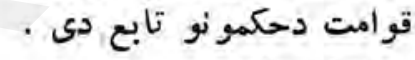

هيجكس نمى تواند از 1 هليست

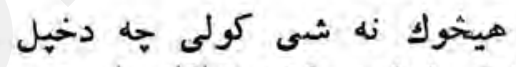

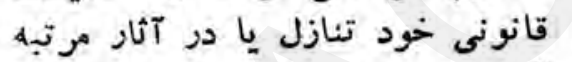
آن تعديلى وارد نمود تمايد

\section{ماده}

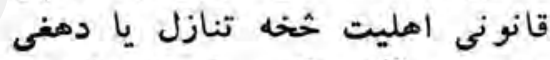

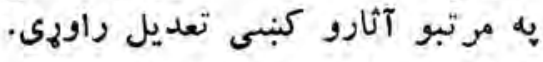

آزادى حـت طبيعى انسان است،

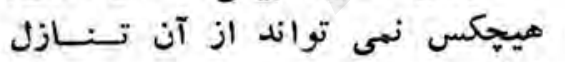
نمايد . نمادي

\section{- Eo ماده}

آزادى دانسان طبيعى حـت دى مئ

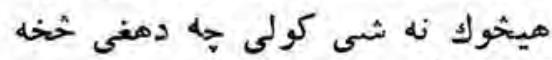

شخصيكه حقوق شخصى او مورد تجاوز قرار مى كيرد ، مىتواند علاوه برمطالبه منع تجاوز در صورت وقوع ضرر طالب جبران خساره كردد . - تنازل وكرى نه

$$
\text { ع ع- ماده }
$$

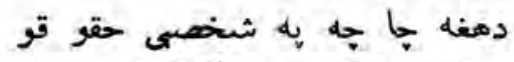

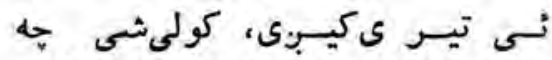
دتيرى دمنخ نيوى به غونيه غوبنتيه علاوه

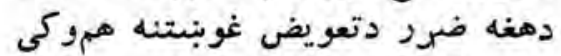

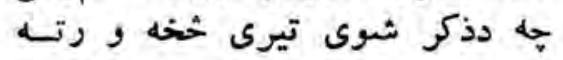
• رسيدلى دى دو 
لبهى قسمت - حقيقى شخص

$$
\text { دوهم مبحث ماده مدنى حالت }
$$

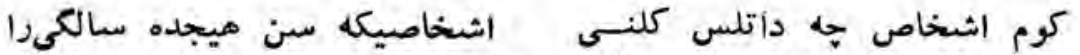

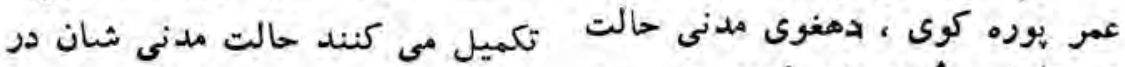

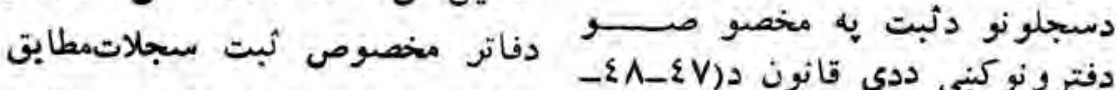

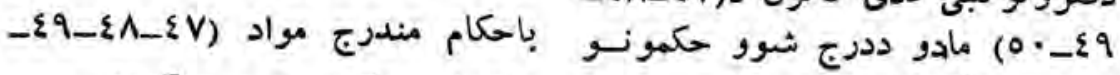

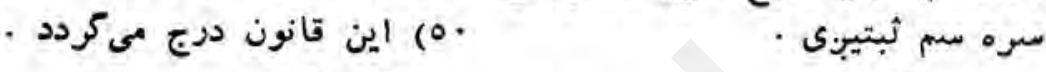

$$
\begin{aligned}
& \text { - EV ماده }
\end{aligned}
$$

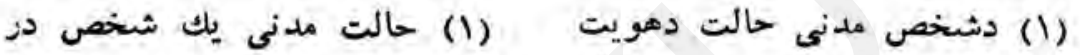

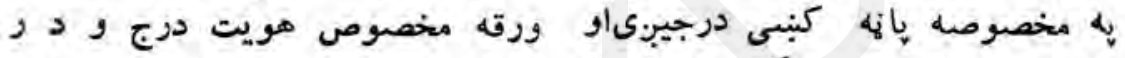

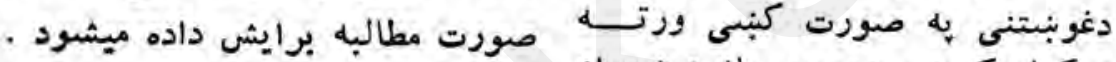

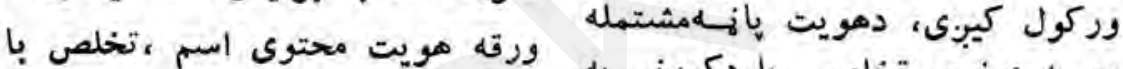

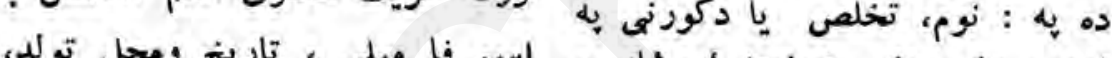

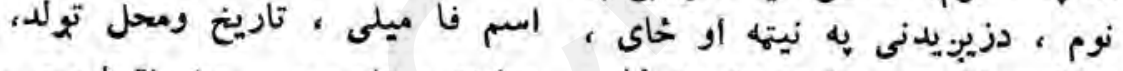

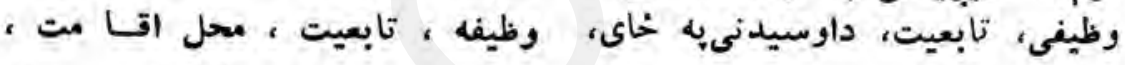

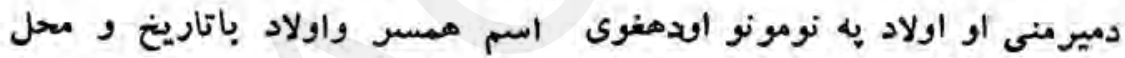

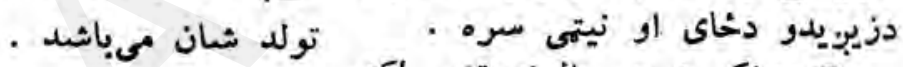

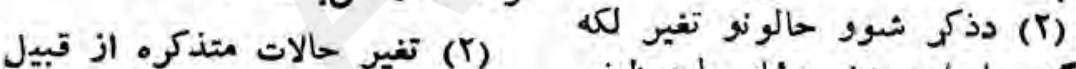

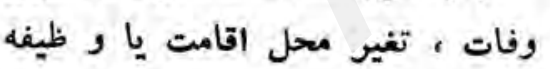
نيز در ورق هويت درج مىكردد . -

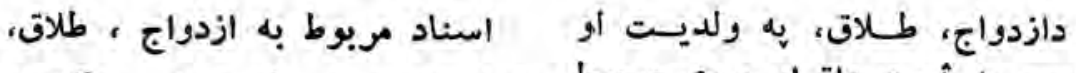

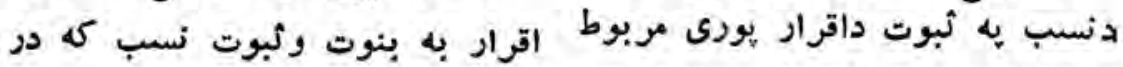
مراجع اختصاصى تو تيب مىكردد،

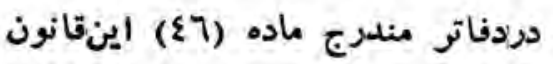
به ثبت ميرسد مراجعموصوفرسمكلف ماده

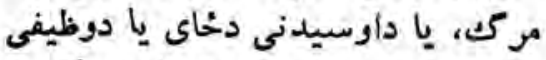

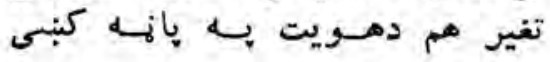
درجيبنى ^£- ماده

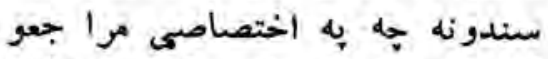

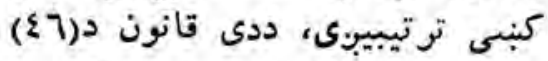

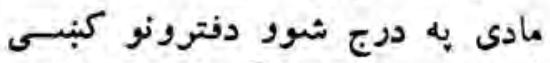

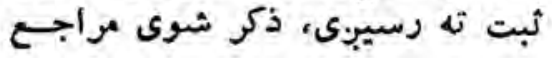




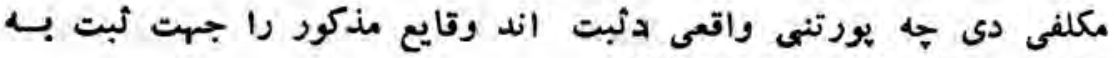

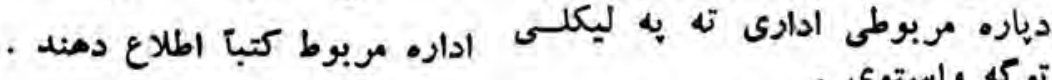

\section{- El -} توكه واستوى مرئ

خارنوال مىتواند از جريان

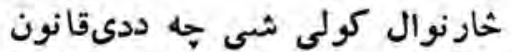

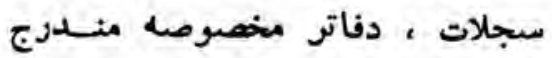

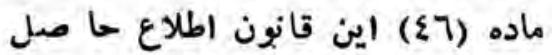

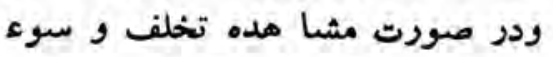
اجرآت به اقدامات قانونى بيردازد.

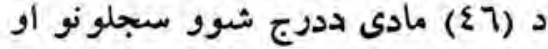

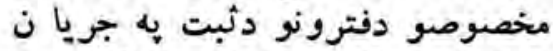

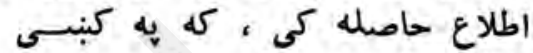

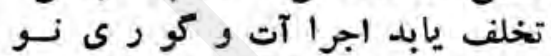
قانونى اقدام به كوى آنرا o 0 -

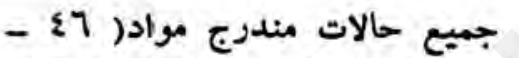

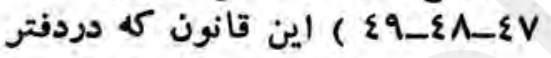
مخصوصثبت سجلات ياتذكرهنفوس

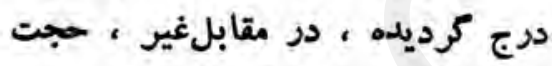

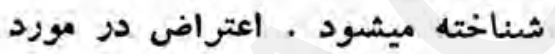
همجيو اسناد مجاز نيست، مكراينك اعتراض بر جعليت يا تزوير اسناد

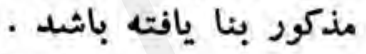
مبحث موم - مان اقا متكــاه ماده

(1) اقامتعاه جا ييست كهشخص عادتآ در آنسكونت دارد ، خواهاين سكونت دايم يا موقت باشد . (T) شخص مى تواند بيش از يك

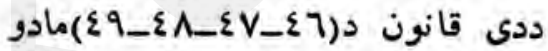
تول درج شوى حالونه جيه دسجلونو

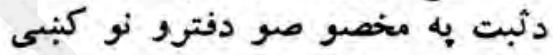

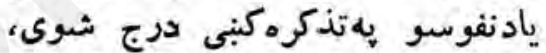

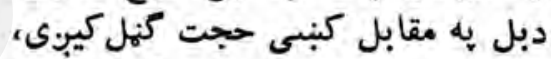

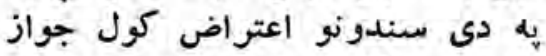

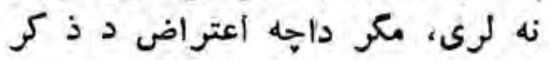

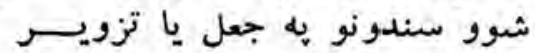

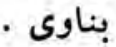

$$
\text { دريم مبحث - داوسيدنق محاى }
$$

(1) داوسيدلو خا ى هغه دى جه

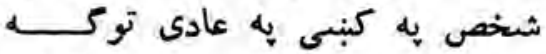

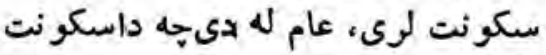
دايمى وى يا موقت لري، عام لدون.

(r) يو شخص كولاىشى جهديو خخه زيات داوسيدلو خايونه ولرى. اقامتكاه داشته باشد . 


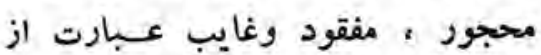
اتامتكاه قايممقام قانونىشانميباشد.

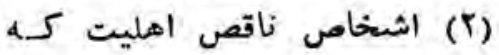
مججور، هفقود او دغايب داوسيد لوني لو دوني

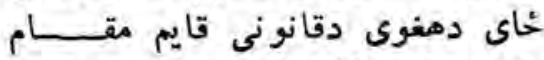

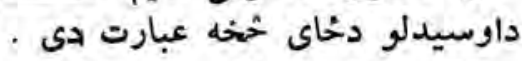

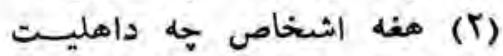
ماذون به تجارت باشيند، مىتواثند

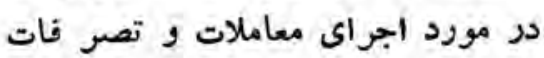

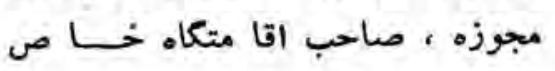

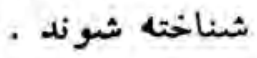

$$
\begin{aligned}
& \text { ماده }
\end{aligned}
$$
نقصان ولرى او دتجارت كولو اجازه

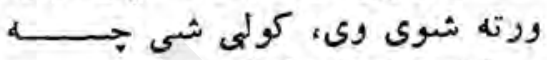

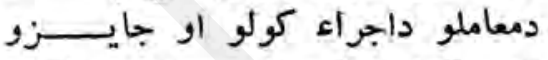
تصر فونو دياره داو سير كولد نى دي دخاص

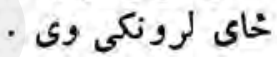
or or

جائيكه شخص در آنه تجها

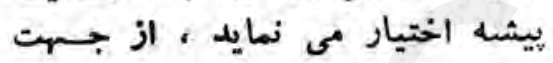

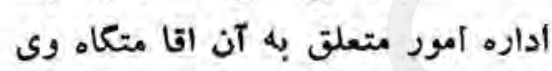

$$
\begin{aligned}
& \text { شناخته مى شود ادور متعلي له آن } \\
& \text { ماده }
\end{aligned}
$$

(1) يك عمل معين قانونى اقا متكـــاه

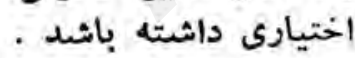

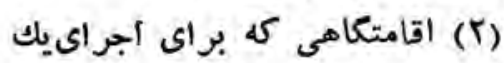

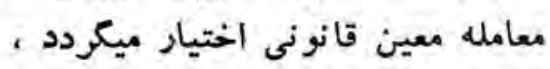

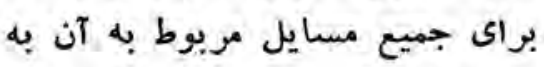

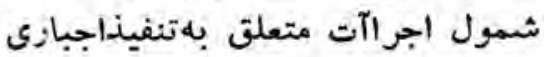

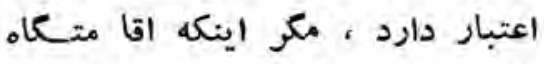

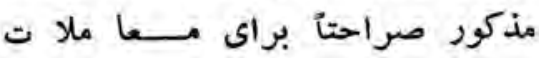

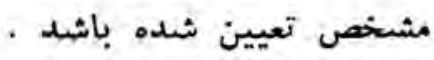

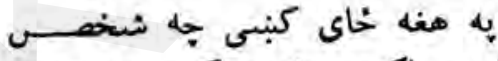
تجارت ياكسب غوره كوى ، دمغسي

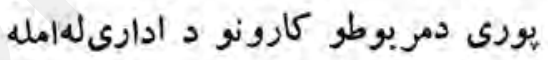
دهغ داوسيدلو خاى كنل كيبنى \& (1) شخص كولا ى شيى ديوتاكلى مادل

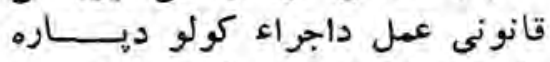
داوسيد لو اختيارى خاى ولرئ دولو دول

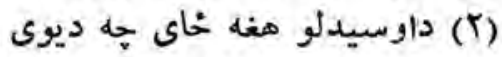

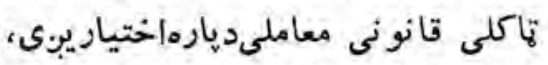

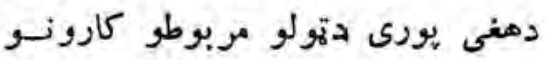

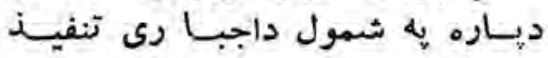

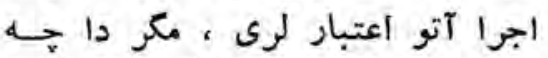

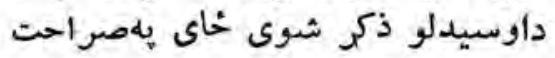
سره دمشخصو معا ملو دياره هاكل شوى دى دمثره 
(r) البات اقا متكاه 1 ختسيانى

بدون اسناد كتبى جواز ندازد .

$$
\begin{aligned}
& \text { مبحث حارم - تابعيت } \\
& \text { ماده }
\end{aligned}
$$

تابعيت افغانى توسط قانون ماهن

$$
\begin{aligned}
& \text { تنظيم مى كردد . تابع افن } \\
& \text { مبحث بنجم - فا ميل } \\
& \text { - } 07 \text { ماده }
\end{aligned}
$$

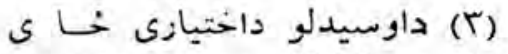

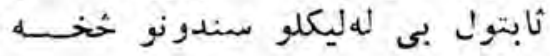

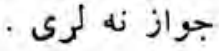

$$
\text { خلوم مادم مبحث - تابعيت }
$$

افغانى تابعيت دخاص قاده

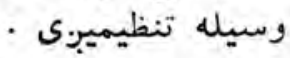

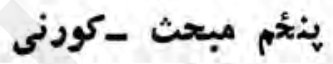

$$
\begin{aligned}
& \text { 70- ماده }
\end{aligned}
$$

دانسان كورنى دهغه خهيلو انهو

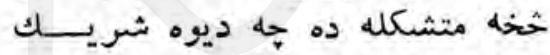

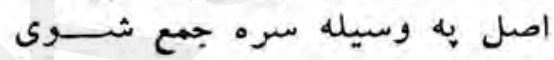

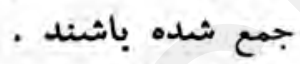

$$
\begin{aligned}
& \text { - ov ماده }
\end{aligned}
$$

$$
\text { مادم }
$$

مستقيمه خهلوى داصل اوه اوه فرعى

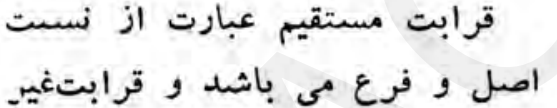

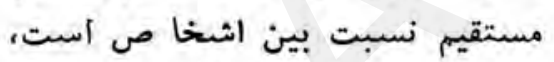
كه دازاى اصل مشترك بوده بدرن

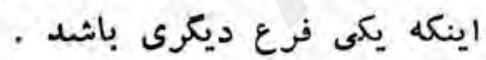

$$
\text { ماده }
$$

\section{(1)}

مستقيم از فرع به اصل ، هر فرع يكدرجه شنا خته شده و خود اهل

درين محاسبه شا مل نمى باشد .

(r) در محاسبه درجه قــرا بت بت

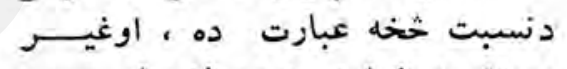

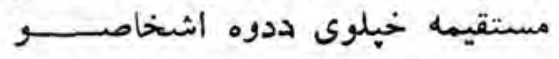

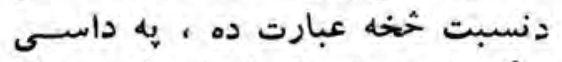

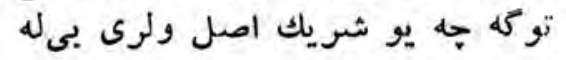

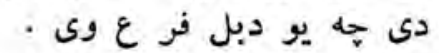

$$
\text { 1) ماده }
$$

بها

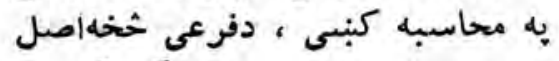

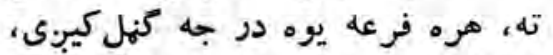

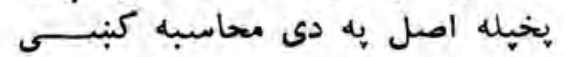
شامل نه دى ديله اصن

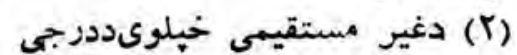

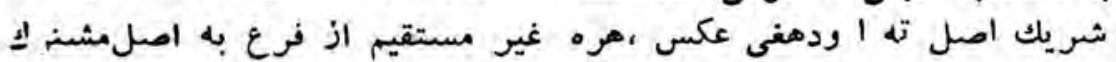




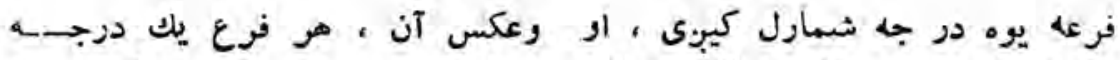

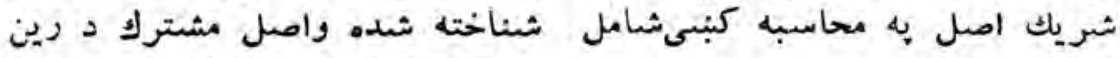

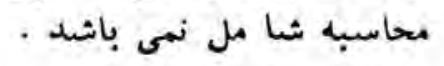

$$
\text { - } 09 \text { مادم }
$$

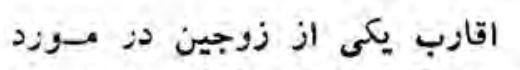

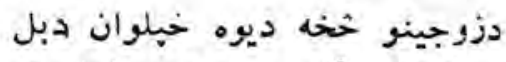

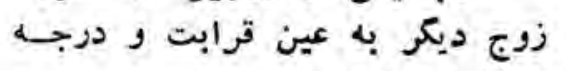

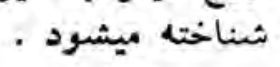

$$
\begin{aligned}
& \text { مبحث ششم - ماخد مدود ماج } \\
& \text { ماده مبدم }
\end{aligned}
$$

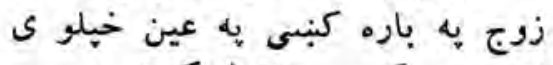

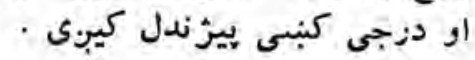

$$
\text { شبرم مبحث- ازدواج }
$$

$$
\text { ه } 7 \text {. }
$$

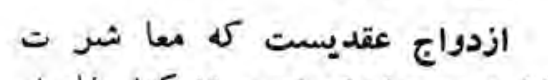
زن ومرد را به مقصد تشكيل فئ فاعيل

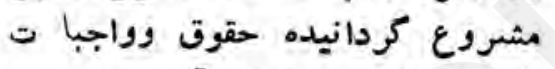

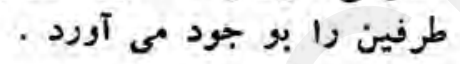

$$
\text { - } 71 \text { osh }
$$

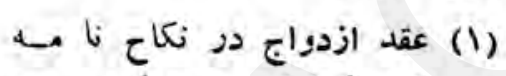

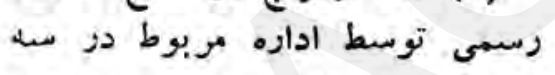

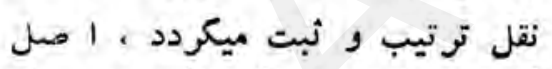

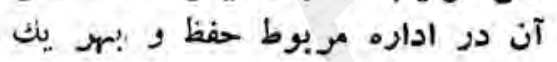

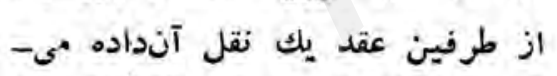

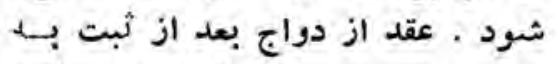

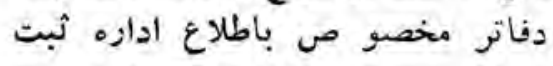

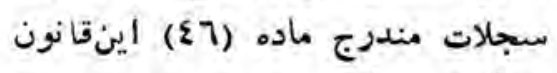

$$
\text { رسانيده ميشود ميندر ماتوه }
$$

تر تبر (r)

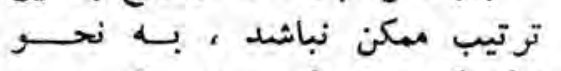

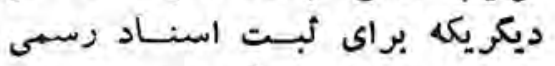

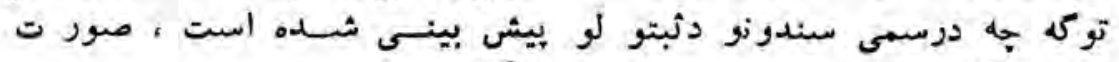

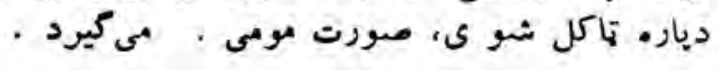


- Ir ol

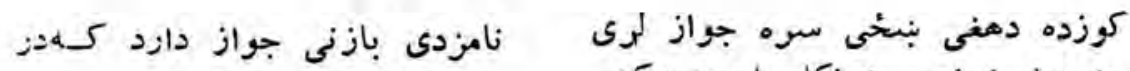

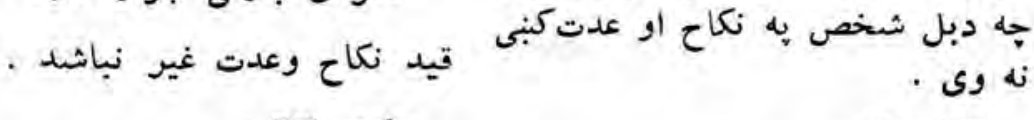
- Th

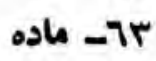

خواستعارى زن در عدت طداه

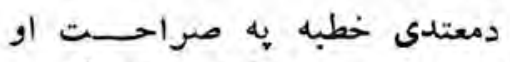

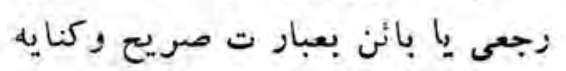

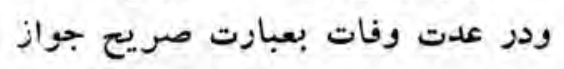

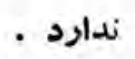

\section{- IE}

نامزدى عبارت از وعده أحه به ازدواج

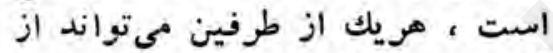
آن منصرف شود الت مرد - 70 ماد مند هركاه نامزد به نامزد خودهدية

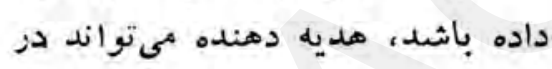

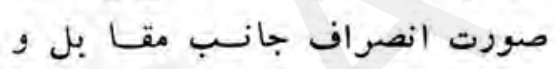

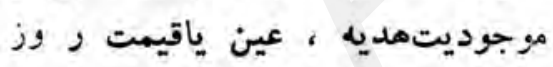

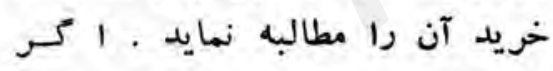
انصراف از طرف هديهدهندهصرئ بكيرد ياهديه ملاك و و يـا استهالك

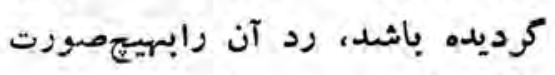

$$
\begin{aligned}
& \text { مطالبه كرده نمى تواند . مادهد ردو } \\
& \text { ماده }
\end{aligned}
$$

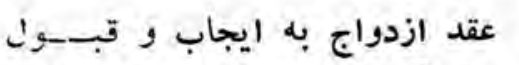
صريح كه فوريت واستمراروا افنابد

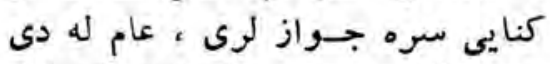

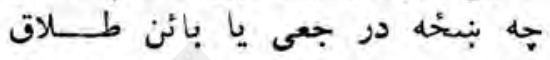

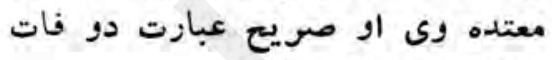

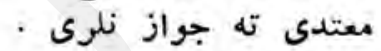

$$
\text { - ع }
$$

كوزده دازدواجدوعدى هخهد عبازه

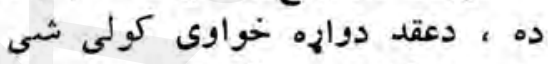

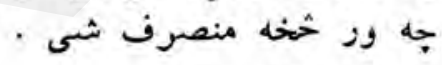

$$
\text { o }
$$

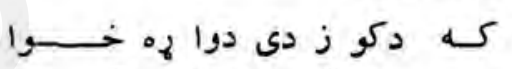

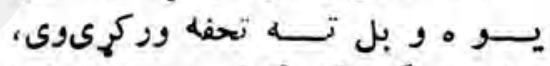

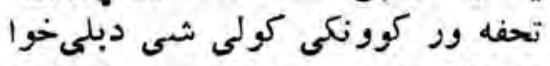
دعدول يه صورت كورت كبنى عين

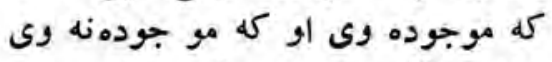

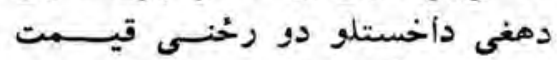

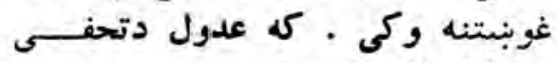

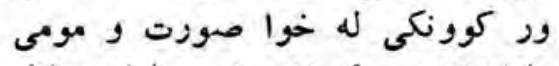

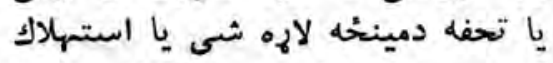
شوى وى، دمغسى بير ته اخستلهيه

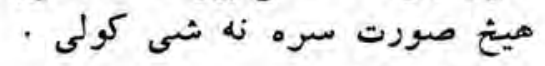
واد 79

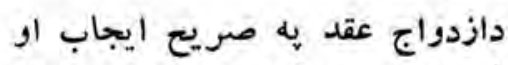
قبول سوه جه فوريت او إو استمرار إبها 
مادى (VI-TV)

كند بدون قيد وقت دز مجلس واحد

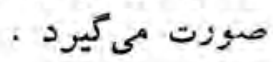

- IV

ازدواج دن صورت تعليت آن بـه

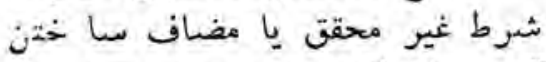
آن بزمان آينده عقد شيده نميتوافئد

$$
\text { ماده }
$$

هر كاه دز عقد ازدواج شر طــــ

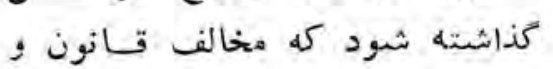

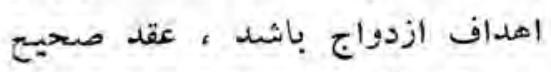

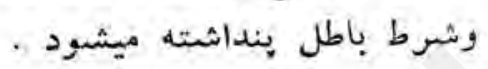

$$
\text { - } 79 \text { ماده }
$$

دز عقد ازدواج بدل ، زن ، بـل

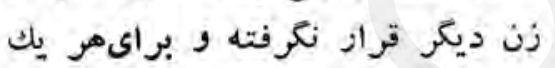
از زوجه ما مهر مثل لازيم مى فيردي.

$$
\text { - V. }
$$

اهليت ازدواج و قتسى كاملمى كـ

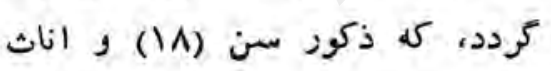
تحانزده سالكى زاتكميل كردهباشند.

$$
\text { - VI ماده }
$$

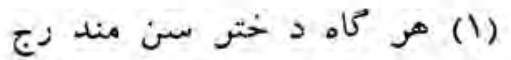

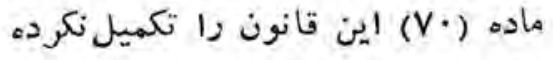
باشد ، عقد ازدواج وى تنها توسط

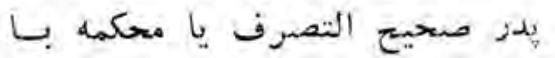

\section{لممى قسمت - حقيقى شخص}

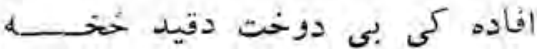

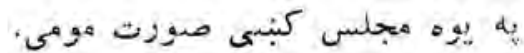

$$
\text { Vآ- ماده }
$$

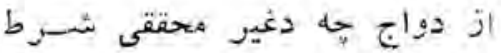

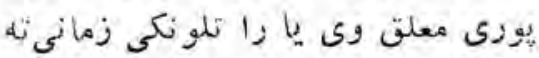

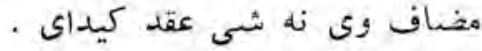

$$
\text { 1 }
$$

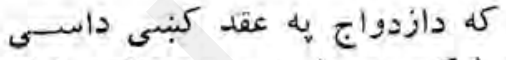

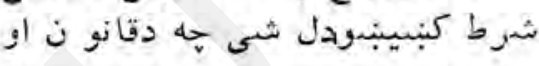

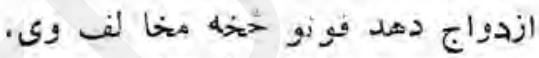

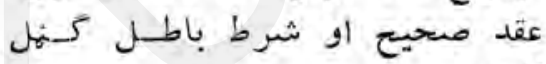

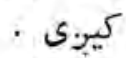

$$
\text { ون } 79
$$

دبدل ازدواجيه عقدكبى يوه بندئه

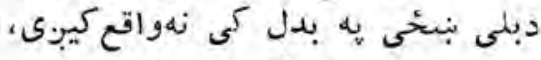

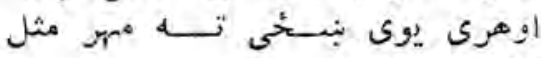
لازميبِي

$$
\text { ماده }-V \text {. }
$$

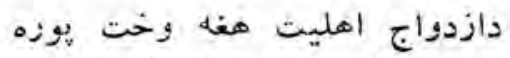

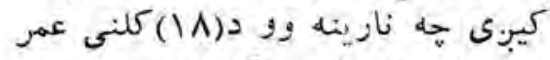

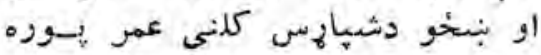
·

$$
\text { -VI }
$$

(V·) 2 ( 4 (I)

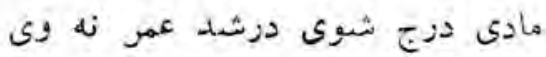

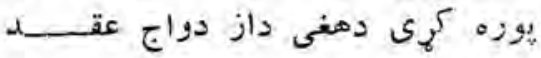

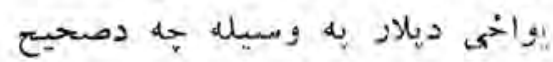




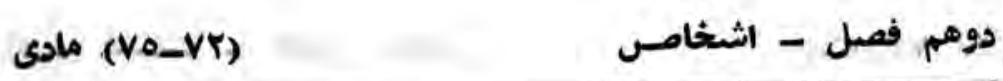

صلاحيت صورت كرفته مى تواند .

تصرف لرونكى وى يا دصلاحيـت

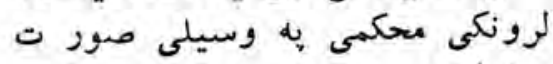

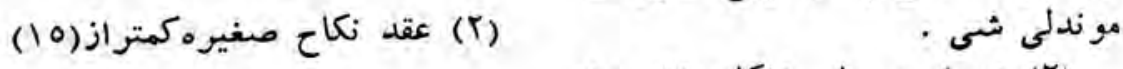
جا

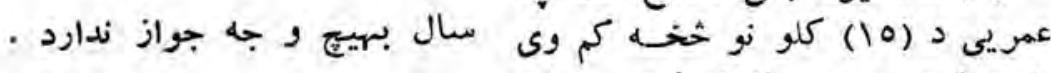

$$
\text { - vi or }
$$

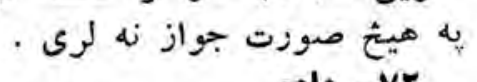

$$
\begin{aligned}
& \text { r - V - r }
\end{aligned}
$$

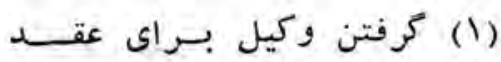

$$
\text { ازدواج جواز دارد . الحن }
$$

(1) دازدواج دعقد دياره دوكيل

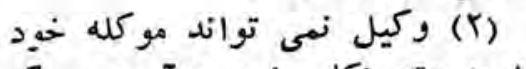

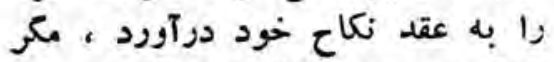
اينكه در عقد وكالت بها بهد آن تصريح

$$
\begin{aligned}
& \text { شده باشد . شعاه } \\
& \text { - vr }
\end{aligned}
$$

هو

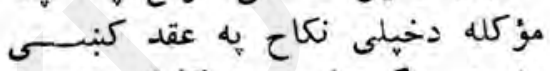

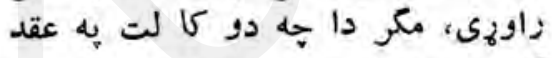

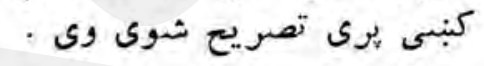
r

وكيل نمى تواند دز عقد ازدواج بدون تفويض صلا حيت يا اجـــازه موكل يا موكله خود ، شخص ديك ديكرى

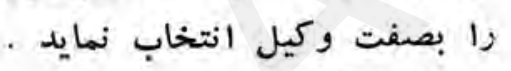

- VE ماده

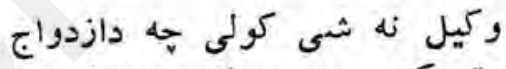

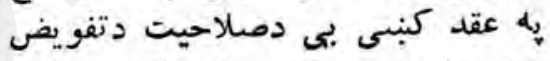

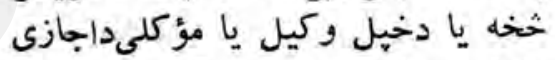
يه غير، بل شخد انتخاب كير، كل

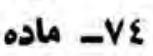

وكيل نمى تواند عملى را كه خارج

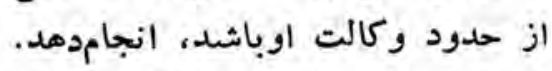
تصرف خارج از حدود وكالت بمثابه

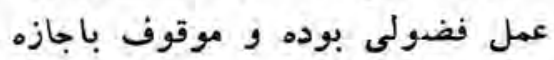
•وكل يا موكله او مى بـ باشد موقد

$$
\text { - vo }
$$

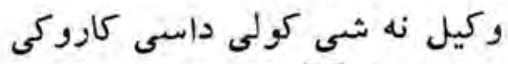

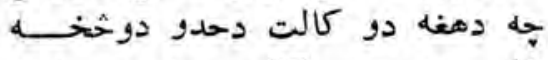

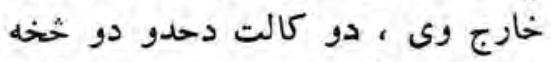

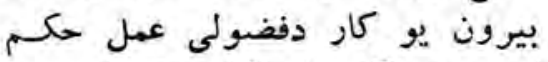

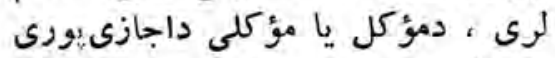
• موقوف دى دو دو ماد - Vo

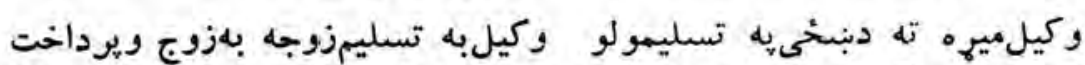

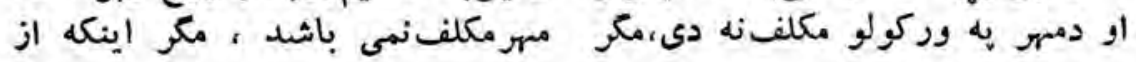


يرداخت مهر ضمانت كرده بـاثلد .

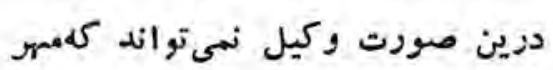
تاديه شده را از زوج مطالبه نمايد، جز دز حالتيكه ضمانت وكيلباجازه زوج صورت كرفته باثد .

$$
\text { - v1 }
$$

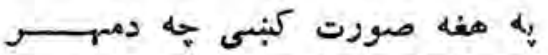

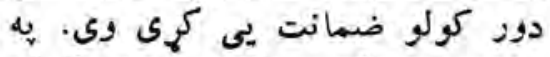

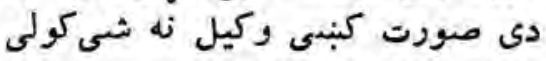

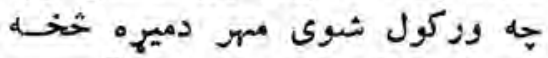

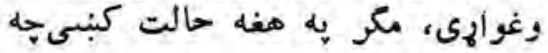

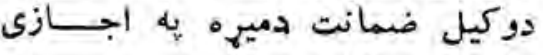

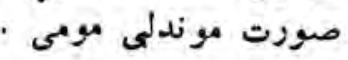
ר

در صورتيكه طرفين عقد اصالتآ. شرعآ ياتوكيلا تحت ولايت شنخصى

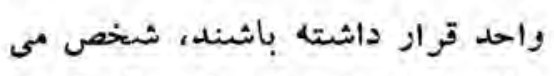
تواند به تنهانى از جانب طر فيـن

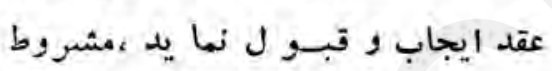

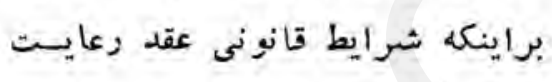

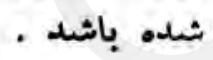$$
\text { - VV }
$$

براى صحت عقد نكاح ونفاذ آن

$$
\text { شرايط آتى لازم أست : }
$$

1- انجام ايجاب و قبول صحيع توسط عاقدين يا اولياء يــا و كالدى

$$
\text { • ثان }
$$

r- حضور دونفر شاهد بإهليت.

r- عدم موجوديت حرمت دانمى

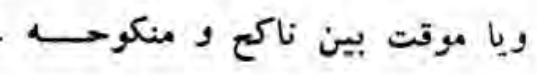

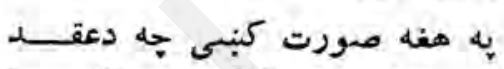

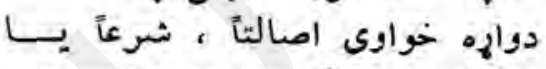

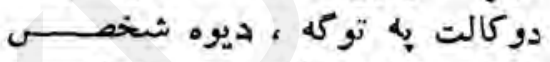

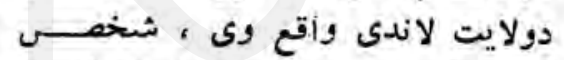

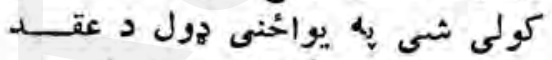

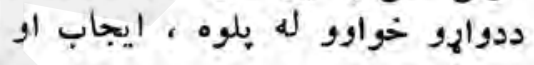

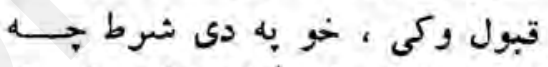

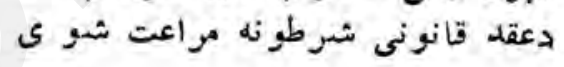
- s?

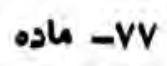

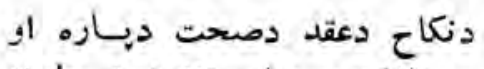

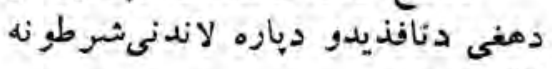
لازم دى : دمغ دنافي

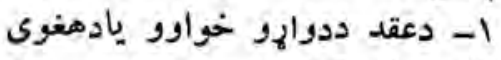

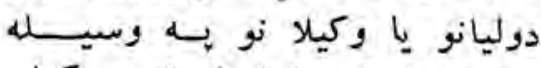

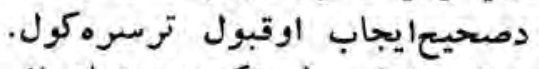
r- داهليت لرونكو دوه شاهندانو ترون

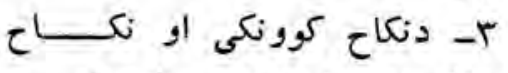

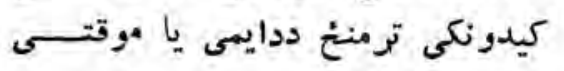
حرمت نشتوالى كئى 


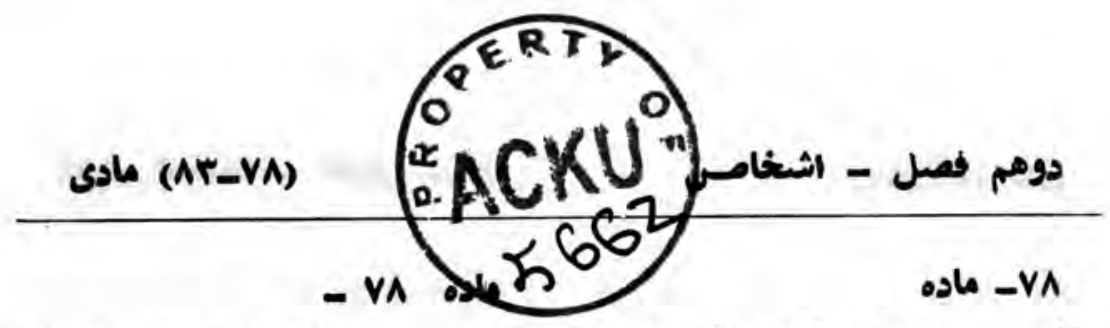

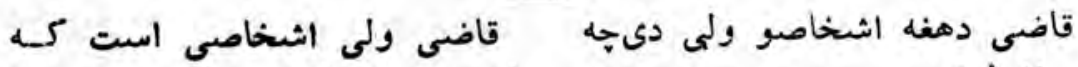

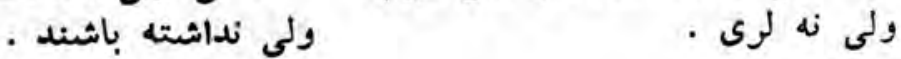

$$
\begin{aligned}
& \text { - Va ماد }
\end{aligned}
$$

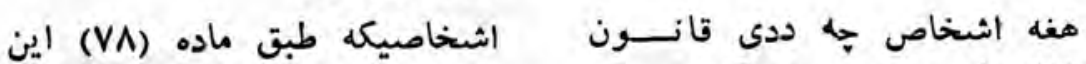

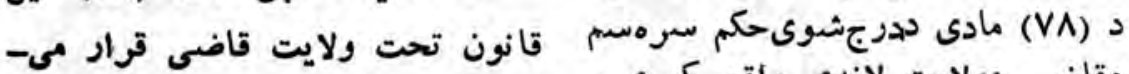

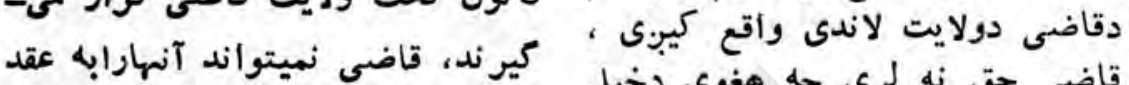

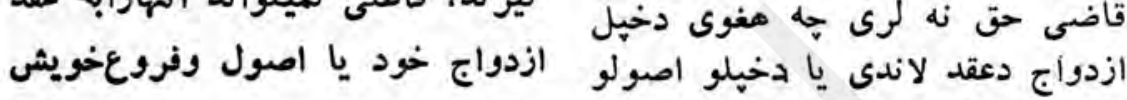

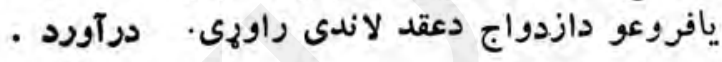

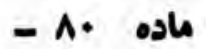

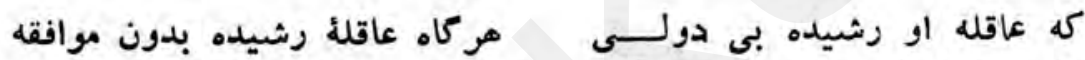

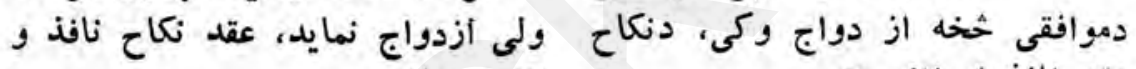

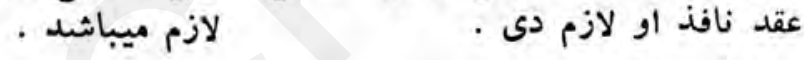

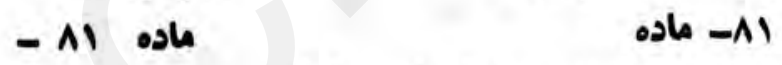

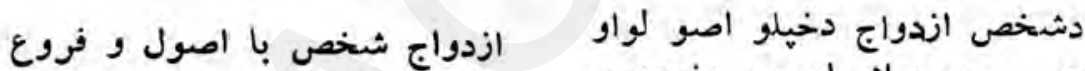

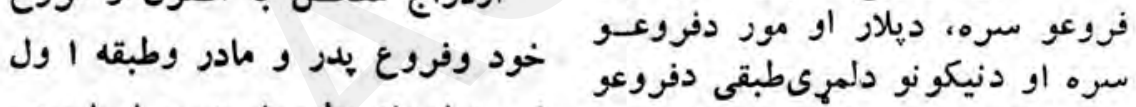

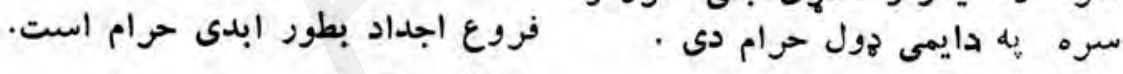

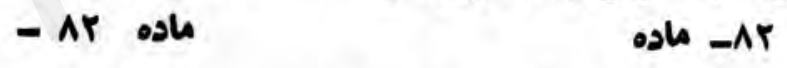

ازدواج شخص بازوجه 1 مبو ل وزوجه فروع خودش بطور دايمحرام

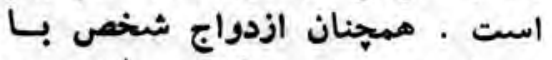

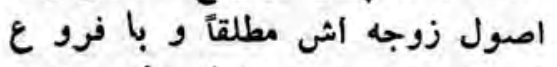
زوجه در صورت دورت دخول بطور دايـــ

$$
\begin{aligned}
& \text { حرام ميباشد . مرد } \\
& \text { ماده r ماب - }
\end{aligned}
$$

دشخص ا زدواج دخيلى بنخسى

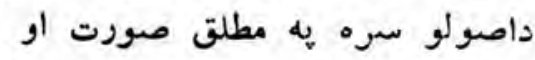

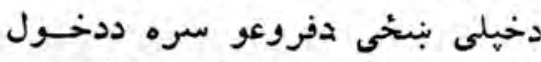

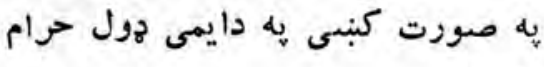

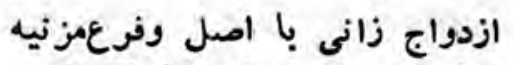

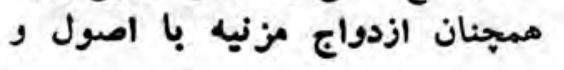

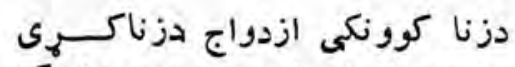
شوى داصل او فرعى سرهمهدارنكه دزي 


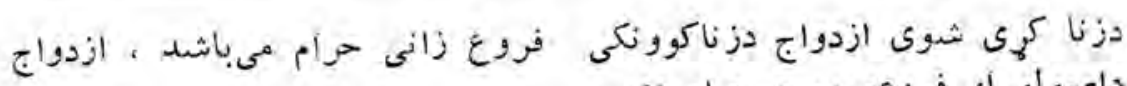

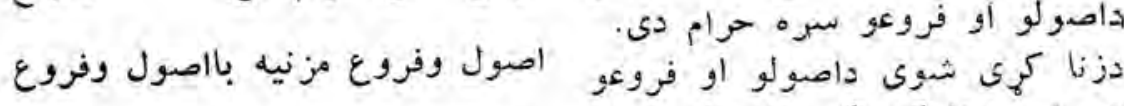

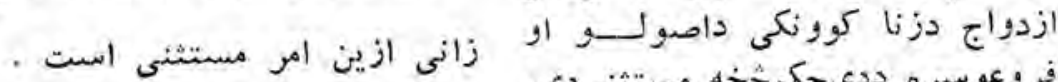

\section{- $\Lambda \varepsilon$ os}

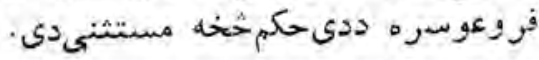

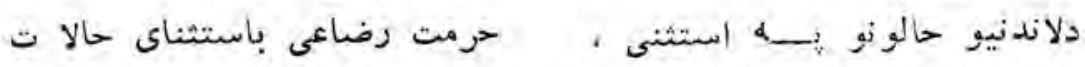

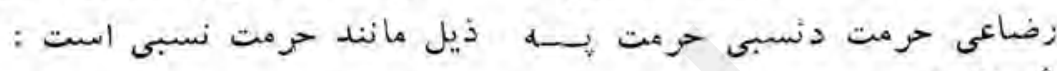

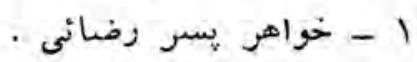

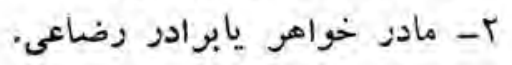

1-

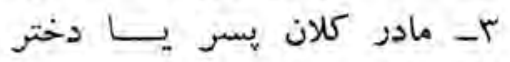

زغشاعى

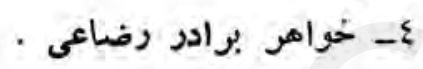

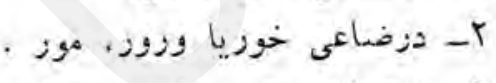

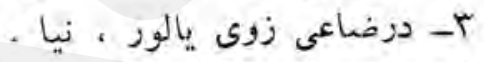

$$
\text { - } 10 \text { o }
$$ \\ - 10 oslo}

دز حالات ذيلحرمتموقتموجون

$$
\text { ميكرد2 : }
$$

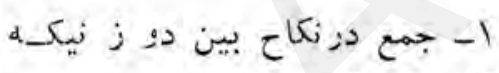

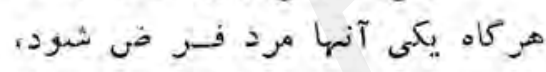

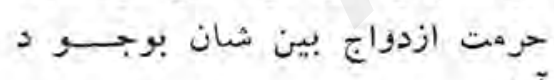

T- مطلقه ثلاثه نازمانيكه باشخص

$$
\text { ديكرى ازدواج زمايد }
$$

·

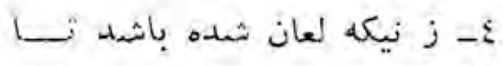

وقتيكه ،شوهر خودرا تكذيبنمايد.

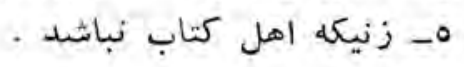

آيد.

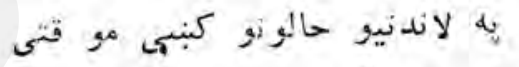

حرمت بيدا كيبوى : لدانو

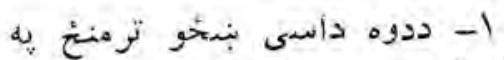

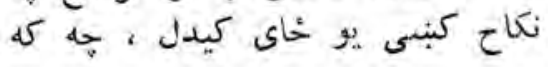

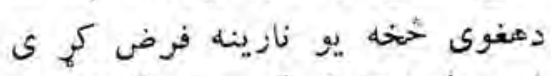

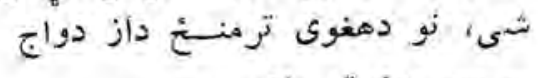

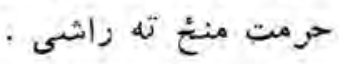

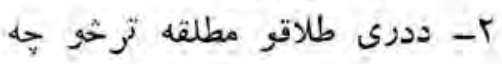

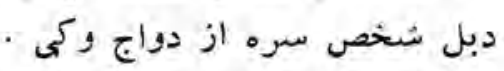

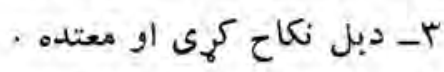

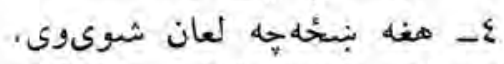

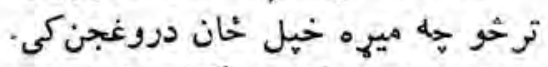

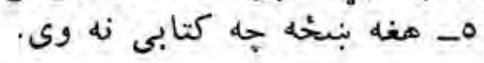




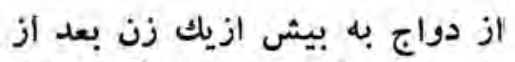

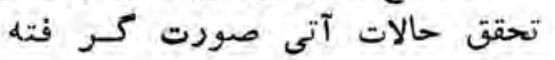
مى تواند :

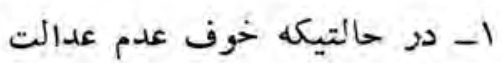
بين زوجات موجود نباشد

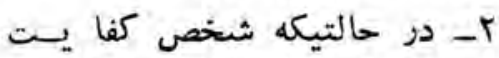

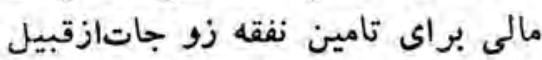

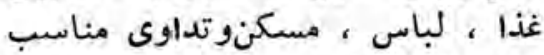

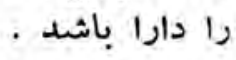

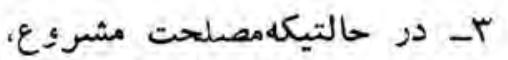

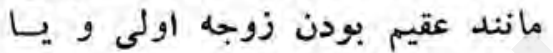

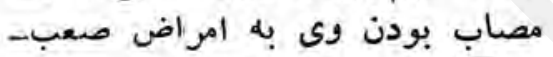

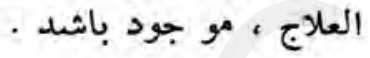
- AV ماده

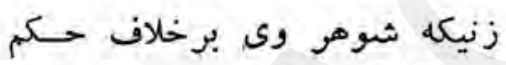

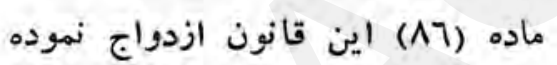

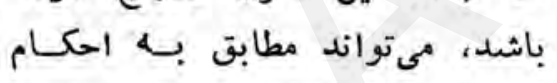

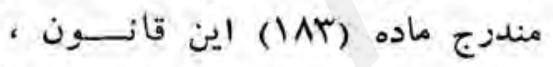

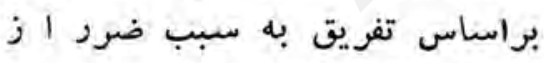

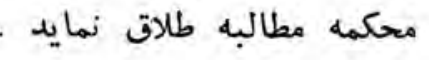

\section{ماده}

زن مىتواند هنكام عقد از دواج

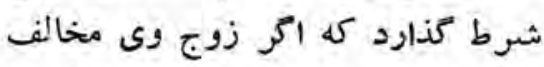

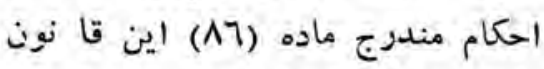

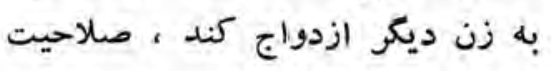
طلاق به او انتقال داده ميشود. اين إدواج
ديوى خــا دزيه دزياتو بنبخو ازدواج

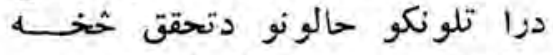

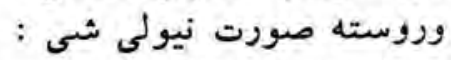

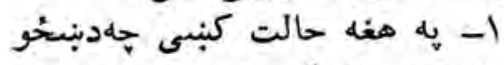
تومنيخ دبى عدالتى ويره مو هالت جينه جهوده نه وى . نومن

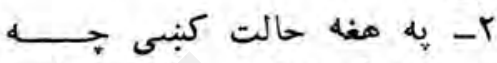
شخص دنبنخو دنفقى دتامين دياره

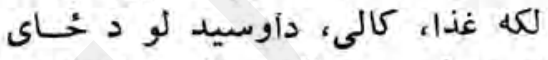

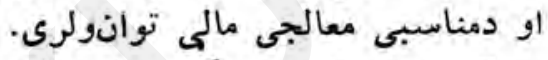

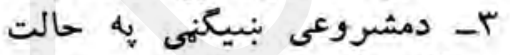

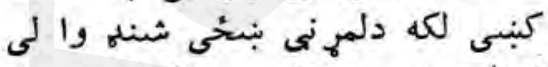

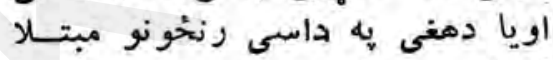

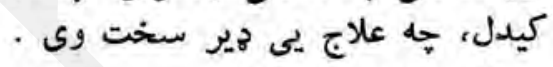

$$
\text { -AV }
$$

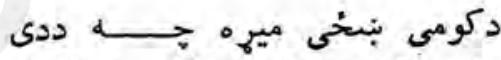

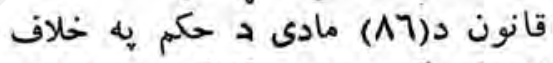

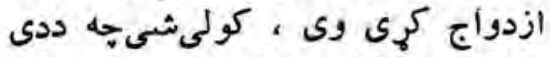

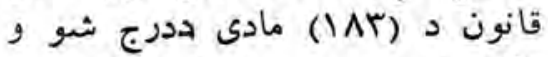

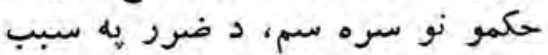

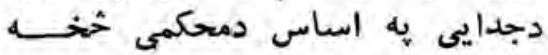

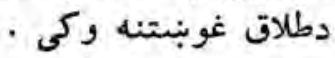

$$
\text { ه } 1 \text { A }
$$

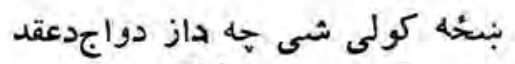

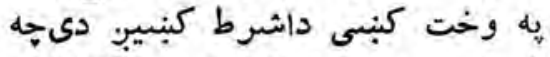

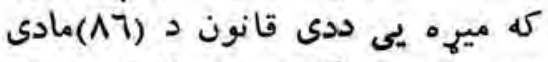

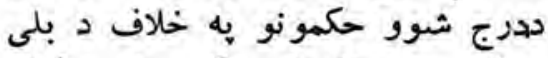

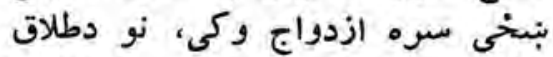

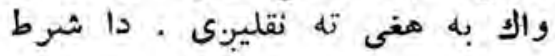


شرط وقتى اعتبار دارد كه در وثيقه

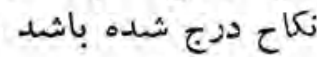

$$
\text { - } 19 \text { osto }
$$

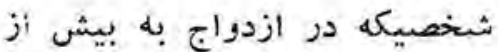
يكزنمطابق حكممندرج ماده(1)إين

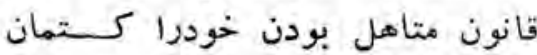

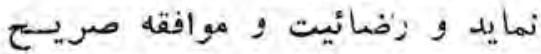

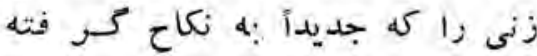

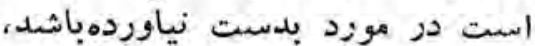
دزينصورت زوجه جديد مى توا نهد

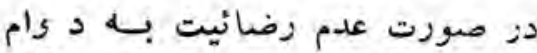
معاشرت بازوج ، مطابق بهائه 1 حكام دورام

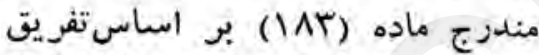

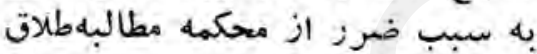
نمايد مئد

$$
\text { مبحث هفتم - آثار ازدواج }
$$$$
\text { فرع اول - احكام عمومى }
$$$$
\text { - } 9 .
$$

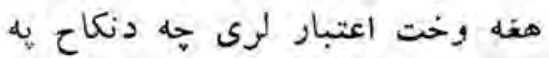

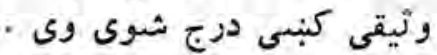
- 19

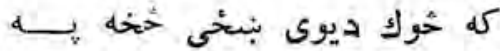

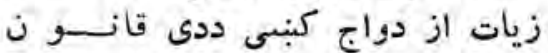

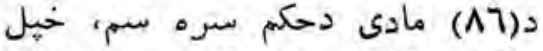

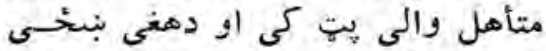

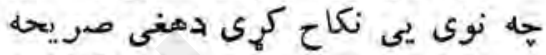

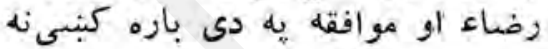

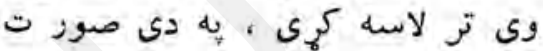

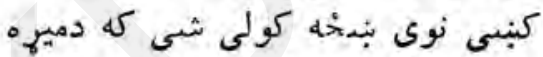

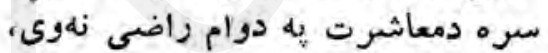

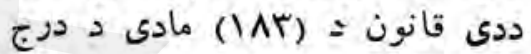

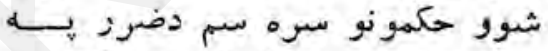

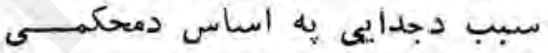

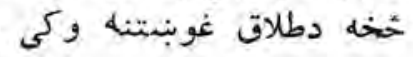
اووم مبحث - دازدواج آثار

$$
\begin{aligned}
& \text { لمهى فرعه - عمومى حكمونه } \\
& \text { o } 0 \text { - } 9 \text {. }
\end{aligned}
$$

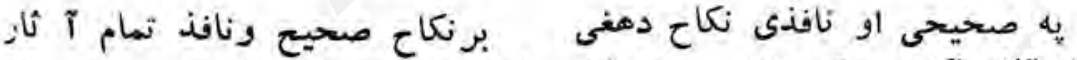

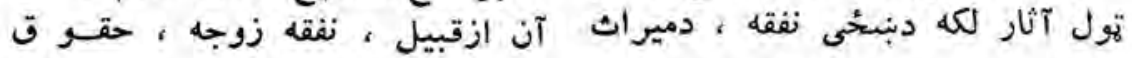

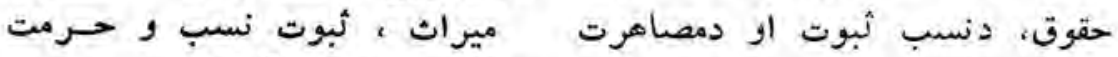

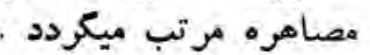
ماده

در مورد لزوم كل مهر ، خلوت

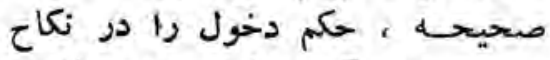

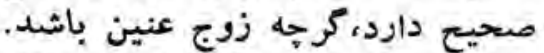

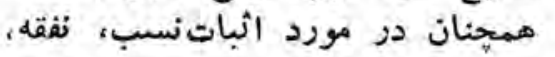

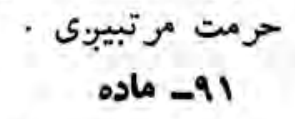$$
\text { دتول مهر دلزوم يه ماده باره كنبهى }
$$

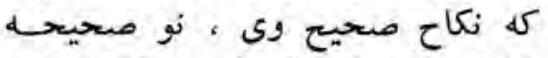

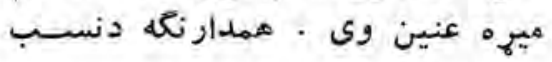

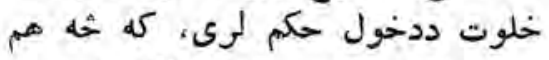




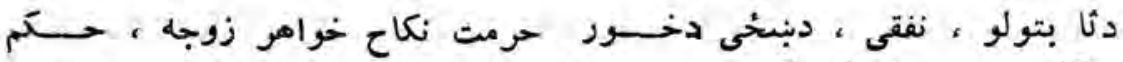

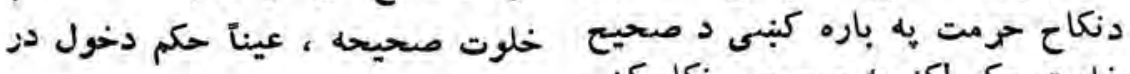

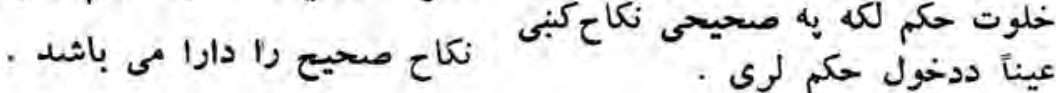
- Ar os

$$
\text { or }
$$

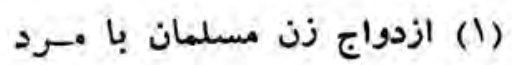

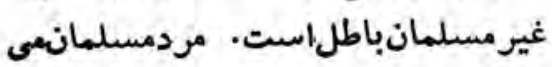

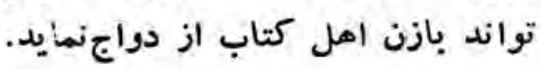
ولماب ازدواج زن اهل كتاب توسط ولى كتابى وى بحضور دو نفرشاهد اهل كتاب صورت كرفته مي وتواند. در موارد مندرج اين ماده اولاد تابع

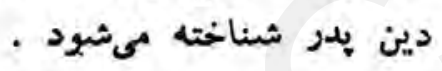

$$
\text { - }
$$

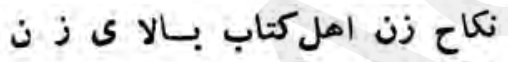
مسلمان وعكس آن جواز دارد .

$$
\text { - } 98 \text { ماده }
$$

هركاه در نكاح غير صحيح بين

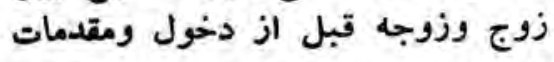

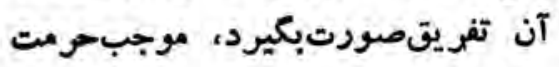

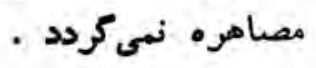

$$
\text { - } 90 \text { مادم }
$$

ميع يك از آنار از دواج صحيع برازدواج باطل كرجه دخول در آن صورت كرفته باشد، مرتب نهيكردو.
دان (1)

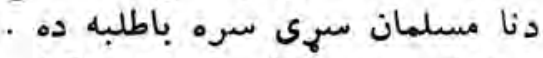

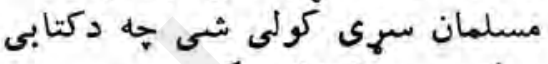

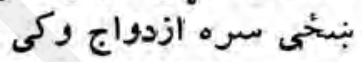

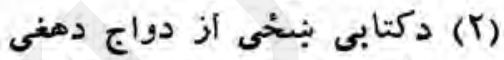

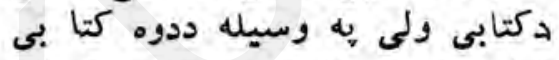

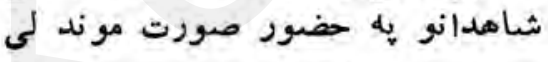

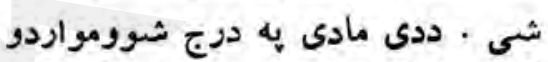

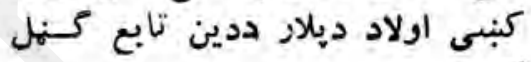

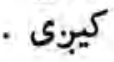

$$
\text { rar }
$$

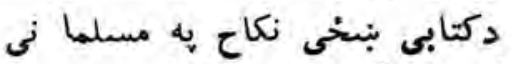

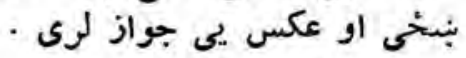

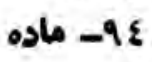

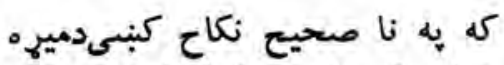

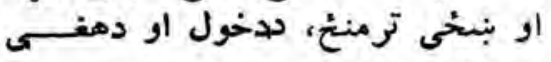
دمقدمو ترمخه جدايى صورتومومئ، دموني، دمصاهرت دحرمت موجبنه كرخى.

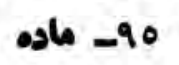

يه باطل از دواج كه خها مبدهول يه كنبسى صورت موندلى

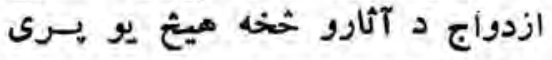
نه مرتبين 


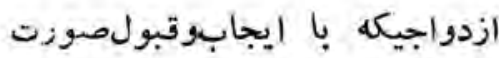

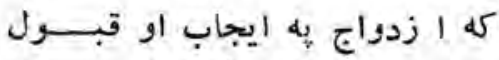

كرفته وبعضى شرايط آن تكميــــل

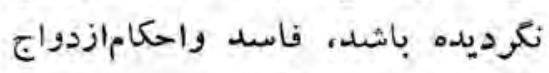

$$
\begin{aligned}
& \text { برآنمرتب نمى كردد . نمدهد } \\
& \text { - ar ar }
\end{aligned}
$$

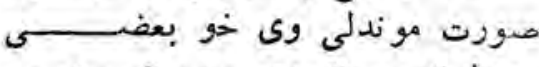

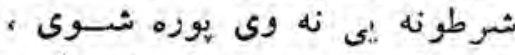

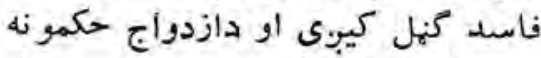

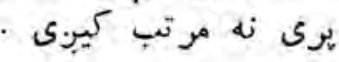

$$
\text { ماده }
$$

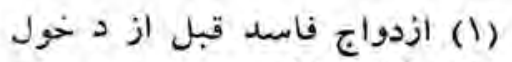

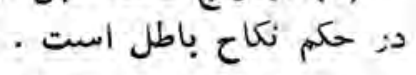

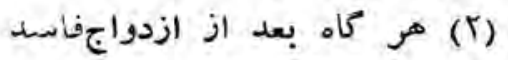

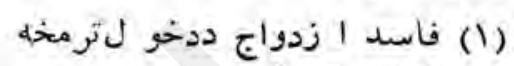

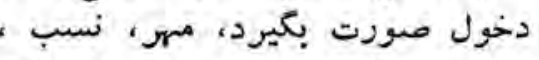

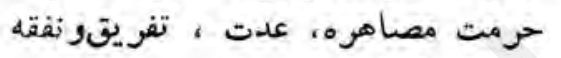

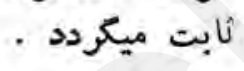

$$
\begin{aligned}
& \text { فرع دوم - مهر } \\
& \text { - } 11 \text { - ماده }
\end{aligned}
$$

كل همر باوطى، خلوت صحيحهيا

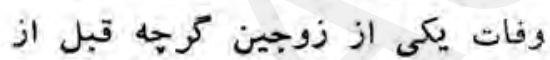

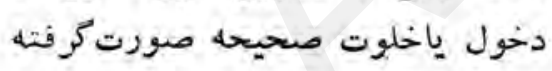

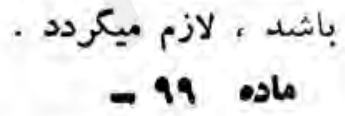

زوجهمستحق مهر مسمى مئياشد.

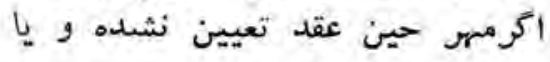

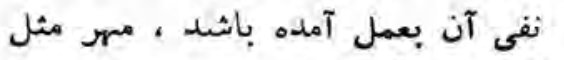

$$
\text { لازم مق كرد آل }
$$

(r)

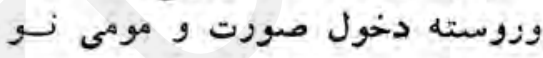

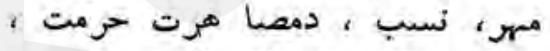

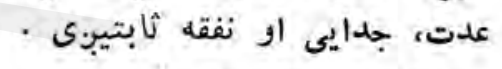

$$
\text { دوهمه فرعه - مهر }
$$

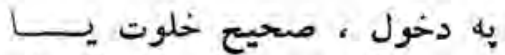

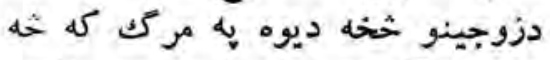

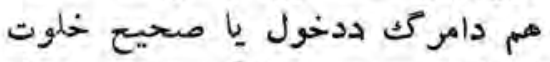

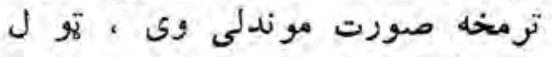

$$
\text { • مهر لازميبين }
$$$$
99 \text { 9 ماده }
$$

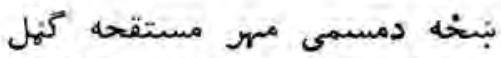

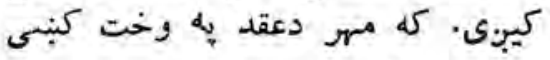

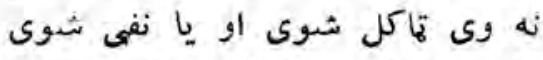

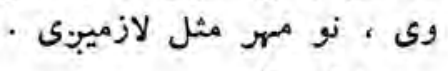

$$
\text { -1.. }
$$

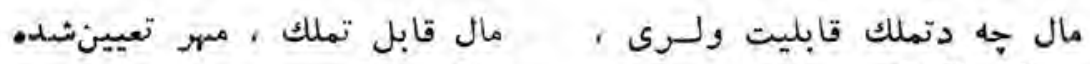

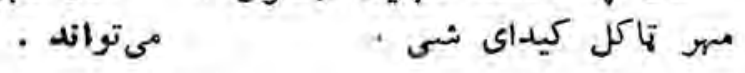




$$
\text { ماده }
$$

(1)

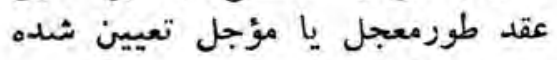

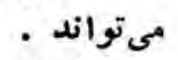

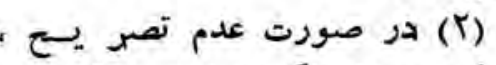

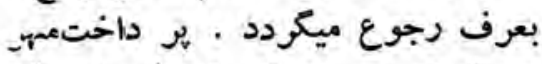

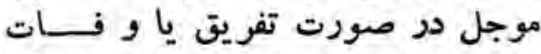

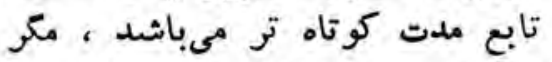

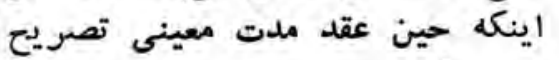
شده باشد ماده عند

$$
\text { ماده }
$$

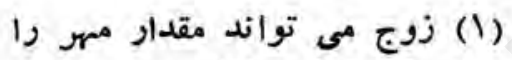
بعد از عقد تزئيد نمايد تواند مقدار

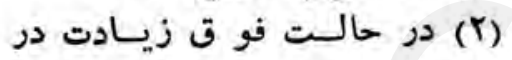

مهر تابع شرايط ذيل است :

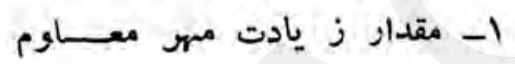

ז- زوجه ياولى او اين ز يادترا

$$
\text { قبول نمايد زوات }
$$

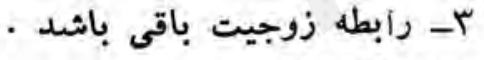

$$
\text { - ماده }
$$

(1) زوجه بالغه كه سن ازدواج

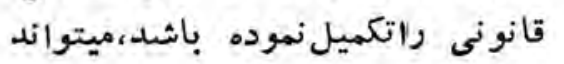
درحالت صحت ورضاى خود مهرى

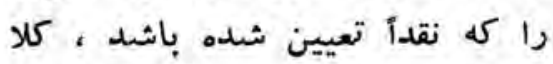

وياقسماً از ذهه زوج ساقط نهايد.

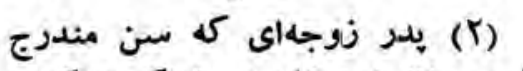

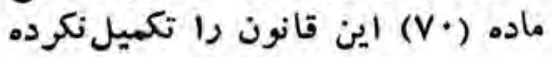

\section{$00-1 \cdot 1$}

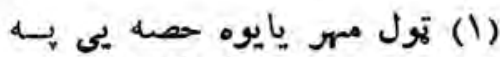

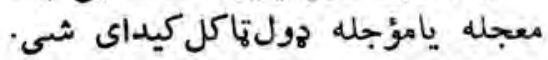

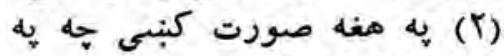

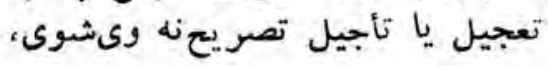

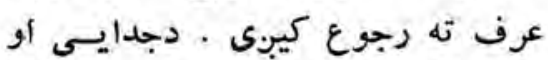

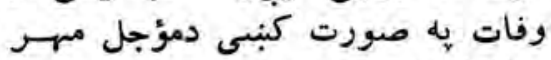

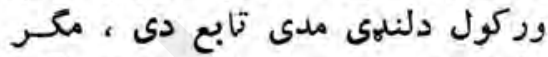

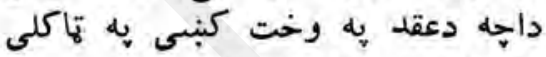

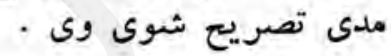

$$
\text { r }
$$

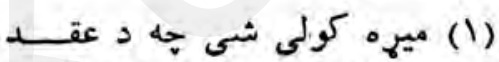
خخه وروسته دمهي الندازهزياته

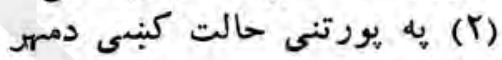

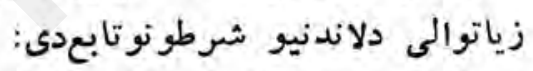

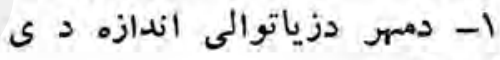
مeلومه وى

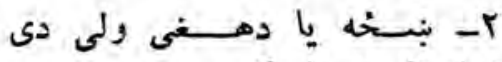
دا زياتوالى قبول كئ

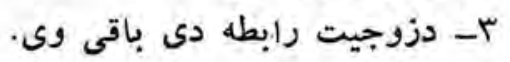

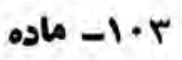

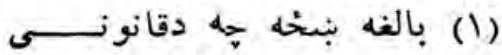

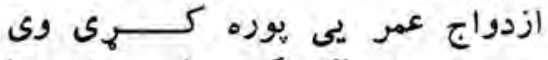

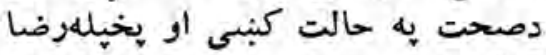

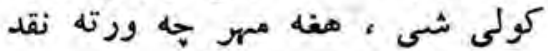

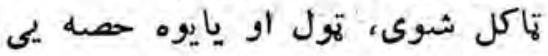

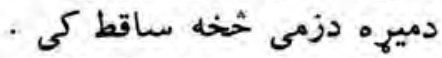

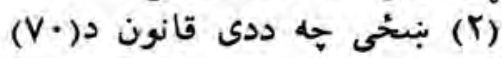
مادى درج شوى عمر ني نه نه ودى بون بوره 
باشد + بهيت صورت نميتواند مهررا

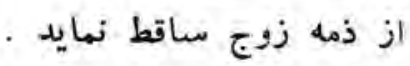

\section{ماده}

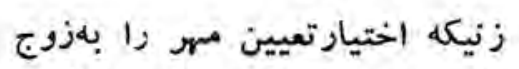
تفويض نهوده و مهر اوتسميهن نشيده

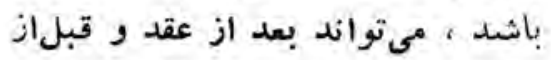

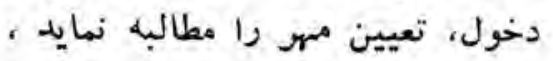
زوج مكلف است مهر اورا معين كند.

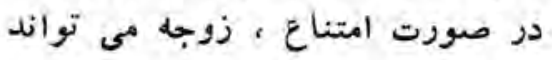
تعيين مهر مثلرا از محكمهباصلاحيت

$$
\begin{aligned}
& \text { مطالبه بدازد مهردئ } \\
& \text { ماده } 1.0
\end{aligned}
$$

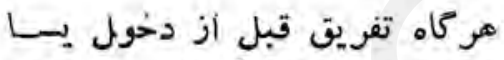

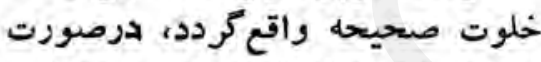
تسميه، زوجه نصفمهري مستمىودرغير آن نصف مسهر مثل زو را مستحهـ

$$
\text { مى شود . ماده } 1.7
$$

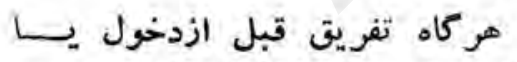

خلوت صحيحه ازطرف زئ زوجهاهورت أدون كيرد، مهر وى كاهلا ساقط ميكردد.

$$
\text { - I.V مادم }
$$

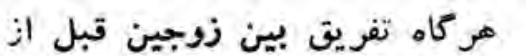
دخول يا خلوت صحيحه واتع كردد ودئ

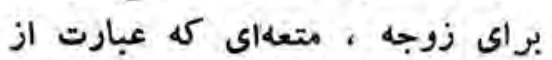

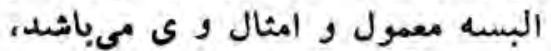

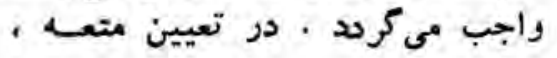

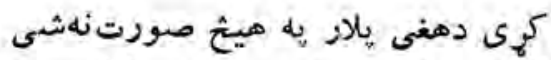

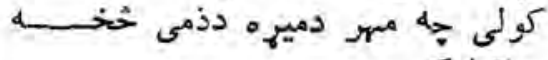
ماقط كولى

$$
\text { (1) - } 1 \text { - }
$$

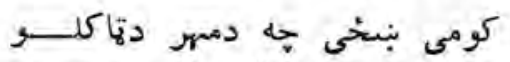

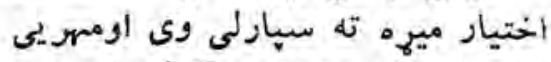

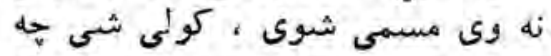

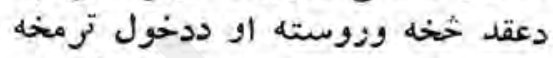

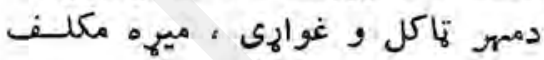

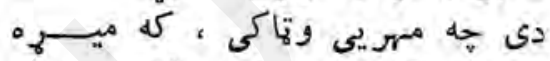

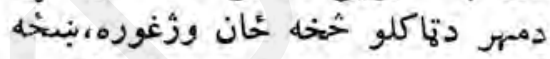

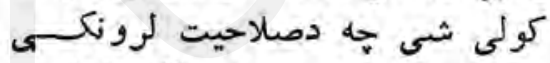

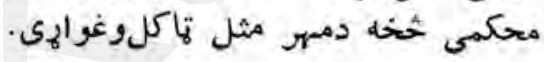

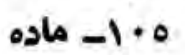

كه جدايى ددخول يا صحيع ماده

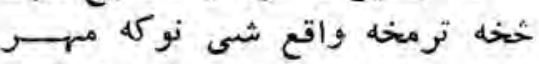

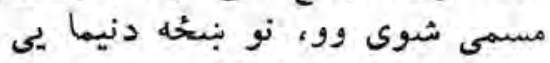

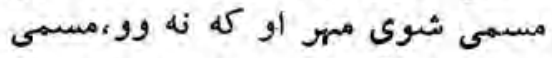

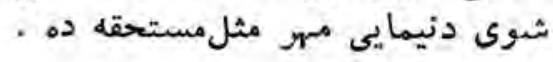

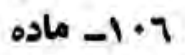

كه جدايى دصحيح خلوت يادخول

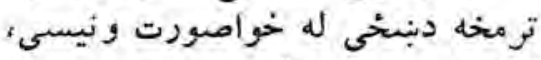

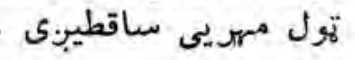
- I.V

كه دزوجينو ترمنيخ جداييددخول

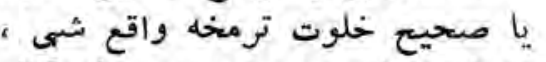

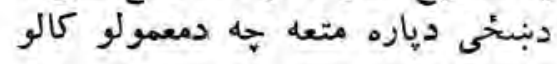

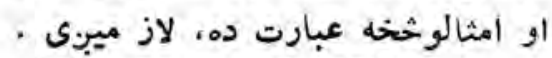

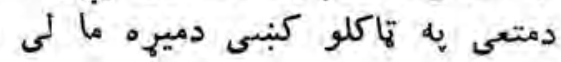
(5.) 


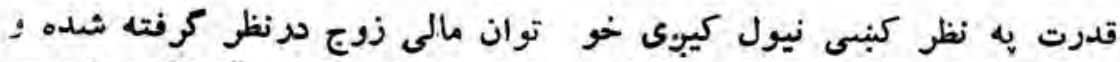

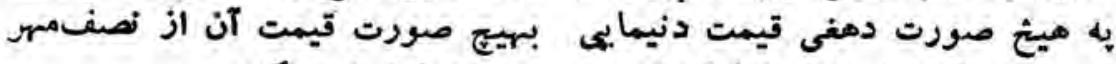

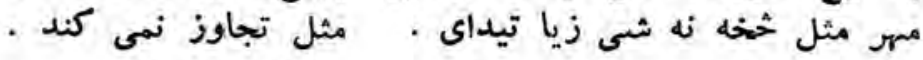

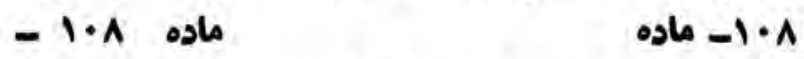

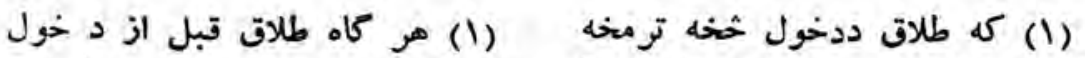

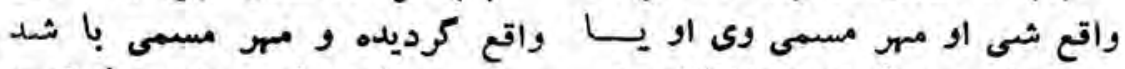

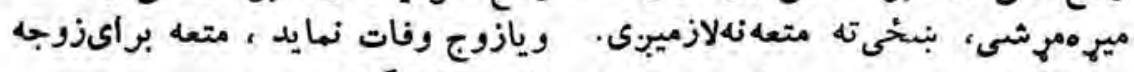

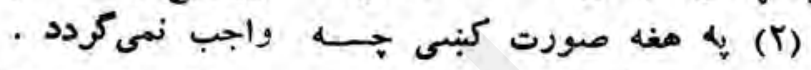

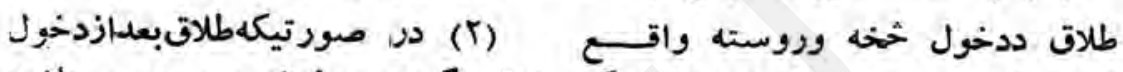

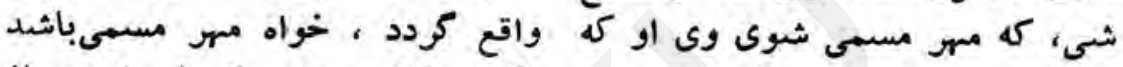

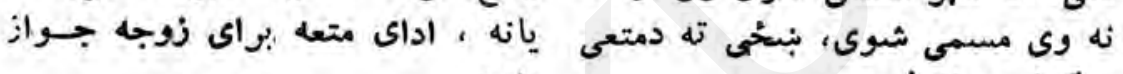

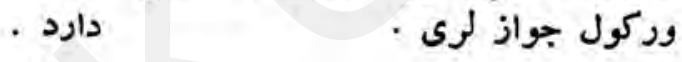

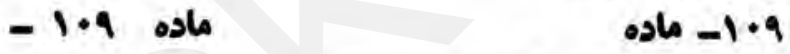

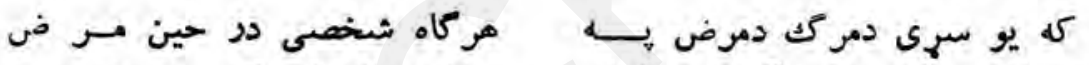

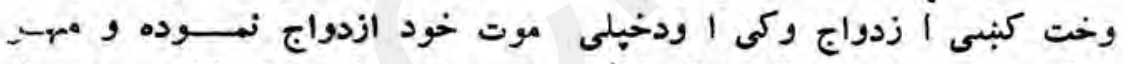

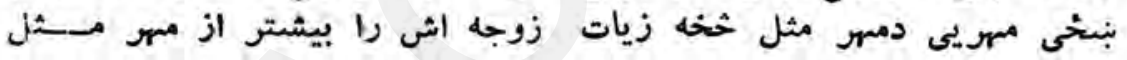

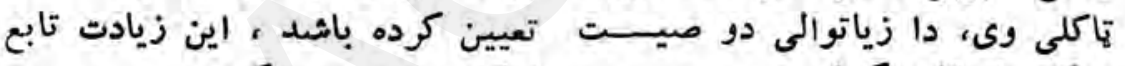

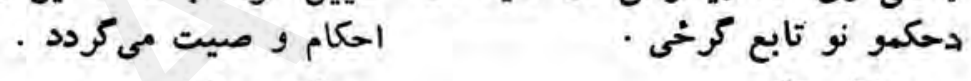$$
\text { - 11. ماده - 11. }
$$

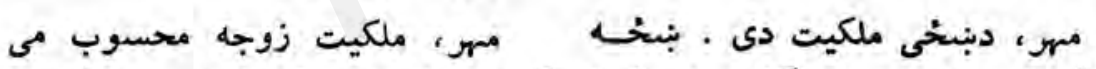

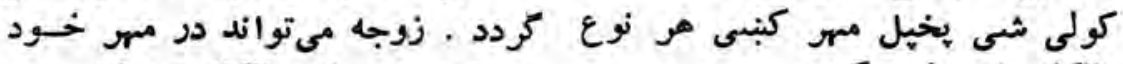

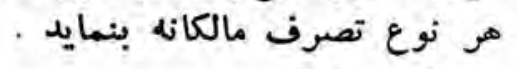

$$
\text { ماده }
$$$$
\text { مالكانه تصرف وكى وكى }
$$$$
\text { (111 }
$$

هر كاه زوجه كل مهره يا له قسمتى

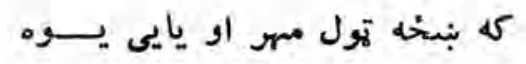

حصه دقبض خخخه ترمخه ياوروسته خبل ميره ته هبه كمى او ددخول

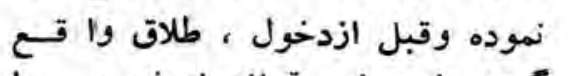

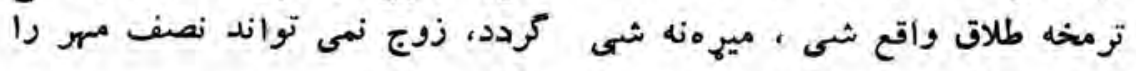

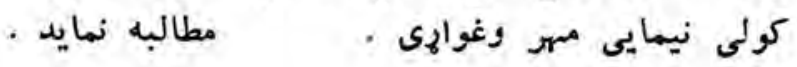




\section{ماده}

هر كاه مهر يول نقده ياشهى مثلى

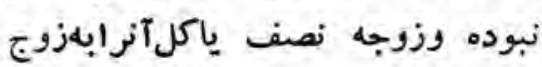
هبه نمايد ، در صورت و قوع طلاق

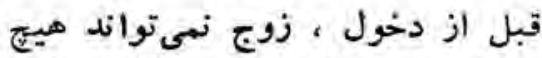
جيزى را به عنوان ههر مطالبه نمايد.

$$
\text { - lir }
$$

يدر نميتواند مهر دختر خـودرا

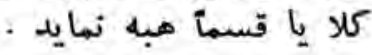

$$
\text { ماده }
$$

زوجه هجبور كردانيده نمى شود،

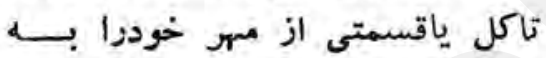
زوج ياشخص ديكرى واكذار شود. درصورتيكه زوجه قبل از قبض كل مهر وفات نمايد ، ورثله وى مى تواند از زوج ودر صورت وفاتزوجازوزئه

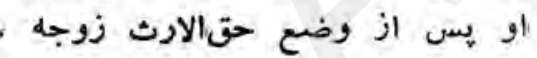
مهر بأقيمانده را مطالبه نمايند . مالان

$$
\begin{aligned}
& \text { فرع سوم - مسكن } \\
& \text { - } 110 \text { o }
\end{aligned}
$$

زوج مطابق به توان مالى خــــــ

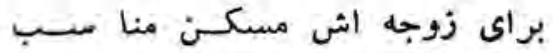

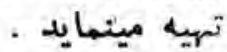$$
\text { ماده }
$$

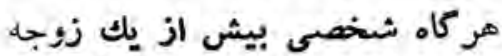

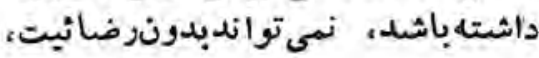

$$
\text { r }
$$

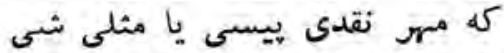

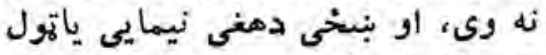

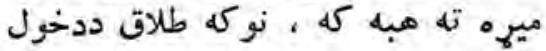

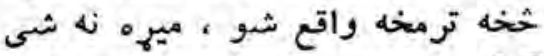

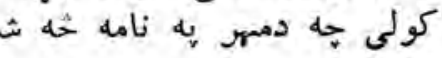
. وغوارى

$$
\text { rاري }
$$

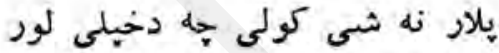

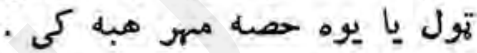

$$
\text { أو }
$$

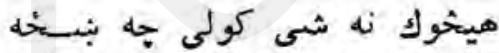

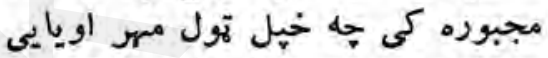

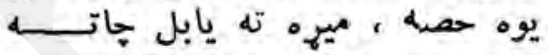

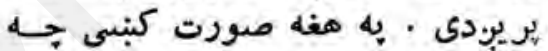

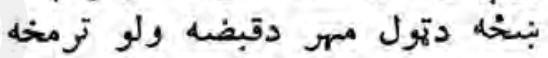

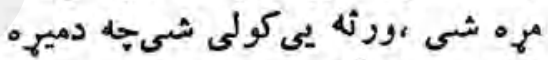

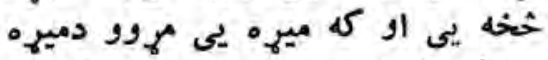

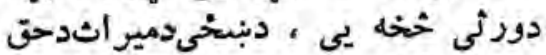

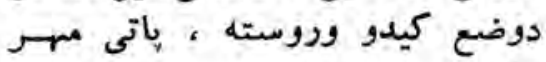

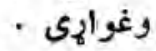

$$
\begin{aligned}
& \text { دريمه فرعه - داوسيدلو خائ } \\
& \text { 110 }
\end{aligned}
$$

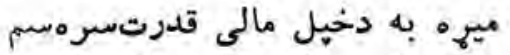

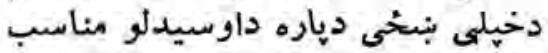

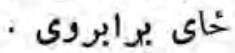
711

كه يو سهى ديوى خخه زيا تهى ماده

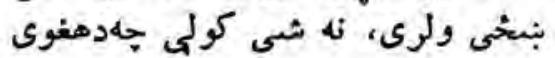




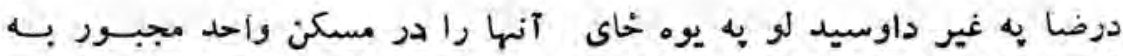

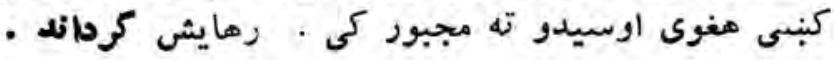

$$
\begin{aligned}
& \text { فرع حارم - نفقه } \\
& \text { خلورمه فرعه - نفقه } \\
& \text { - IIr مادم } \\
& \text { V V III }
\end{aligned}
$$

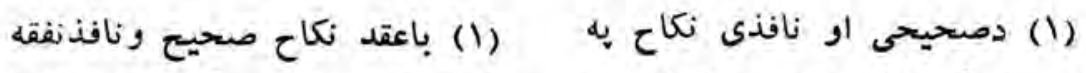

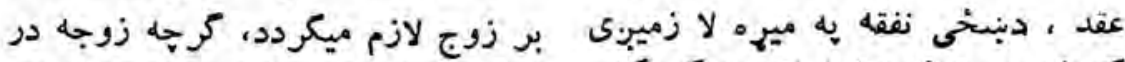

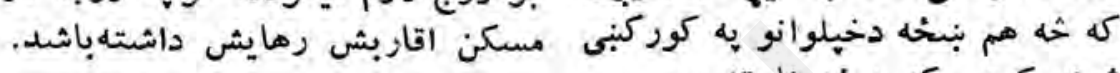

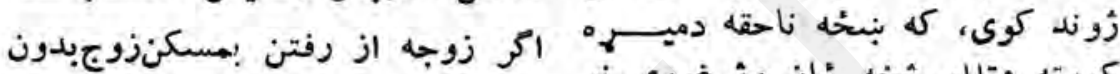

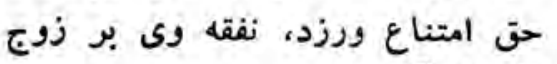

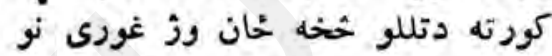
لازم نميكردد .

(r) زوجه وقتى حتى داردازرفتن

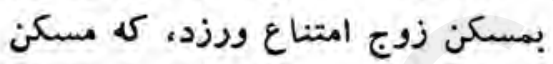
مناسب مطابق به ماده (11) اين قانون از طرف زوج تهيه نشاسي ماده

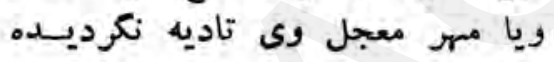

$$
\text { - I11 ماده }
$$

نفقه زوجه مشتمل است برطعام، لباس ، مسكن وتداوى متناسب به - توان مالى زوب ماده - 119 ماده هركاه زوج از اداى نفقه ا متناع ورزد ياتقصير وى در آن ثابت كردد، محكمه باصلاحيت زوج را با دا ى نفقه مكلف ميكرداند .

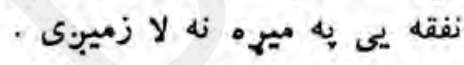

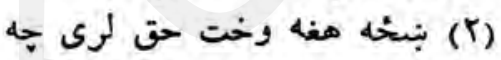

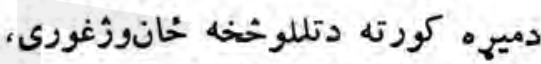

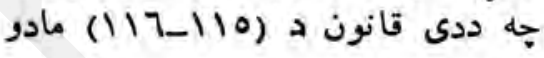

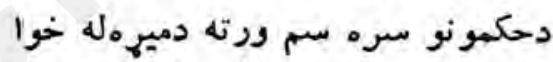

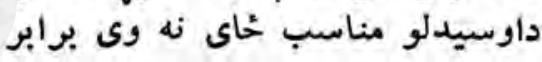

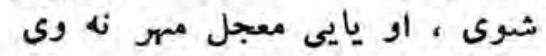

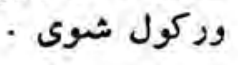
111

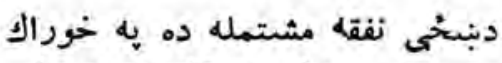

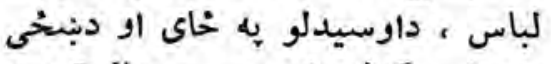

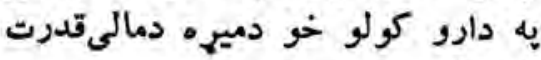

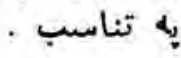
كه

كه ميهه دنفقى دور كولو خخخهـــ ماده

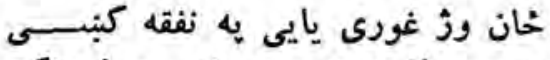

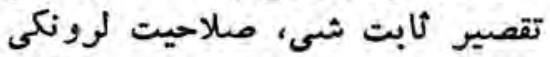
محكمه به ميره دنفقى يه به ور كولـو مكلفه وى محكن 


$$
\text { كاد - (1T) }
$$

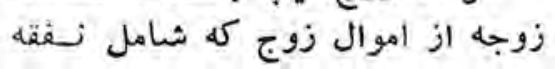
شده بتواند وبدسترس وى أند قـراز

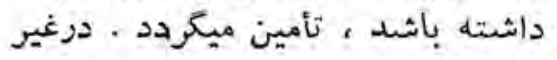

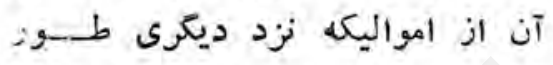
وديعت يادين دارد، نفقه زوجهاتعيين

$$
\text { ميكردد . }
$$

\section{-}

درحالات ذيل زوجه مستحق نهته

$$
\text { نهى : نود : }
$$

ا- زوجه بردون بدون اجازه زوجيابعير

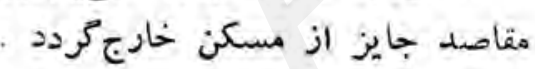

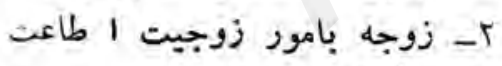

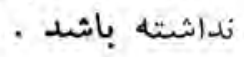

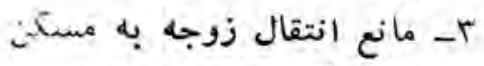

$$
\text { زوج موجود باشد ماند التقال }
$$

\section{ماده}

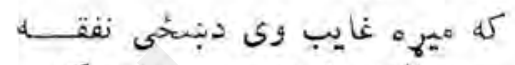

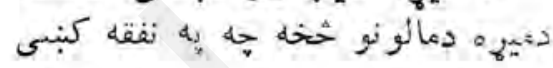

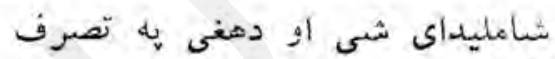

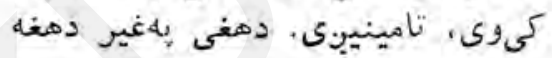

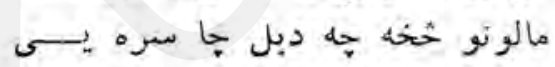

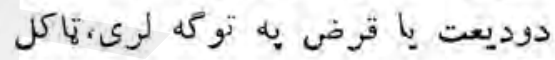
كيبزى

$$
\text { r }
$$

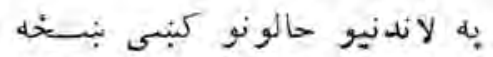

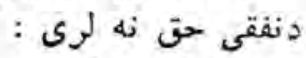

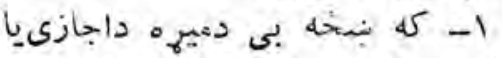

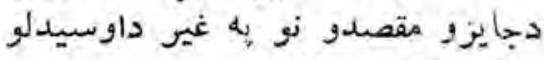

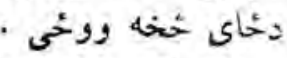

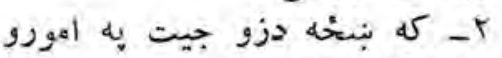

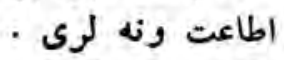

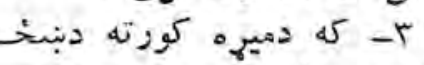

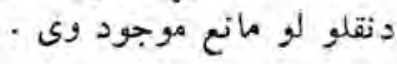

$$
\text { rir }
$$

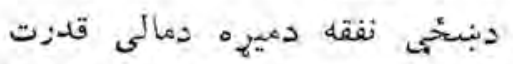

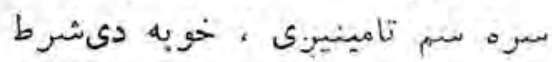

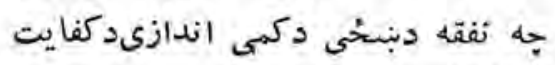

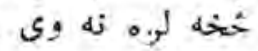




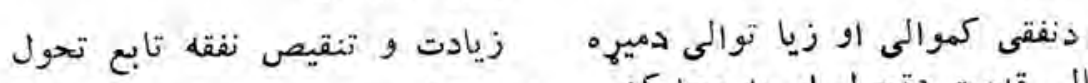

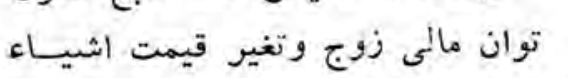

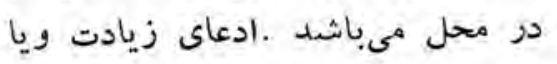

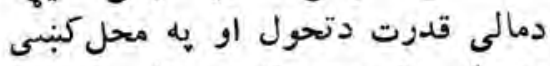

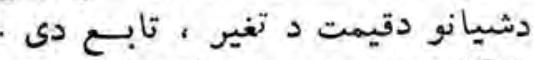

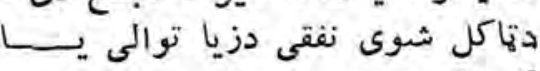

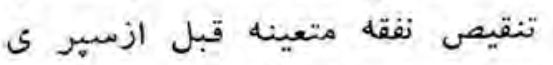

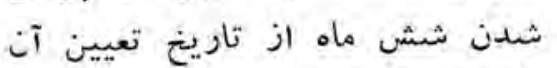

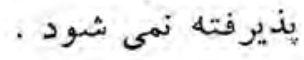

$$
\begin{aligned}
& \text { ماده }
\end{aligned}
$$

هركاه زوج از اداى نفقه واجبه

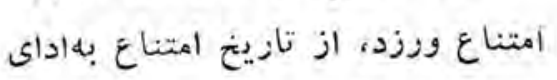

$$
\begin{aligned}
& \text { نققه زوجه مكلف ميكردد . } \\
& \text { ماده רז زوج4 }
\end{aligned}
$$

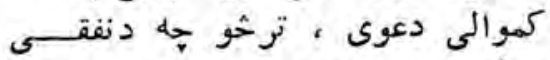

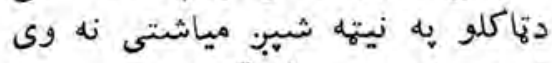
تيرى، نه او ريدله كيبو نهيه

$$
\text { مrا- ماده اون }
$$

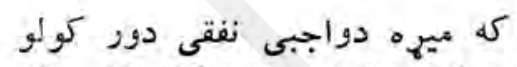

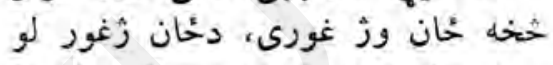

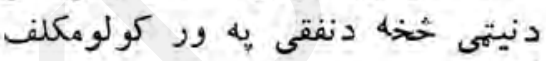

مطلقه از ثاريخ طلاق تاختم عدت

$$
\begin{aligned}
& \text { مستحق نفقه ميكردد . } \\
& \text { - IrV }
\end{aligned}
$$

ادعاى مطلقه دز مورد نققه ايـأم عدت اكر بيشتر از يكسال از ناريت

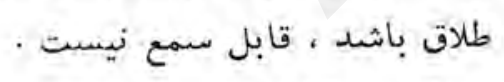

$$
\text { - Ira os }
$$

نفقه واجبه جز به اداء يـابرهاء

$$
\text { ازآن ساقط نمى كردد . }
$$

$$
\text { דri }
$$

طلاقه شبوى دطلاق دنيتى خخده

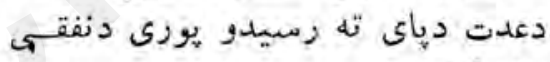

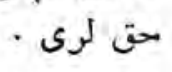

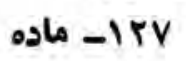

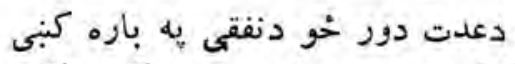
دطلاقى شوى بنبخى دعوى كه دطاق دور ديلاق

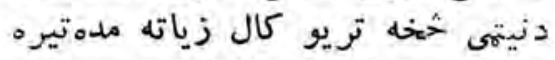
شوى وى، نه اوريدل

$$
\text { 1 1 ا- ماده }
$$

واجبه شوى نفقه بى لله اداءكولو ماده

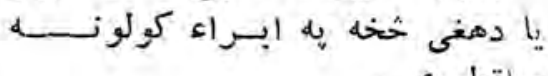

$$
\begin{aligned}
& \text { ساقطيب.ى } \\
& \text { 9 }
\end{aligned}
$$

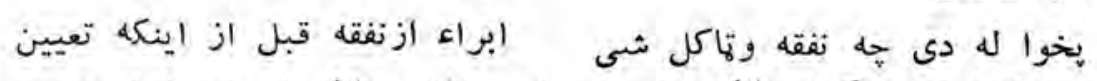

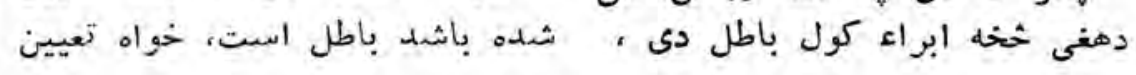


عام له دى جه دنفقى تعيين رضايىوى نفقه رضائى باشد يا قضانئ.اماابراء

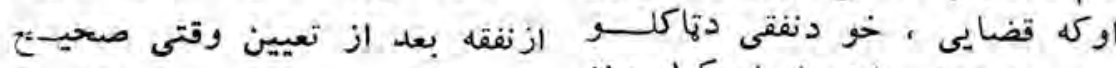

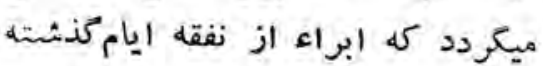

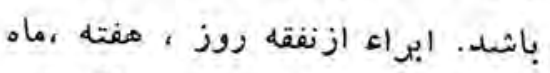

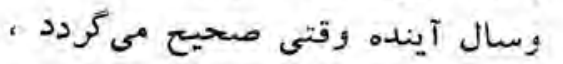

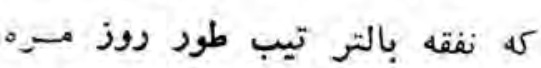

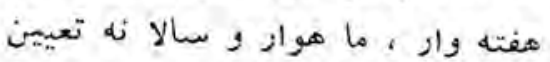

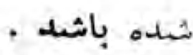
ماده

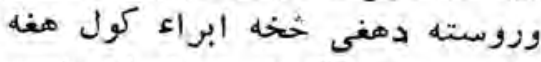

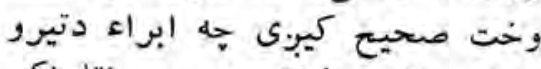

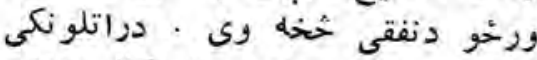

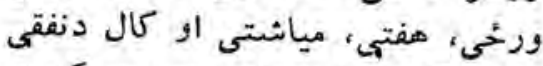
ابراء كول هغنه وخت صحيت كيبيني

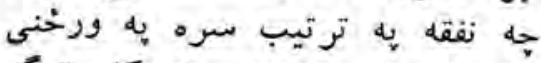

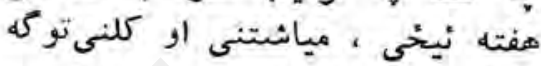

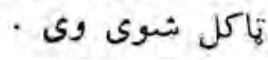

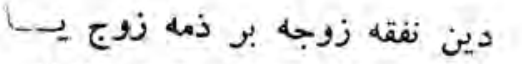

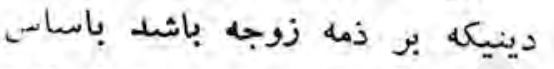

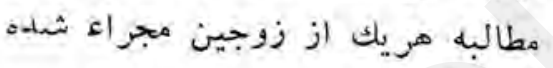
مى متواند

مبحث هشتمر - انحلال ازدواج

$$
\text { ماده فرع اول - احكام عمومى }
$$

عقد ازدواج بافسنغ ، طلاق، خأع

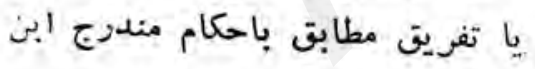

$$
\begin{aligned}
& \text { قانون منحل ميكرد د. } \\
& \text { فرع دوم - فسنخ } \\
& \text { - Irr }
\end{aligned}
$$

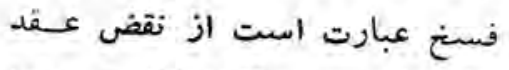

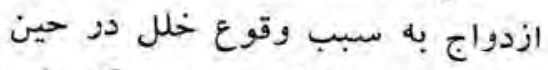
عقد و يابعد از آن، به نحويكه مانع

$$
\text { دوام ازدواج كردد . }
$$

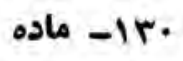

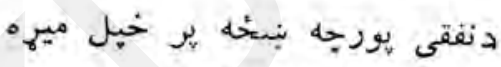

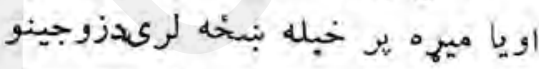

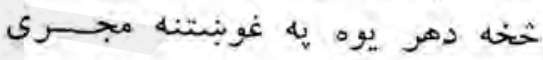

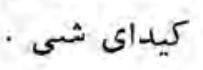

اتممبحث- دازدواج منحل كيدل لمهى فرعه - عمومى حكمونه

$$
\text { | ابا- ماده }
$$

ددى قائون ددزج شورو ماده حمو لو

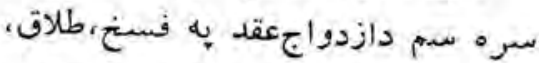

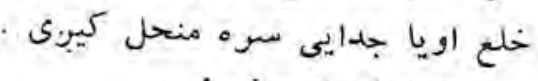

$$
\text { دوهمه فوعه - فسنخ إدي ماده }
$$

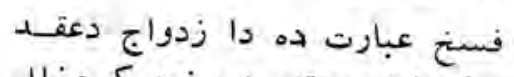

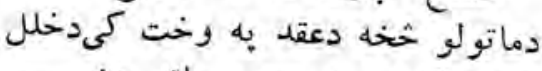

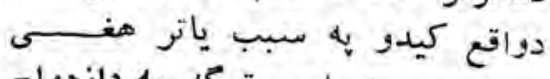

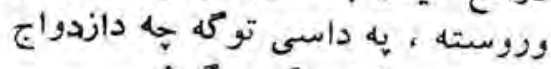

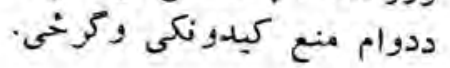




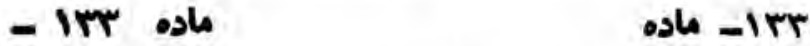

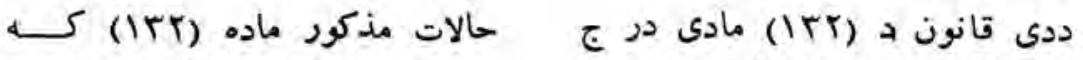

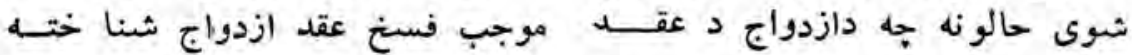

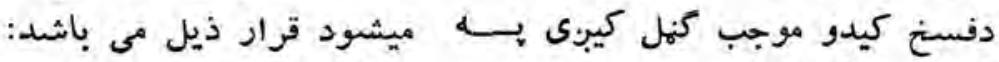

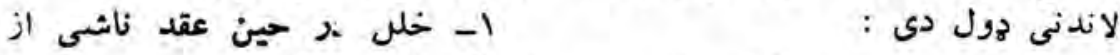

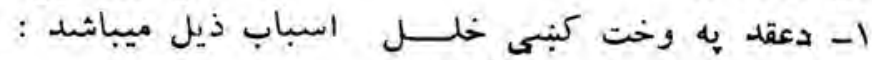

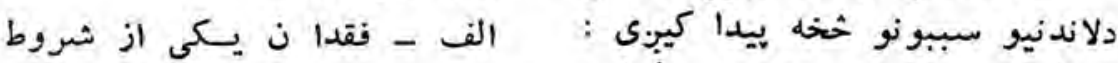

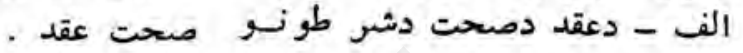

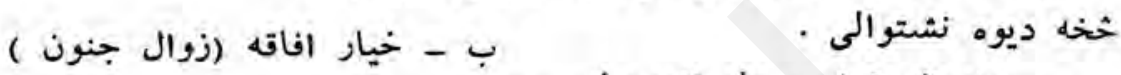

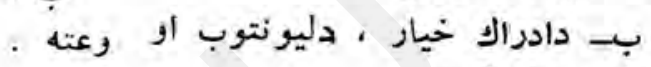

ج- نقصان مهر از اندازه مهر

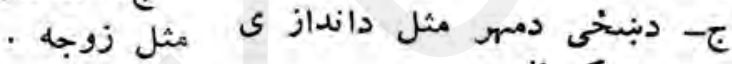

r- خلل بعد از عقد كه مانعدوام مانم ازدواج ميكرند، ناثيى از اسبابذيل ميباثد الندواج مي

الف - حرمت مصاهره . - ماند خخه دمهر كموالى

r- دعقد خخه وروسته كو مخله

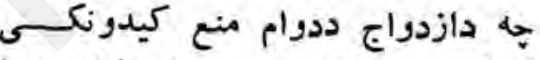
كرخى ، دلاندنيو سببو نو خخه بيدا دوريد ب- لعان

ج- امتناع زوجه غير كتابسى از مسلمان شدن در صورتيكه زوج او

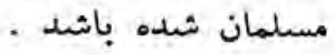
- Ire ج- دغير كتابى بنسخى دمسلمانى

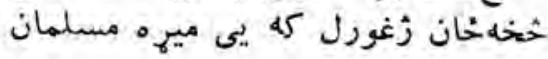
كيبِى : كرحى : الف - دمصا هرت حرمت

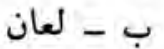

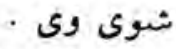

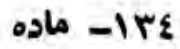
(1) فسنخ عقد ازدواج در هردو

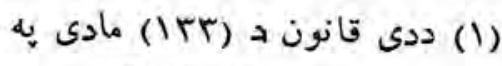
حالت مندرج ماده (rrآ) اينقانون بحكم قطعى محكمهباصلاحيت صورت

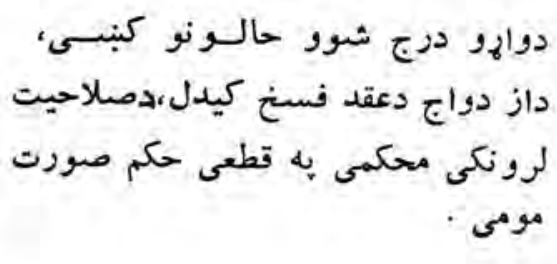




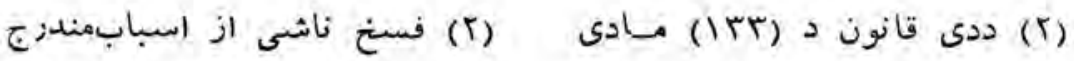

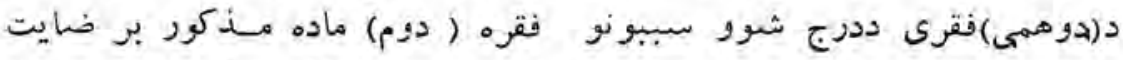

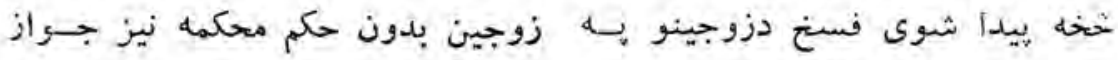

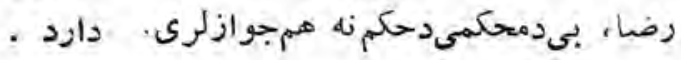

$$
\begin{aligned}
& \text { فرع سوم - طـلاق } \\
& \text { - } 1 \text { 1ro }
\end{aligned}
$$

(1) طلاق عبارت از انحلال زابطه (1)

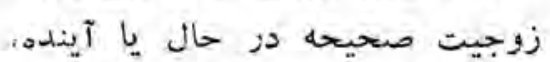

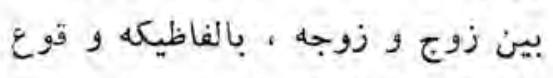

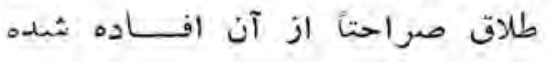

$$
\text { بتواند بلد }
$$

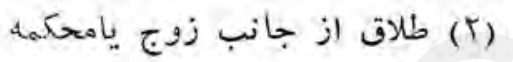

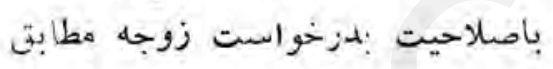

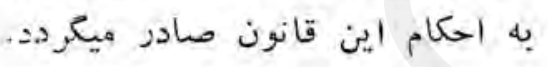

$$
\text { ماده }
$$

طلاق ننها بالاى زوجه ايكه 2.

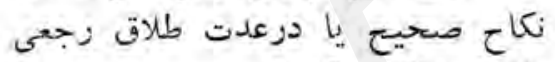

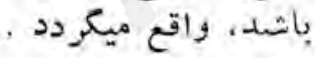

$$
\begin{aligned}
& \text { - IrV }
\end{aligned}
$$

طلاق هر زوج عاقل و بالغ واقع ماده

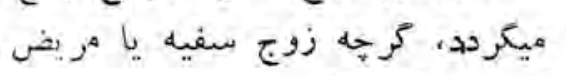

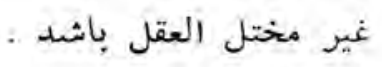

$$
\text { - ماده }
$$

$$
\begin{aligned}
& \text { دريمه فوعه - طلاق } \\
& \text { مrا- ماده }
\end{aligned}
$$

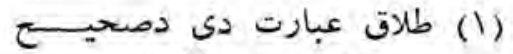

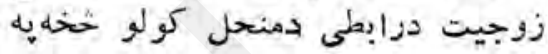

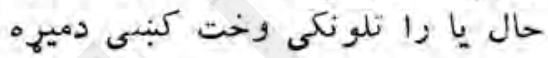

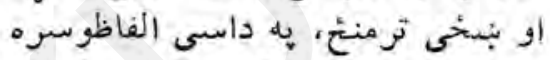

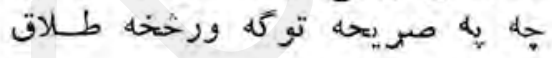

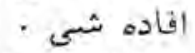
طاق (ז) ددىقانون دحكمو نو سرهمب،

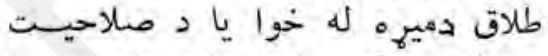

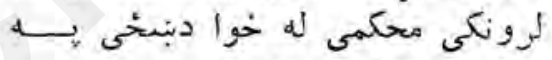

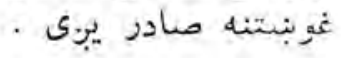

$$
\text { 7 }
$$

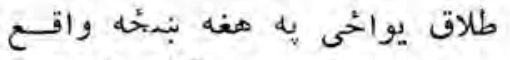

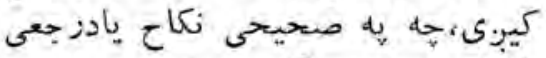

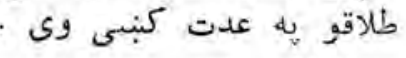

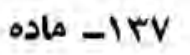

دمر عاقل بالغ ميهـ طلاق واقهـ

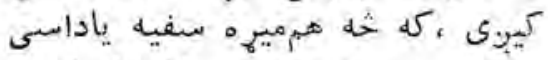

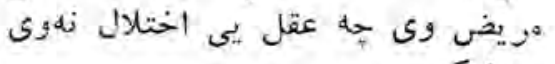

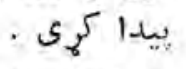

$$
\text { אזו- ماده }
$$

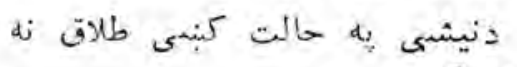

$$
\text { واقع كيبنى }
$$




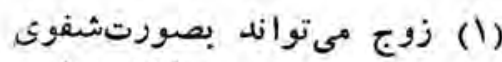

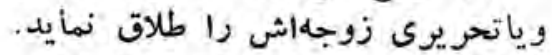

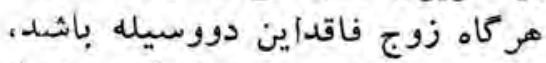

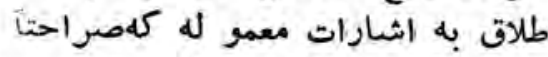
طلاق را افاده نمايد ، صور ت لهورات

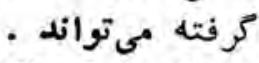

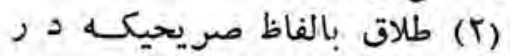

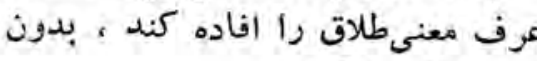

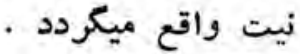

$$
\begin{aligned}
& \text { ماده • 1E }
\end{aligned}
$$

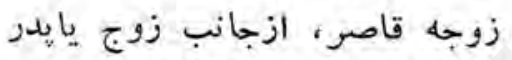

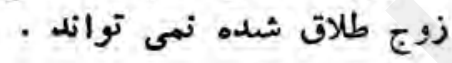

$$
\text { - |El }
$$

طلاق اشخاص ذيل اعتبارندازد: 1- مجنون ، مكر در صو صو زتيكه

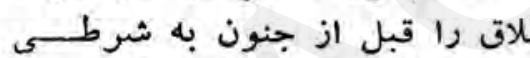

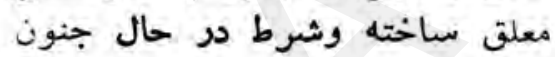

$$
\begin{aligned}
& \text { موجود شود . ماخته } \\
& \text {. } \\
& \text { - r } \\
& \text { - ع - نايم }
\end{aligned}
$$

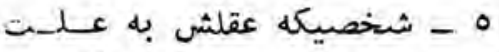
زيادت سن و يا مرض مختل كرديده

$$
\text { باثد }
$$

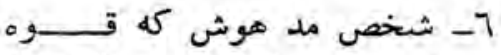

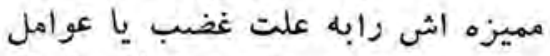

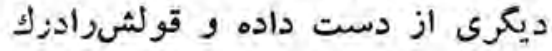

(1)

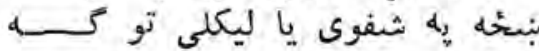

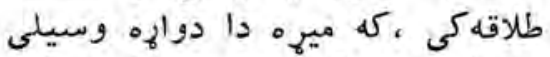

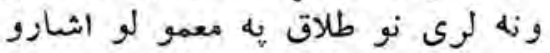

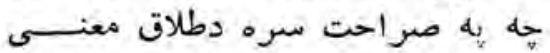

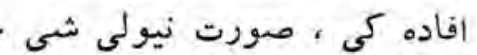

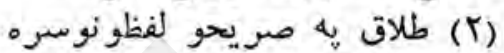

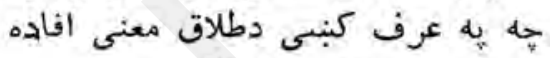

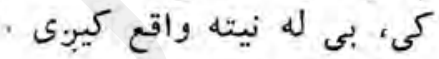

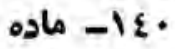

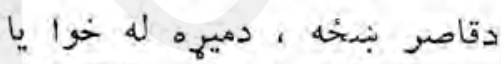

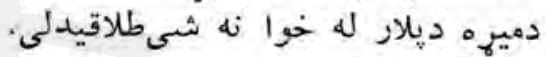

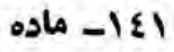

دلاندنيو اشخا صو طـلاق اعتبار

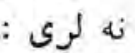

1- دليونى، مكر به به هغه صورت

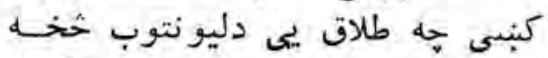

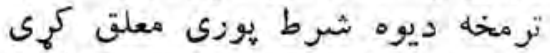

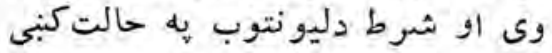

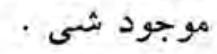
r

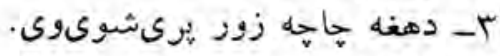

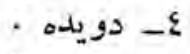

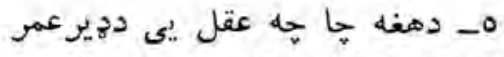

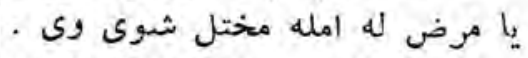

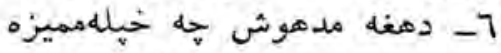

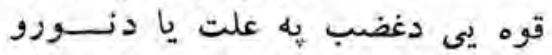

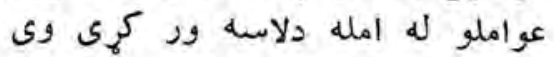

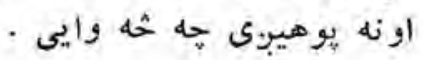




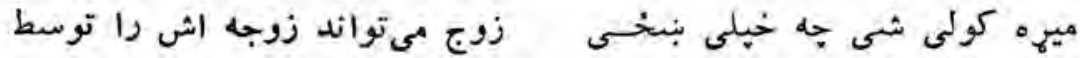

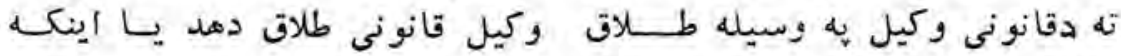

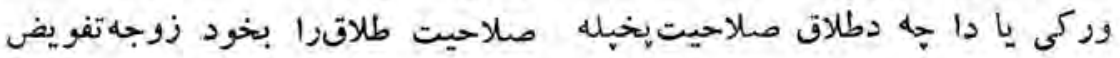

\section{- ler}

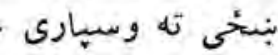

$$
\begin{aligned}
& \text { r }
\end{aligned}
$$

زوج بعد از تفويض صلاحهيت طلاق أناق

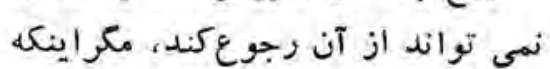

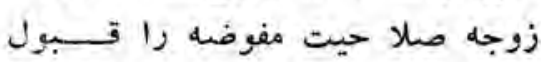

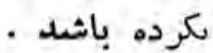

\section{- ler}

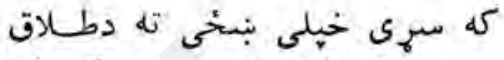

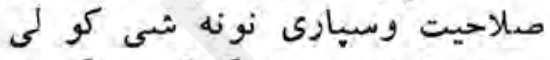

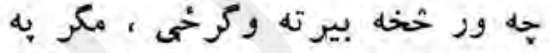

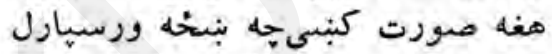
شوى صلاحيت قبول نه كنى \& E

زوج در برابر زوجه صلاحيتسه

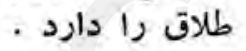

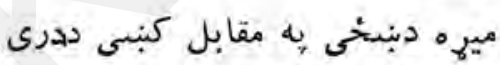
ماده طلاقو صلاحيت لرى دوني له 0 إ- ماده

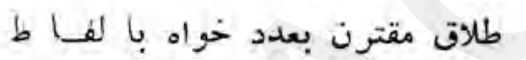
طلاق دعدد سره يو خاى عامله دى ماده

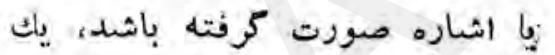

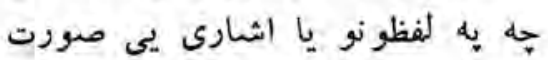
طلاق شناخته ميشود . ماده موندلى وى ، يوطلاق كنه كيل كيبوى . - IET 7ع ا- ماده

ظلاق بطور عموم زجعىودزموارد طلاق به عمومى صوزت رجعىوى، ذيل باين مىباشد : بطور

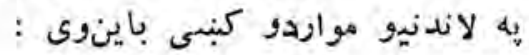

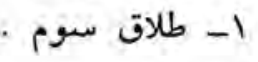
1- دريم طلاق . ندئ. r- طلاق قبل از دخول . r- ددخول خخه ترمخه طلاق .

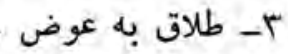

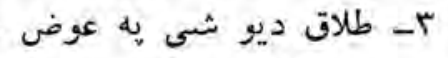

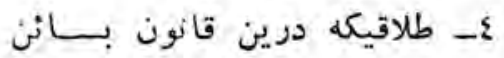

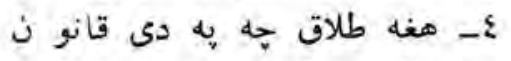
خوانده شده :

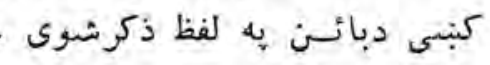




$$
\text { - IEV os }
$$

زوج نهىتواند با مطلقه ثـلا أه

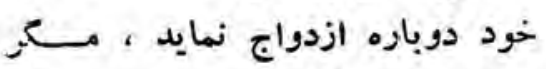

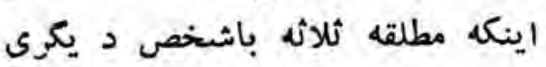
ازدواج نموده وبعد از دخولازدواج دومى طلاق كرديده وعدت را تكهيل كرده باشد طاش كردم

$$
\text { - IEA مادم }
$$

هرنوع طلاق زوجه قبل ازدخول

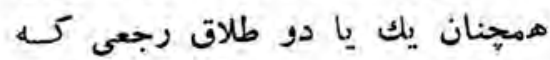

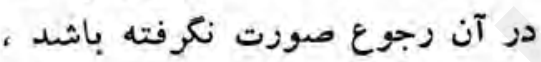

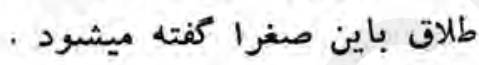

$$
\text { - } 189 \text { ماده }
$$

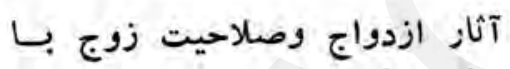

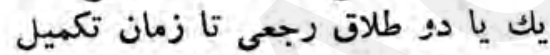

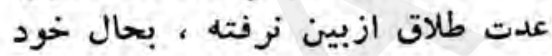

$$
\text { ماقى مى ماند ماند إنين }
$$

تعليق رجوع بزمان آيندهيابكدام شرط جواز ندازد . در صحت رجوع برمان

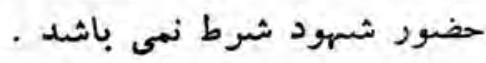

$$
\text { ماده }
$$

رابطه زوجيت در طلاق رجعى با ياك شدن از حيض سوم قطع وحق رجق رجوع زوج ساقط ميكردد ل

$$
\text { - إد }
$$

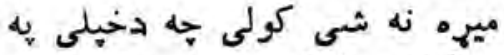

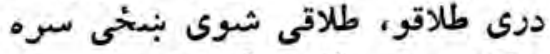

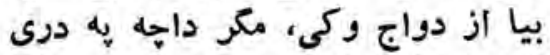

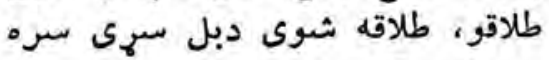

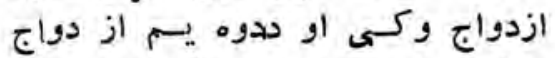

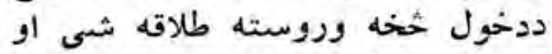
عدات هورج

$$
\text { 1 ا- ماده }
$$

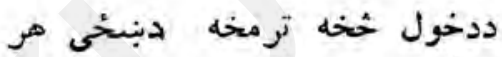

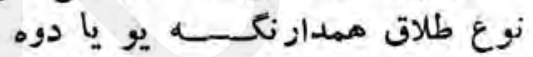

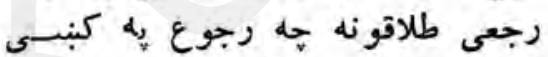

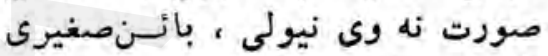

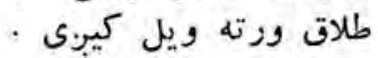

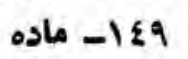

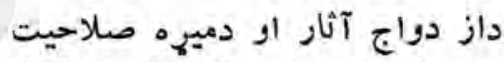

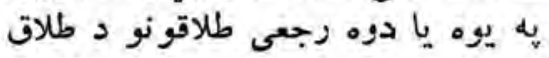

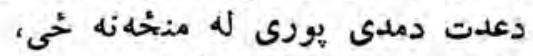

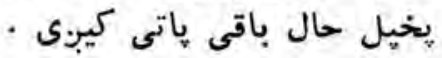

$$
\text { 10. }
$$

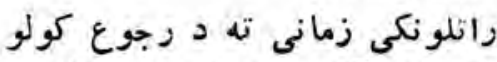

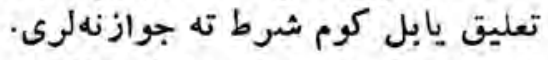

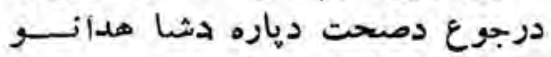

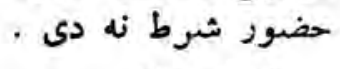
os - 101

يه رجعى طلاقو كنبى دزو جيـت

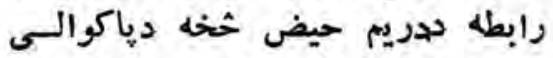

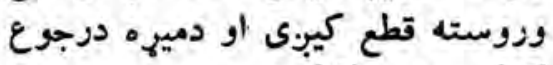

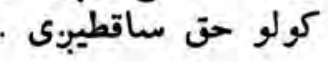


طلاق باين صغرا عقد ازدواج راه

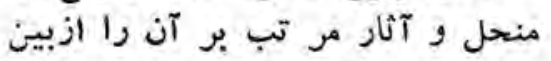

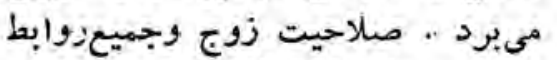

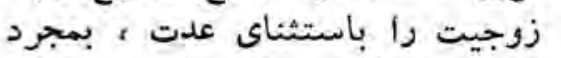

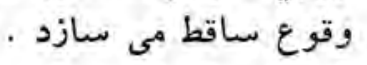$$
\text { - lor }
$$

(1) طلاق :ائن صغراموجب أبرمت

ازدواج مطلقه به زوج نمى كردد .

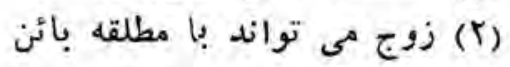
صغرا در حين عدت و يابعد از آن مجدداً أزدواج نمايد، مشروط بر اينهد اين ازدواج برضاى زن و به عقد و

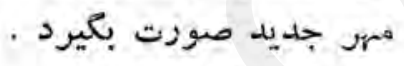

$$
\text { مأده }
$$

هر كاه مطلقه باشخص د د يكرى

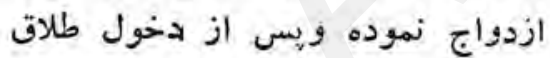
كردد ، مى تواند بازوج اول ازود ازدواج

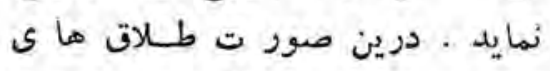
قبلى از اعتبار سا قط ، زوج مجدوداً صلاحيت سه طلاق راكسبمينماين.

\section{- 100 ماده}

هركاه زوج در حال مرض موت،

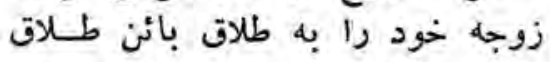

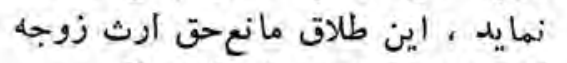

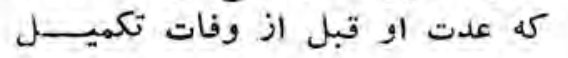

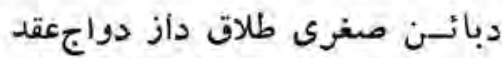

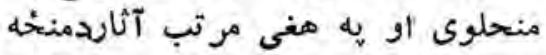

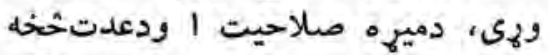

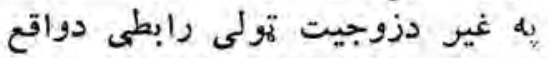

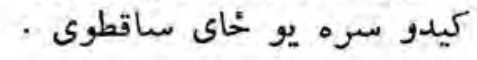

$$
\text { - lor }
$$

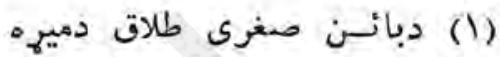

سره دطلاقى شوى بندخى دازئ داز دواج

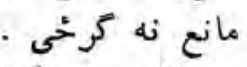

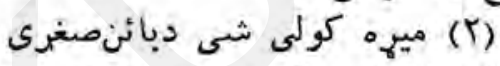

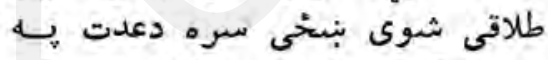

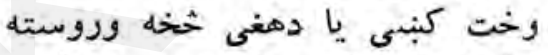

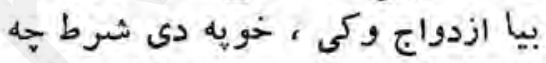

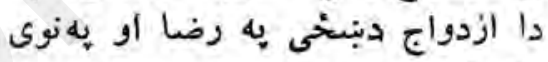

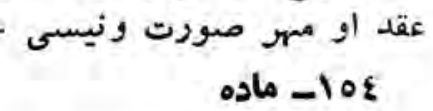

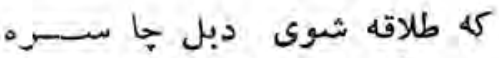

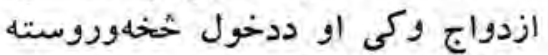

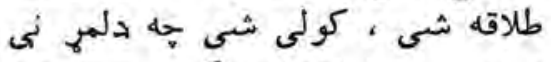

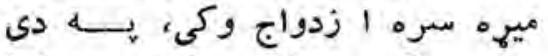
صورت كبنى مخكنى طلاقونه ساقط او ميهه بيا ددرى طلاقو صلا حيت طيت

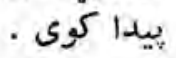

$$
\text { كادم } 100
$$

كله ميره دمركت دمرض يه ماده حالت

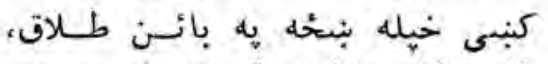

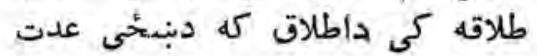

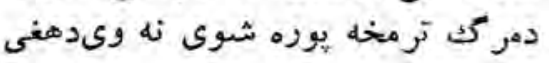




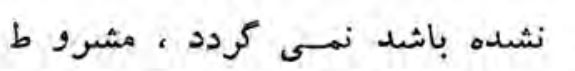
براينكه مطلقه از وقوع طلاق تاوفات به سبب ديكرى از حق ميراثمحروم

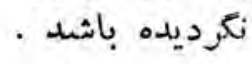

$$
\begin{aligned}
& \text { فرع حهارم - خلع } \\
& \text { ماده }
\end{aligned}
$$

دمير اث دحق نه مانع كيب.ى، خويهدى شرط خهه طلاقه شوى دمر كت تروخته

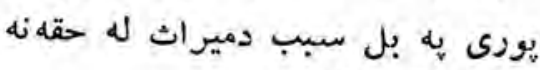

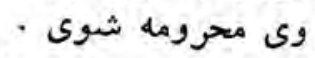
خلورمه فرعه - خلع 107 107

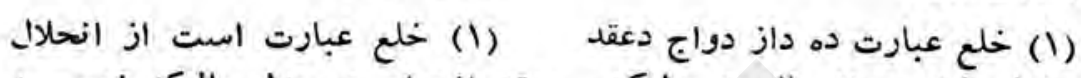

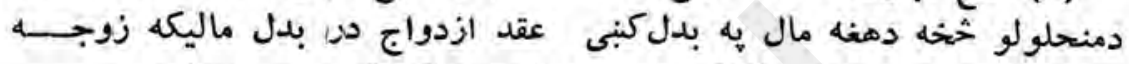

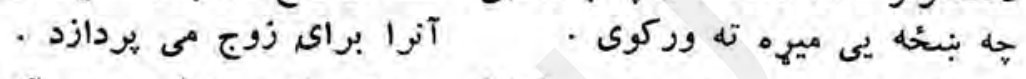

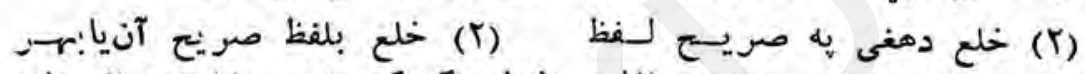

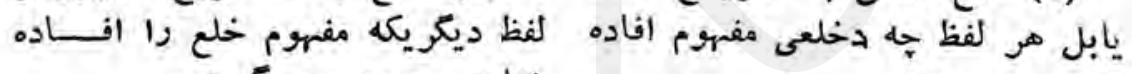

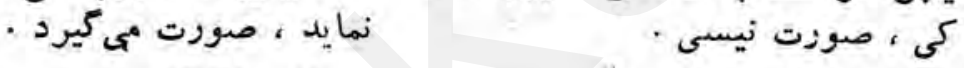

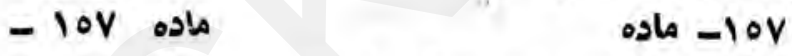

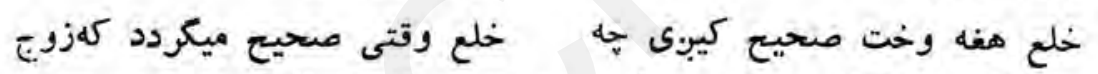

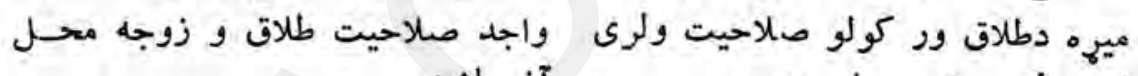

$$
\text { - 101 ماده }
$$

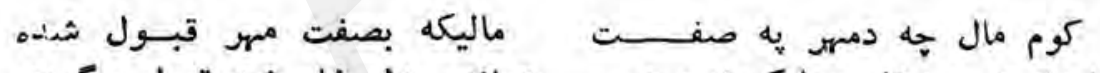

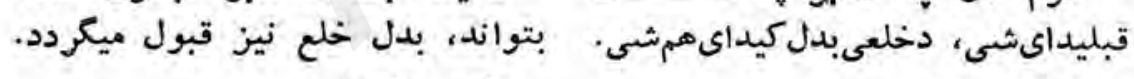

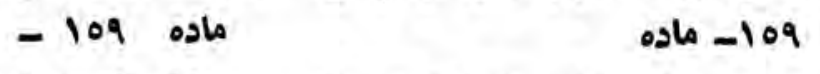

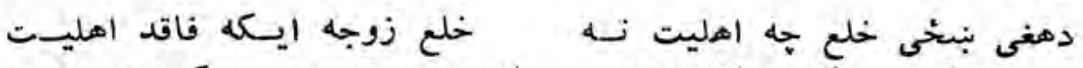

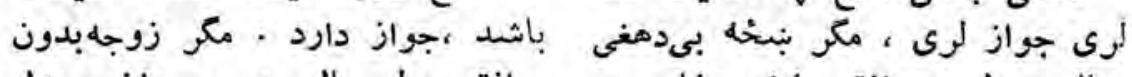

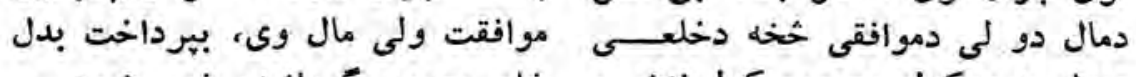

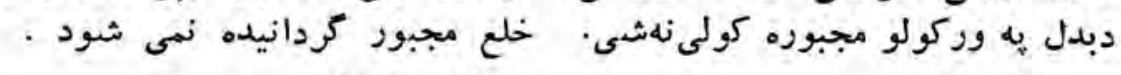

$$
\text { - 17. ماده مجورة }
$$

$$
\text { - } 17 \text {. }
$$

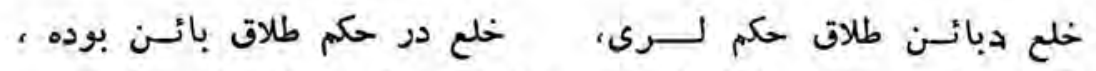

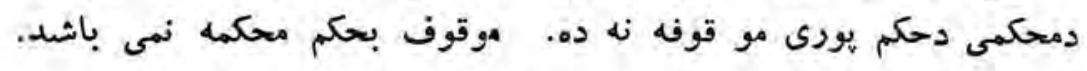




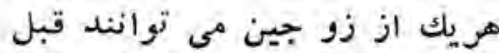
از قبولى طرف مقابل از ايجاب خو خو - رجوع نمايد

\section{-}

دزوجينو شخه هريو كولى شىى خها دمقابل خوا دقبلو لو تورينه

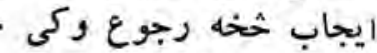

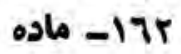

هر كاه خلع در بدل مال معين ماديغير

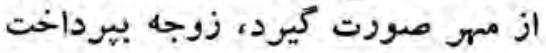
آن مكلفكرديده، مطالبهديكرى ناشيى

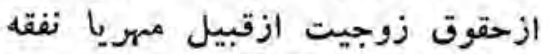

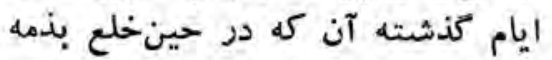
يكديكر داشته باشند، صورت آند درفته نمى تواند

\section{ماده}

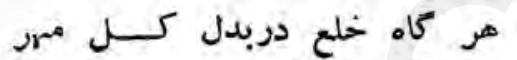

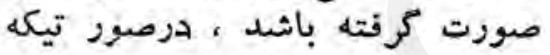

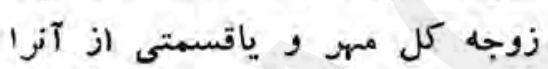
تسليم شده باشد ، مكلف است تاند

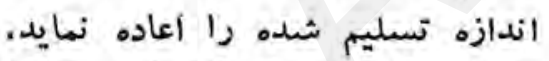

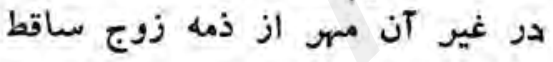

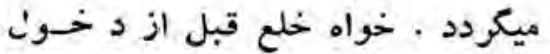

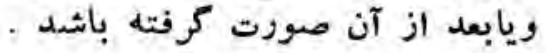

\section{ماده}

مر كاه بدل هنعام خلــ تعييـن نشده باشد ، جميع حقوقزوجيت از ذمه زوجين ساقط كرديده، زوج نمى تواند آنجه را زوجه تسليم شده از

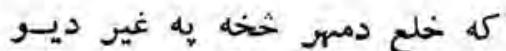

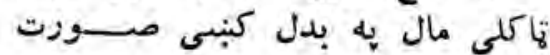

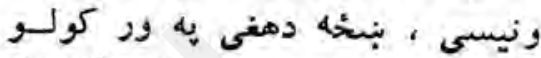
مكلفه ده ، دزوجيت دحقوقو خخهيله

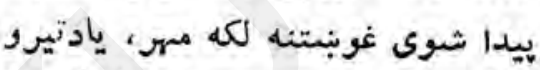

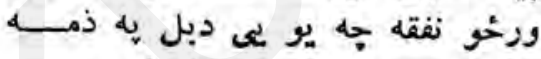

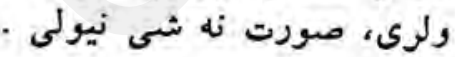

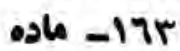
كه خلع دتول مهر بيه بدل كبنى شوى وى به هنه صورت هنه

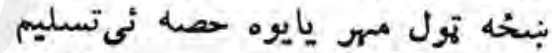

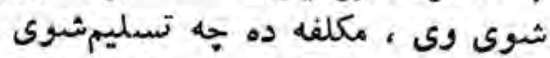

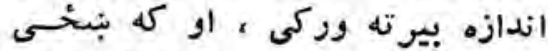

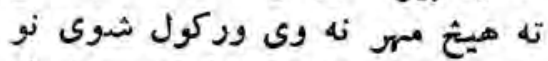

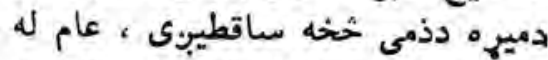

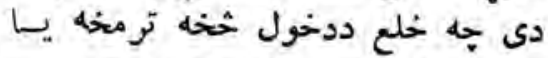

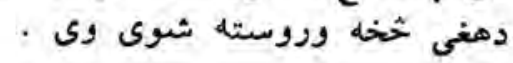

$$
\text { ك }
$$

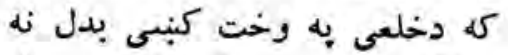

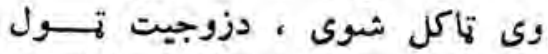

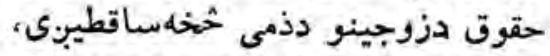

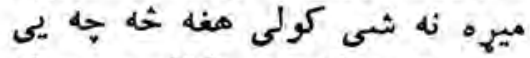

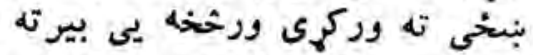

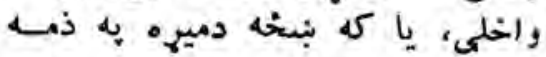


او استر داد يازوجه آنجه را بر ذمه نمانه

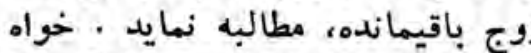
اين خلع قبل ازو دخول صورت كرفته باشد يابعد از آن آن آن

\section{- 170 -}

هر كاه بدل هنأمام خلع نفى شده

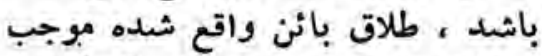

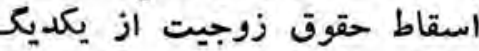

$$
\text { نمى مكردد حتون }
$$

\section{- 177 -}

هركاه زوج بدلخحلع را بغيرحتى

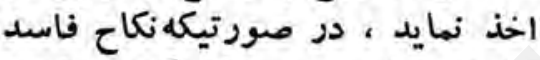

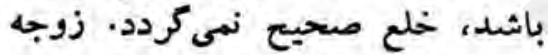

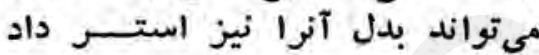

$$
\text { - } 178 \text { os }
$$

هو كاه بدل خلع قبل از تسليم

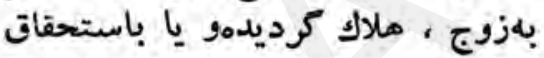

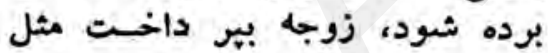
ياقيمت آن مكلف مىباشد موده ير داخد

$$
\text { - } 171 \text { ماده }
$$

درخلع نفقه عدت ساقط نمىكردد. مكر اينكه زوجين هنكامخلعصراحتآ نهئ به اسقاط آن موافقه كرده باشند .

$$
\text { - } 179 \text { os }
$$

هر كاه اجرت شير دادن طفل در مدت رضاع يا حفاظت وى به به شهول نفقه دريك مدت معين ازطرف زوجات ونه

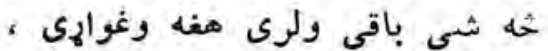

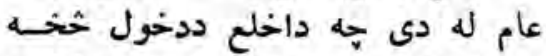

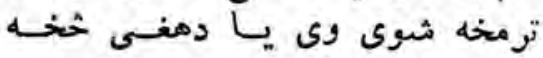

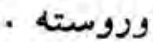

$$
\text { و } 170
$$

كه دخلعى يه وخت كنبي وخى دخلعى

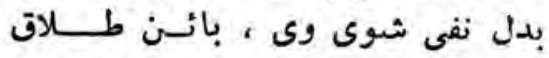

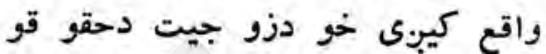

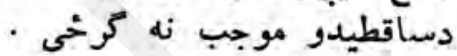
177

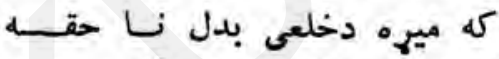

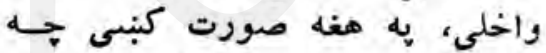

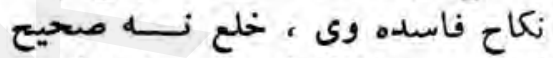

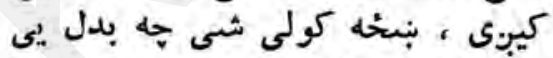

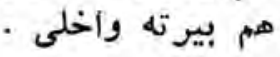

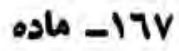

كه دخلعى بدل ميره تهدتسليميدو

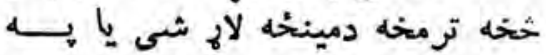

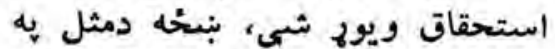
وركولو يا دهغى يه قيمت مكئ مكلفه ده. 17 ا - ماده

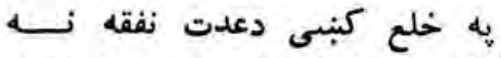

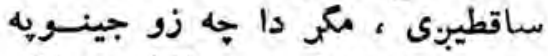
صريح هول دهغى يه ساقطيدومي دوافقه جيه - كرى 179 179

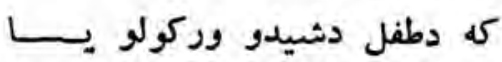

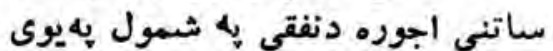

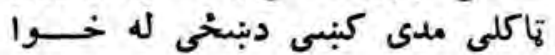




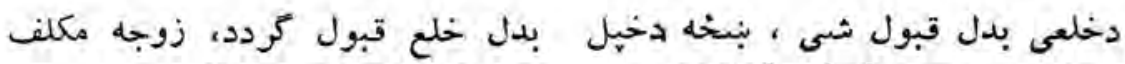

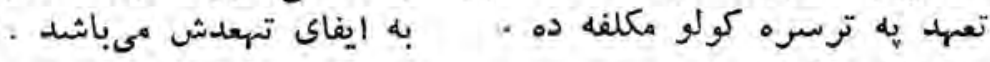
- IV. . IV.

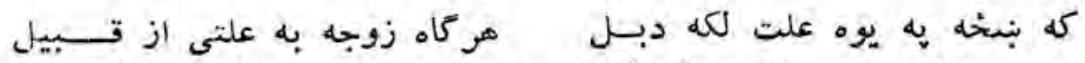

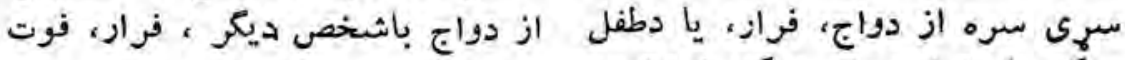

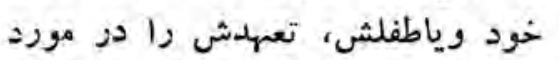

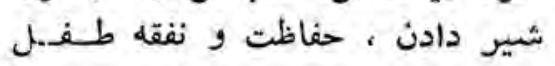

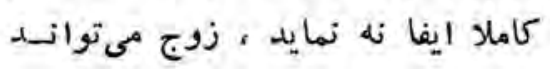

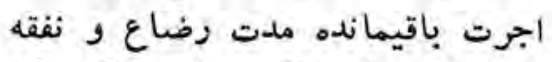

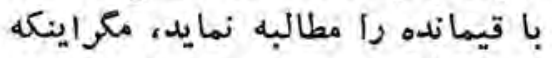

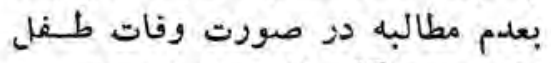

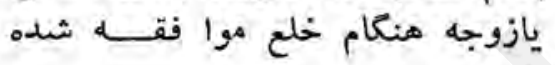

\section{- IVI ماده}

هركاه قبل از ولادت ، شير دادن

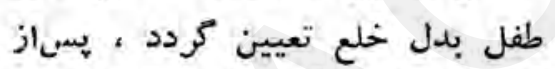

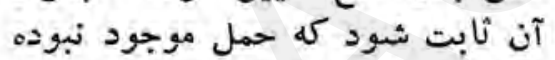

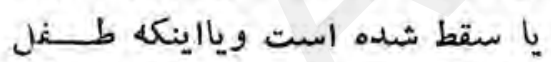

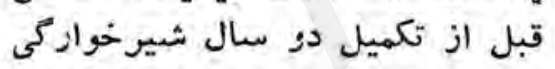

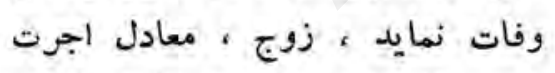

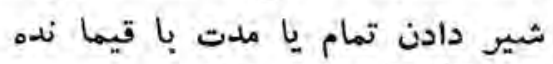

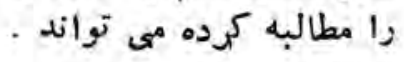

\section{- IVr osto}

زوجه و قتى مىتواند حفا طلـت

طفل را تاسن بلوغ بدل خلع تعيين نمايد كه طفل، دختو باشد. هر كاه

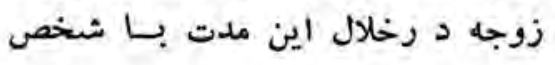

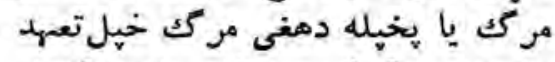

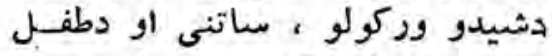

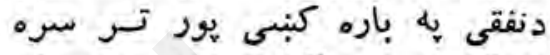

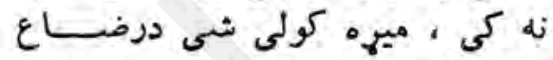

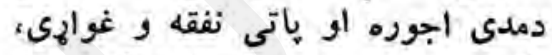

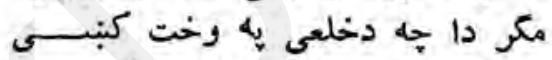

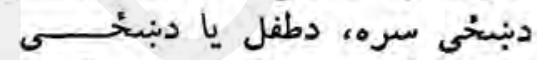

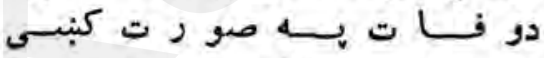

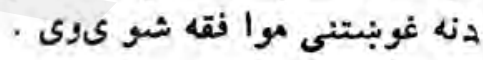
كا

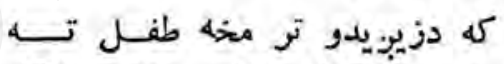

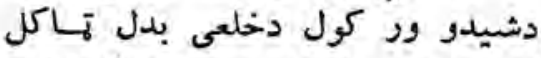
شوى وى ، ترهغيووروسته ثابتهثيى جه حمل موجودنه وو ياسقط شوى

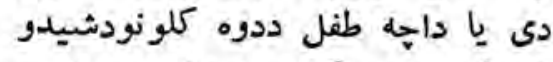

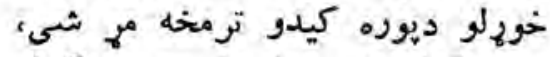

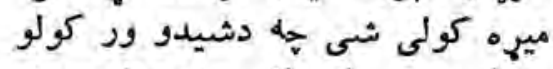

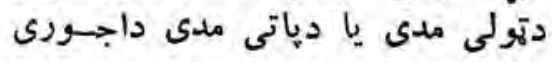
- معادل وغولي مبرى - IVr

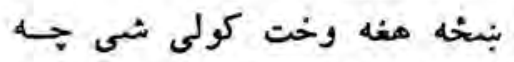
دطفل ماتنه دبلوغ تو عمره يورى وخدي

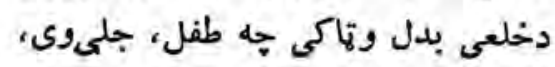

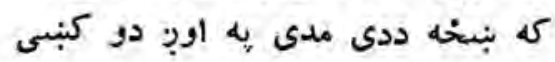




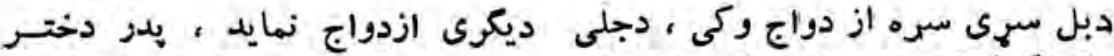

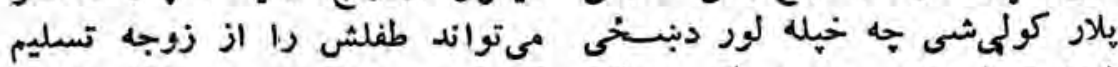

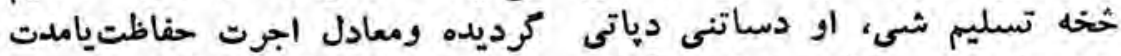

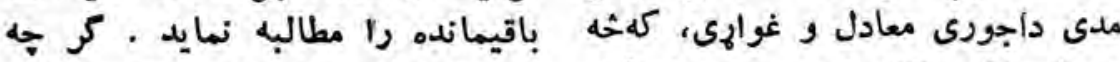

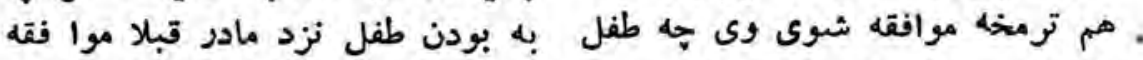

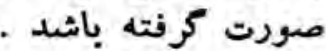
- IVr

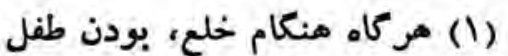

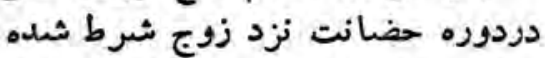
باشد، عقد خلع صحيحوشرط نزو باطل

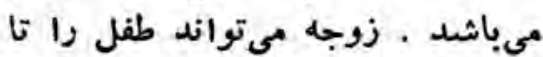
تكميلدوره حضانت نزد خودوراند طفلئت

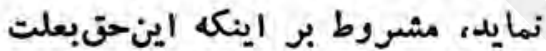

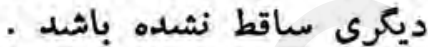

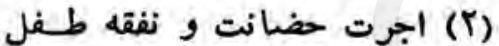

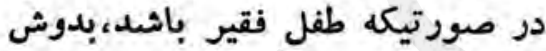

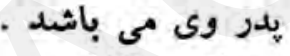$$
\text { - IVE ماد }
$$

زوج نمى تواند دينى راكه برذما دورة زوجهاش دازد، در عوض دين نفقـــ نديه

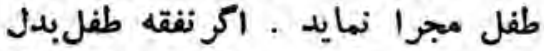

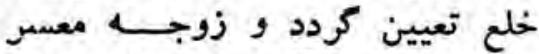
باشد ، زوج مكلف بير داخت نفي نفيه

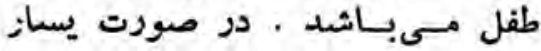

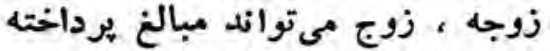

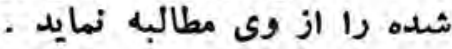

$$
\text { - IVo }
$$

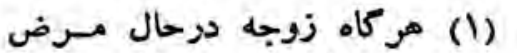
موت بازوج خلع نمايد ، خلع صحيع دواد مـرض

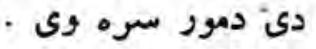

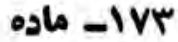

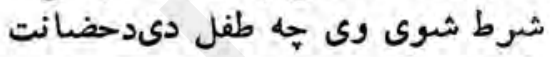

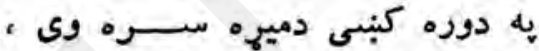

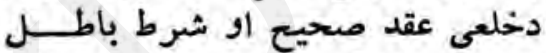

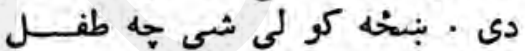
دحضانت ددورى ديوره كيدو نيخ يورى

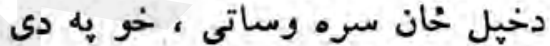

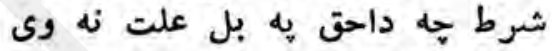
ماقط شوى ماته اجوره اودمغه نفقه ديلاريه غاره ده. اجو (r) كه طفل فقير وى نودوحضانت - IVE

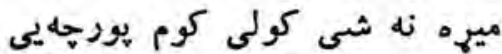
دخهلى بنبخى يه ذمى لرى هغ كنه دطفل

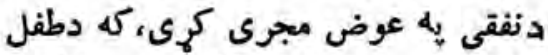

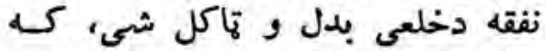

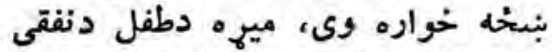

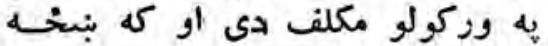

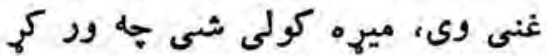

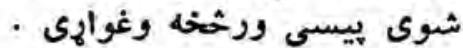

$$
\text { IVo }
$$

(1)

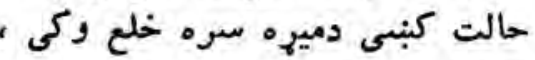


وباثر آن طلاق بائن واتع ميكريد.

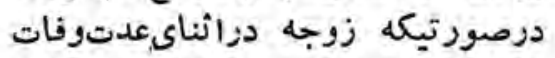

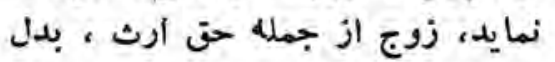

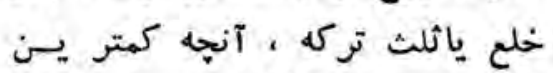

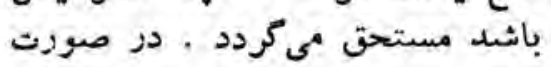

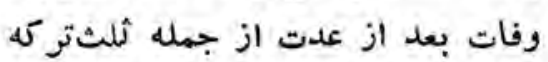

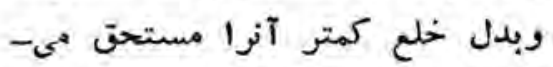
شود .

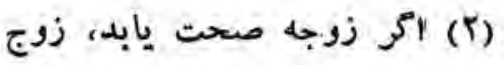

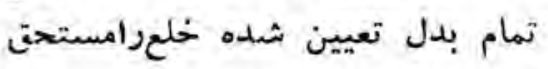

$$
\begin{aligned}
& \text { ميشود . مان } \\
& \text { فرع بنجم - تفوديق } \\
& \text { جزء اول - تفريق به سبي سيب } \\
& \text { - IV7 ماده }
\end{aligned}
$$

زوجه وقتى مى تواند مطا لـبــه

تفريق نمايد، كه زوج مبتلا بهر ضى اعلى

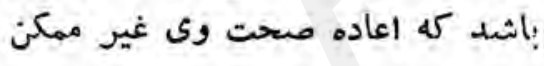

يا مدت طولانى براى معالجه اولازم باشد ، به نحويكه معاشوت بازو ج بدون ضرر كلى متعذر باشد .

\section{- IVV ماده}

هر كاه زوجه هنكام عقد ياقبل آن بعيوب متذكره ماده (IV7) اين قانون واقف بوده يادز صوزتوقوع
خلع صحيعده اودهغىيـه اثر بائسن

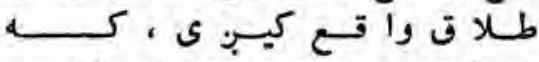

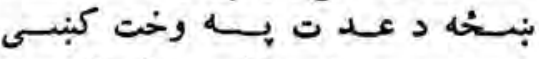

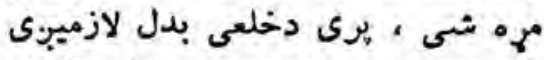

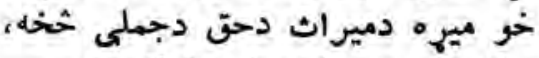

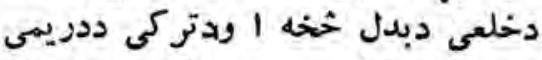

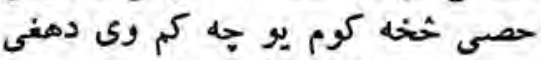

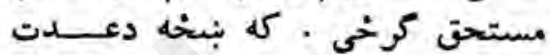

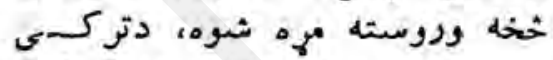

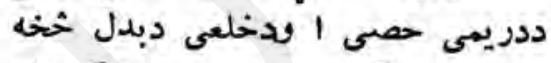

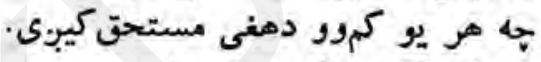

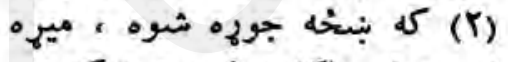

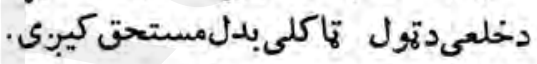

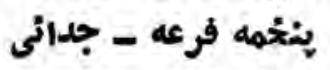

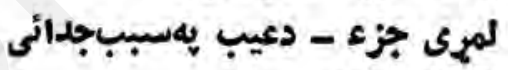

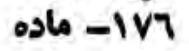

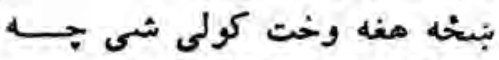

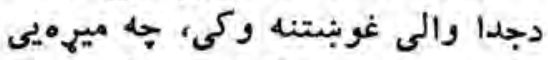

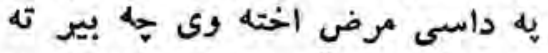

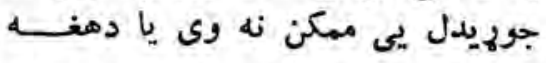

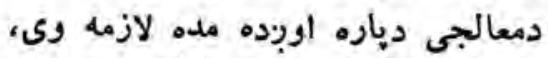

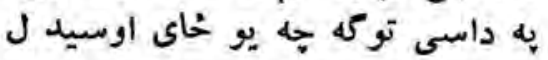
ورسره بي له كلى ضرر خخه نامهن

$$
\text { و }
$$

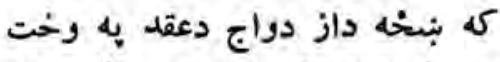

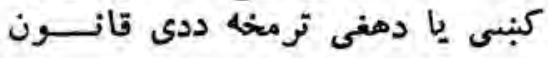

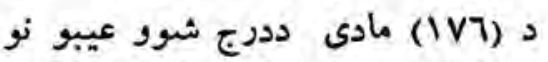
خخه خبره وى يا دعقد خخه ورون دور وريته 
دعيب دواقع كيدو يه صورت كبئى عيب بعد از عقد طور صريحياضنى

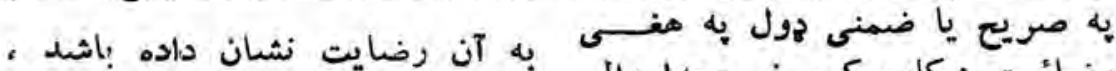

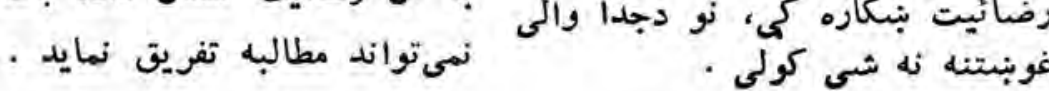

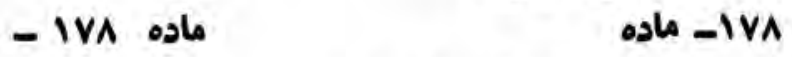

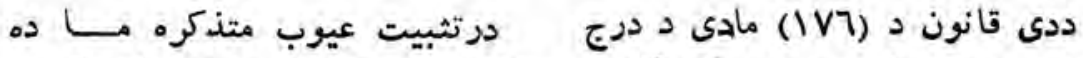

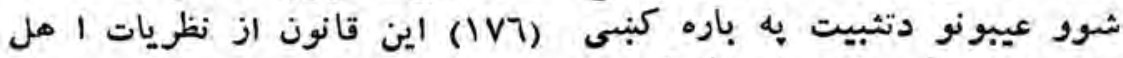

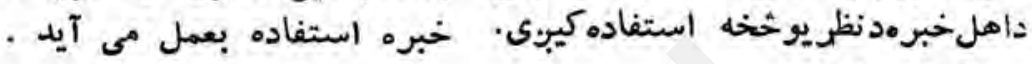

\section{- IV9 ماده}

- I V9

هر كاه عيب از اده نوعى تثبيت مادرد كه عيب له داسى نوعى خخهاتثبيت

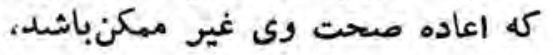

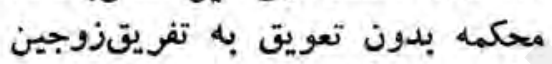

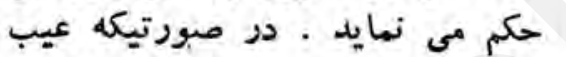

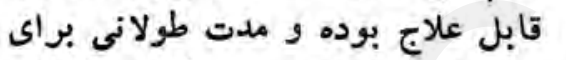

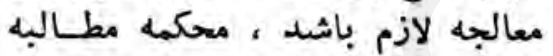
تفريق را تا مدتيكه متجاوزازيكسال

$$
\begin{aligned}
& \text { نباشد بـا تعويق مى اندازد . } \\
& \text { ماده }
\end{aligned}
$$

تفريق به سبب عيب، طلاق باتن

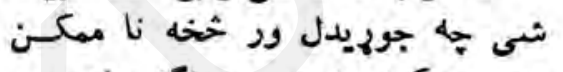

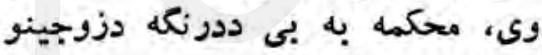

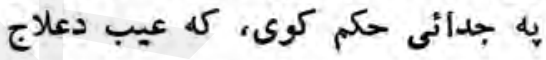

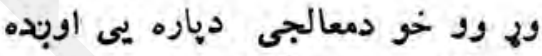

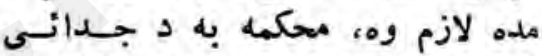

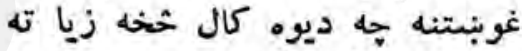

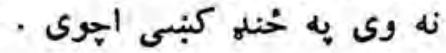

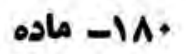

دعيب به سبب جدائى، بائنطلاق

$$
\text { است . }
$$

$$
\text { - IN1 }
$$

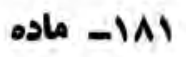

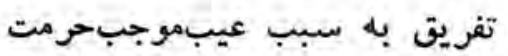

ابدى نكرديده، زوجين مىتوانند بعد بلدي

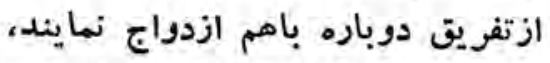

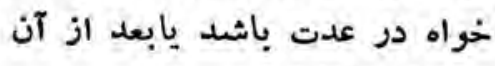

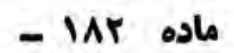

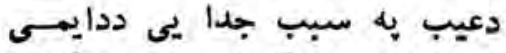

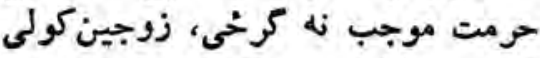

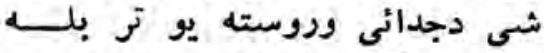

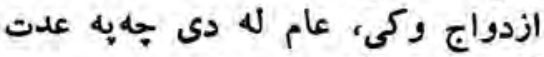

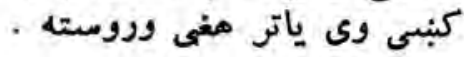

$$
\text { ra }
$$

هر كاه يكى از زوجين كهبه مبره عيب بين آنها تفريق واقع شديدورونات

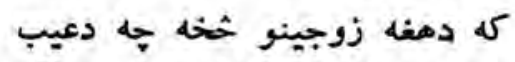

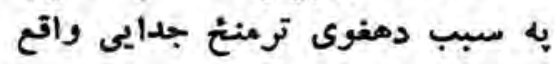




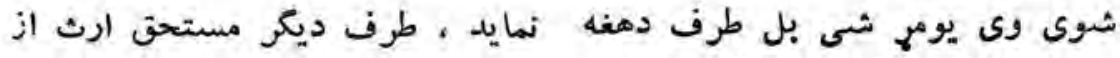

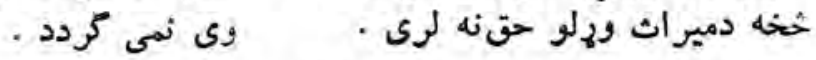
جزء دوم - تفريقبهسبب نردمرد -

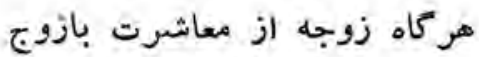

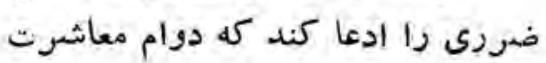
را در حنين حالت بين امثال زورجين

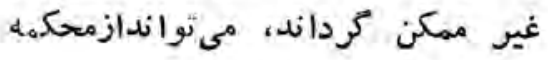

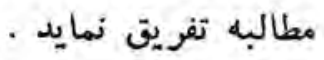
- InE دوهم جزء - دضرديه سببجدائى rar كه بندخه دميه ديه ديو خادى اوسيدلو

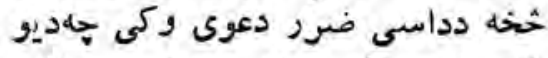

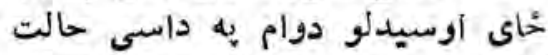

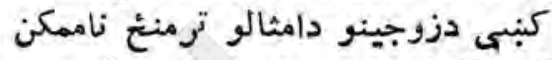

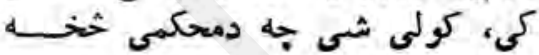

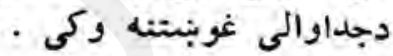
侽 (1) هر كاه ضرر مورد ادعا ثابث كرديده واصلاح بين زو جين صورن صورت

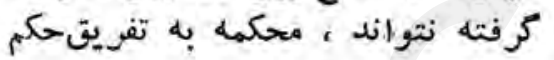
مينمايد كرفيل نتوان رارد) تفريق ، حكم يك طلاق بائسن

(1)

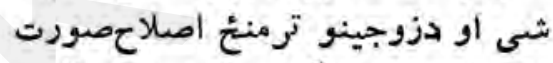

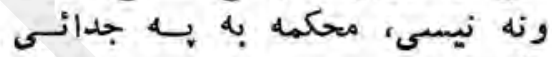
حكم كوى نه (r) جدانسى ، ديوه بانسن طلاق را دارد .

\section{- 110}

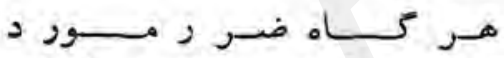

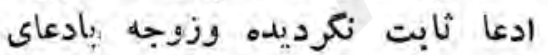

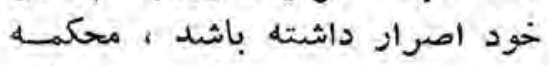

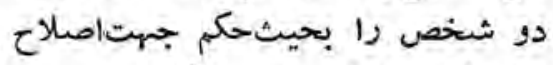
مين زوجين تعيين مينمايد راجيد

$$
\text { ماده }
$$

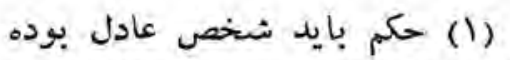

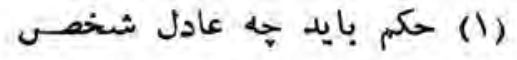

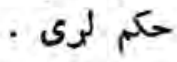

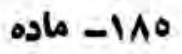

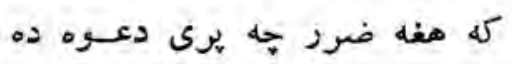

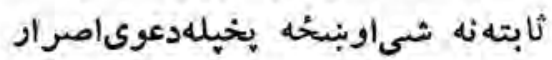

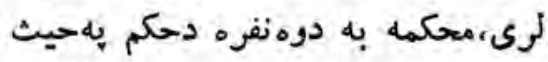
دزوجينو ترمنخ دصلحى ديارهتاكى يكى از اقارب زوج وديكرى إزاز أقارب

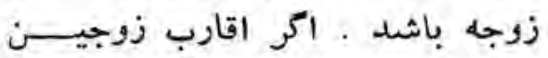

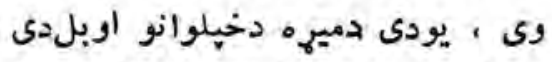

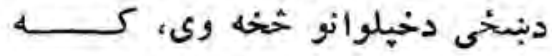

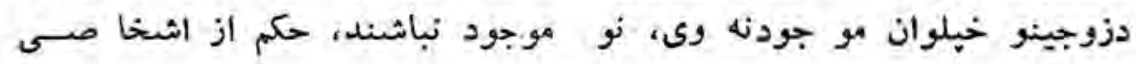


تعيين ميكردد كه از احوال زو جين معلومات كافى داشته به اصله اصلاحبين زوجين قادر باشد بافي

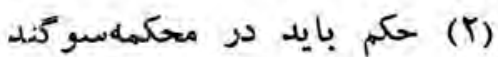
ياد نمايد كه وظيفه خودرا بعسدان وامانت دارى ايفا مى كند . ماده

\section{- IAV ماده}

اشخاصيكه بحيث حسهم تعيي-ن

ميشوند ، بايد علـل اختلاف وطر ق اصلاح بين زو جيسن را تشتيمس

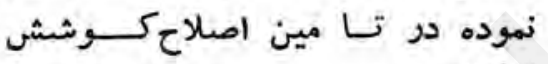
نمايند ن موده

$$
\text { - IAA }
$$

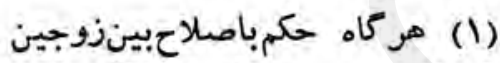

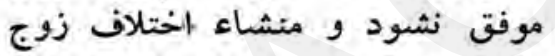

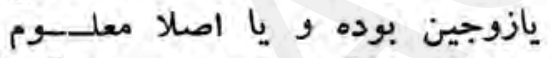
نباشد ، محكمه به به تفريق بين آنها حكم مينمايد

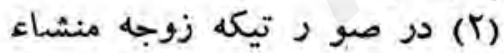

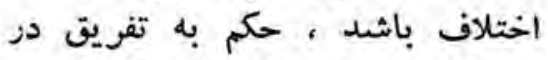
بدل كل مهر و ياقسمتى ازآنتصهيم

$$
\text { مى كيرد . ماد . }
$$

$$
\text { - 1119 مادم }
$$

(1) هر كاه در نظرياتاشخاصيكه

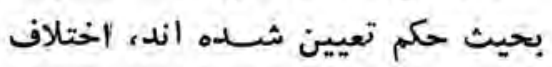

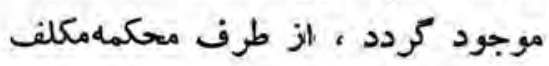
به تجديد نظر ميكردند .
حكم بنه دداسبى اشخخاصو دجملــى

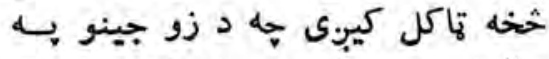

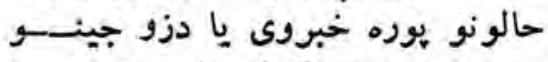

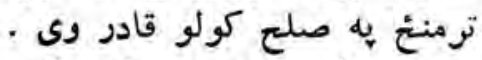

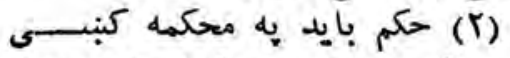
قسم وكى جه خيله وظيفه به به به عدل

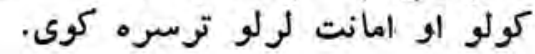

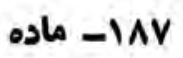

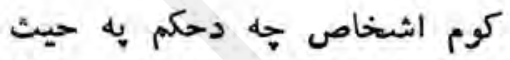

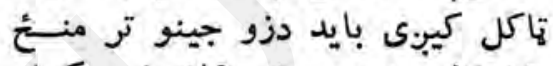

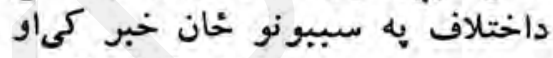

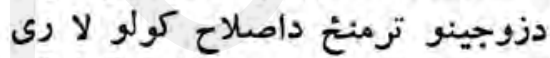

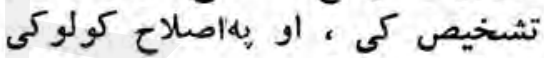
دى كوشش وكى .

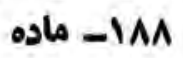

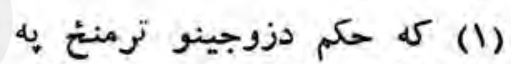
اصلاح كولو موفقنه شيى دوجينو داختلاف ترمني

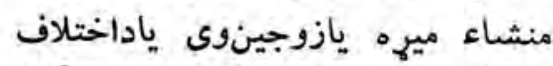

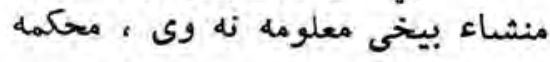

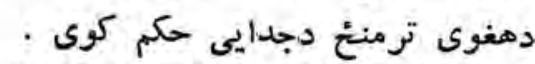
(T)

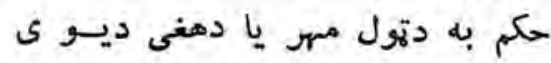

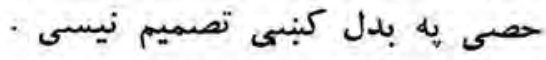

$$
\text { 11119 ماده به بدل }
$$

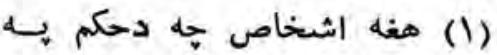
حيث تاكل شوى دى كله دهغوى به به ديه

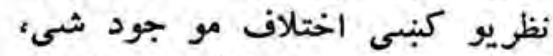

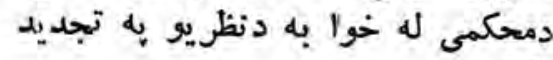
• مكلف كمينى له 
(r) دزصورث دوام اختلافمحكملمه

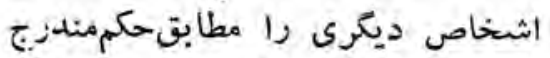

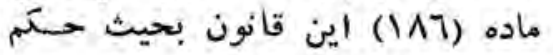

$$
\text { تعيين مى نمايد . ماده }
$$

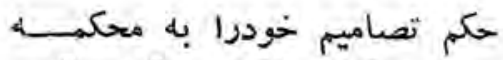

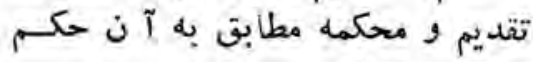

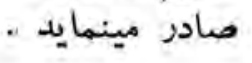

جزء سوم - تفريق به سببعدم انفاق

$$
\text { ماده }
$$

هركاه زوج از اداى نفقه امتناع

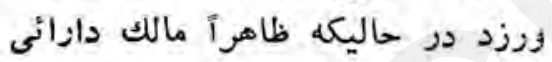
نبوده و عجز وى از اداى نفقه نيز

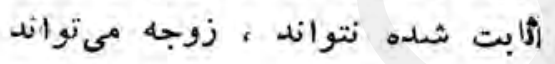

$$
\begin{aligned}
& \text { طالبه ثفريق نمايد } \\
& \text { - ماده }
\end{aligned}
$$

هركاه زوج عجز خودرا ادم اداى

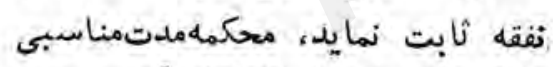

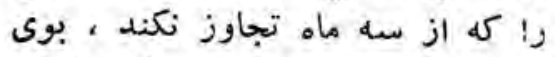

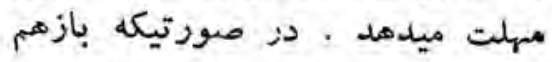

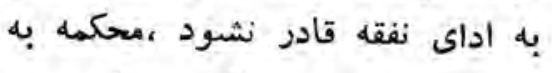
تفريق بين زوجين حكم مينمايد ،

$$
\text { - }
$$

تفريق بين زو جين كاده به سببـ

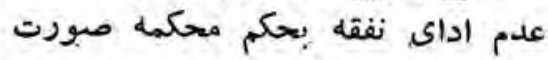

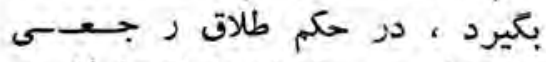

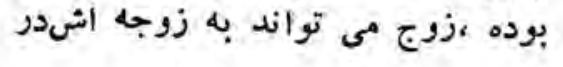

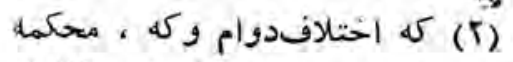

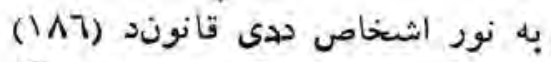

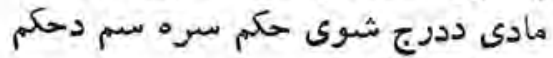

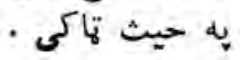
- 19.

حكم به خيل تصميمونه محكمى ماده

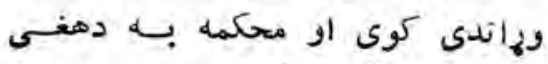

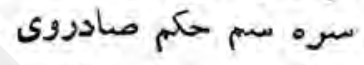

دريم جزء - د دنفقى دنه ور كّونو

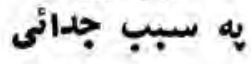
(191

كه ميه مه دنفقى دور كولو ماده خخهئان

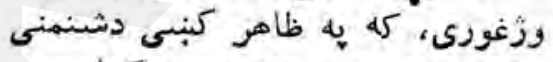

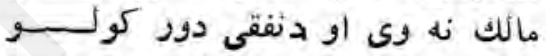

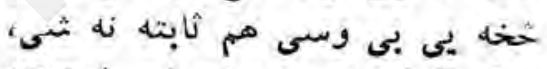

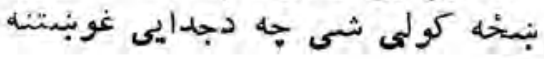
. و

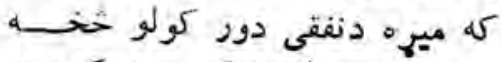

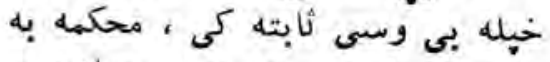

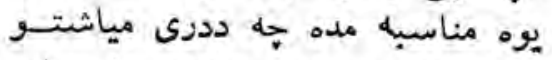

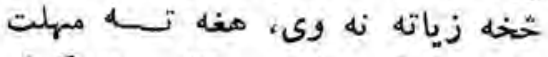

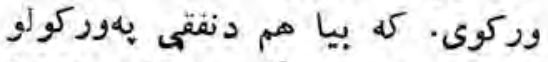

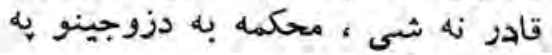
جدائى حكم كوى نه

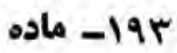

جدأيىجه دزوجينو ترمنخ دنفقى دنه داده

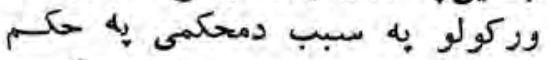

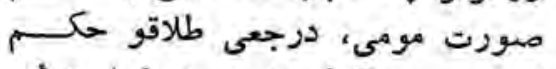

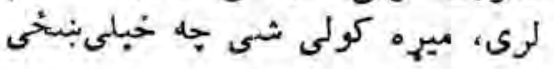




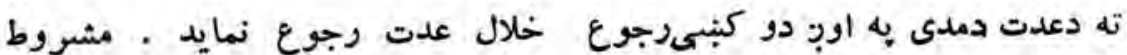

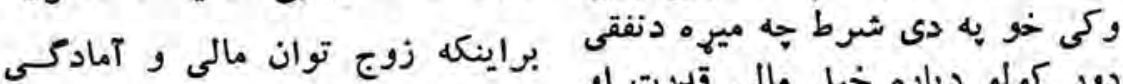

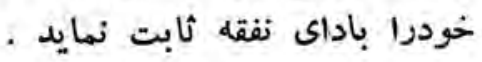

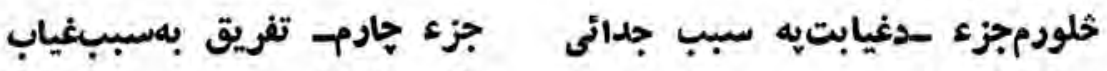

$$
\text { - 19ع ماده }
$$

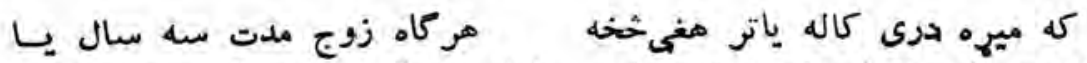

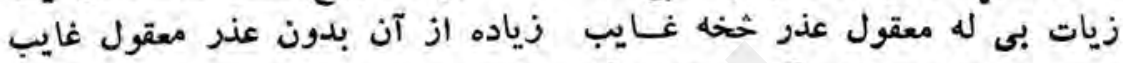

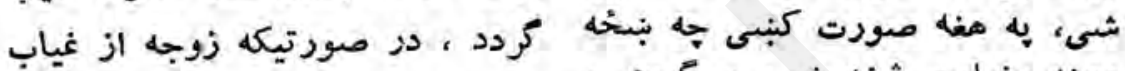
وى متضرد شود ، مىتواند ازمحكمه

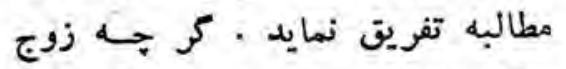

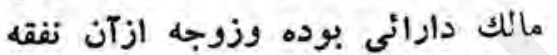

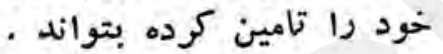

$$
\text { - } 190 \text { os }
$$

(1) در صورت غياب زوج،محكمه بعداز استماع مطالبهتفريقازجانب

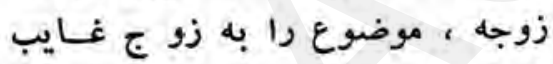

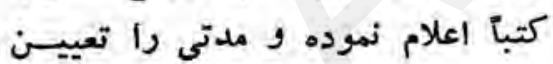

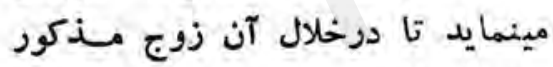
بمسكن فاميل عودت نموده يا زوجه

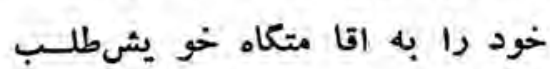
نمايد نود ول (r) در صو ر تيكه زوج غـايب باوجود اعلام محكمه، بدونعذرمعقول

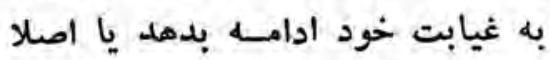
وصول اعلام بهزوجغير مهكن باشد،

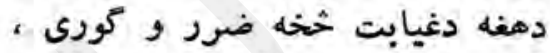

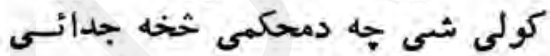

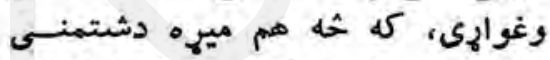

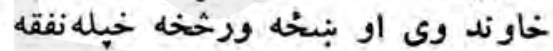

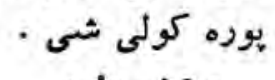
ادوره 190

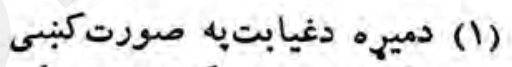

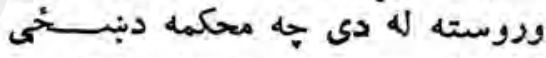

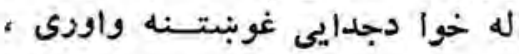
موضوع به غايب ميهه ثله به ليكلى

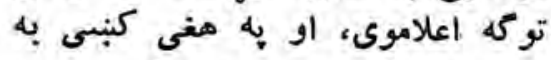

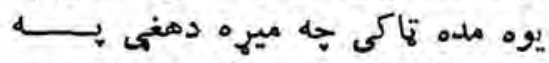

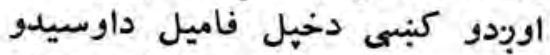
خاى ته بيرتسه رأشى يا خيله بنيخه

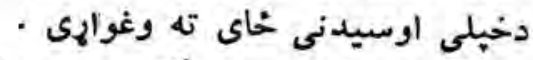

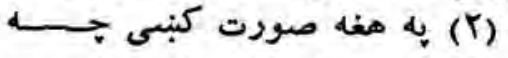

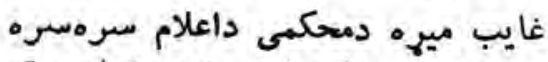

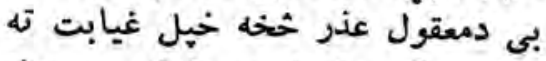

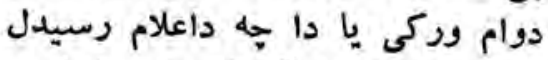

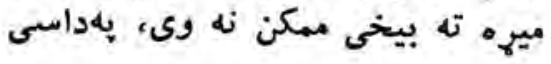


دزجنين احوال ، محكمهل به تفريست

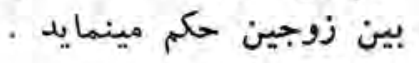
ماده

هر كاه زوج بحكم قطعي محكمه به حبس ده مسال يا بيشتر ازآن محكوم

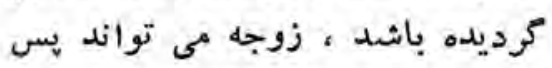
مدت ينج سال مطالبه تفريقنمايد.

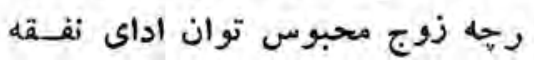

$$
\begin{aligned}
& 1 \text { داشته باشد } \\
& \text { - lar }
\end{aligned}
$$

(1) تفريق به سبب غيابدرحكيم

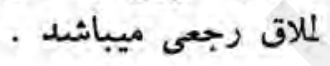

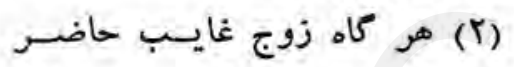

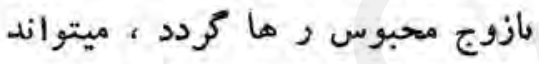

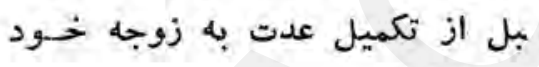

$$
\text { رجوع نمايد }
$$

مبحث نهه - آثار انحلال ازدواج

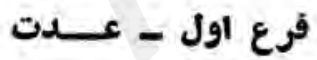

$$
\begin{aligned}
& \text { ماده }
\end{aligned}
$$

عدت عبارت از ملد آت معينيست كأه النقضاى آن تمام آثار مر تبهازدوات معين

$$
\text { ازبين ميرود - ماده }
$$

حالو نو كبنى به محكمه دزو جينو

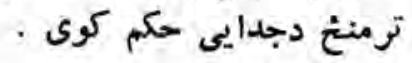
مادم

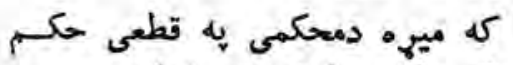

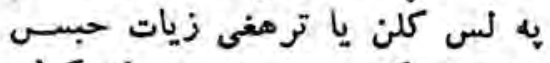

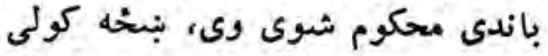

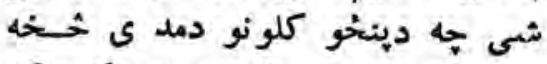

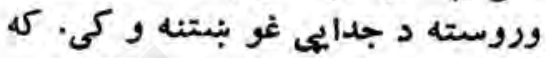

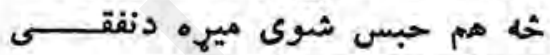
دور كولو قدرت ولرى مون ميره

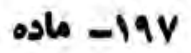

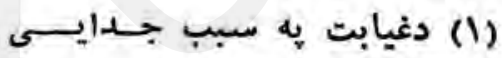

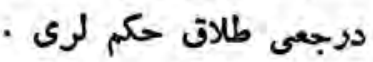

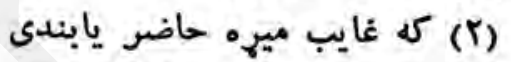
شوى ميهه خلاص شى ، كولى ثى

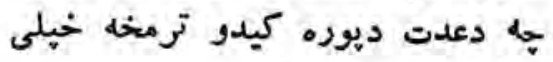
نبشخى ته رجوع وكلى دونى نهم مبحث ـ داز دواج دمنحليدلوآنار

$$
\begin{aligned}
& \text { لمهى فرعه - عدت مهن } \\
& \text { ه }
\end{aligned}
$$

عدت ديوى تاكل شوى مدى شخه

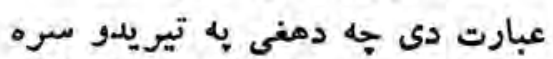

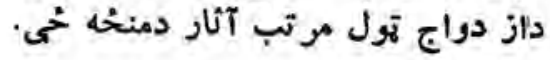

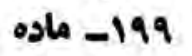

(1) دعدت ديوره كيدو تو مخــا

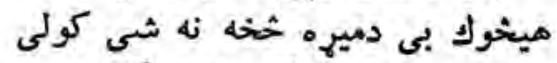

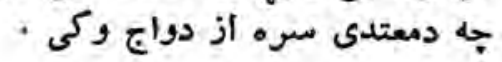


لا مارك در موارد ذيل عدت بوزوجه

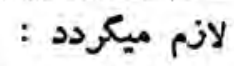

ا- در صو رتيكه تفرديق بـــين زوجين در نكاح صحيح يافاسد، بعد وريك

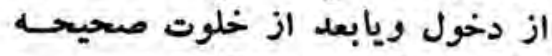

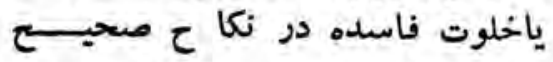
صورت كرفته باشد . خواه 1 يسنا تفريق باساس طلاق رجعى ، بائن

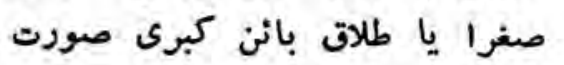
كرفته باشد مات طال

r- در حاليكه تفريق به بـ سبب لعان ، عيب ، نقصان مهر، خيــار

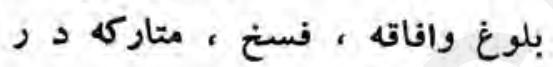
كاح فاسد ياوطى به شبrه

$$
\text { كرفته باشد . ماسد . }
$$

$$
\text { - ماده }
$$

هركاه زوج در نكاح صحيح قبل ازدخول و يابعد از آن وفات ورنات ونهايد،

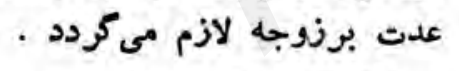

$$
\text { ماده }
$$

في (1) عدت در طلاق و تمام انواع

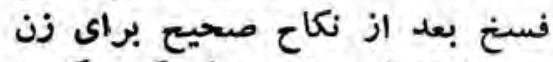

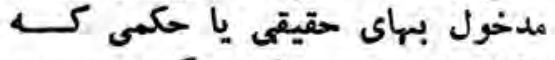

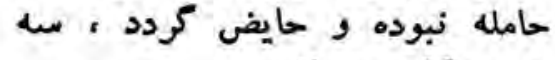
حيض كامل ميباشل حورت كيضيكه در آن طلاقياتفويق

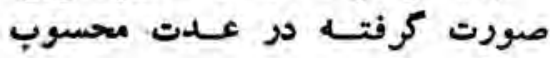

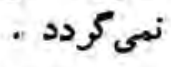

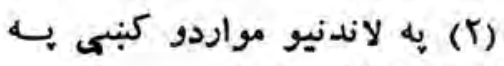

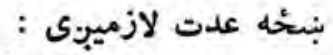

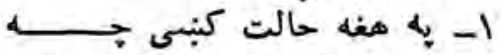

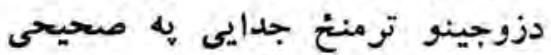
نكاح يا فاسدى نكاح كنبى ددخول

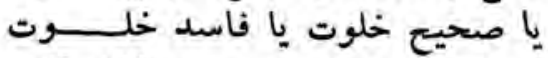

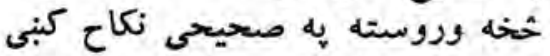

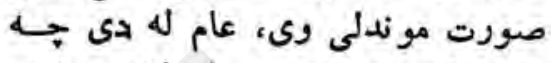

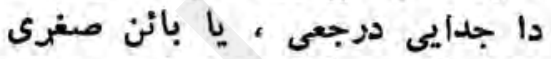
يابائن كبرى طلاق يه دو اساس صورت

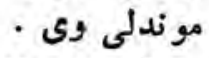

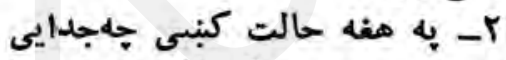

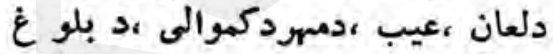

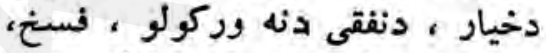

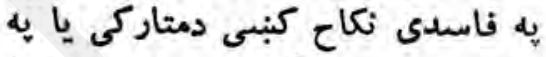

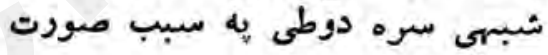
موندلى وى موه . + .

كه ميره هيه صحيحى نكاح كبنى ماده ددخول خخخه ترمخه يا دهغى خخى

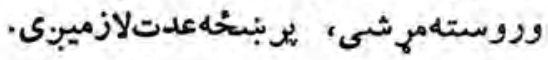

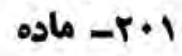

أو (1) دطلاق عدت او دفستخىدتولو انواعو عدت دذاسى بنّخى دياره جهات

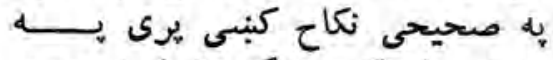
حقيقى يا حكمى تو كه دخول شيوى شوى

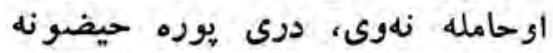

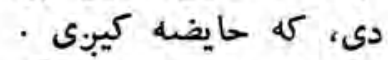

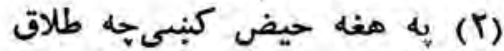
باجدانى صورتموندلى، نهابه حسابيبى. 


$$
\text { - r.r s a }
$$

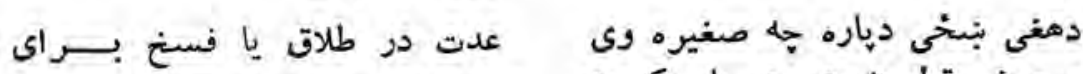

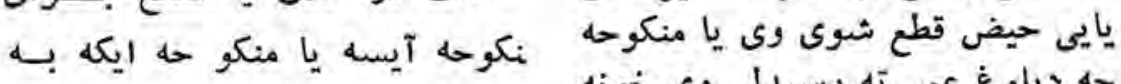
سن بلوغ رسيده و حايض نكرديده

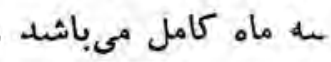

$$
\begin{aligned}
& \text { ماده }
\end{aligned}
$$

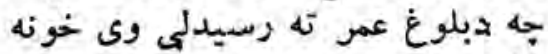

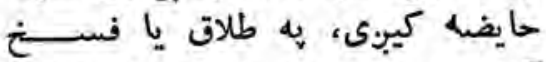

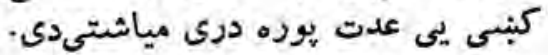

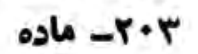

هر كاه مراهقه و آيسه عدتشان

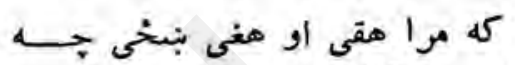
ا بحساب ماه آغاز كرده و قــــن

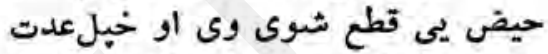

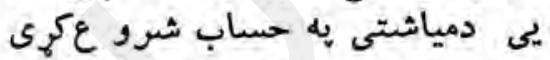
از تكميل سه ماه حايض شوند،عدت

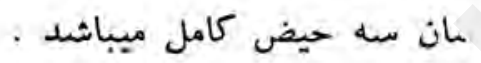

\section{- r.E os}

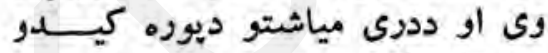

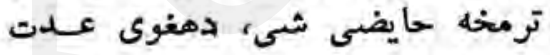

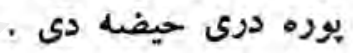

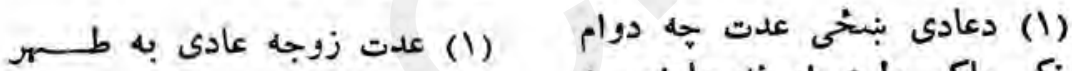

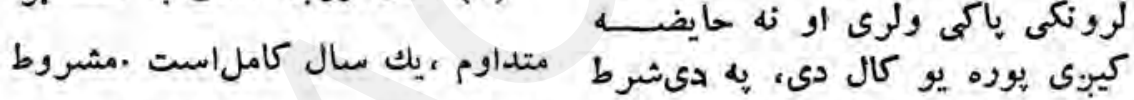

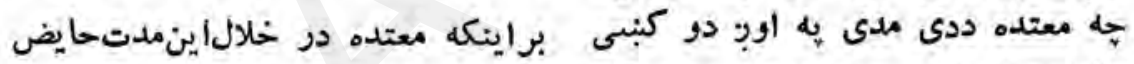

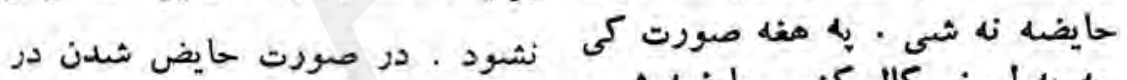
سال اول ، عدت باختم سال دومكه معتده درآنحايض نشلده باشد، تكميل

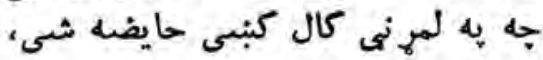

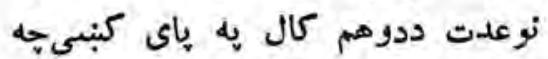

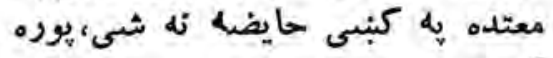
مبكردد

(T) حانفه

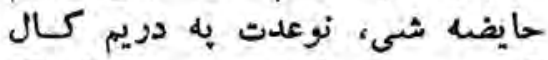

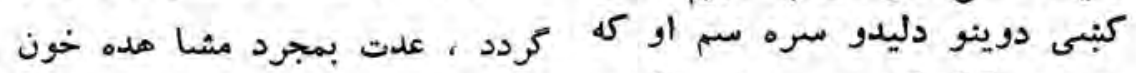

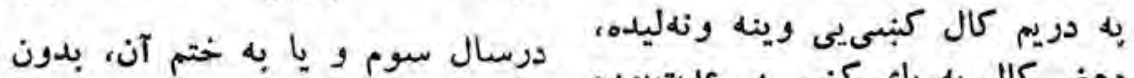

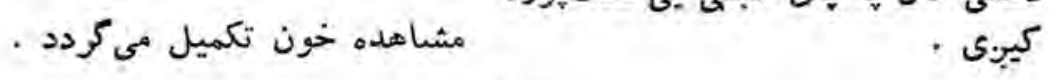




$$
\text { ماده }
$$

عدت زوجه عادى بخون ريسز متداوم كه ترتيب عادت ماهوار خود زا فراموش كوده باشد، بعد ازوقوع طلات ويافسخ،هفتماهكامل ميباشد

$$
\text { ماده T. }
$$

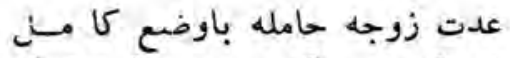
حمل تكميل ميكردد.مشروط باوط برائكه تشكل اعضهاى حمل تماماً وياقسها

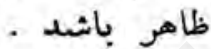

$$
\text { - r.v }
$$

عدت وفات جارماه وده دوزاست،

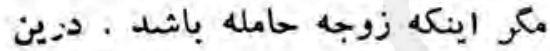

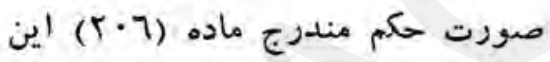

$$
\text { قانون تطبيت ميكردد . ماده }
$$

هو كاه زوج قبل ازه از نكميل عدت

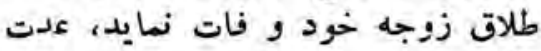

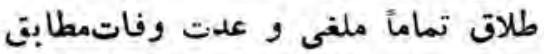

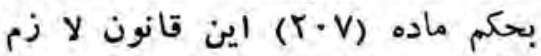

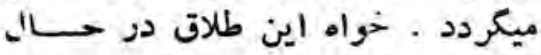

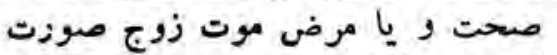

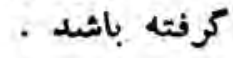

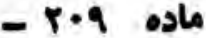

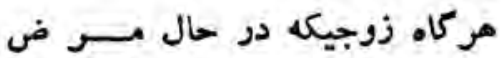

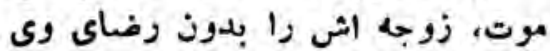

$$
\text { (م) - r.o }
$$

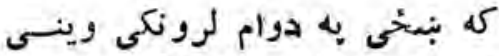

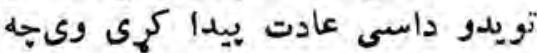

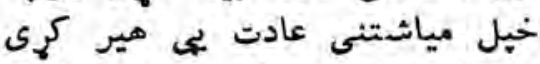

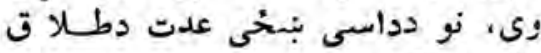

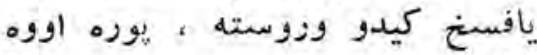
• مياشتى دى

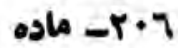

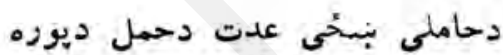

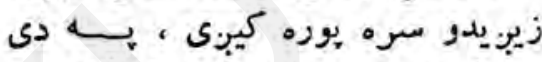

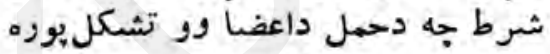

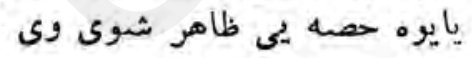

$$
\text { - r.V }
$$

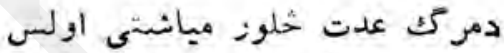

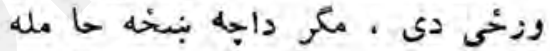

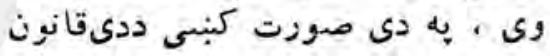

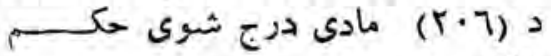
تطبقيبزى ) مآن

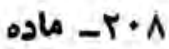

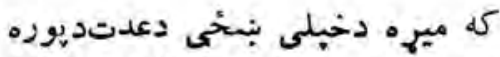

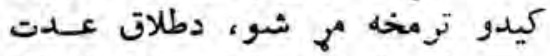
بيخى لغو او ددى قانـون د 2 (V)

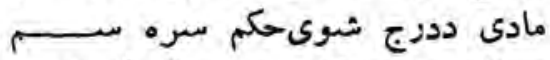
دوفات عدت لازميبِى ، عادي دوى له دئه

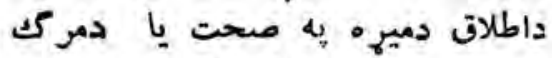
به مرض كبنسى واقع شو ىوى

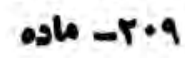

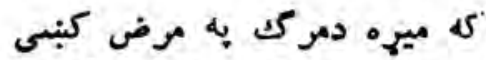

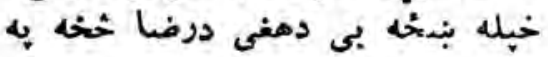




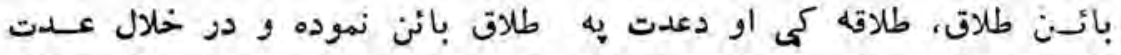

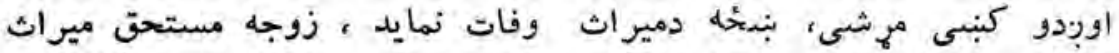

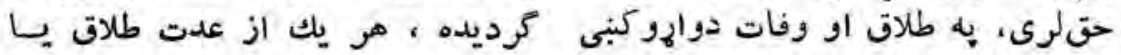

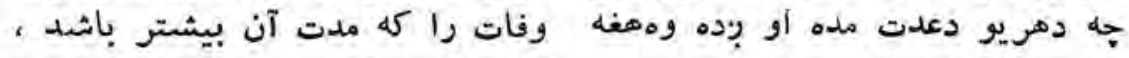

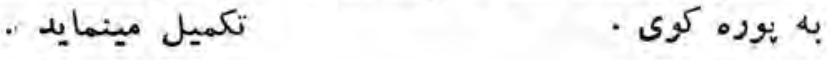

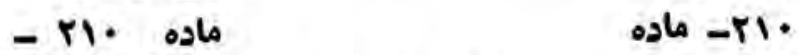

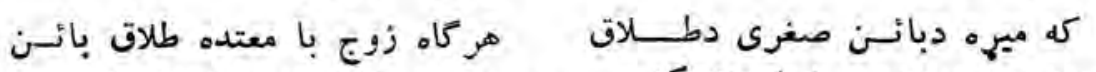

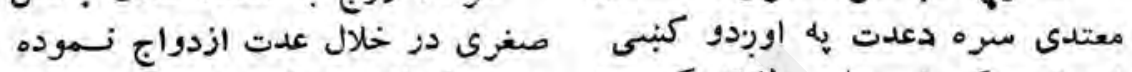

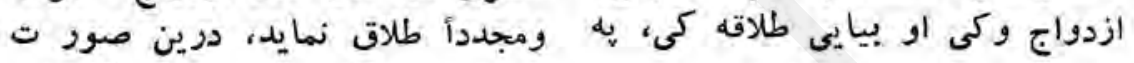

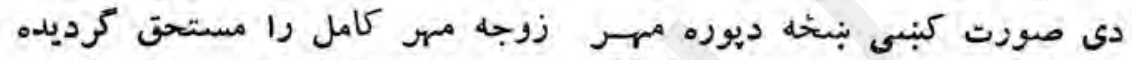

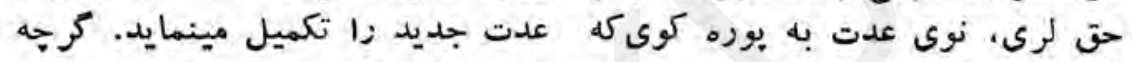

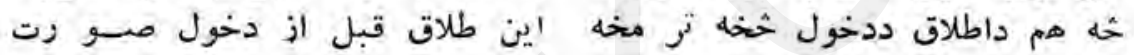
كرفته باشد طلاف قبل

\section{ماده}

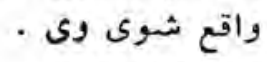

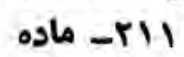

عدت بمجرد وقوع طلاق، وفات.

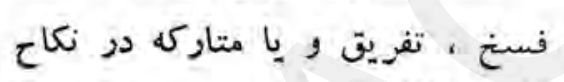

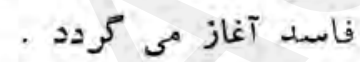

$$
\begin{aligned}
& \text { فرع دوم - نفقه عدت } \\
& \text { - rir }
\end{aligned}
$$

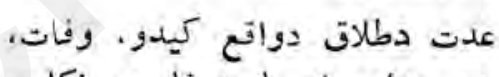

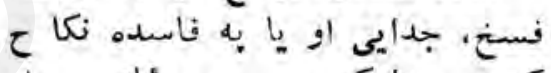

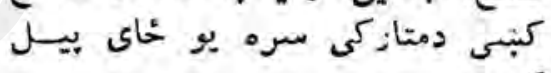
كيبزى كينى

$$
\begin{aligned}
& \text { دوهمه فرعه ـ دعدت نفقه } \\
& \text { rir }
\end{aligned}
$$

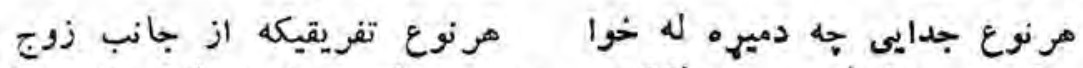

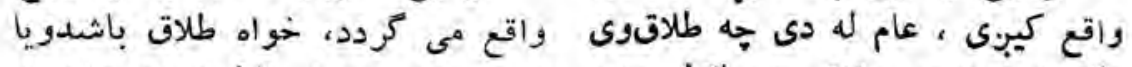

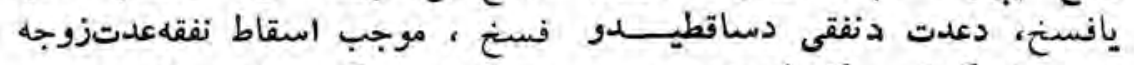

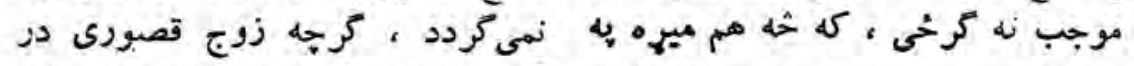

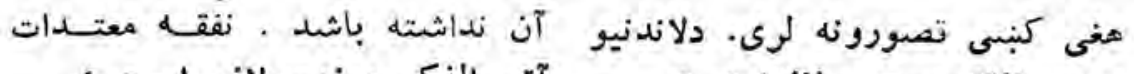

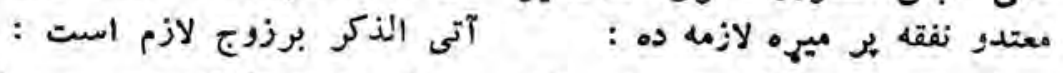

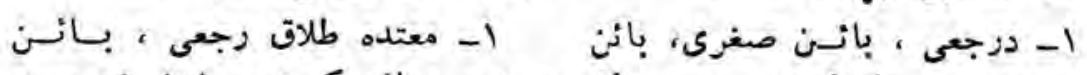

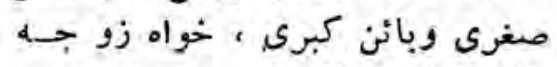
حامله باشد ويانه 


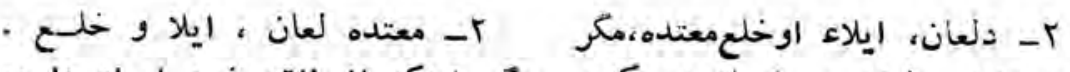

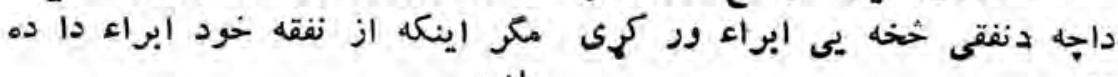
باشد

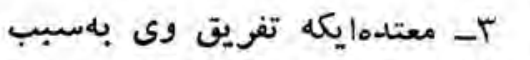

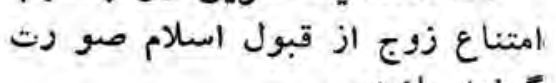

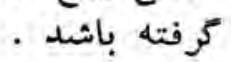

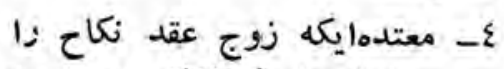

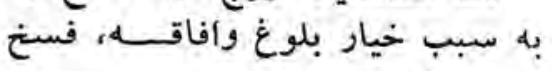

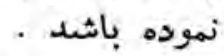

- معتدهايكه تفريق وى باثل باثر

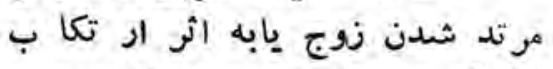

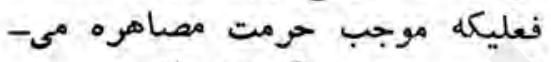
كردد ، صورت كرفته باشيد .

$$
\text { - rir }
$$

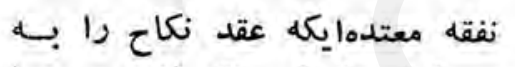

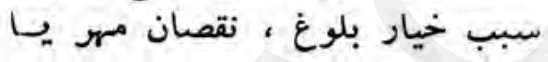

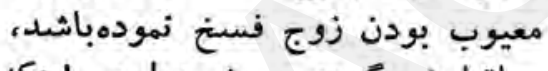

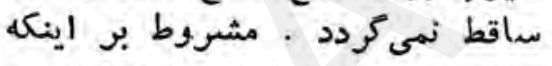
معتده دز مورد فوق قصورى نداثته مئه

\section{- YlE}

هرنوع تفريقيكه به سبب قصوز زوجه و مطالبه وى واقع شدهباشد.

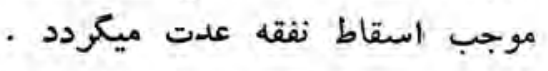

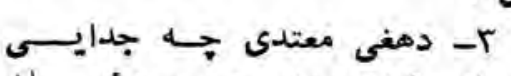

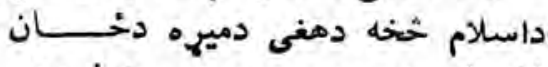

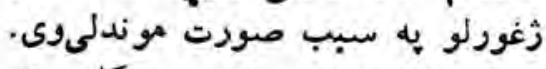

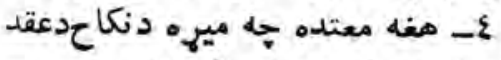

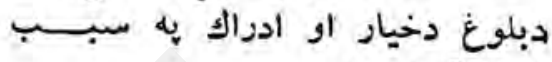

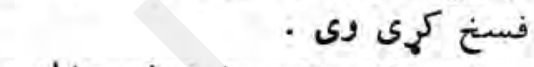

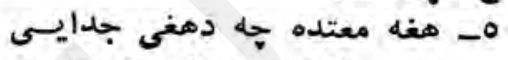

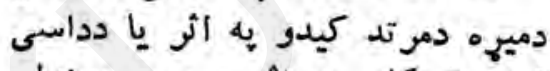
فعل دارتكاب به الثر صورت دور موندلى

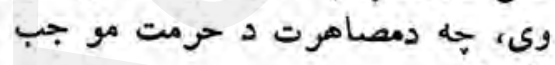
. وكرئ

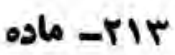

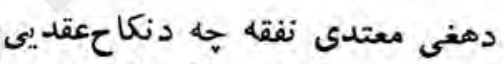

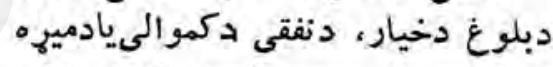

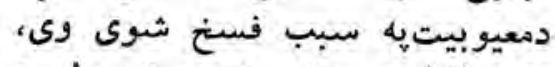

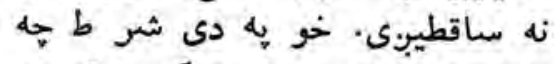

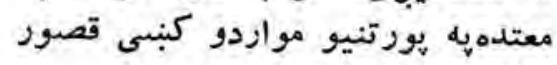
و

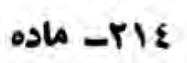

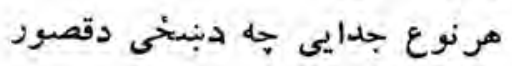

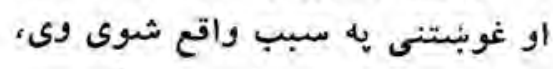

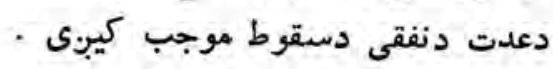

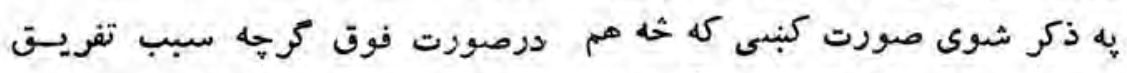

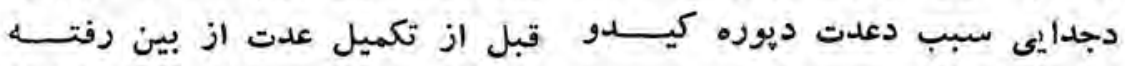

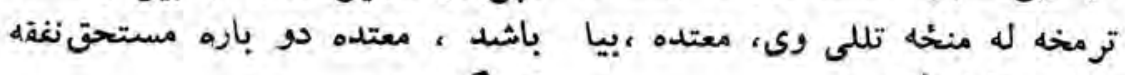
نمى ندئ

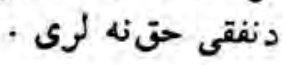


دزصوزت وفات زوج ، زوجهـه

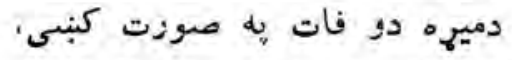

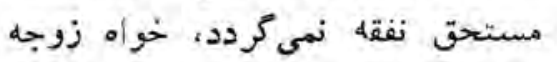
بنبخه دنفقى حقنه لرى عام له دى دونه

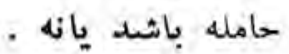

حامله وى او كله نه وى .

ماده

كاد

هر كاه نفقه معتده از طرف زوجه

كه دمعتدى نفقه دميه لهاده له خهوا

تعيين نكرديده و معتده نيز هطاه لبه

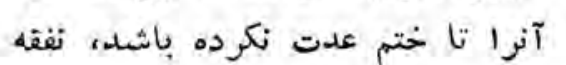

$$
\text { عدت ساقط ميكردد . ناختم عندت }
$$

مبحث دهم - حقوق اولاد

$$
\text { فــر ع او ل - نسبـ }
$$

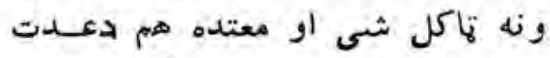

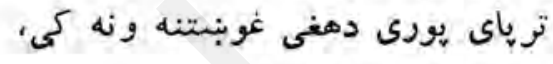

جزء اول - ثيوت نسب در نكاح

دعدت نفقه ساقطيب.ى نول

$$
\text { كسم مبحثـــ داولاد حقوق }
$$

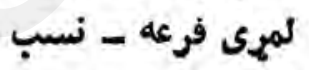

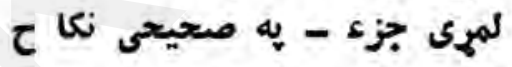

$$
\text { منحيح }
$$

$$
\text { - riv }
$$

كنبى دنسب ثري ئبوت

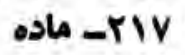

كمترين مدت حمل سشوه سماهواكثر

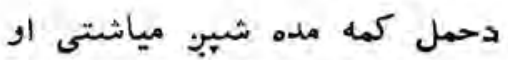

$$
\begin{aligned}
& \text { آن يكسال است . } \\
& \text { ماده }
\end{aligned}
$$

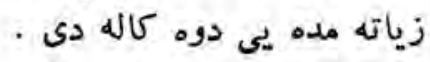

$$
\text { Alו }
$$

طفل هر زوجه دز ازدواج صحيع

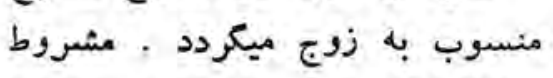

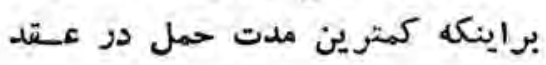

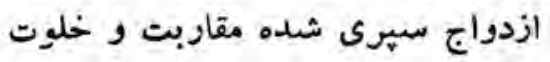
صحيحه بين زو جين ثابت باشهـ .

$$
\text { - ria }
$$

يه صحيع ا زدواج كنبس دهـ مهرى

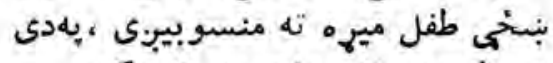

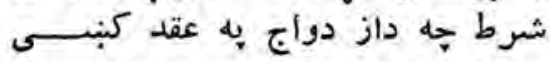

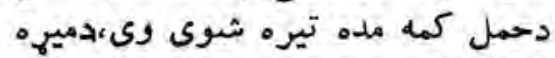

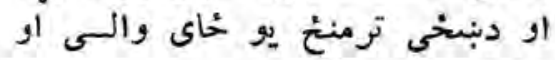
صحييع خلوت ثابت ونئ ون

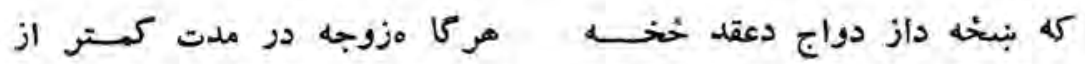

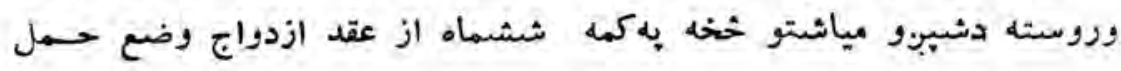


هده كبنى طفل وزيبوى ، نو طفـل نمايد ، جنين طفل منسوب به زوج

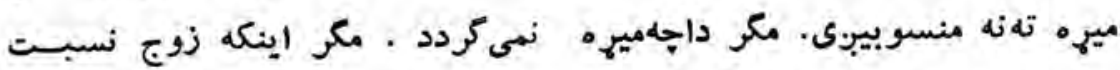

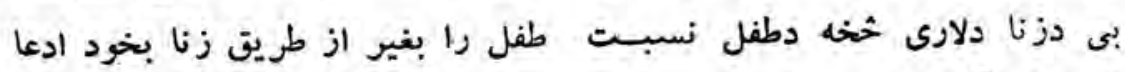
نمايد

جزء دوم - ثيوت نسب بعد از

تفريق ياوفات ذوج

- r. Plo خان ته وكى دولى

دوهم جزء - دجدائى او دميسيه دمرك وروسته ، دنسب ثبو ت

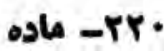

هر كاه معتده طلاق ياوفات د ر ماده هدت بيشتر ازيكسال ازطلاقياوفات زوج وضع حمل نمايد ، دعوىنسب جنين معتده قابل سمع نمى باشد . مكر اينكه در صورت طلاق زوج ودز وفات ، ورثه زوج نسبت طقل ر 1 بخود ادعا نمايد ، ولهات - FrI كه دطلاق يا وفات معتده دميـه دطلاق يا وفات خخه وروسته ديوه وفات مات ومتهات

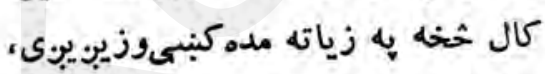

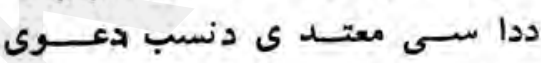

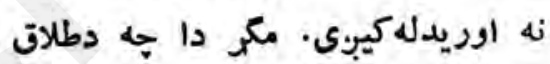
يه صورت كبنى يخيله ميره اودوفات

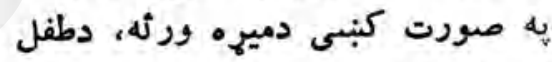
نسبت خبل خان ته وكى .

ماده

هر كاه مطلقه يازوجه بعد ازوفات

كى طلاقه شوى يا بنتخه دخيـــل زوج به تكميل عدت خود اقرارنمايد، نسبت طفل او ,ه زوج وقتى كابت مى مردد كه وضع حمل در مدتكمت از ششماه از اقرار وياكتراز يك سال از طلاق ياو فات زوج، صورت كرفته باشد .

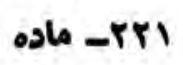

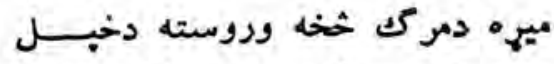

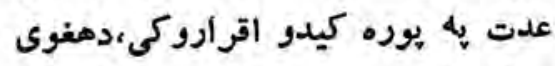

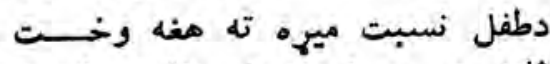

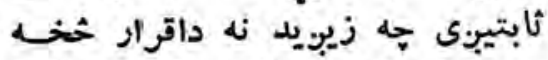

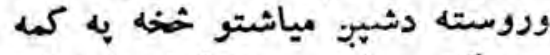

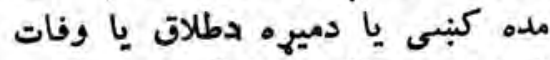

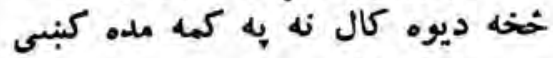
صورت موندلى وى دول نه 
جـزءء ســـو م - ثبسو ت نسب در

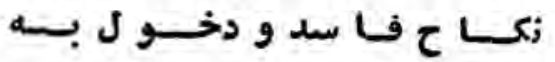
شببهـ - rrr
دريم جزء - يه فاسبه نكاح كبنى او دشبهى يه دخول كنبسى دنسب ثبوت ryr

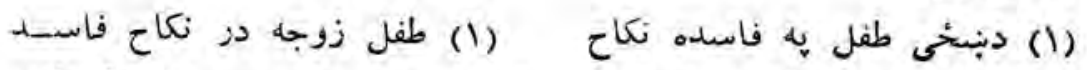

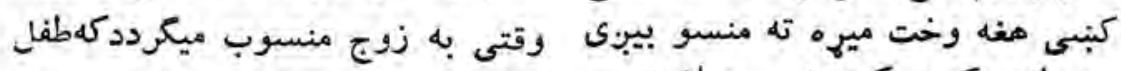

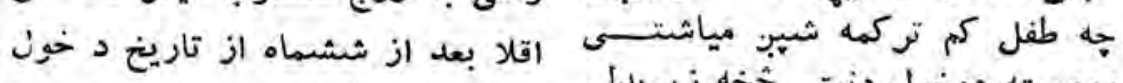

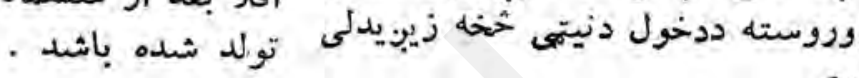

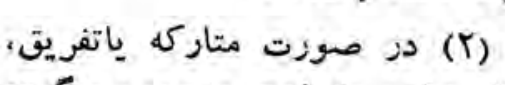

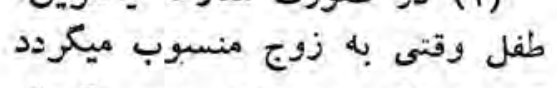

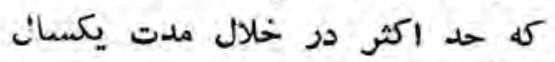
تولد شده باشد اكثر - rrr

درصورت ثُبوت نسب كرهيه درة

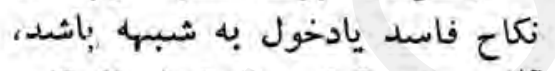

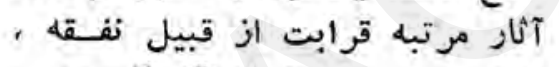

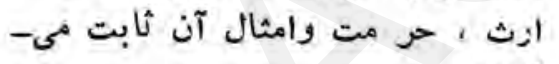

$$
\text { كرد }
$$

$$
\begin{aligned}
& \text { جزء حارم - اقراد بهنسب } \\
& \text { ماده }
\end{aligned}
$$

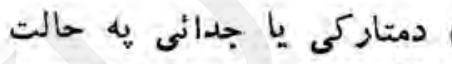

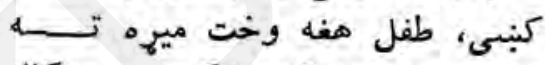

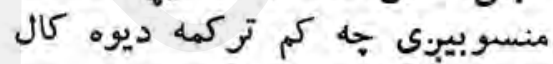

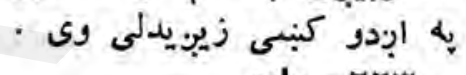
ماده

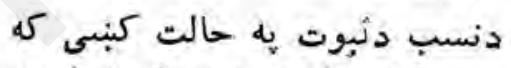

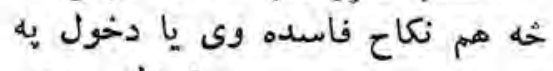

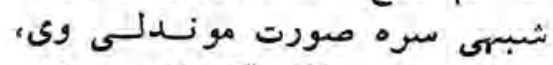
دخيلوى هرتب آثنار لكه نفقه، مير اث،

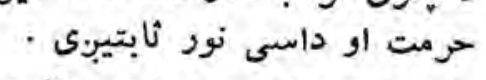
خلودم جزء - ـ هيه نسب اقراد عادم - YrE

ثبوت نسب توسط اقرار بهبنوت

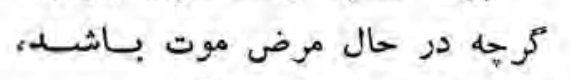

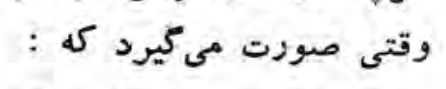

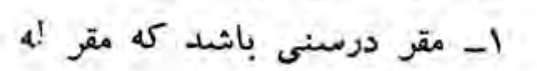
فرزند وى ثشده يتواند .

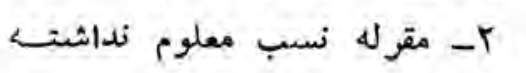
باثد يها نسب ثبوت ماده دزوى ولى داقرار

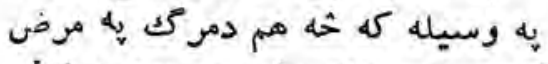

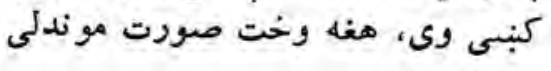
شى جه :

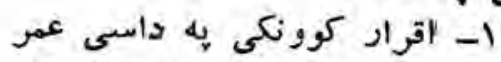

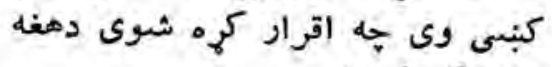

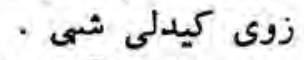

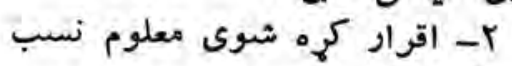
ونه لرى . 
بــ مقرله مهيز اد عاى مــــر را تصديق نمايد مقاد ماده

ماده - rro

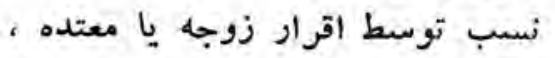
وقتى ثابت ميكردد كه زوج اقسرار زوجه را تصديق و ياازطرف زو زو جه

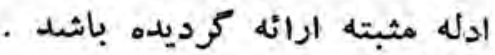

\section{-}

شخصيكه نسب وى معلوم ثباشند

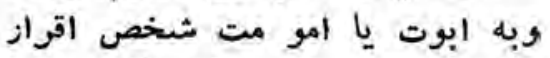

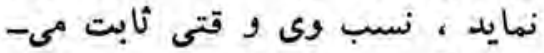

ا- مقر دزسنى باشد كه فر فرزند

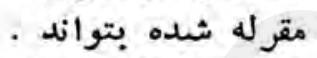

r- مقرله ادعاى مقر را تصديـت نمايد . ن

درينصورت حقوق ابوت وبنوت دزبرابر يكديكر ثابت ميكردد.

\section{- rFV ماده}

اقراز به نسب در خارج ازبنوت،

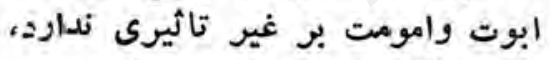

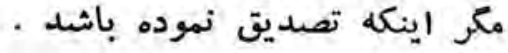

\section{- ماده}

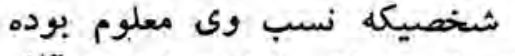

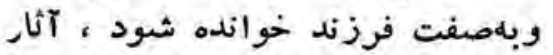

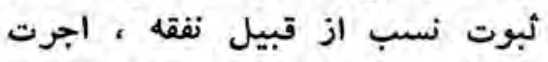
حضانت ، ميراث ، ، حرمت مصاهره

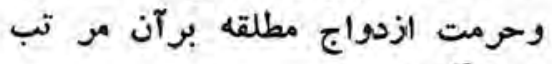

r- مهيز اقرار كيجه شوى داقر ار كوونكى دعوى تصديق اكى ماتى 0 ק r - ماده دنسب اقرار دبنسخى يا معتدى يها يه

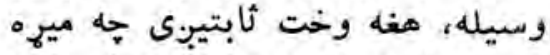

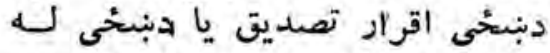

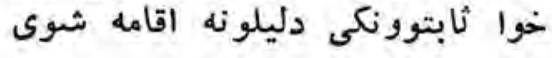
وى

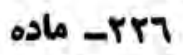

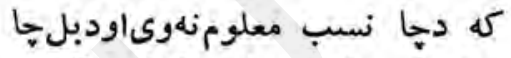

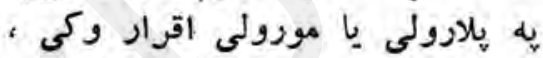

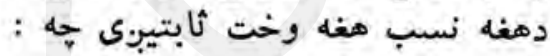

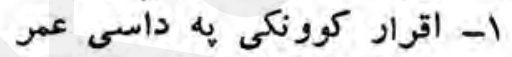

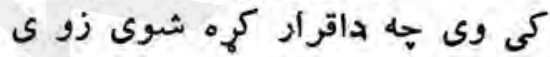
كيدلى شى وي

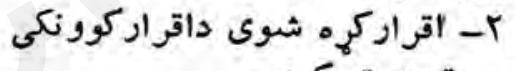

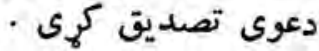

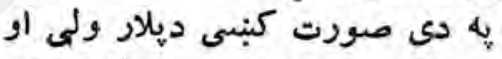

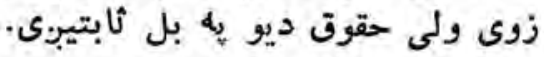

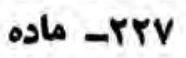
يه نسب اقرار دزوى ولى، يلارولى

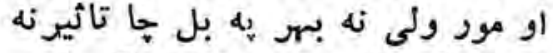

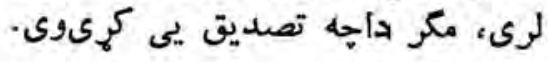
Arr

كه دهانسب معلوم ماده وى اودزوى بها

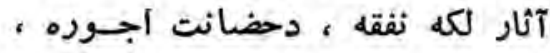
مير اث ، دمصاهرت حرمت اودطلاقى شوى بنّخى حرمت ميرىثله مرتبيبيى. 


$$
\begin{aligned}
& \text { فرع دوم - دضاع } \\
& \text { ماده }
\end{aligned}
$$

$$
\begin{aligned}
& \text { ووهمه فرعه - رضاع } \\
& \text { צra }
\end{aligned}
$$

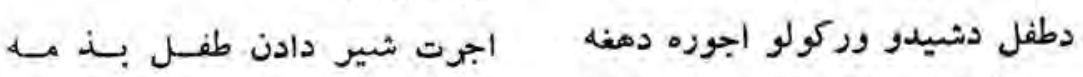

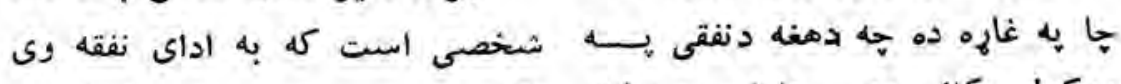

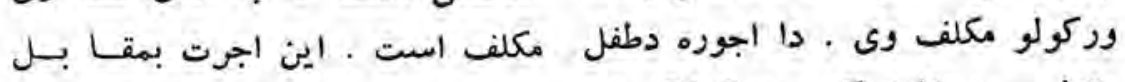

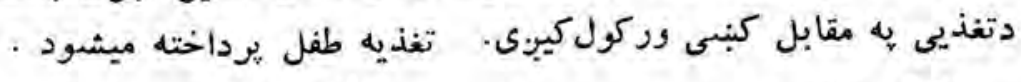

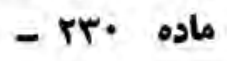

$$
\text { osto }
$$

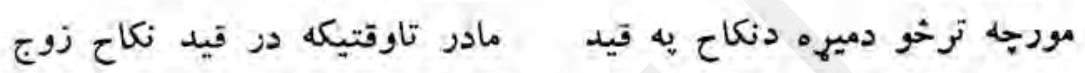

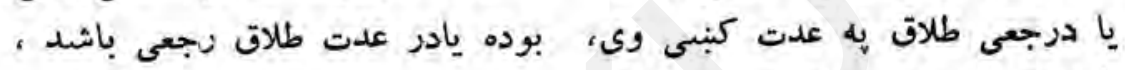

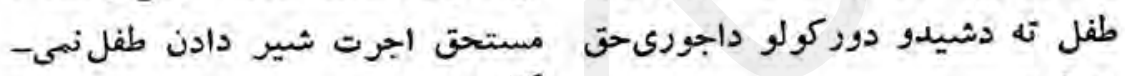
كردد ماد

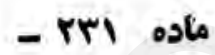

$$
\text { نه لهى - آله }
$$

هر كاه مادر طفلش وا درخلالعدت

كه مور خيل طفل ته دبائسنطلاق طلاق بائن يابعد از تكميل آن شير طادير

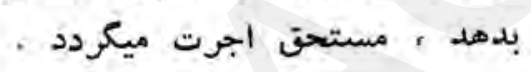

- rur to

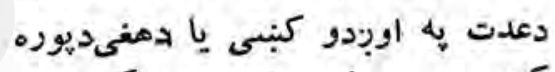

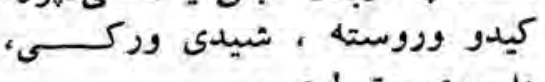

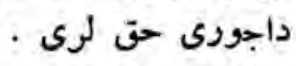

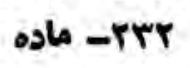

مادر بيش از دو سال ، مستتحق

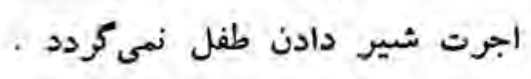

$$
\text { - ماده }
$$

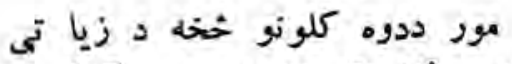

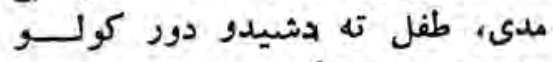
داجودى حقى طنه لرى مانه rrr

هركاه زن ديكرى بدون اجرت يا به اجرت كمتر از آنجه مادر مطالبه

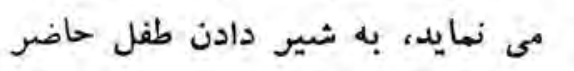
شود ، مادر مستحق اجرتشيردادن

$$
\text { نمىكردد . نمود مادر }
$$

كه بله بتخهن بى له أجورى يــا دهغى اجورى خخخه جه دطفل مور يیى

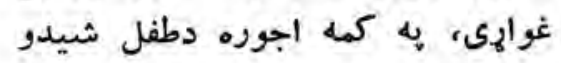

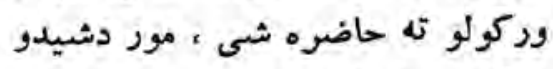
وركولو حق زه لوى حاضره 


\section{اجرتيكه نسبت شير دادن برا عي}

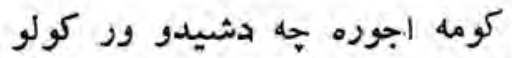

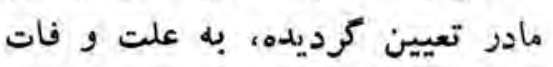

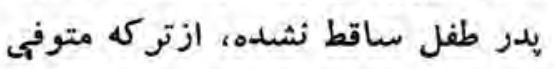

مثل سايو ديون لير داخته ميشود

ماده - rro اله امله مورته تاكل اجثورى، دطفله ديلار

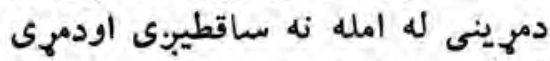

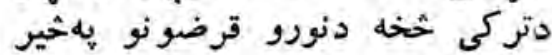

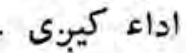

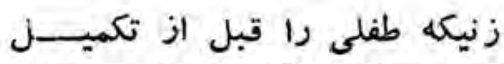
O مدت دوسال از تولدوى شير قدير بدهد، مادر رضاعى طفل و ثختصيكه بــه سبب مقاربت او شير بو جود رود آمده باشد، يدر رضاعى وىمحسوبشده،

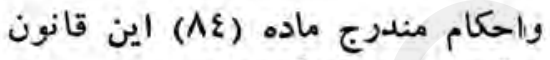

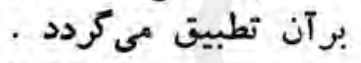

$$
\begin{aligned}
& \text { فرع سوم - حضانت } \\
& \text { ماده }
\end{aligned}
$$

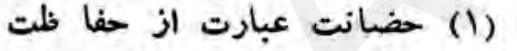
ويرورش طفل است در مدتيكه طفل به حفاظت ويزورش زيل زن محتاجباشد. (T) حضانت حق الشخا كه به اساساين قانون تنظيمكرديده

\section{- RrV}

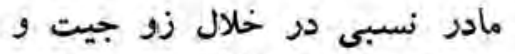

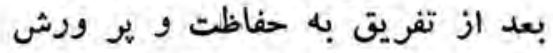

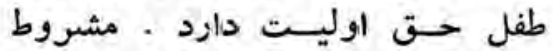
بر اينكه واجد شر ايط اهليت حضانت

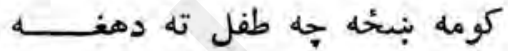

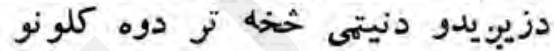

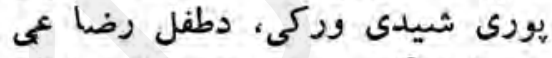

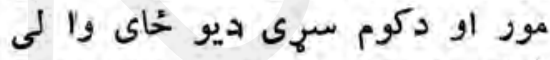

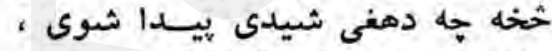

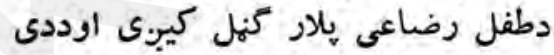

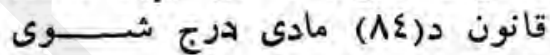
حكمونه ور باندى تطبيق دريمه فرعه - حضانت وري تطبين

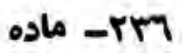

(1) حضانت دطفل دساتنى او (1)

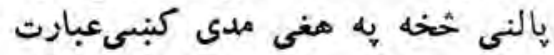

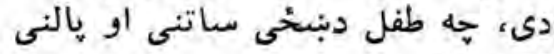

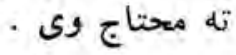

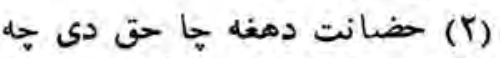
ددى قانون يه اساس تنظيمشوى دئ. ن إد

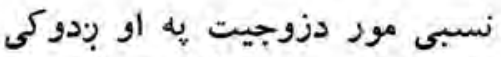

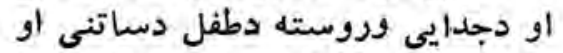

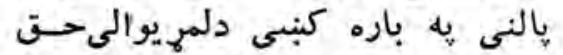

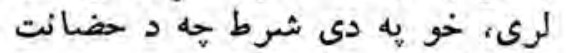
دشرطونو لرونكى له دي شعرط 


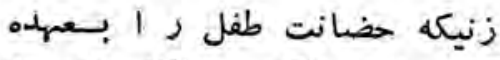

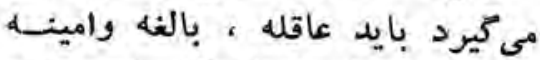

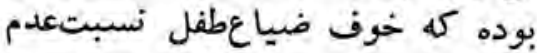

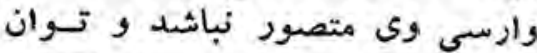

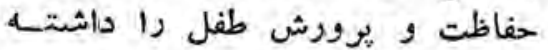

\section{ماده}

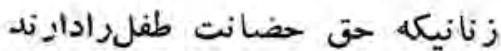
بترتيب درجه ا ستحقات عبارت اندان سفراند

1- مادر، مادر مادر ويا بـالاتر ازآن .

$$
\begin{aligned}
& \text { r- مادر يدر . }
\end{aligned}
$$

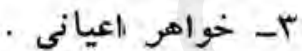

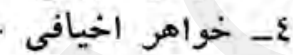

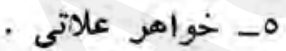

$$
\begin{aligned}
& \text { 7-7 دختر خوا هر اعيانى" }
\end{aligned}
$$

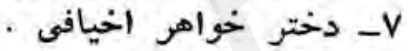

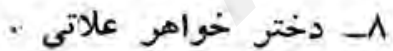

$$
\begin{aligned}
& \text { - ج- خاله اعيانى } \\
& \text { · 1. } \\
& \text { · }
\end{aligned}
$$

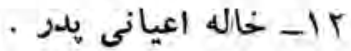

$$
\begin{aligned}
& \text { rا }
\end{aligned}
$$

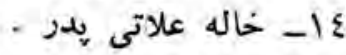

$$
\begin{aligned}
& \text { - }
\end{aligned}
$$

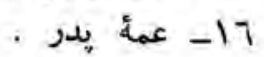

كومه بندخه جه دطفل مضاده حضانت يه

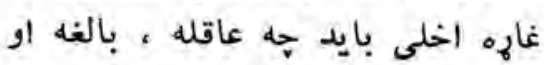

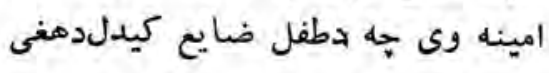

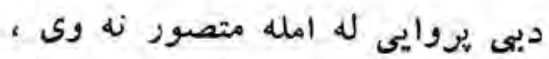

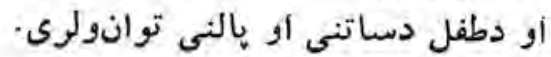

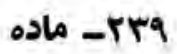

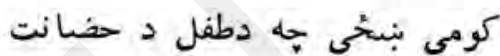

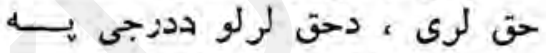

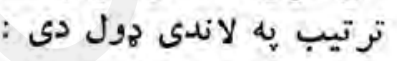

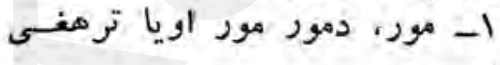
يورته .

$$
\begin{aligned}
& \text { ب- دونالار مور . } \\
& \text { - ع- اعيانى خور مور } \\
& \text { ع- اخيافى خور . }
\end{aligned}
$$

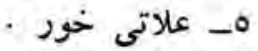

$$
\begin{aligned}
& \text { 7- 1اعيانى خورلور } \\
& \text { V-اخيافى خور لور. }
\end{aligned}
$$

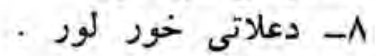

$$
\begin{aligned}
& \text { 9- اعيانى ترعاتى تخور }
\end{aligned}
$$

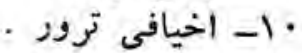

$$
\begin{aligned}
& \text { الا }
\end{aligned}
$$

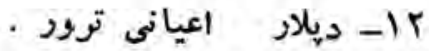

$$
\begin{aligned}
& \text { ك }
\end{aligned}
$$

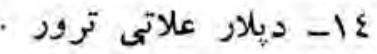

$$
\begin{aligned}
& \text { 10- دمور عمله } \\
& \text {. } 17
\end{aligned}
$$




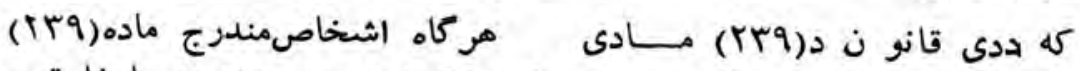

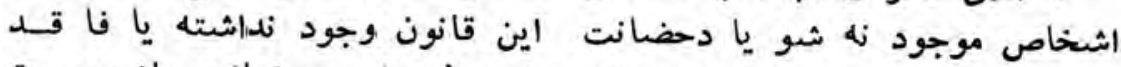

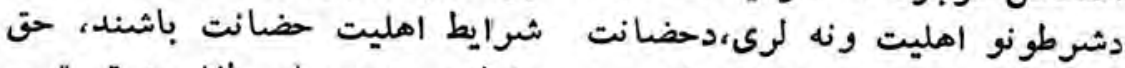

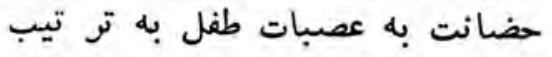

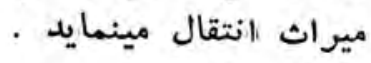

\section{ماده}

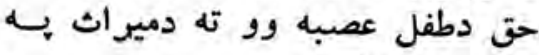

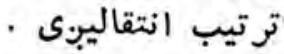

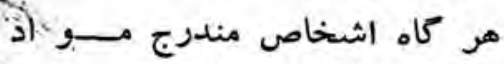

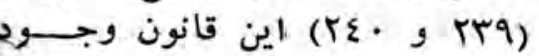
نداشته يافاقد شرايط اهليتحضانت باشند ، طفل جهت حفاظت يروير به نزديكترين محرم از ذوى ذالارحان

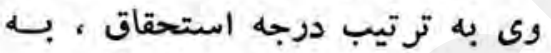

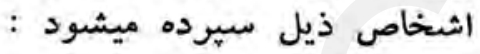

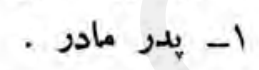

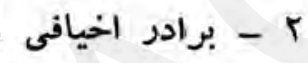

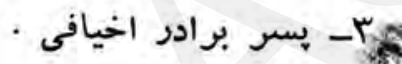

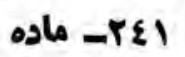

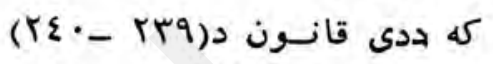

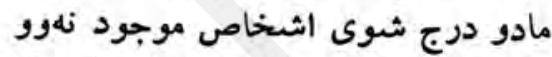

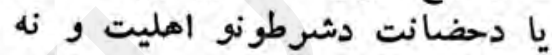
لوى نو طفل دساتنى او يالنى دياره

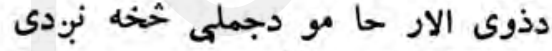

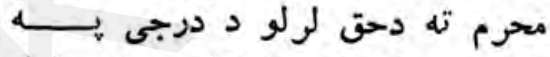
ترتيب ، لاندنيو اشخاصو تهني لهيارل

$$
\begin{aligned}
& \text { كيب.ى تر تيب } \\
& \text { - 1- دمور : عيلار }
\end{aligned}
$$

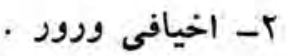

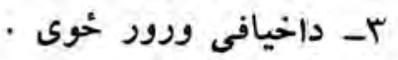

$$
\begin{aligned}
& \text { ع- اخيافى تره }
\end{aligned}
$$

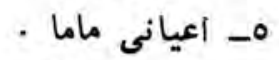

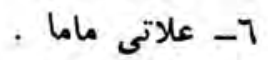

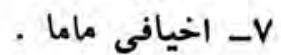

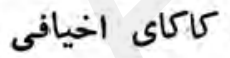

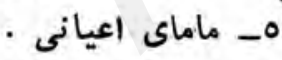$$
\text { - 7 - ماماى علاتى }
$$$$
\text { · }
$$

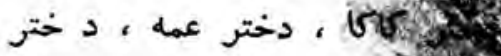

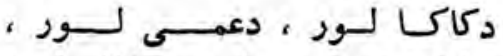

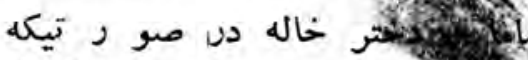

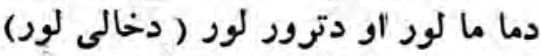
?

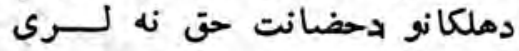

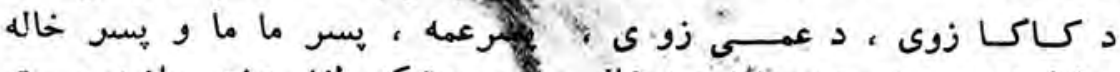

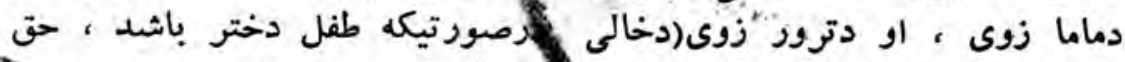

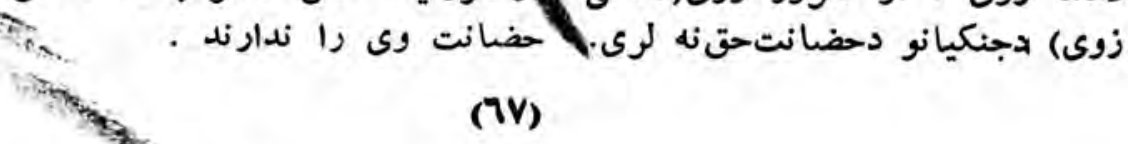




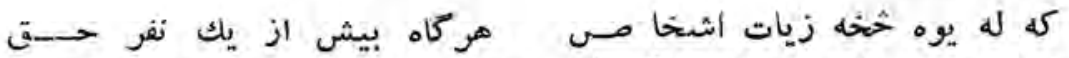

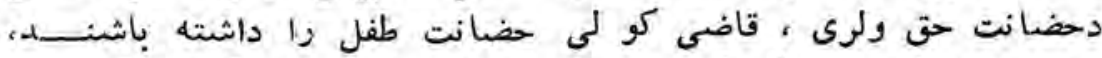

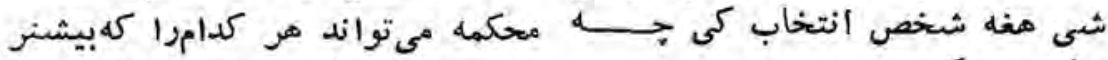
به مصلحت طفل باشد، انل صرام انتخابنمايد.

\section{ماده}

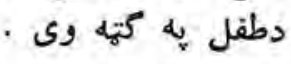
ole rer

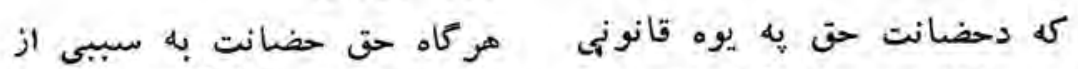

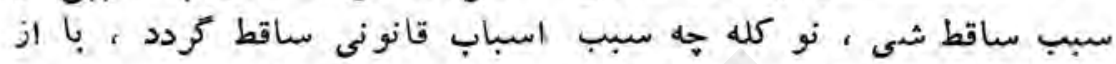

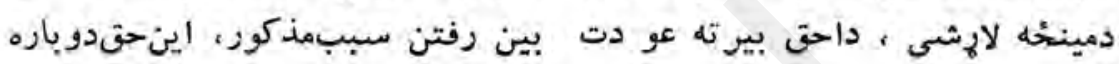
- اعاده ميكر رفن

\section{ماده} كوى ع

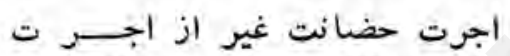

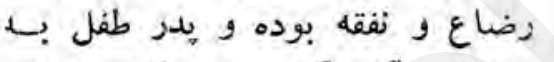

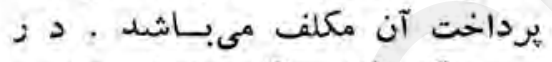

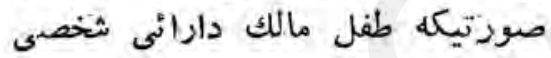

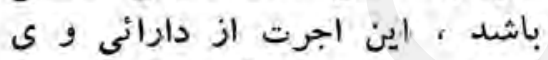

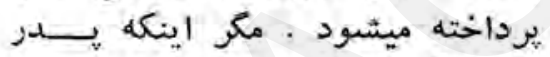

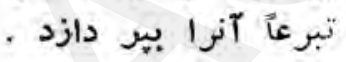

$$
\begin{aligned}
& \text { ماده }
\end{aligned}
$$

دحضانت اجوره به يلار لازمه ده

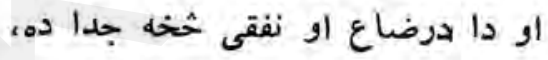

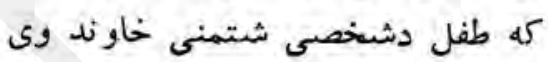

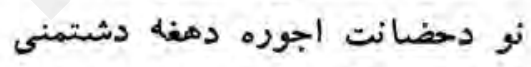

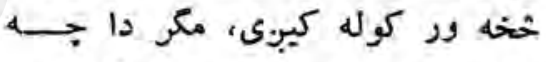

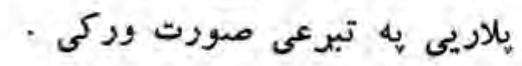

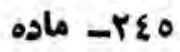
(1) مادز تاوقتيكه در قيد ناده (1)

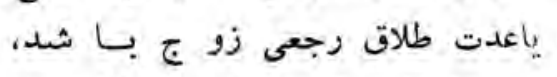

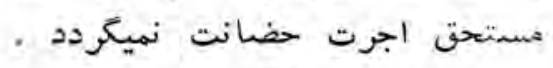
ره

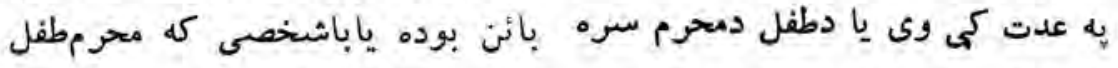

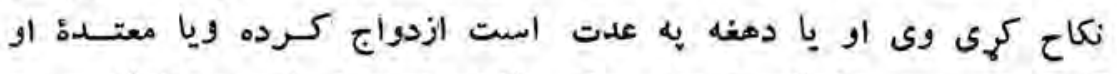

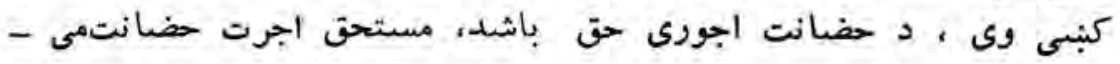
. 


\section{- rEY os}

هركاه شخص مكلف بـه يرداخت اجرت حضانت، معسر بوده و يكىاز محارم حضانت طفل را تبرعاً بعهده

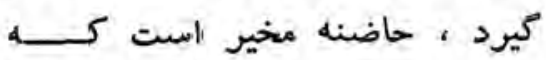
حضانت رابدون أجرتبعهده كرفته ويا او را به متبرع واكذار شود .

\section{ماده}

هركاه شخصص مكلف بير داه حان حت اجرت حضانت، موسربوده وطفل ئليز

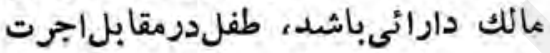

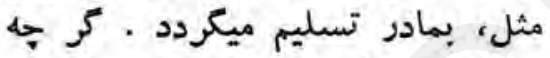
اين اجرت از دارائى صغير برداخته ميكرد . برديه

\section{- TEA ماد}

هر كاه زوجه ناشزه كردد و سن المن

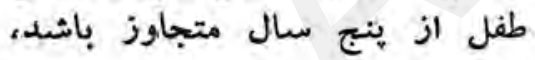

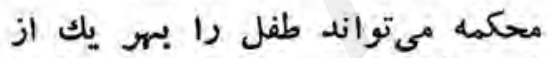

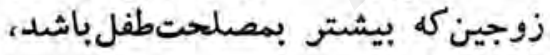

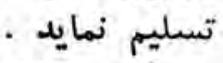

$$
\text { - rEq ماده نماند }
$$

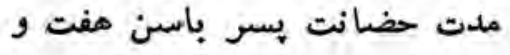
ازدختو باسن (9) سالكى تمامخاتهه

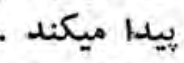

$$
\text { - ro. }
$$

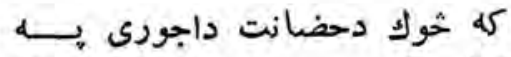

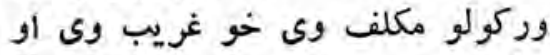

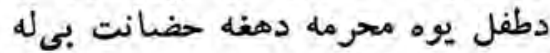

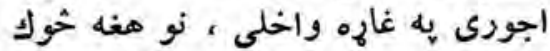

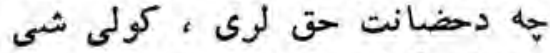

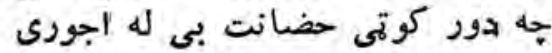

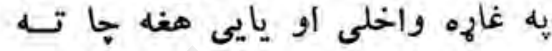

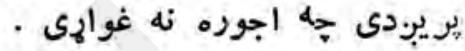

$$
\text { كاد }
$$

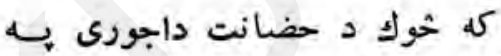

وركولو مكلف وى او شتمن وى او او

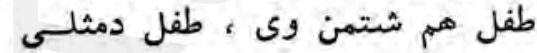
اجورى خه مقابل كنبسى مورته سبارل

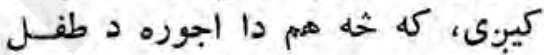

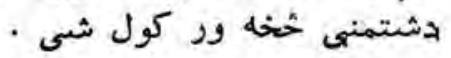
A

كه بندخه ناشزه شيى او دطفل ماده

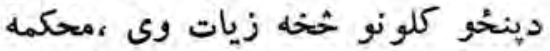

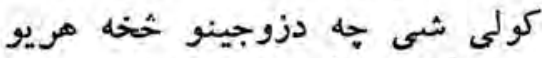

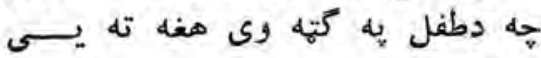

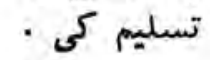
\& 9 \& دهلك دحضانتملده يوره اووه كاله

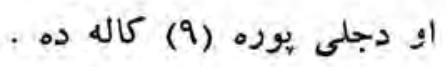$$
\text { • ro- ماده }
$$

محكمه كولىشى ماده د دى قانو ن

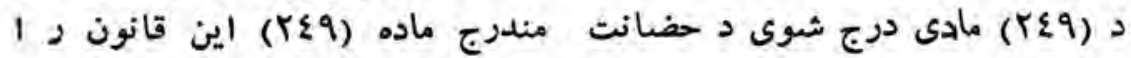


تهديد نهايد. مشروط براينكه مدت مديد شبده از دوسال تجاون تماوز نكند.

$$
\text { - rol }
$$

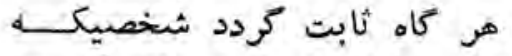

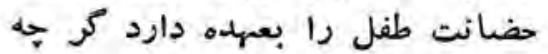

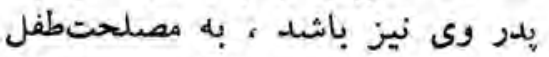

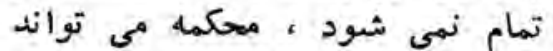

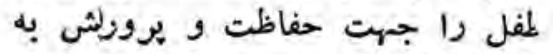

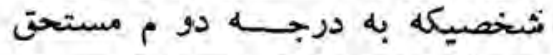

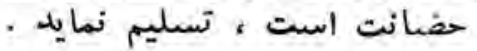

$$
\text { - ror oslo }
$$

مادر تا وقتيكه در قيد نكاح يــا عدت باشد ، نمى تواند بدون اجازه ونيد

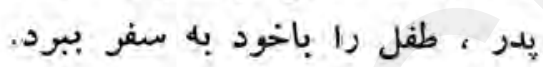

$$
\text { - ror or }
$$

حاضنه غير از مادر نمى توازنـد بدون اجازه ولى ، طفل را با خــود

$$
\begin{aligned}
& \text { به سفر ببرد . ماره } \\
& \text { - ماده }
\end{aligned}
$$

يدر طفل نمى تواند در خلالمدات

حضانت بدون ابازه حاضنه، طفلرا لندرا

$$
\text { باخود به سفر بيرد . ماده }
$$

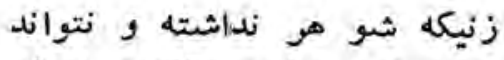

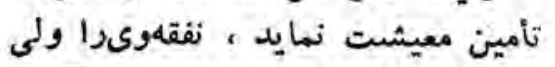

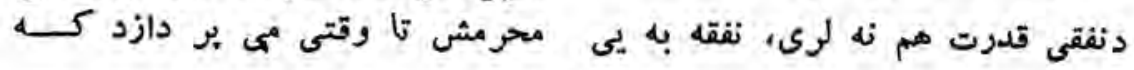

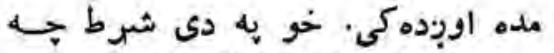

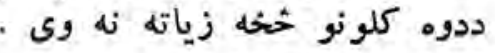
مادم rol

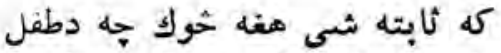

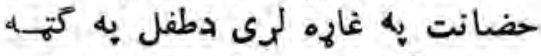

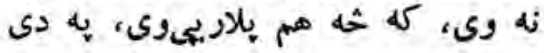

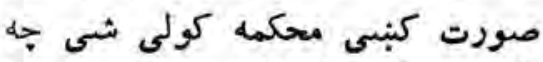

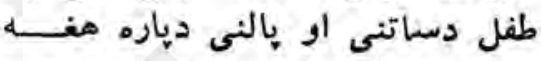

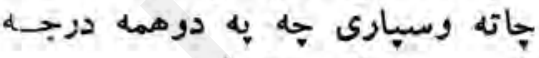

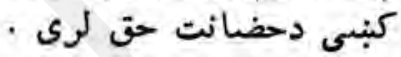

$$
\text { ه ror }
$$

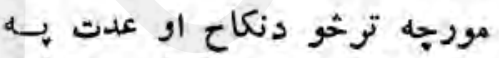

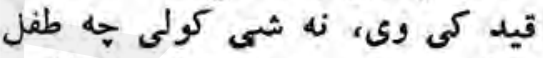
دخان سره بلى دمغه ديلار دأجازي

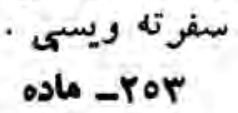

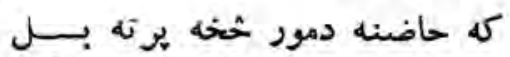

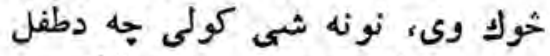
دولى داجازى يه غير هغه دخانه سفرته ويسي داري نهاري ـ roz

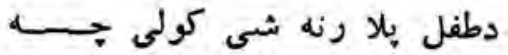

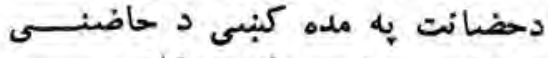

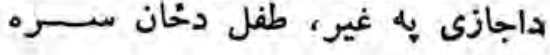
سفرته ويسى · هاجئ O roo كومه بنخه جه ميهه نه لرى او 
محرم ولى ترمغى وركوى جهدمحرم مشاراليها درمسكنولميمحرم مذكور

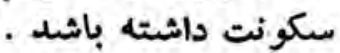

$$
\text { فرع جهارم - انفاق }
$$

جزء اول - نفقه اولاد - مادم

$$
\text { - ror مادم }
$$

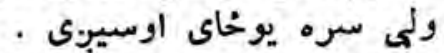

خلورمه فرعه - دنفقى وركول

لهمى جزء - داولاد نفقه

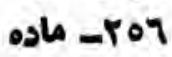

نفقه باتمام انواع آن در قسمت

يسر صغير تاوقت توان كسب وكار

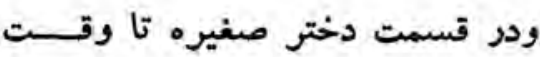

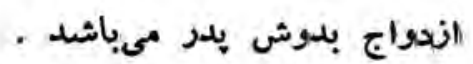

- rov ماده

نفقه يسر كبير كه توان كسبو

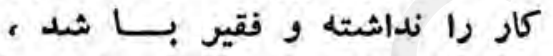

همجنان نفقه دختر كبيره فقيره تأن

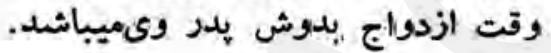

- ron os

(1) مصارف نفقه يسر يا د ختر

صاحب كسب و كار درصورت كفايت

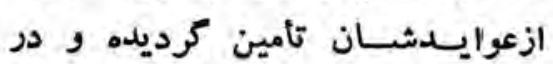
صورت عدم كفايت بقيه نفقهازطرف كرديد وديد يدر تكميل ميكردد .

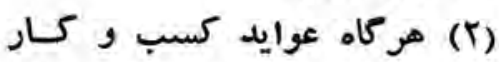

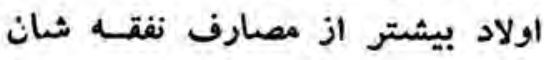

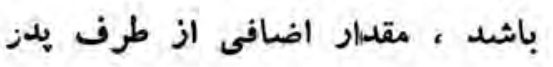

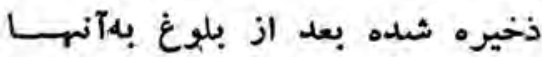

نفقه دتولو انواعو سره دصاه دصغيسر

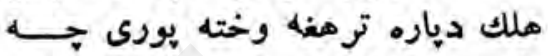

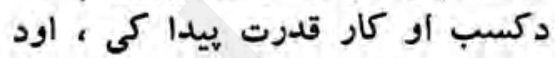

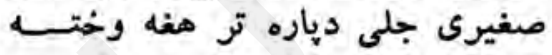

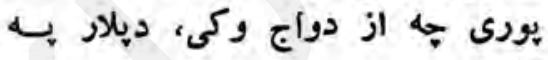

$$
\text { ماده - rov }
$$

دبالغ زوى نفقه جه دمسب اوك اوكار

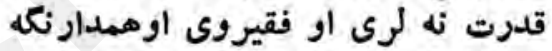

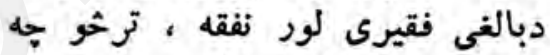

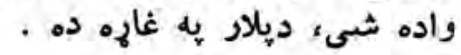

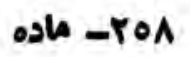

(1) (1) (1) دملك يا جلى دنفقى مصرف

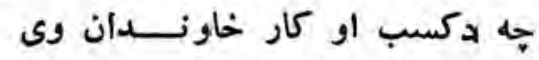
دهغوى دعايداتو خخه تا مينيبى او

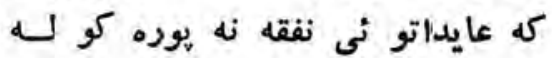

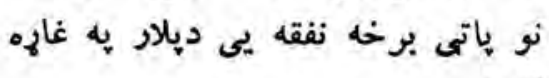
(r)

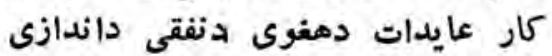
ثخه زيات وى ، زياته برخه عايدات

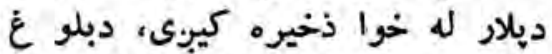
خخه وروستههغوى ته وركول 


\section{- ro9 ماده}

هر كاه يدر توان ير داخت نفقده اولاد خود را نداشته واز كسبوركأ نيز عاجز باشد ، مكلفيت نفقه اولاد ولداد وادئ

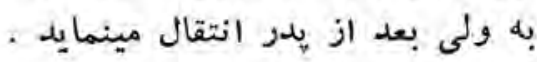

\section{- ry.}

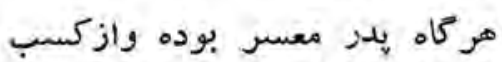

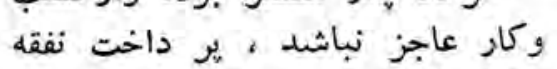

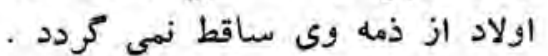

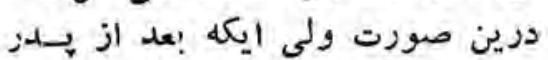

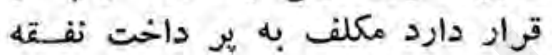

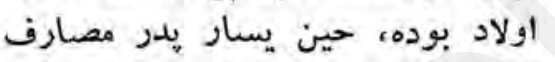

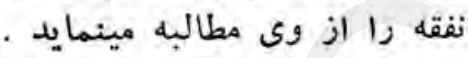

$$
\text { ماده }
$$

طفليكه يدرش وجود نداشته ماده مالكدارائى مشخصى نباشد وند درد نداليكه

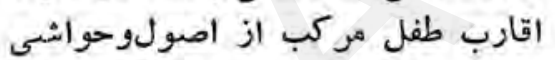

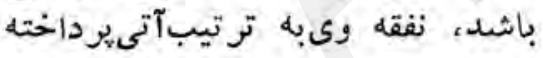

$$
\text { مى شود : بانشئ }
$$

1- در صورتيكه تثنها اصول ويا

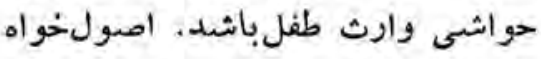

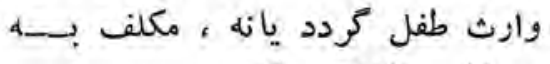

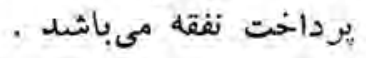

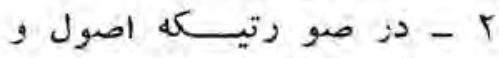
حواشى مشتركاً وارث طفل باشند. نفقه به تناسب سهم ميراثهر كدام وارث

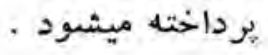

roq كه يلار خيلاولاد ته دنفقىوركولو ماده

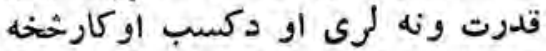

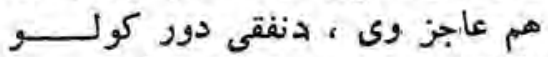

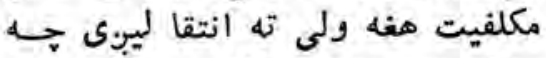

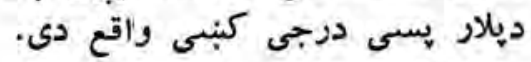
• .

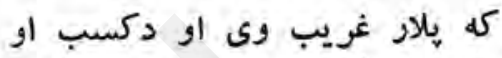
كار قدرت ولرى ، دأولادي وند اونفقى دوركول

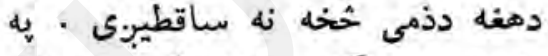

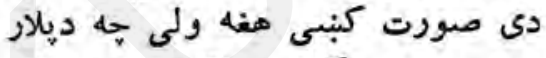

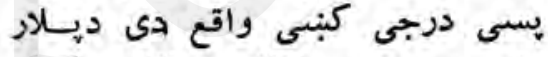

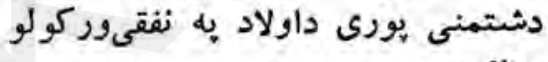
هلف دى . دئف

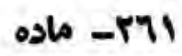
كومطفلجه يلارنه لوى لواودشخصى ماده

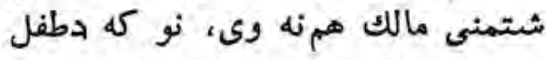

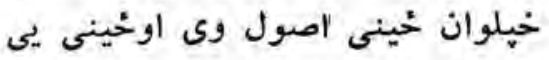

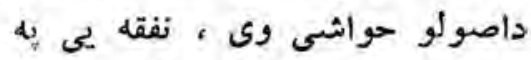
راتلونكى ترتيب وركول كيب.ى :

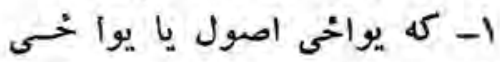
حواشى وارثان وى ، دطفل نفقه به اصه

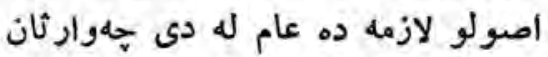

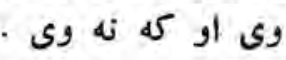

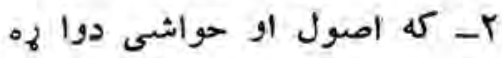
وارثان وى ، دطفل دنفقى ور كول

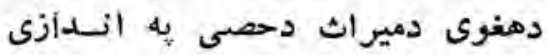
لازميبيى دمعزي 


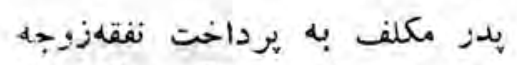

بسم ش نمى !اشد ، مكر اينكه قبلا

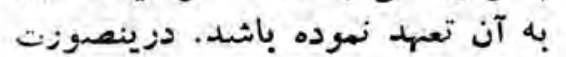

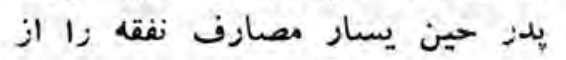

وى مطالبه مينمايد .

\section{- rar}

زوجين مىتواننددر مورد مصازف

نفقة اولاد شان صلح نمايند . هر كاه

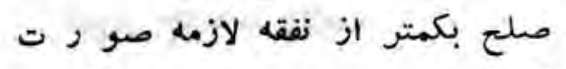
كرفته باشد ، بدز مكلف بكتر از به لازمه تكميل

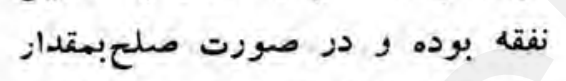

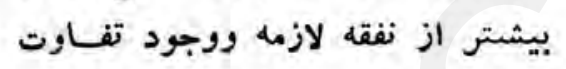

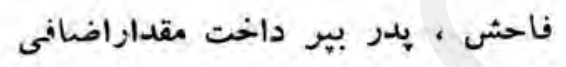

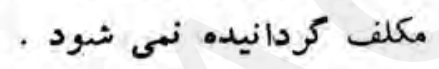

جزء دوم - نفقه ابا واقارب

- ناده

ففقه والدين ، اجداد و و حداتيكه

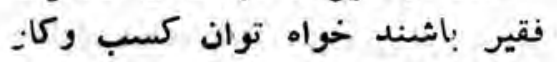

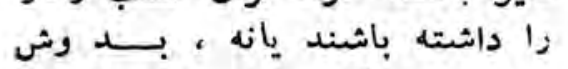

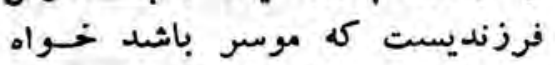

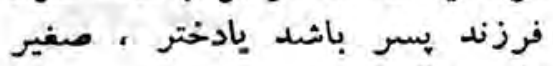
باشد ياكبير باند

\section{- ryo ماده}

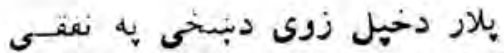

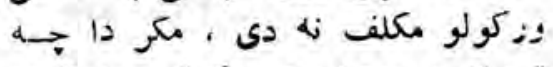

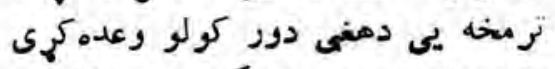

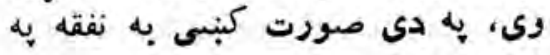

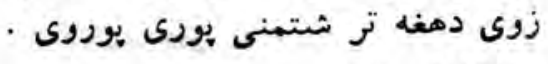

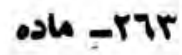

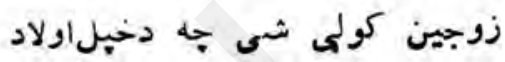

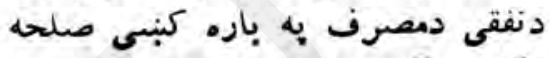

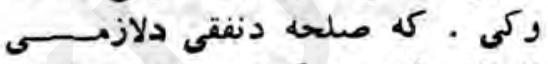

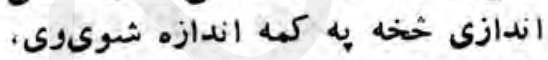

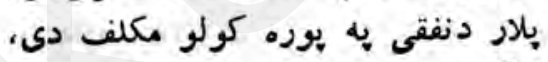

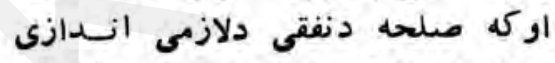

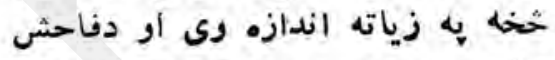

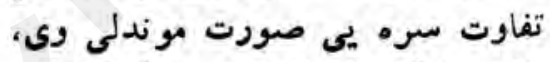

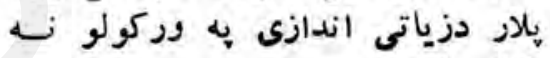
مكلف كيبي.

دوهمجزء - ديلرونواو خيلوانو نفقه ع عr- ماده

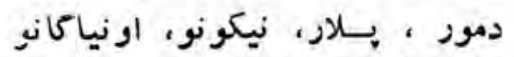
نفقه كه دكسب قدرت ولرى اوكهيى اوني ونه لوى خو جه فقير وى دهغ دون اولاد

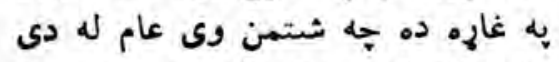

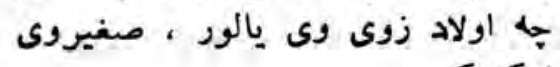
اوك كبير اولاد زوب ماد

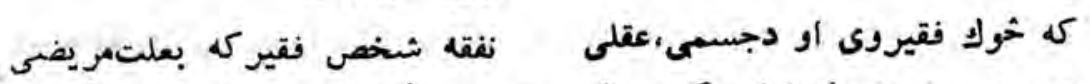

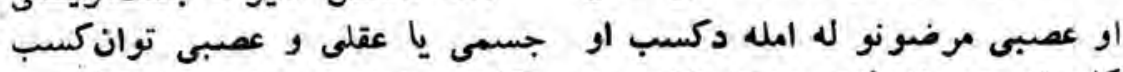

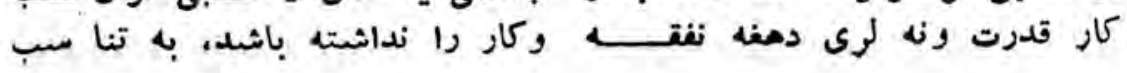


سبهم ارث بدوش اتارب موسر مي-

$$
\text { ماده }
$$

، ماستشناى نفقه اصول و فرو

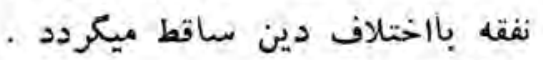

$$
\text { osh -ruv }
$$

لفقه اقازب از ثازيخ مطا لبه آن ماده

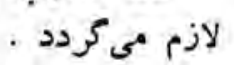

$$
\begin{aligned}
& \text { فرع هنجم - اداره اموال } \\
& \text { جزء اول - ولايت } \\
& \text { ماده }
\end{aligned}
$$

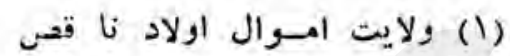

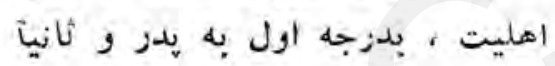

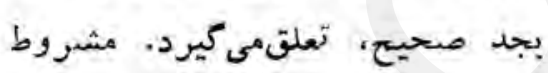

براينكه از طرف بيدر وصى تعلى تعبيسن

$$
\text { نكرديده باشد ازنه }
$$

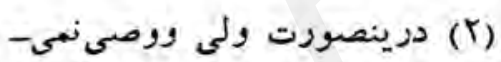

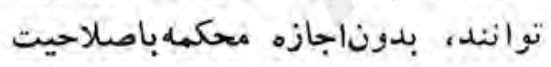

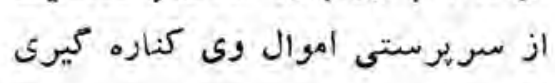

$$
\text { نمايند }
$$

\section{- Fla}

ولى وقتى مى تواند از حسقو ق متعلق بولايت استفاده نمايدكةواجد اهليت كامل در مورد استفادهازعين

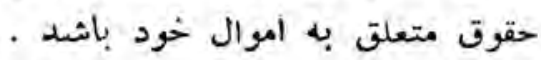

دميراث دحصى يه تناسب دثتهنــو

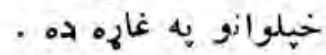
דרז- ماده

داصولو او فروعو دنفقى خخه يه ميه غير ، نفقه ددينيه اختلافساقطيب.ى فرون - riv دخبلوانو نفقه دمغوى د غو بنتنى

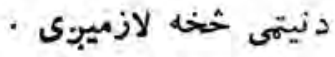

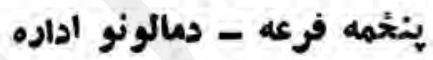

$$
\begin{aligned}
& \text { لميى جزء - ولايت } \\
& \text { גרז- ماده }
\end{aligned}
$$

(1) (1)

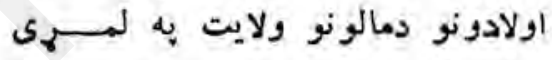
درجه كبنى ديلار بيا دصحيت نيكه دى · خو بيه دىشبرط جهديلازله خوا

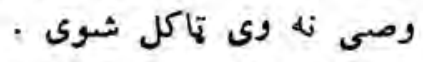
(r) ولى او وصى نه شى كو لهى جه بى د صلاحيت لرونكى محكبى له اجازى دمغه دمال ديالنى او ماتنى

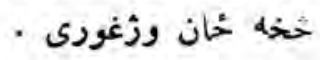

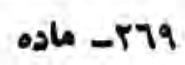

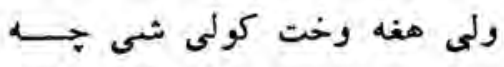

دولايت بورى دمربوطو حقوقو خخه

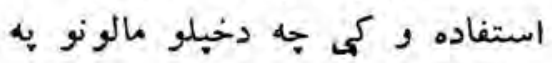
بار• كبنى دعين حقوقو داستفادى كولو بوره اهليت ولرى دعين حتوقو 


\section{- rV. ماده}

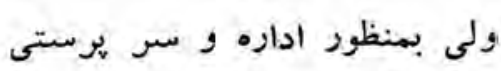
تواند مطابق با حكام مندر جالم ايسن

$$
\text { قانون تصرف نمايد . }
$$

\section{ماده rVI}

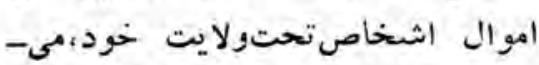

( J

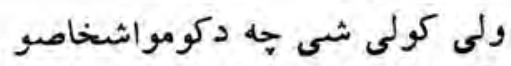

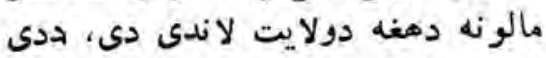

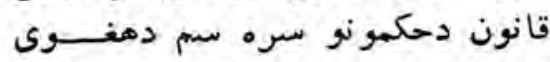

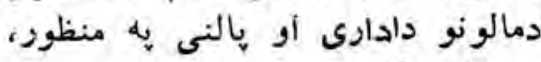

$$
\text { تصرف وكى دونى }
$$

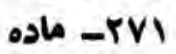

هر كاه باشخاص ناقص 1 هليـت

كه داهليت ناقصو اشخاصو تـهـ

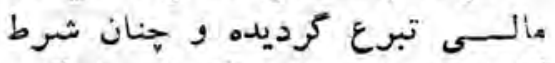

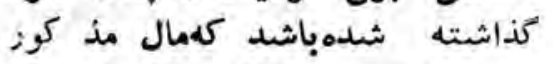

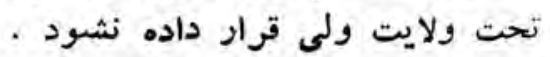

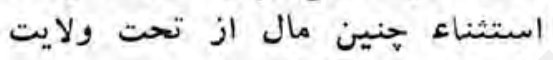
ولى خارج ساخته ميثود مال مارد

\section{- rVr}

ولى نمى ثواند اموال اشتحناص تحتولايت خودرا بدوناجازه محكمه نواند

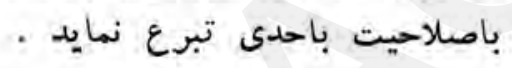

$$
\text { - rvi }
$$

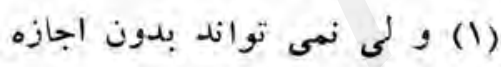

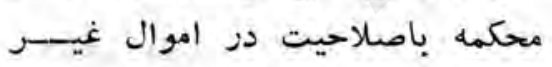

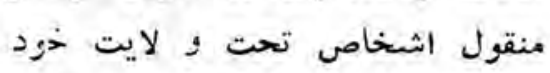

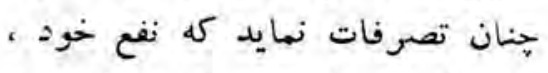

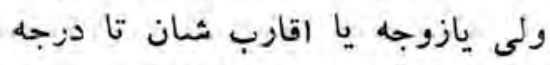

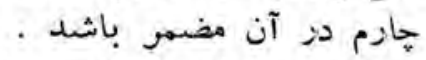

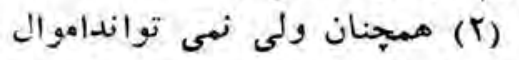

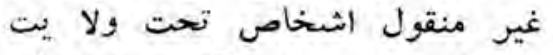

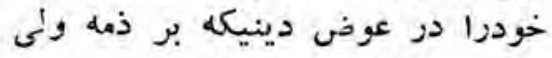
باشد برهن :عذارد . برون

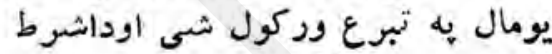

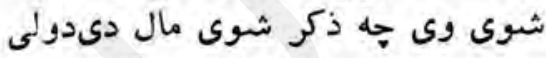

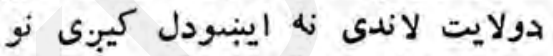

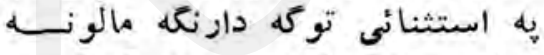

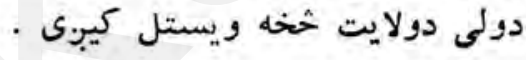

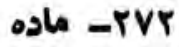

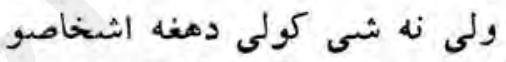

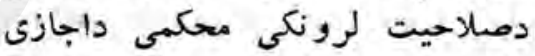

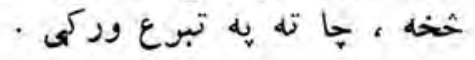
r r r

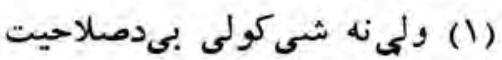

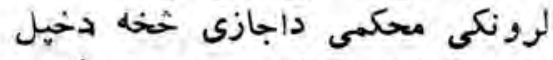

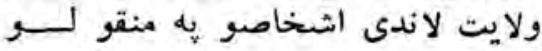

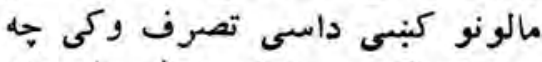

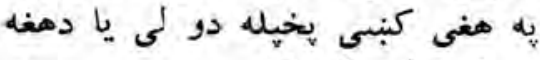

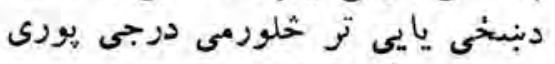

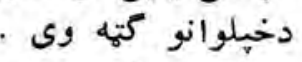

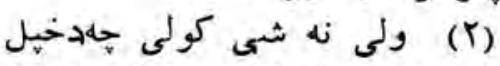
ولايت لاندى اشخاصو عقار دهئه

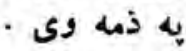

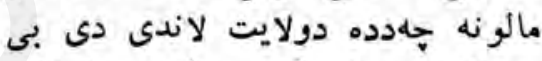

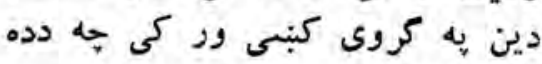


- TVE

يدزنهي تواند بدون اجازه محكمان

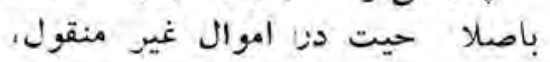

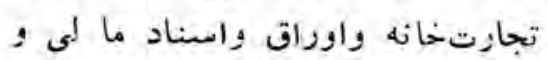
بهاداز اشخاص تحت ولايت خوديه

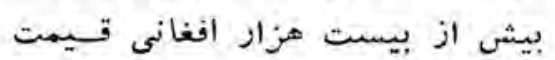

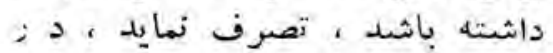

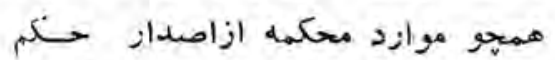

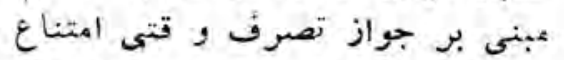

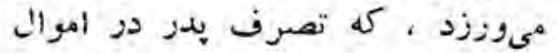

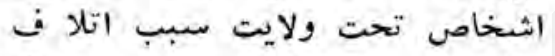

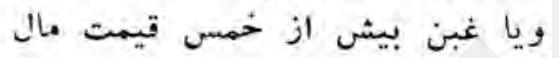

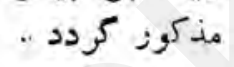

\section{- rvo}

هركاه مورث شخص ناقص امليت

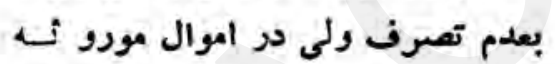

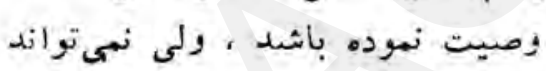
بدوناجازه ورنظارت بحكمه باصلاحيت

$$
\begin{aligned}
& \text { در آن تصرف نهايد . } \\
& \text { - rvi alo }
\end{aligned}
$$

ولى ثمى ثواند دز اموال اشتخاص تحت ولايت خود بدون اجازه محكمه لونه

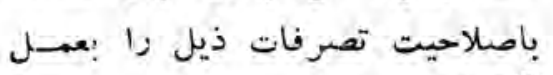
آر

$$
\text { 1- قرض دادن ياقرض كرفنن. }
$$

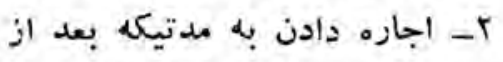

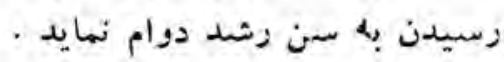

$$
\text { ماد rvE }
$$

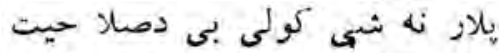

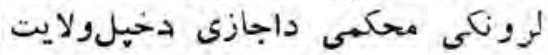

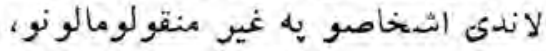

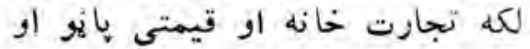

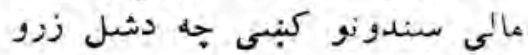

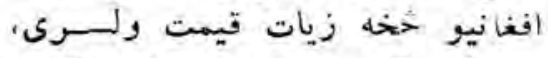
تصرف وكىى به داسيى موازيه دودو كبنى

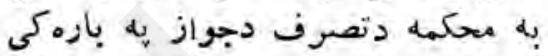

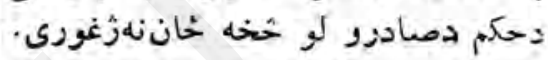

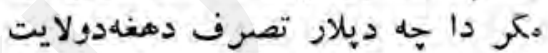

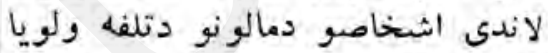

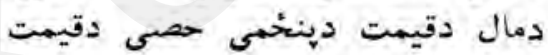

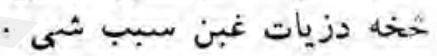

$$
\text { rvo }
$$

كه داهليت نقصان لرونكي ماده

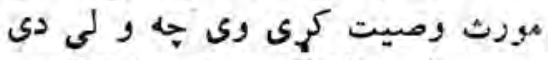

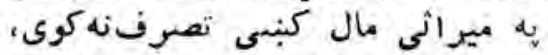

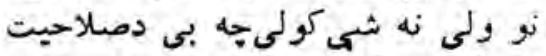

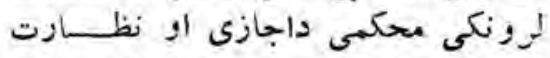

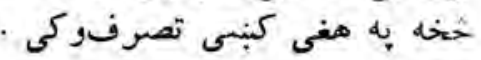

$$
\text { ר }
$$

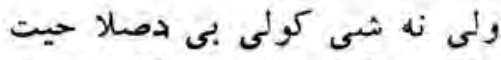

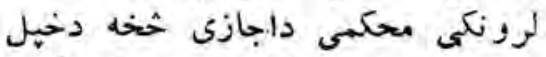

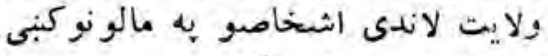

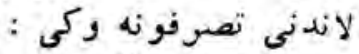

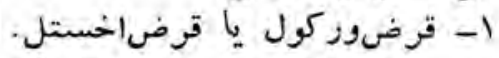

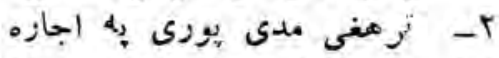

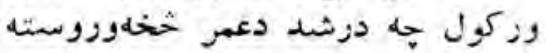
- 
$\alpha$

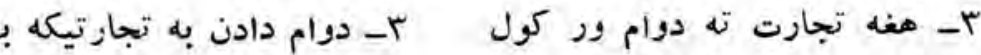

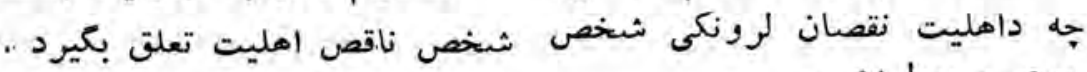

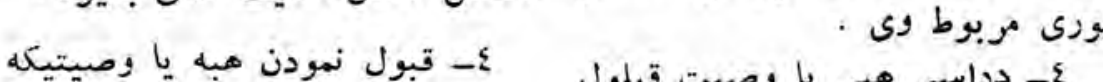

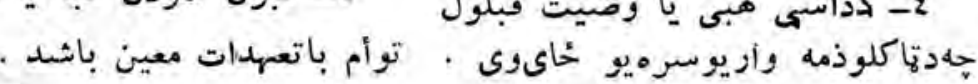
- TVV ماده olrvV

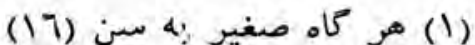
ته (1)

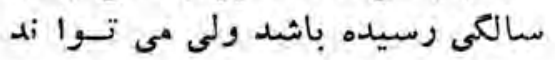

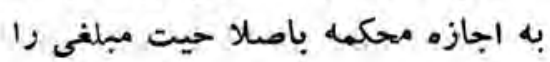
براى تجارت بدسترس وى بكذاره ودارد.

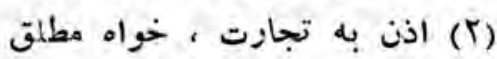

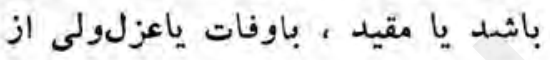
بين نميرود . بالمد مقيد

$$
\text { - rVA ماده }
$$

ته رسيدلى وى، ولى كولى شيى جلى

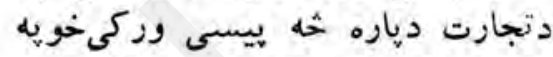

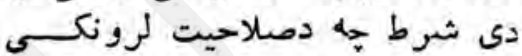

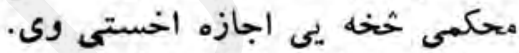

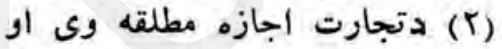

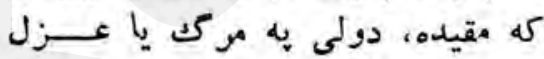
دمينخه نه نه

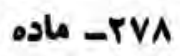

تصرفات صغير ماذون دز حدوديكه محكمه باصلاحيت دراموالوىمجازقرات داده است، بمنزله تصرف شخهيست دراحيست

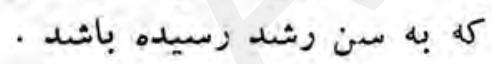
- rva

دماذون صغير تصرفو نه يه هنه

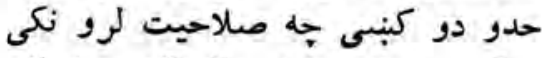

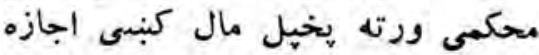

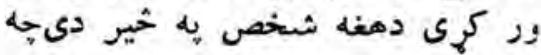

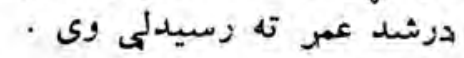

$$
\text { ماده }
$$

بدر مىتواند عقدى راباسم شخص

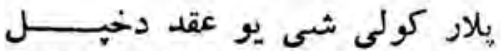

تحت ولايت خويش بحساب خود يو يانديا شخص ديكرى انجام دمد . . مكر ايذكه قانون خلاف آن حكم كرده باشد ديد .

$$
\text { ماده - }
$$

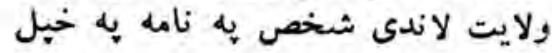

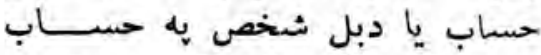

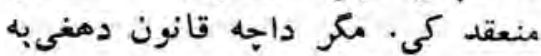

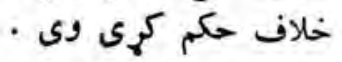

يدز كلان نمى تواند بدون اجـازه

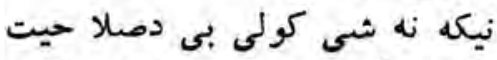

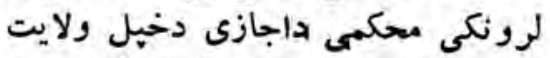

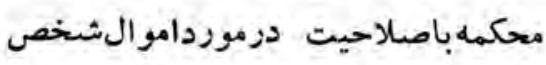

$$
\text { خاف - }
$$

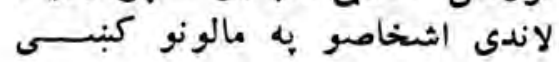


تجت ولايت خود تصرف ياصلحمبنى

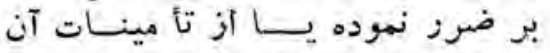
انصرواف و ونا در تأمينات ثقليل بعهل

\section{ماده}

ولى مكلف است فهروست مكمـل

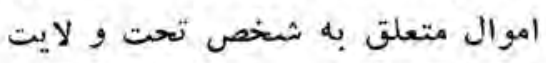
خودزا در ظرف دو ماه از آغاز ولايت لهايت

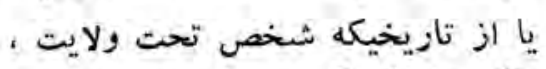

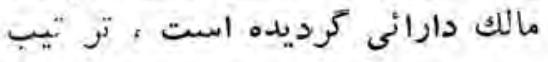

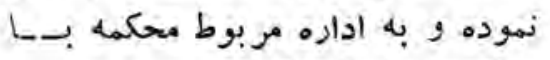

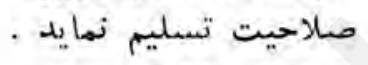$$
\text { - rar }
$$

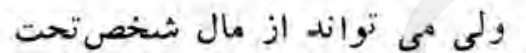

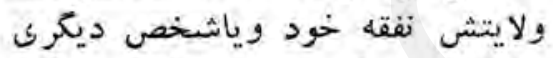

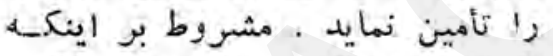

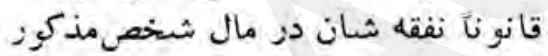

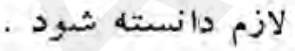

$$
\begin{aligned}
& \text { - }
\end{aligned}
$$

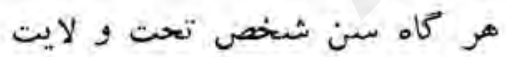

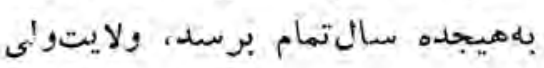

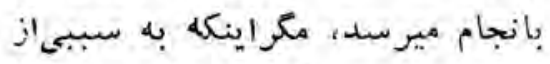

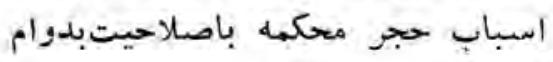

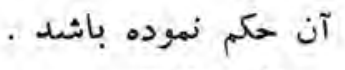

\section{- TAE}

هر كاه نسبت سوء تصرف وله مادى

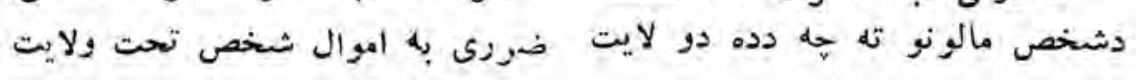

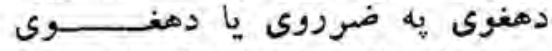

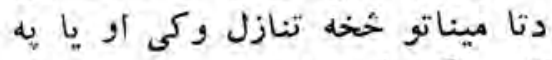

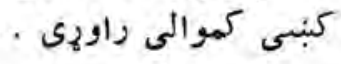

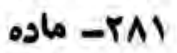

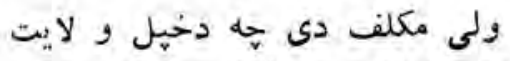

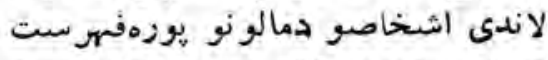

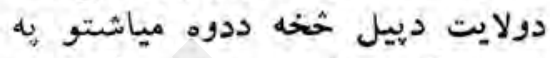

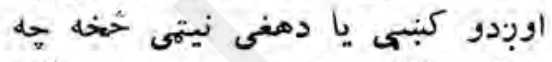

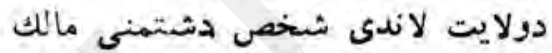
شوى ترتيب كى او دصلاحيت لرونى نكى دونى

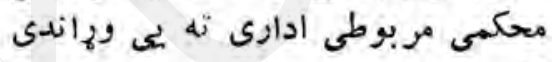

\section{r for}

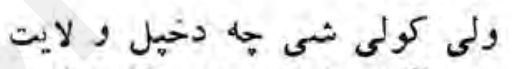

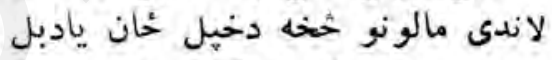

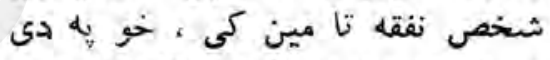

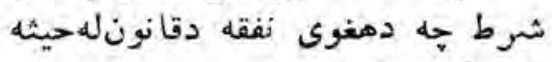

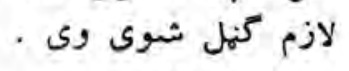
rar

كه دولايت لاندى شخحص عهم نوره

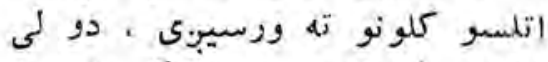

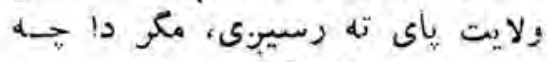

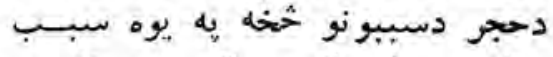

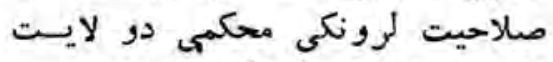
. Dlo - rAE

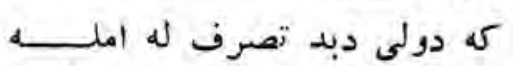




\section{sole (YAA-YAO)}

دوهـم فصل - اشغخاص

متوجه باشد ، محكمه مى تواند ولايت

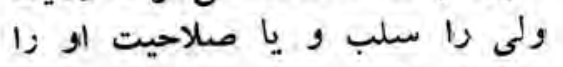

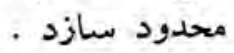

\section{ماده}

هركاه ولى غايب شنا خته شده

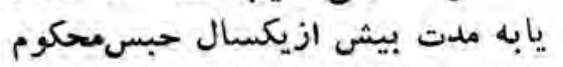

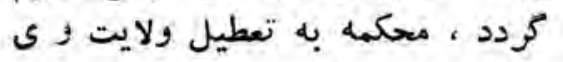

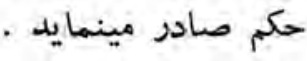

$$
\begin{aligned}
& \text { - ماده }
\end{aligned}
$$

در صورتيكه ولايت ولىطبتمواد

(VAO، TAE)

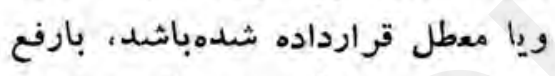

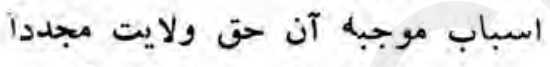
بقرار محكمهباصلاحيت اعادهميكردد.

$$
\text { - rAV ماده }
$$

هيلز از خسارات ناشهى از خطاى

فاحش خود بر اموال شخص تحست ولايت مسئوليت دارد . مسئو ليت بليت

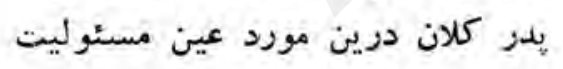
وصى ميباشد .

\section{ماده PAA}

وللى ياورثه او مكلف انده 1 مـوال شخص تحت ولايت را حين رسيدناو به سن رشد ، به به ود تسليم نمايد. ودر صوزت تصرف ، قيمت مال را طبق نرخ روز به وى بير دازد .
لاندى دى ضرر متوجه شبى ، محكمه

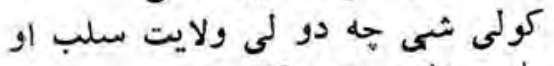

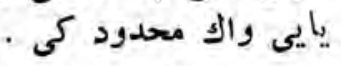
ol rAO كه ولى غايب وكنهل شبى يا ديوه

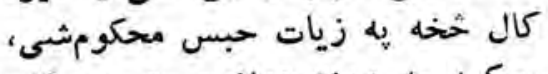

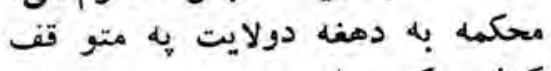
كولو حكم صادر وى كו

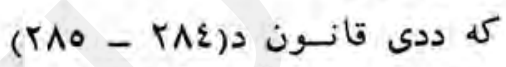

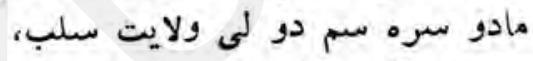

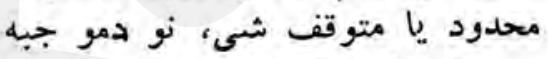

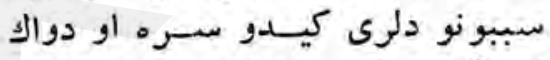

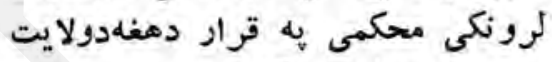
حق بيرته اعاده كيبرى كاد - rav

كه ديلاز دفاحشو خطاكانوله امله دشخص مالونو ته جه يـ دو لايست

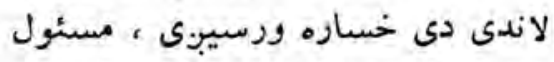

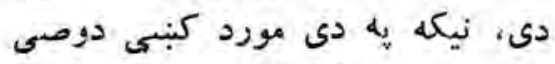

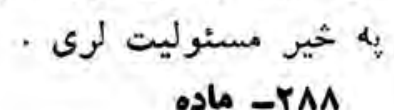

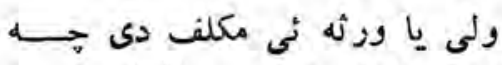

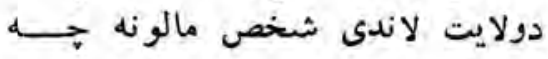

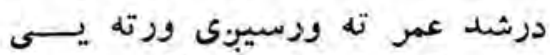

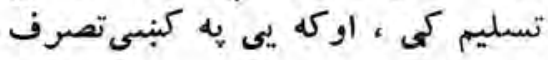

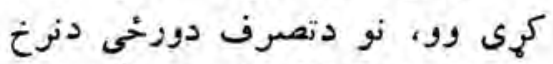
سره دى سم دهغى قيمت وركى نو دونى دن 


\section{مادي (49.-2A9)}

لمهى قسمت - حقيقى شغص

$$
\begin{aligned}
& \text { جزء دوم - وصايت } \\
& \text { اول - تعيين وصى } \\
& \text { ماده - r }
\end{aligned}
$$

$$
\begin{aligned}
& \text { دوهم جزء - وصايت } \\
& \text { اول - دوصى تهاكل } \\
& \text { اول - rA9 }
\end{aligned}
$$

وصى بايد ثنحص عادل ، باكفايت

وواجد اهليت كامل بوده با شتخصيخا

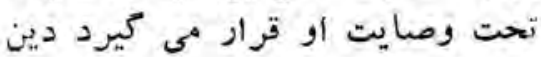

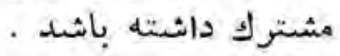

$$
\text { - rq. }
$$

اشخاص ذيل وصى تسعيين شده

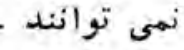

1- شخصيكه بحكم قطعى محكمها به

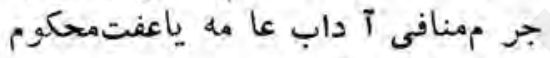

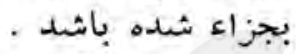

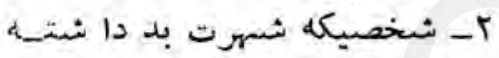

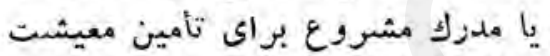

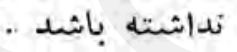

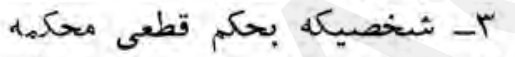

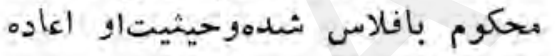
نشيله بانشمد

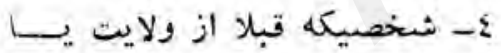

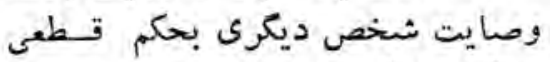

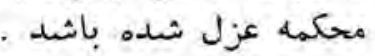

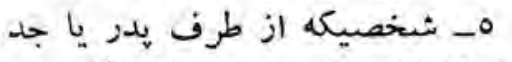

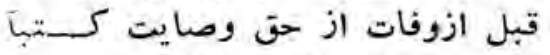

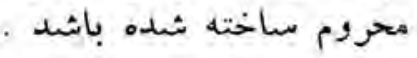

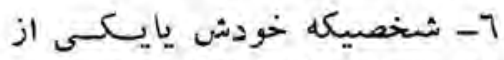

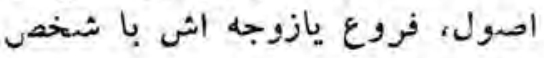

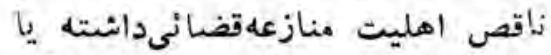
جنان اختلاف فا ميلى مرجود باشيدئه

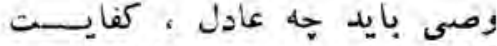

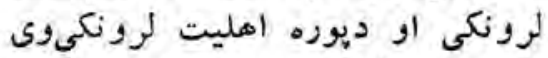

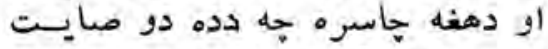
لاندى واقع كيبزى شريك دين ولرى. دون. (

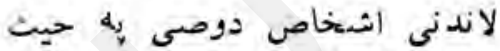

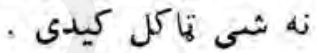

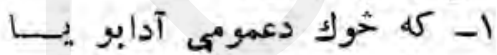

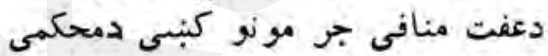

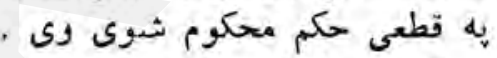

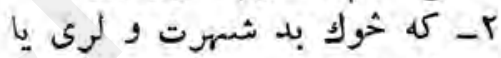

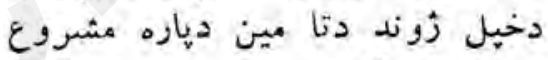
سبب ونه لرون لد دونا با

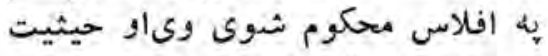

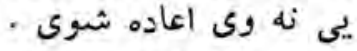

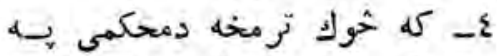

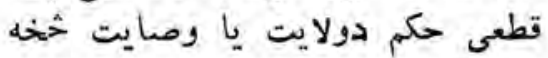
عزل شوى وى .

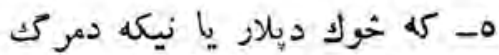

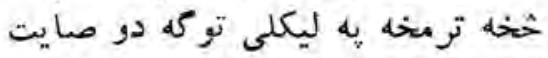

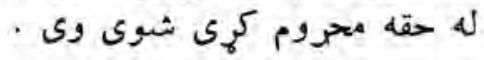

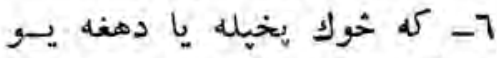

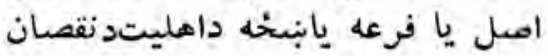

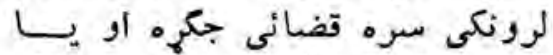

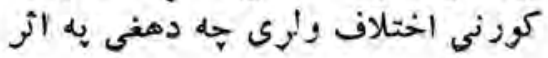




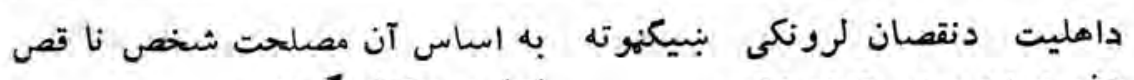

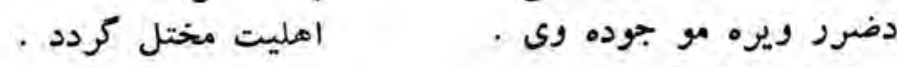

$$
\begin{aligned}
& \text { دوم - وصى آ محتى اختيادى }
\end{aligned}
$$

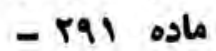

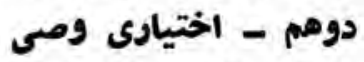

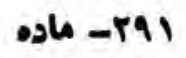

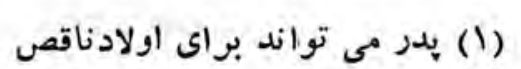

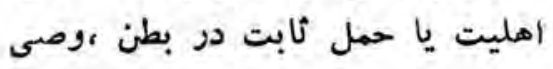

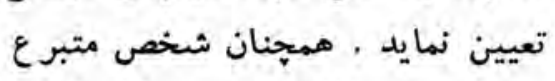

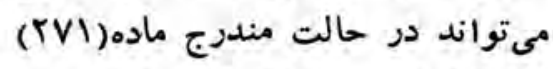
اين قانون وصنى اختيار نمايد . ماند ماده ماده

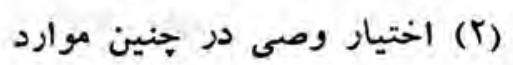
توسط وصايت خط رسمى يا عرفى وصى دورين

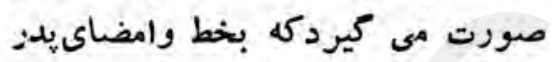

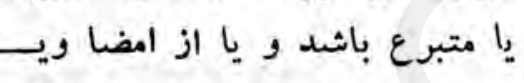
شصت شان در جنين اسنادتصديق

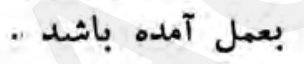

$$
\text { - rar }
$$

بدر ومتبرع مى توانند در مورد مود

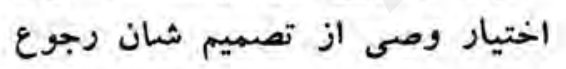

$$
\text { نمايند اختيار وصر }
$$

\section{- rar oslo}

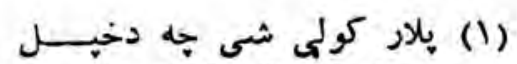

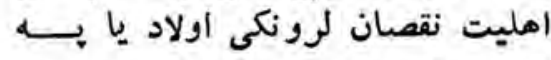

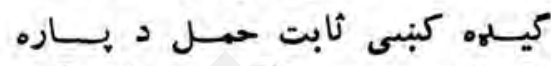

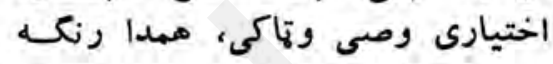

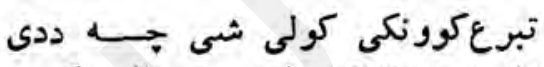

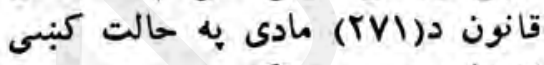
اختيارى وصى وتاكى دونى مادى

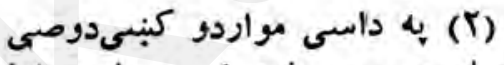

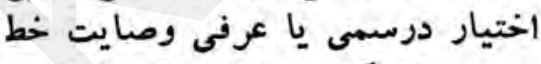

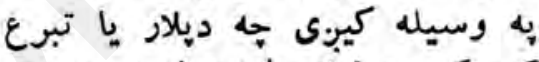

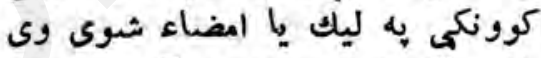

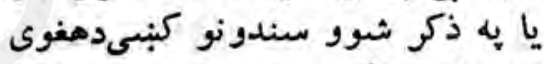

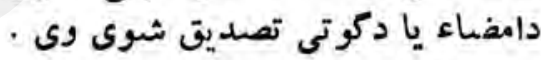

$$
\text { بلrar }
$$

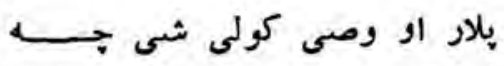

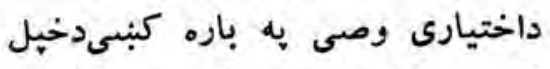

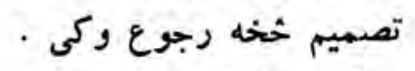
oslo - rar كه جا دوصيت كوونكى به زوند شخصيكه وصايترا درحينحيات

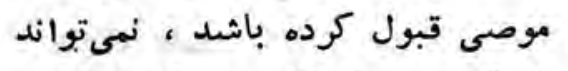

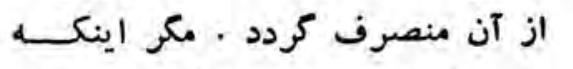

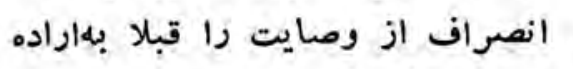

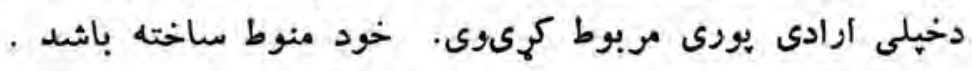




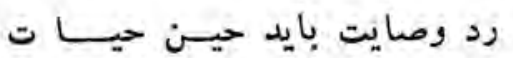

دوصايت رده ول بايد جهدوصايت

موصى صورت كرفته وباطلاع و ى

رسانيده شود . مورت

ماده

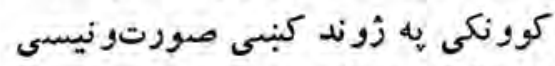

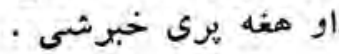

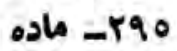

شخصيكه وصايت را طبت 1 حكام

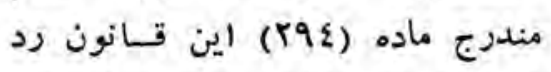

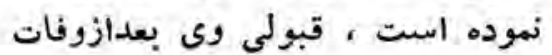

موصى اعتبار ندارد

- ماده

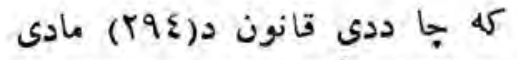

ددزج شوو حكمونو سره سموصيت

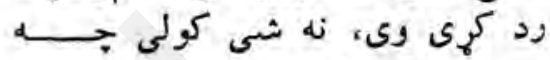

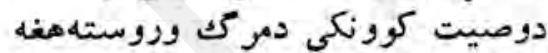

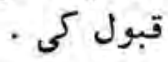

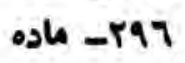

اختيار وصى وقتى نافذ شعر ده ماده

دوصى اختيار هغه وخت نافذكنل

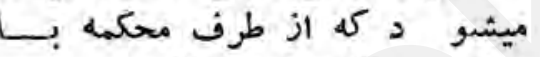

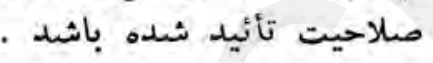

\section{سوم - وصى قفائى \\ - rar as}

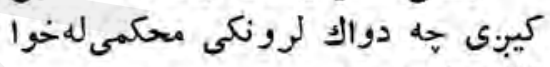

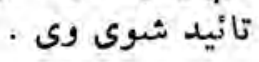

هر كاه براى شتخص نافصناهليت

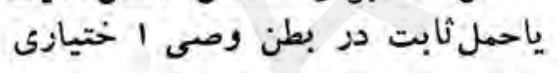

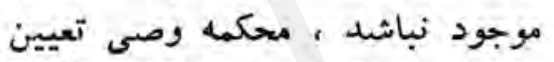

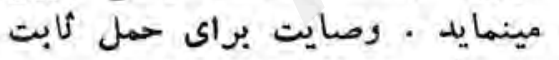

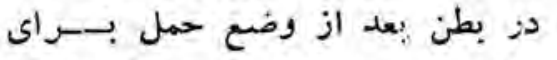

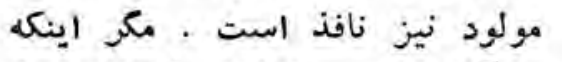

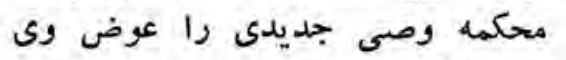

$$
\text { تعيين كرده باششد }
$$$$
\text { دريم - قضائى ومى ثلى }
$$

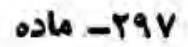

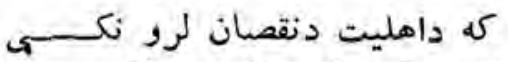

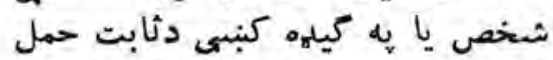

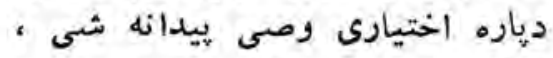

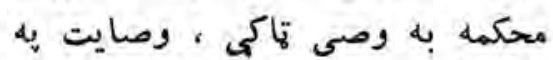

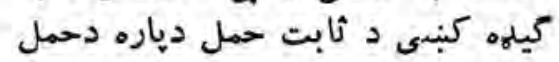

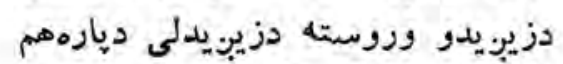

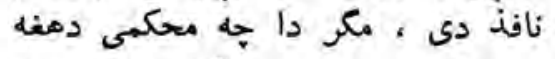

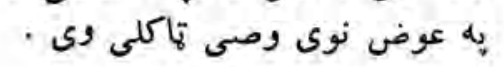

$$
\text { A }
$$

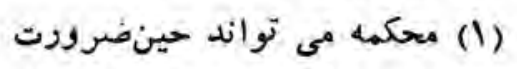

(1)

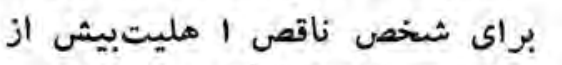

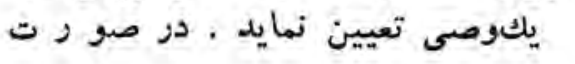

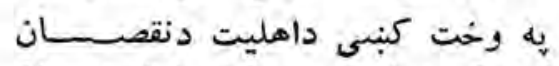
لرونكى دياره ديوه خخه زيله دياتوصيان 
تعدد وصى ، او صيا نميتوانند در

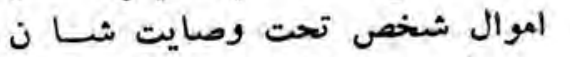
منفرداً تصرف نمايند . مكرو اينكه

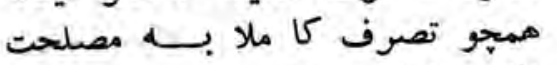

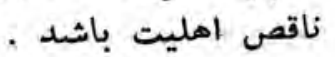

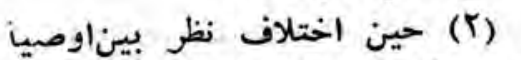

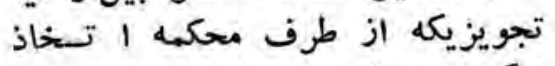
ميكردد ، قابل تعميل مى مياشد ماند . - ra9 مادل محكمه در حالات ذيل وصى خاصه

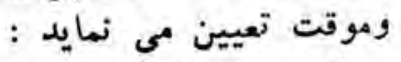

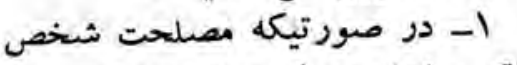

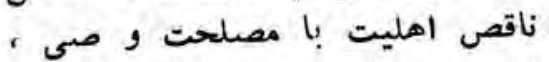

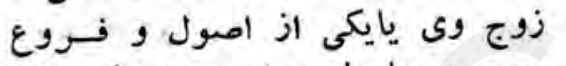

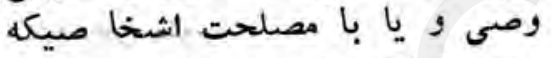

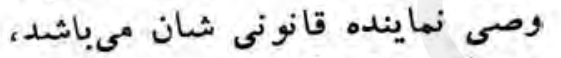
متصادم واقع كردد نمانده قونى اهلr

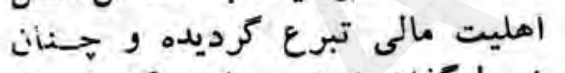

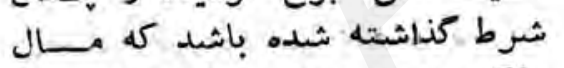

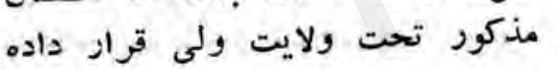
نشود ، مدكور تح

اون- در صورتيكه أجراى وصايت

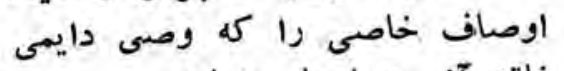

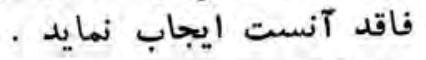

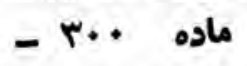

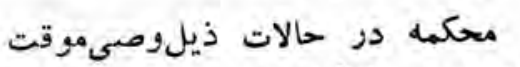

$$
\text { تعيين مى نمايد : }
$$

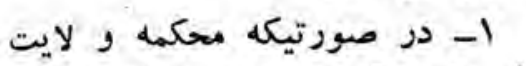
ولى را متوقف نموده و شخص ناقص معلى
وتاكى ، وصيان نه شى كولى دخيل

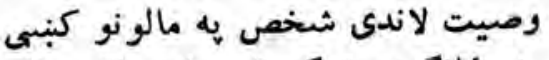

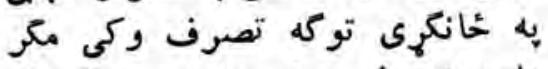
داجه تصرف بيخى داهليت دون دنقين تصني

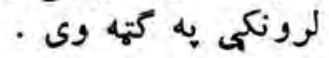
(r)

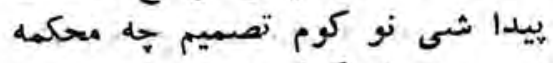
ن نيسى دعمل كولو نو 99 به لاندنيو حالونو كبنى بهمحكمه خأص او موقف وصى تاكى : الدئ

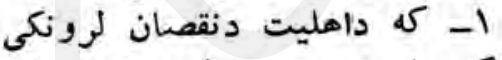

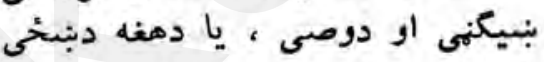

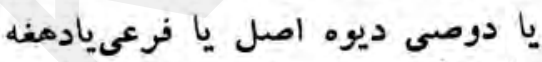

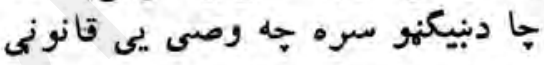

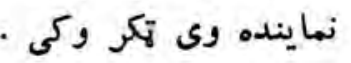

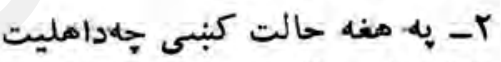

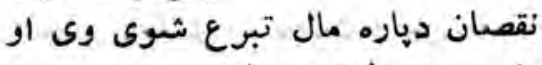

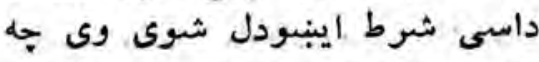
ذكر شوى مال دى دولى دولايتلاندى الينودي زه ايبنودل كيبوى مال دى دول

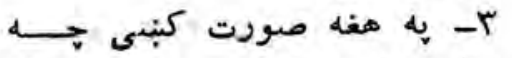
دوصايت اجراجهدايهى وصى وصى دهني دخاصوصفتونو فاقد دى ايجابكائى وصى. (...

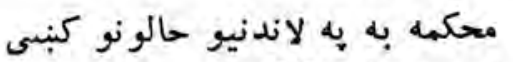
موقت وصليى تاكى به لاند

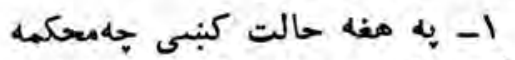
دولى ولايت متوقف كى او داهليت جاليت 
نقصان لرونكى بل ولى ونه لرى . اهليت ولى ديكرى نداشته باشد .

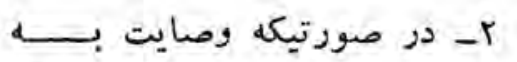

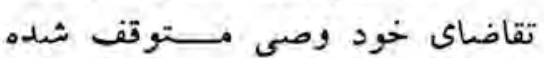

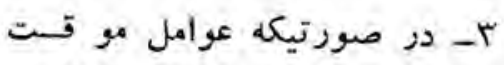

مانع اجراى وصايت كرديده باشهد.

$$
\text { ماده ماجع }
$$

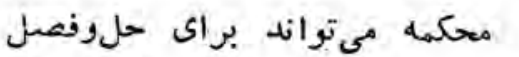
دعاوى مربوط به شخصن ناقصاهليت وصى خصو مت تعيين نمايد، كرجها

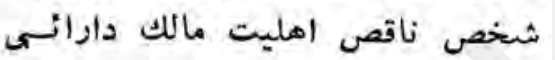

$$
\text { ماده }
$$

وصى ثى تواند دو تمام هوارديكـــ

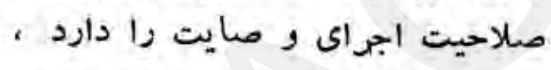

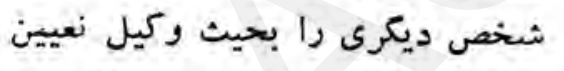

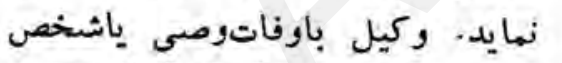
تحت وصايت معزول شينا خته ميل شود " مادو

\section{ماده r.r}

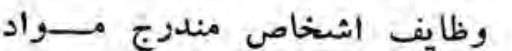

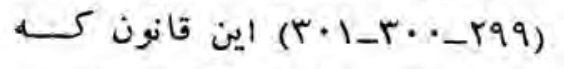

بحيث وصنى تعيين كرديدهاندوقتى

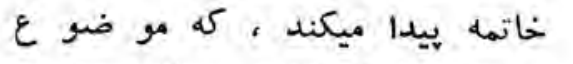

وصايت انجام يافته و ويا مدته معينها

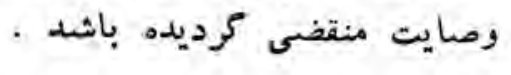

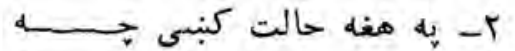

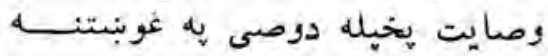

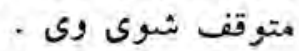

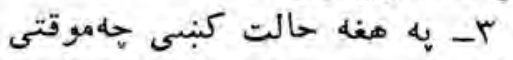

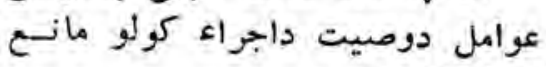
كرخيدلى وى 1

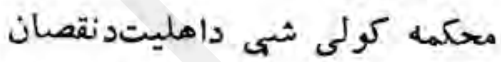
لورونكى ددعوو دحل او فيصلى وديازه

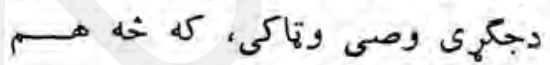

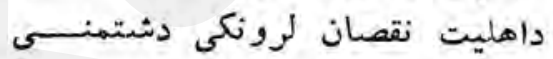

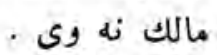

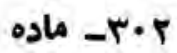

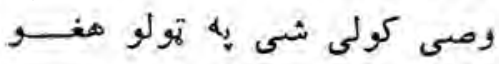

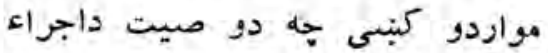

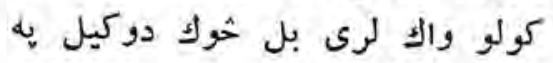
حيث وتاكى ، وكيل دوصى وصى دمرك لرك

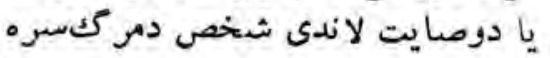

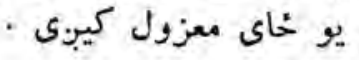

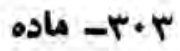

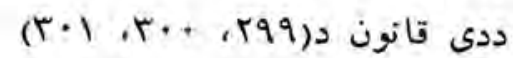

مادو ددرج شور اشخاصو وظيفى دونه

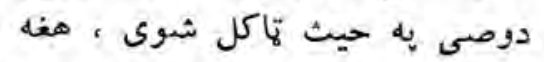

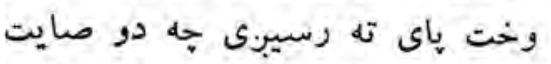
هوضوع ترسره شوى وى يادوصايت

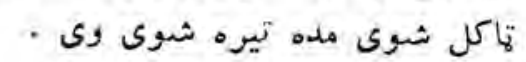


جهادم - مكلفيت ماى وصى

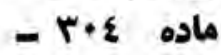

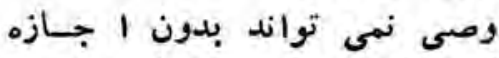

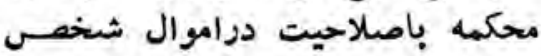
تحت وصايت تصرفات ذيل ذرابترابعهل

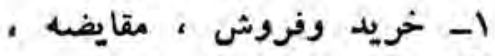

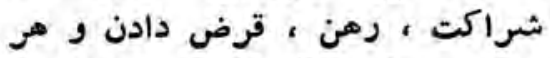
نوع تصرف ديكريكه موجب اكت انتقال

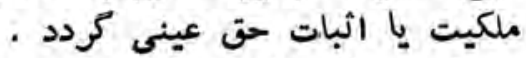
r- حواله دادن دينيكه شخــ ناقص اهليت بذمه شخص د د يكر ى دارد ويا قبول حواله دين عليه اونه

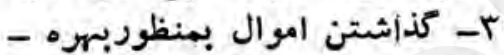

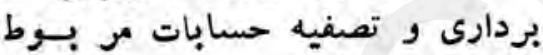
بهآن ياقرض كرفتن بحساب شخص ناقص اهليت . آرضي عـ- اجاره دادن اموال غيت غير منقول

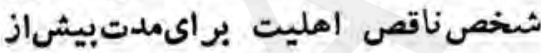

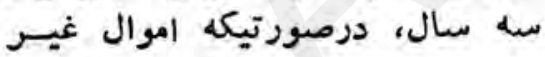

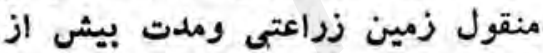
يكسال درصورتيكه اموالغير ومني منقول عمارت باشد . عارص

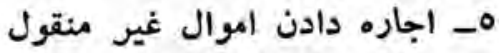
شخص ناقص ا هاره داد انيت برال غير مدتيكه

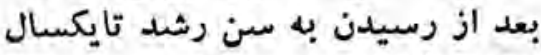
دوام نمايد. 7- قبول يارد تبرعاتيكه مشروط بشرط باشد ق بول

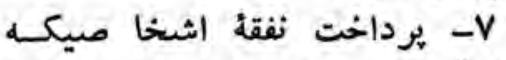

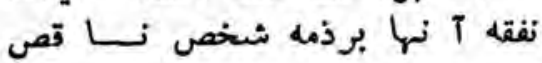

خلودم - دوصى مكلفيتونه

$$
\text { ع •r- ماده }
$$

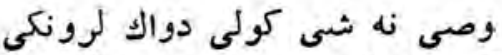

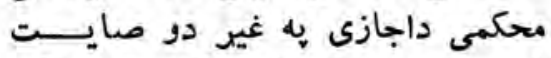

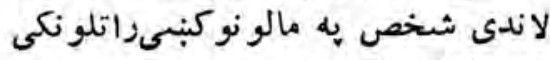
تصرفونه وكى : آنس

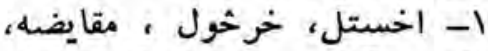

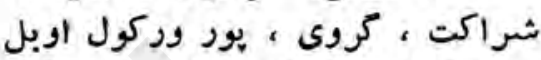

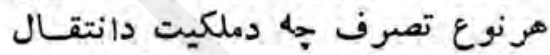

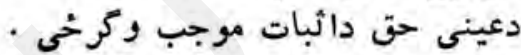

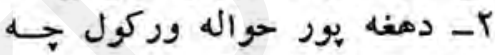

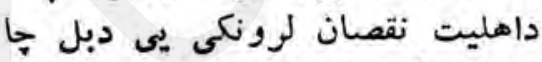

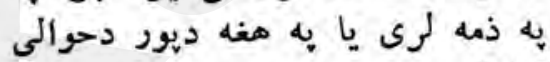
- قبلول دمه

به

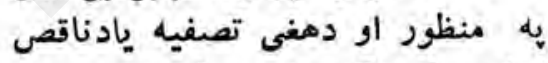

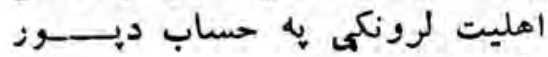
اخستل . أمليت كورن ع- ددرى كلونو خخه دزياتىمدى

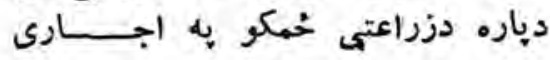
وركول، او ديوه كال شخه دزون دوزياتى

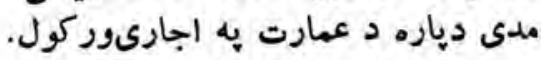

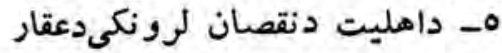

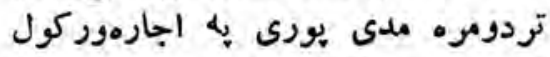

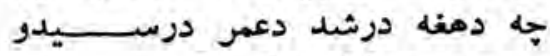

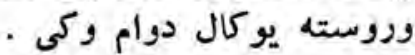

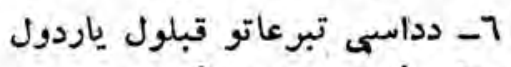

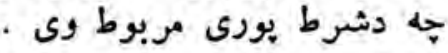

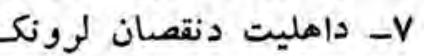
دشتمنى خخه دهغه جا نفقه ورنه لرون 
اهليت لازم است ، مكر اينكه نفقه

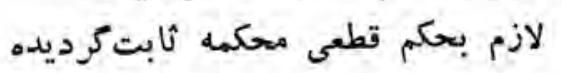
باشلد . بارم

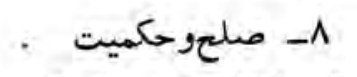

9- ايفاى تعهدات كه بر متروكه

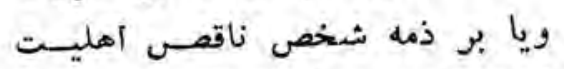

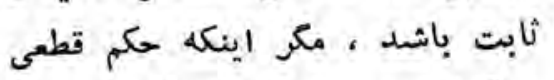

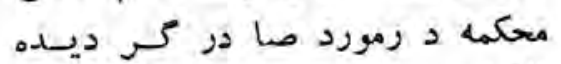

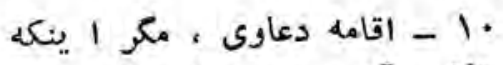

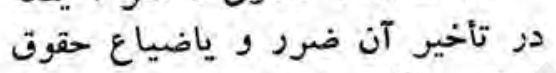

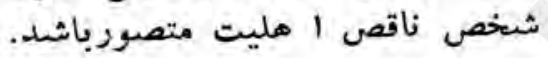

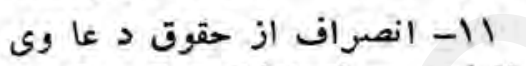

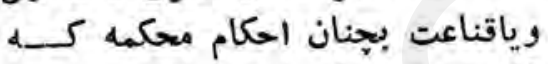

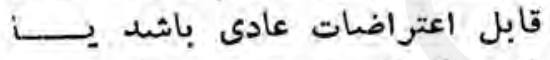

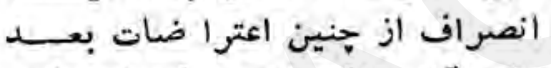

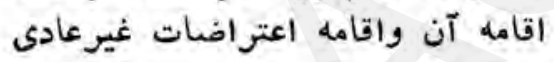

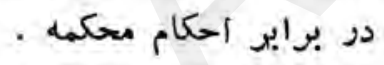

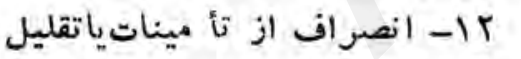

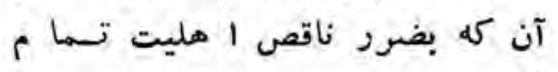
شود .

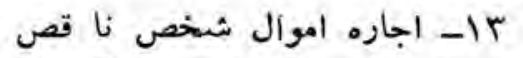

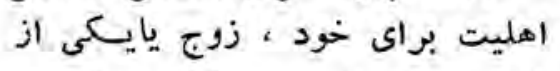

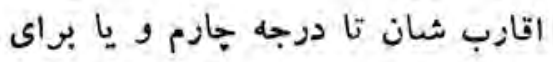
كسى كه وصى نائبوىباشيد. عا- يو داخت مصارف از دواج شخص ناقص امليت
جه به ذمه يق لازمه ده، مكر دا جه جه

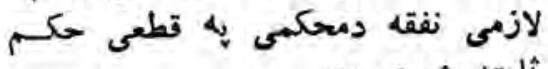

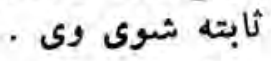

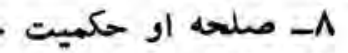

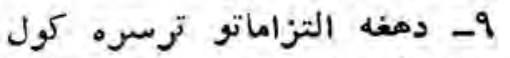

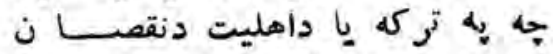

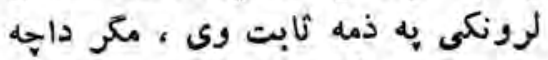

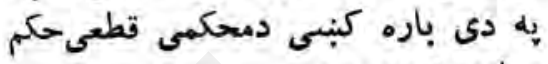
صادر شوى وى لهاره كيني

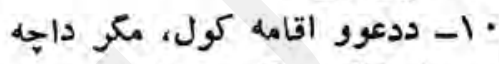

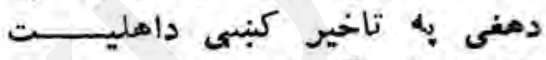

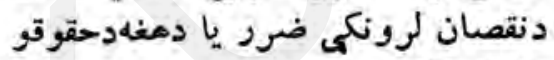
دضايع كيدو ويره ونى لرون

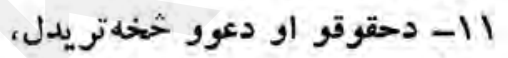

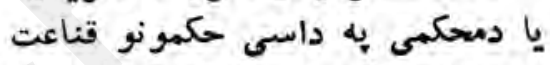

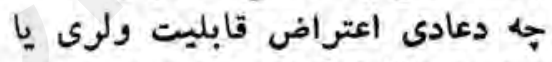
ددعوى داقامه كيدو وروسته دواعته

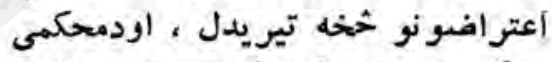

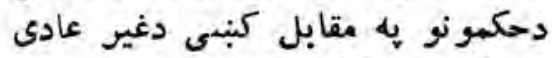

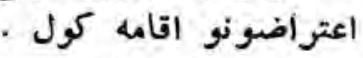

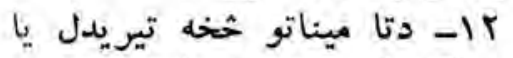
دهغى كموالى يه دى شروط جها ميه دامليت

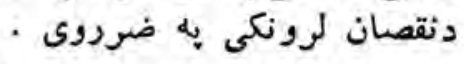

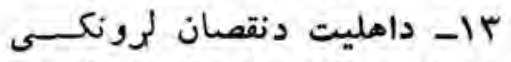

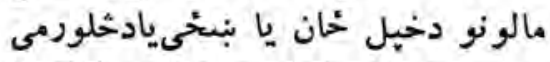

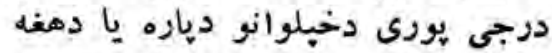

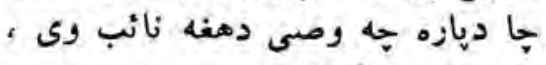
يه اجاره وركول

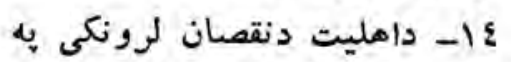
واده مصرف كول 
10- بر داخت مصازف تعليمى و

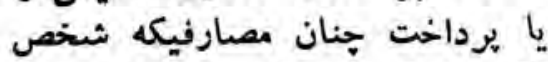
ناقص اهليت در اجراى شيغل معين ماخد مارد

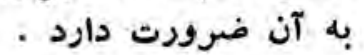

$$
\begin{aligned}
& \text { ماده }
\end{aligned}
$$

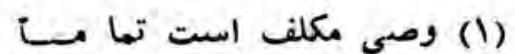
عايدات نقدى شخص تحت ور ورايت

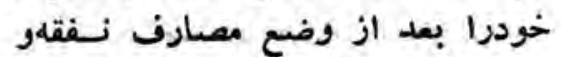
مصنارف متفرقهايكه از طرف مون محكمه

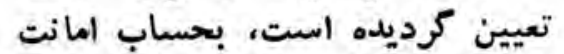

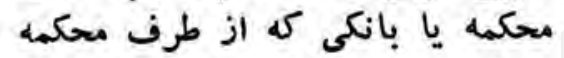

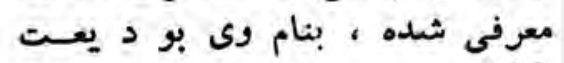

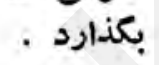

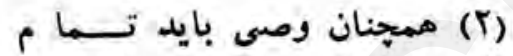

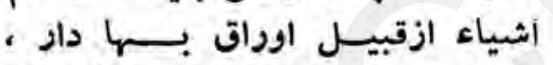
زيورات ، جبواهرات وامثال آ نسرات

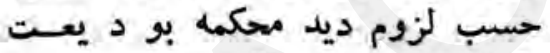

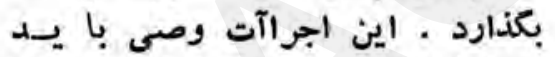

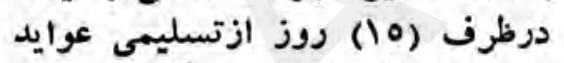

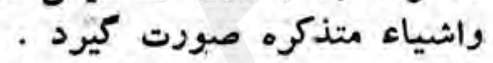

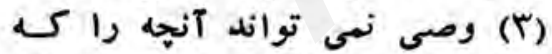

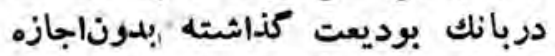

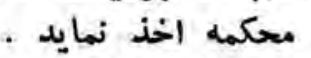

$$
\text { - r.y }
$$

وصى مكلف است دعاوى را كـه

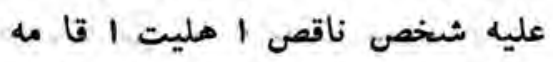

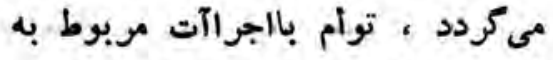
آن ، باطلاع محكمه رسانيدهواوام محكه را در مورد نييروى نمايد.
10- دتعليمى مصر فونو يادداسى

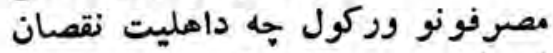

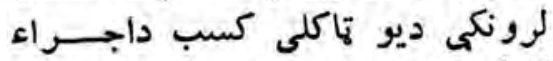

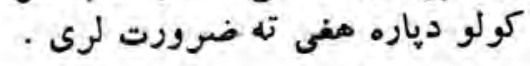

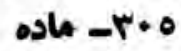
(1) وصى مكلف دى جه جه دوصايت

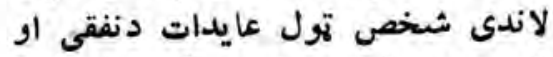

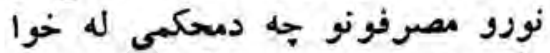

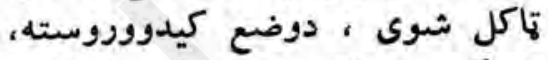

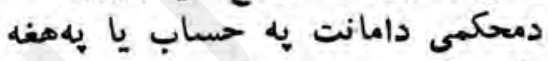

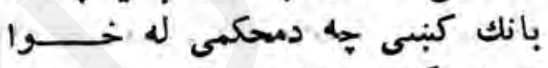

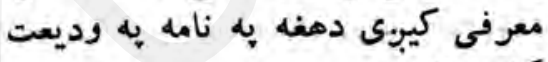

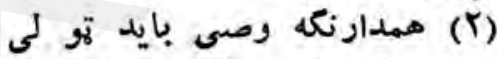

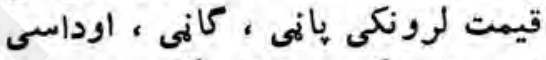

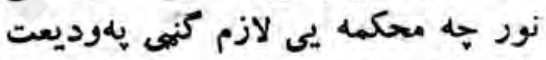

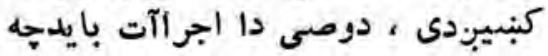

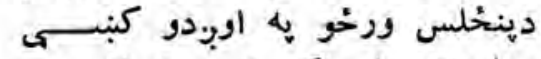

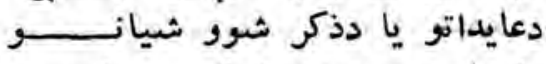

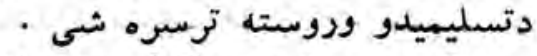

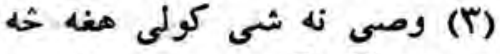

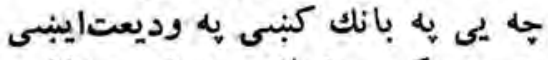

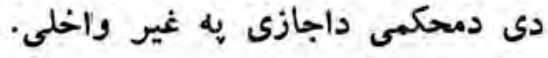

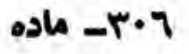
وصى مكلف دى جه كومى دعو ى

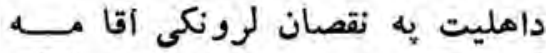

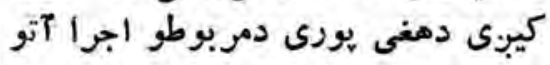

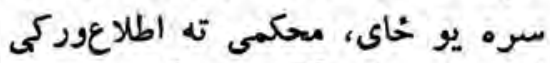

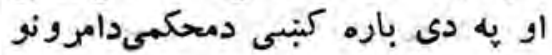
• نييروى وكى دئ 


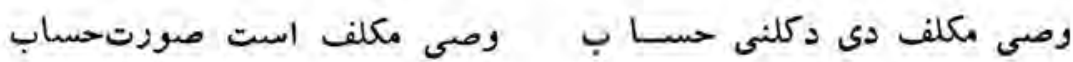

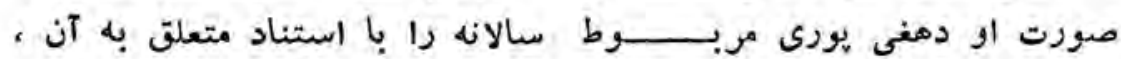

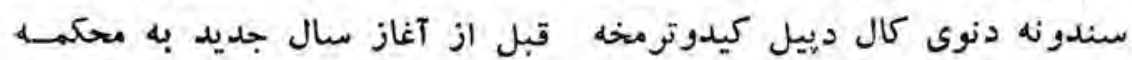

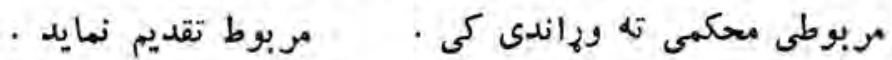
ماده

$$
\text { A }
$$

هر كاه دارائى شخصت ماده

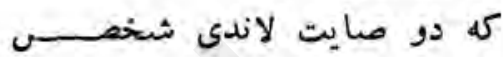

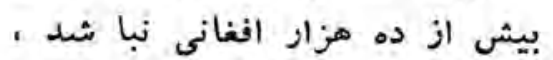
هجكمه مى توائد وصى را از ترني

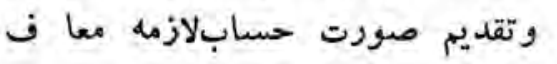
نمايد و ونقد

\section{- r.9 ماده} شتهنى دلس زرو افغانيو خخه زياته

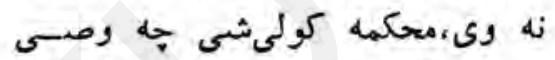

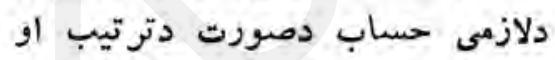

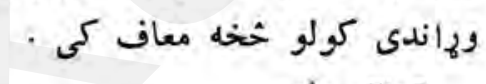
هركاه شخص ديكرى بعوض ماهو

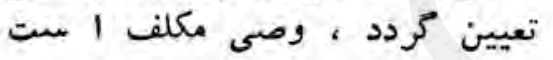

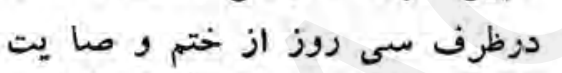
صورت حساب متعلق باموال شخص رون

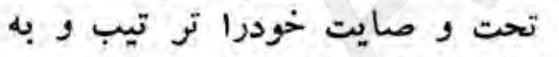

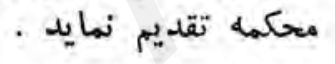

ماده

$$
\text { 9 }
$$

كه دوصى بر خاى بل خوكثوتاكل

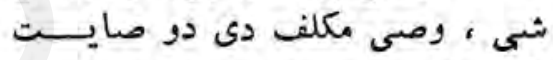

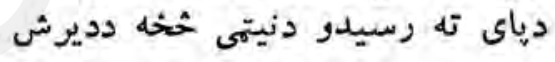

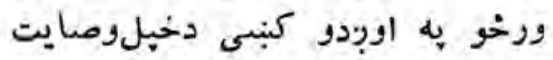
لاندى شخص دمالونو دحسابصورت اوني

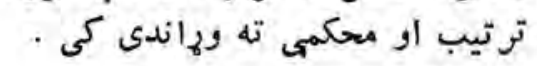

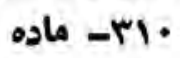

اجراى وصايت بدون 1 جرتمى ماده دوصايت اجراء كول اصلا بى له

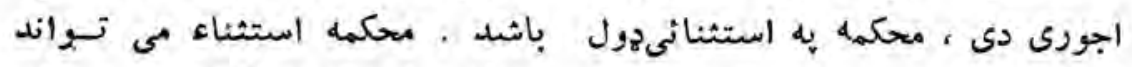

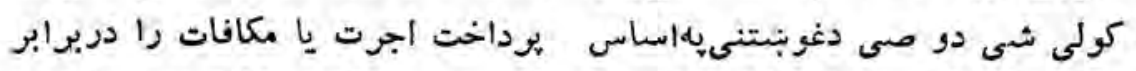

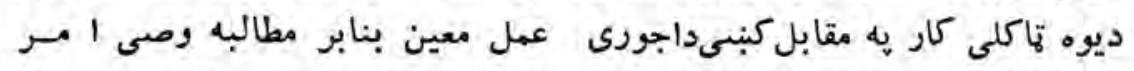

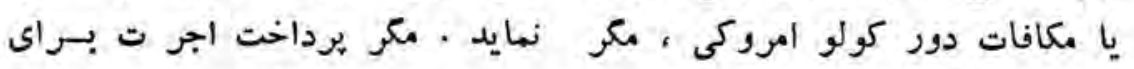

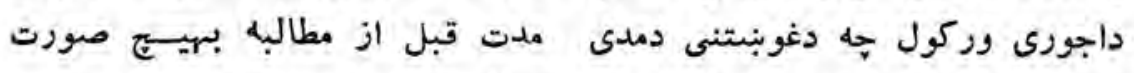

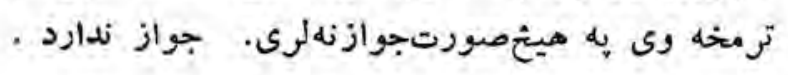




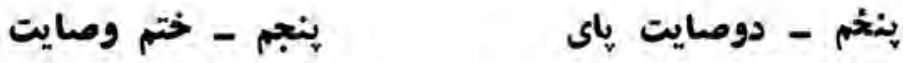

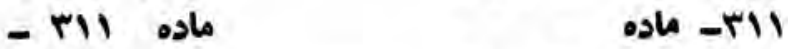

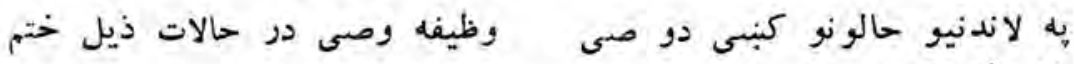
وظيفه باى ته رسيبوى : :

1- و و فات شخص ناقص اهليت.

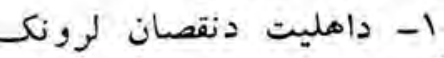

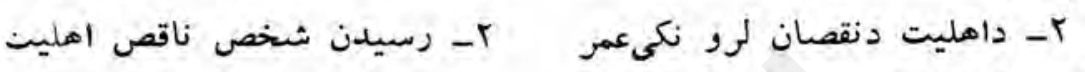

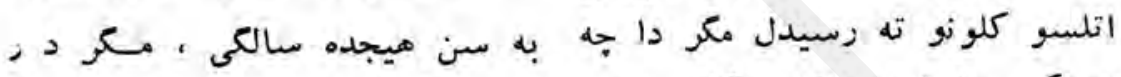

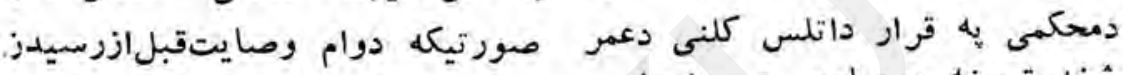

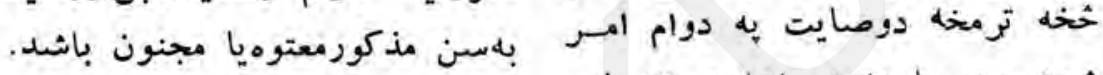

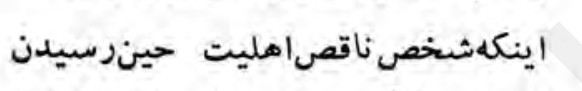

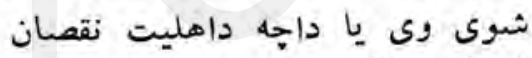

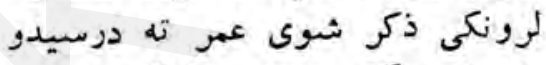

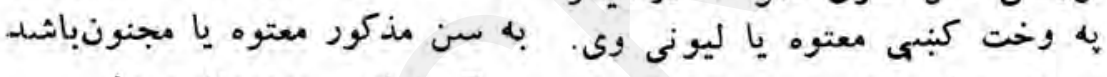

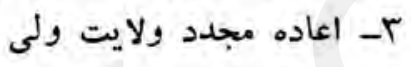

$$
\begin{aligned}
& \text { r- دولىدولايتبير ته اعادهكيدل. }
\end{aligned}
$$

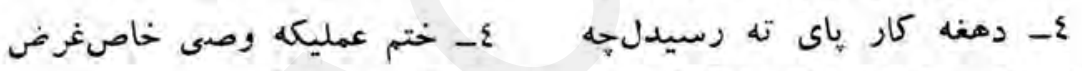

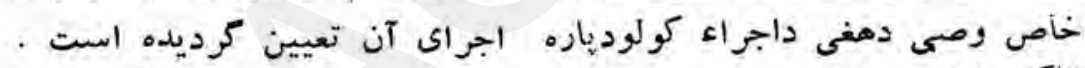
• - عزل و صى ياقبول استعفاى لعين وى

7- فقدان ا هليت قانونى و صـ وفي ياغياب ويا وفات وى .

$$
\text { - ماده }
$$

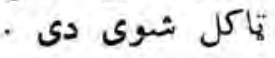

0- دوصى عزل يا دهغ ديه داستعفى

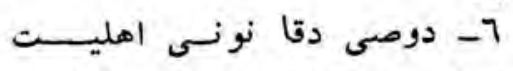

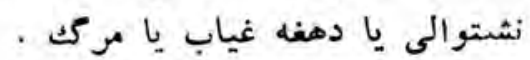

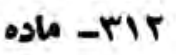

وصى دزحالات ذيل عزل ميكردد :

1- هر كاه سبيى از اسبابحرهن وصى به لاندنيو حالونو كبنسى عزل كيبى : وصى

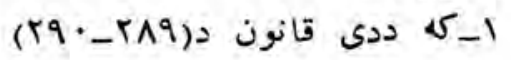
وصايت مندزج مواد (r^9) ( مادو دوصيت خخه دمحرو ميدو ددرج شوو سببونو خخه يو سببيداشى. اين قانون موجود كردد . 


\section{(rio_ritr)}

لمدى قسمت - حقيقى شخص

r- اكر دز اداره اموال شخصى

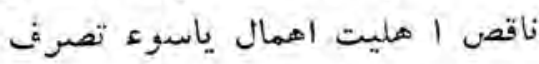

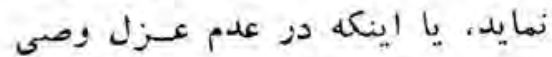

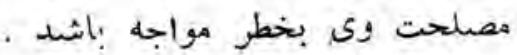

$$
\text { ماده }
$$

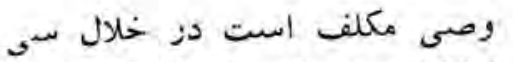
زوز ازختم وصايت اموال تحتادازه

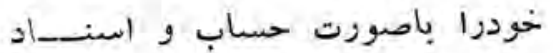

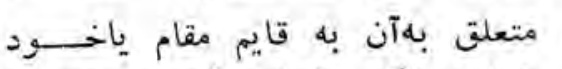
شخص ناقص أهليت كه بهآسن زئس رسيده باشد ويا در صوريت وفات

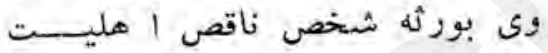

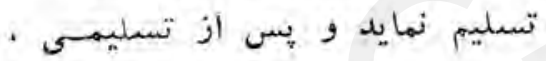

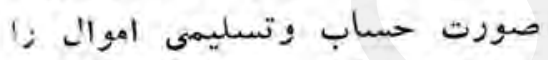

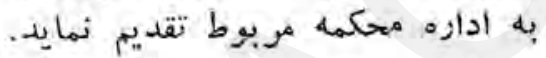

\section{ماده}

هر كاه وصى وفات نمايسد يــــا

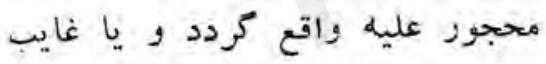

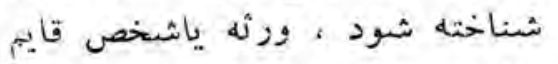

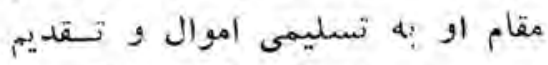

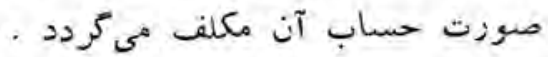

\section{ماده}

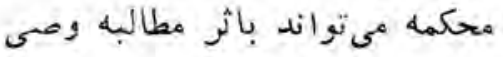

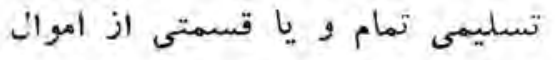

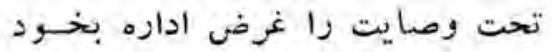

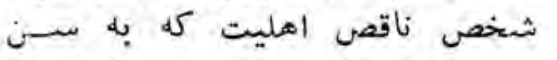

كان

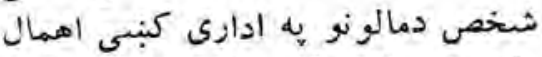

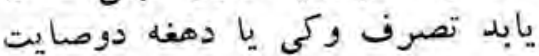

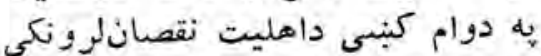

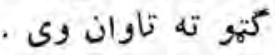

\section{rוr- ماده}

وصى مكلف دى دو صايت دياي

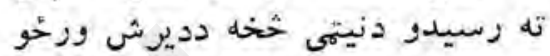

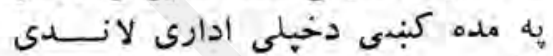

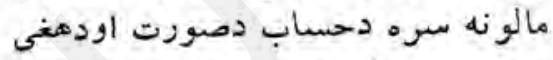

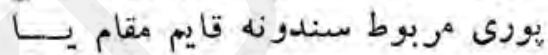

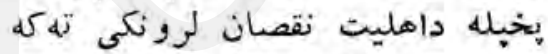

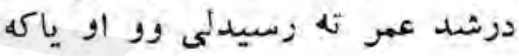

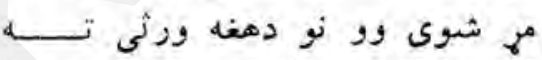

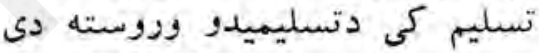

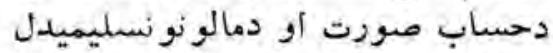

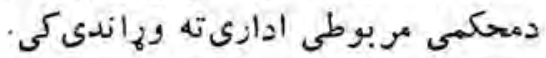
Sاد

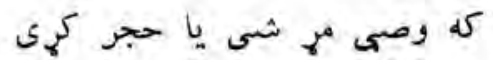

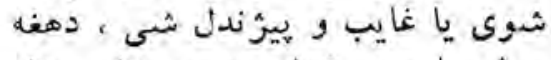

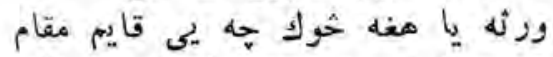

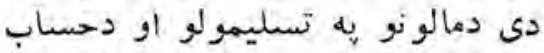

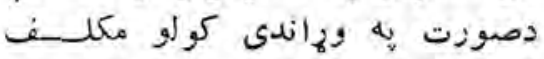
كي.ب.

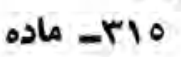

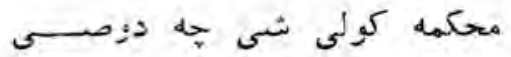

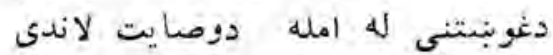
تول يا يوه حصد مالونه دادارىكولو

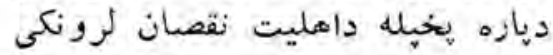




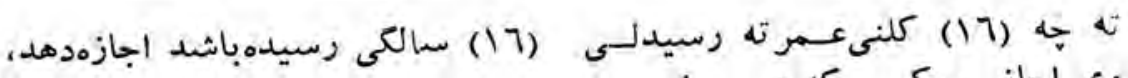

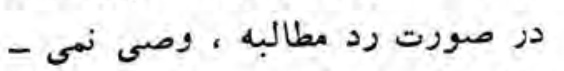

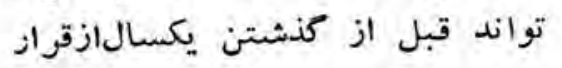

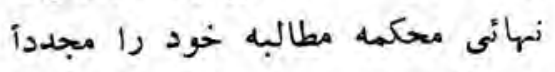

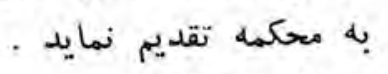
ماده

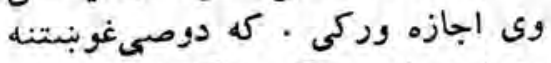

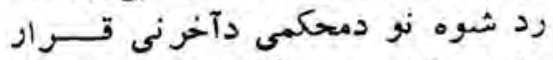

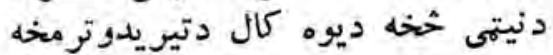

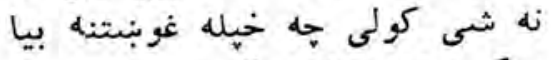

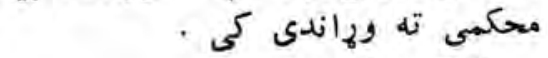


تعهد ياابراء شخص ناقصاه رنهليت

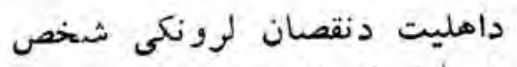

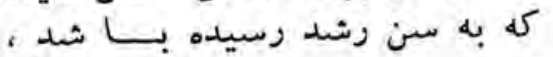
بمنفعت وصى و قتى اعتباز دارد كم رديده

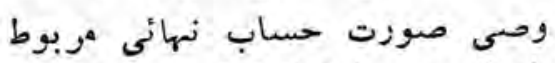

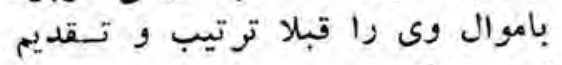
نهوده باشد وي رال

\section{ماده}

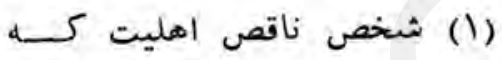
مأذون به ادازه اموال باشد، مكلف إمليت است صورت حساب سالانه اموا"

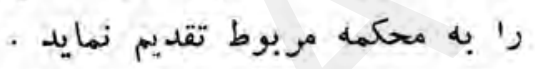
محكمه نظر و صى را حين د سيدكى

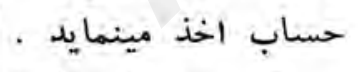

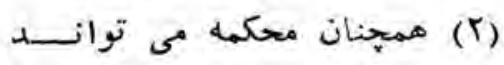

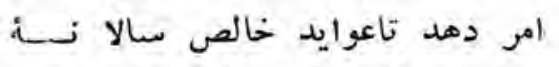

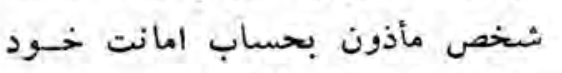
محكمه يايكى از آنها طوريس انداز بحان

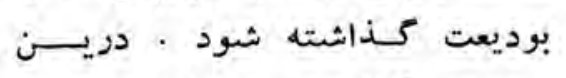
صورت مأذون نمى تواند بـدون اجازه محكمه از آن استفاده نمايد.

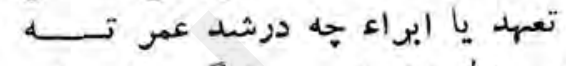

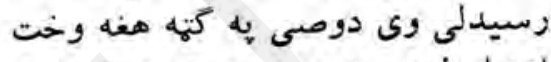

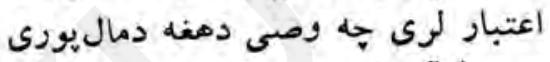

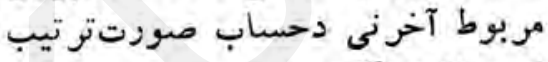

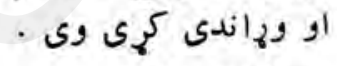

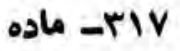

(1)

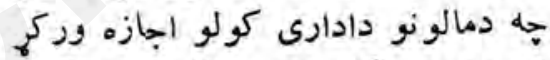

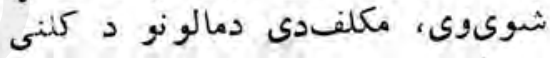

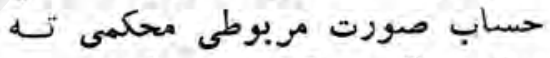

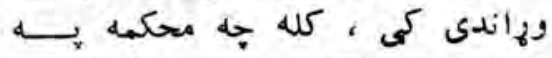

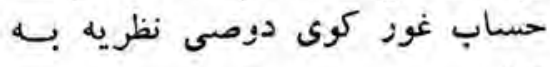

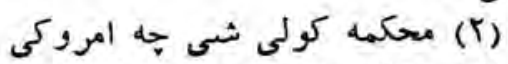

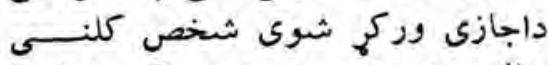

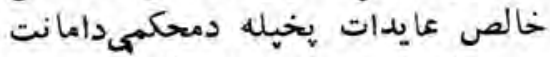

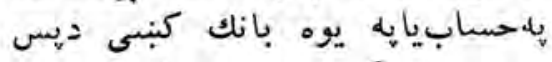

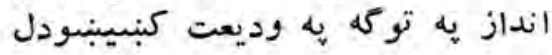

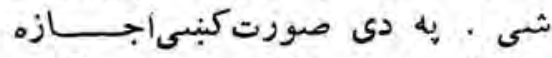

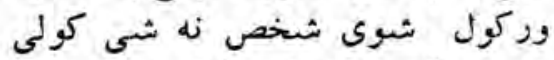

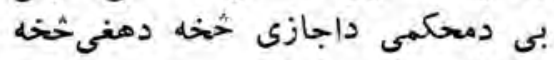
استفاده وكى دمى دمى 


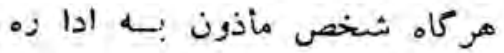

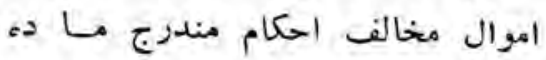

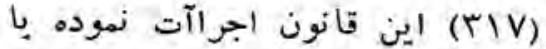

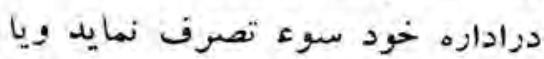

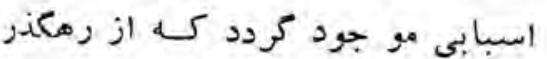
دوام تصرف شخص مأذون امسورال تحتادارهوى مواجهبه ضررى باشد،

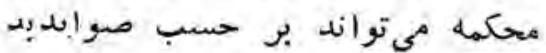
خود ياباثئ مطالبه خارنوال يا يكى از الشخاص ذيعلاقه يس از الستهاع

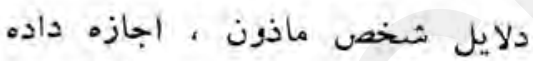

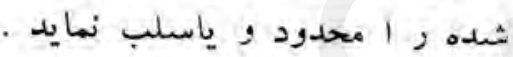

$$
\begin{aligned}
& \text { جزء سوم - حجر } \\
& \text { - ماده }
\end{aligned}
$$

(1) شخص بالغ بهسبب جنون؛

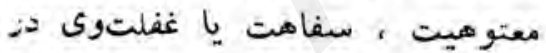

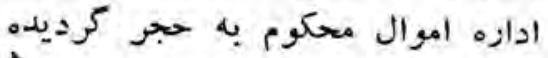

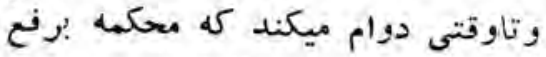
آن حكم نه نموده باثلد موام ميله

خص (r) شخص محجور عليه ، مطابق باحكام

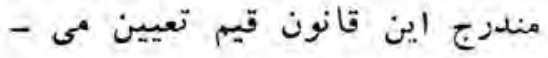
نمايد.
كه اجازه وركول شوى شخديس

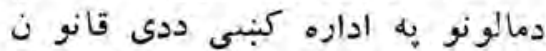

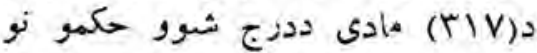
به خلاف اجرآت وكى يا يخيلهاداره

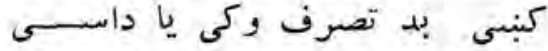

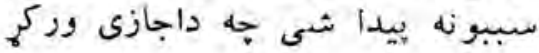
شوى شخص دتصوف ددوام للهامله دهغه دادارى لاندى مالونه دضرزسره

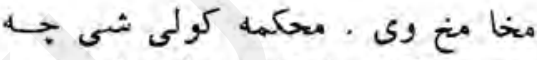

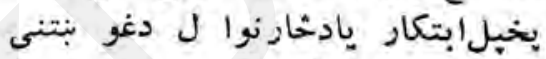

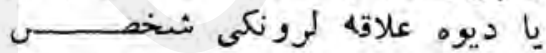

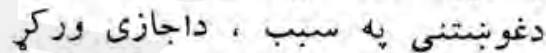

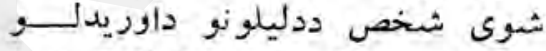

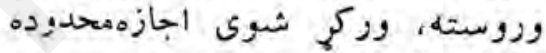

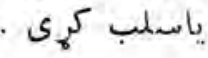

$$
\text { دويم جزء - حجر }
$$

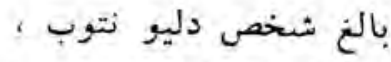

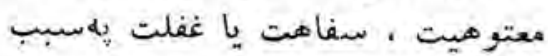
بها حجر هحكو ميرِى او ترهنه وخته

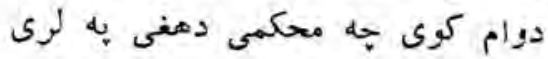

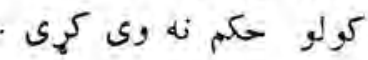

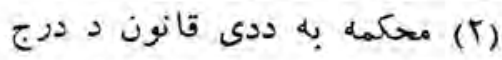
ثبوو حكمونو سره سم دمغه شخص

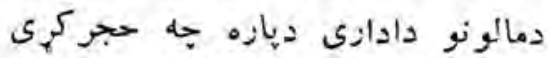
شوى دى ، قيم تاكى دوالى 
- rr.

مصارف مربوط به سر ماده برستسى

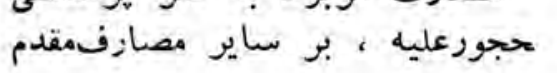
مىباشد . مجورعليه

- ماده

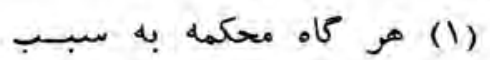

مفاهت ياغفلت شخصى را در ادازه

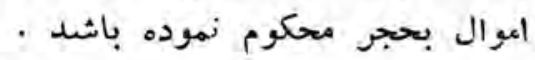

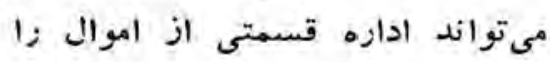

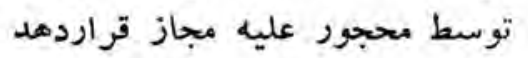

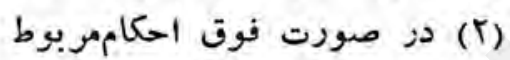

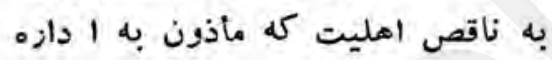
اموال باشد ، تطبين ميكردد .

\section{ماده - rrr}

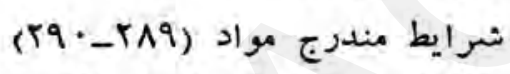
اين قانون دز مورد قيم اعتبار داشته

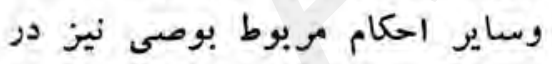

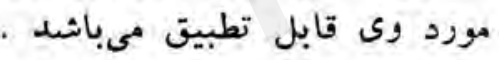

$$
\begin{aligned}
& \text { جزء جهاد - غايب ومفقود } \\
& \text { ماده }
\end{aligned}
$$

هر كاه شخص واجد اهليتقانونى مدت يكسال و يابيشتر ازآن غايب بوده ودز الثر آن مصالح وى مـتأئر

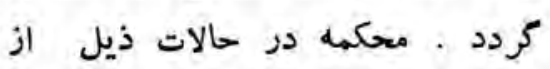
طرف او وكيل تعيين مينمايد :

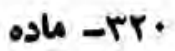

دحجر كرى شوى ديالنى مصروفونه

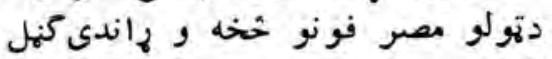
كين.

ו וTr-

(1)

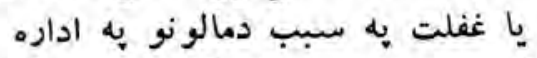

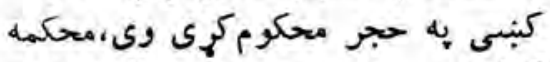

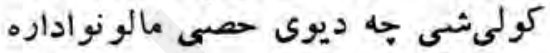

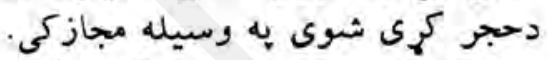

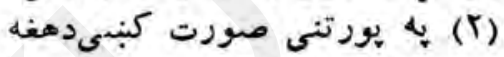
اهليت نقصان لرونكى يورى مربور

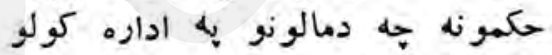

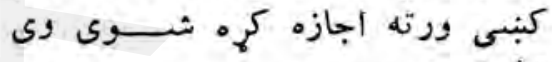

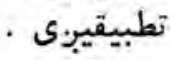

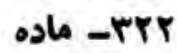

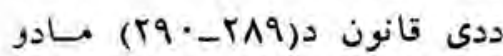

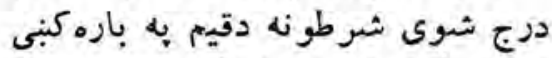

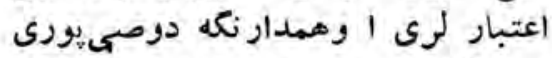

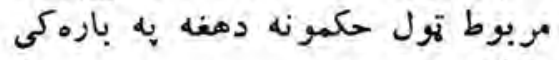

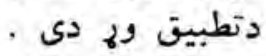
خلودمجزء - غايب اوورك شئي (

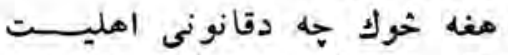

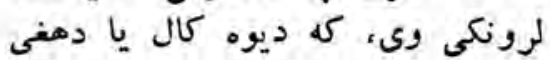

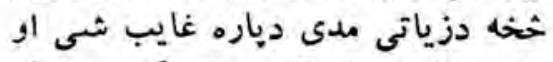

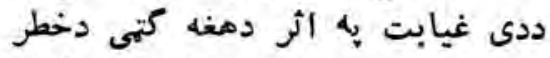

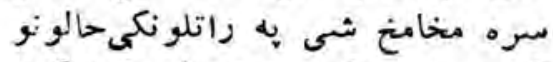

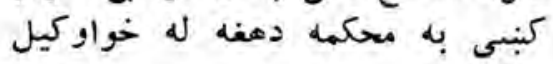
: 


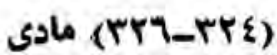

دوهم فصل - اشخاص

1- در صورتيكه مفقود الاثربوده

حيات ورفات وى معلوم نباشد . T- دز صو ر تيكه هحل سكو نت

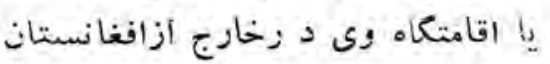

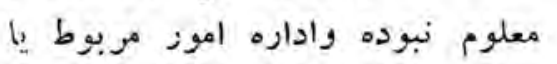

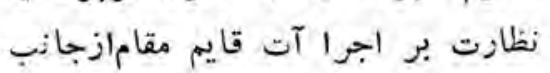

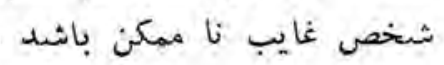

\section{ماده}

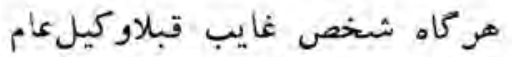

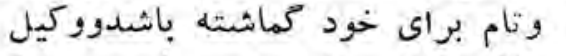

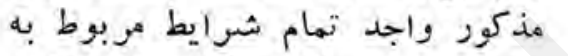

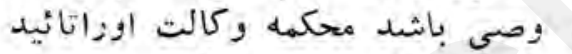

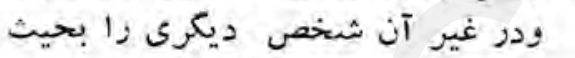

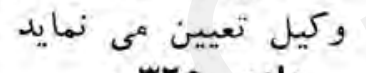
- ماده

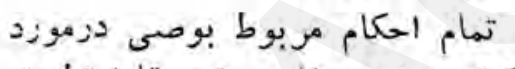

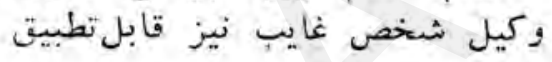

$$
\text { - rer }
$$

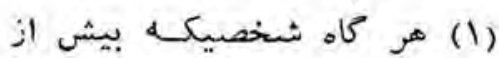
جارسال مفقود كرديده وغالباً هلاك

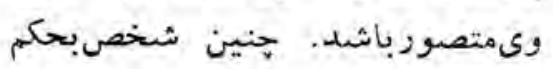
محكمهل با صلا حيت متوفىشيناخته

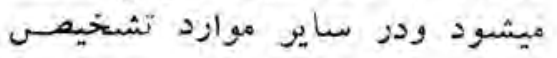

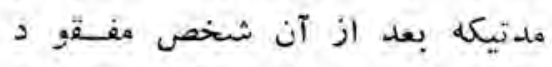

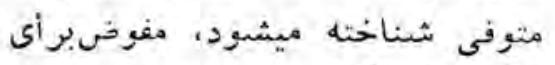

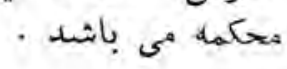

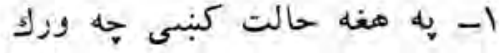

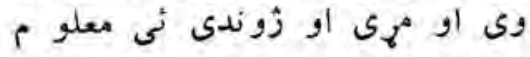
نه وي داف

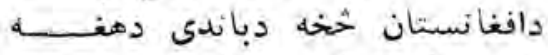

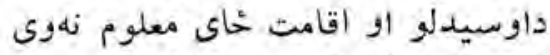

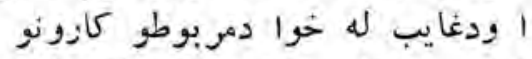

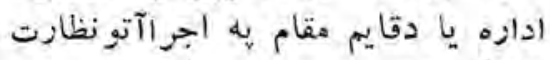
- نامaكن ع

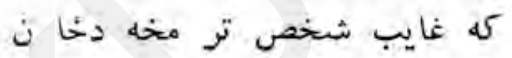

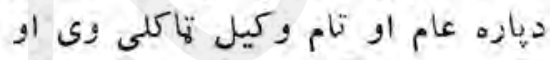

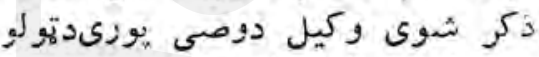

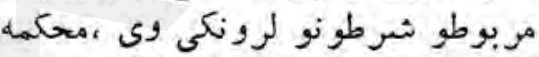

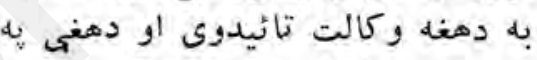

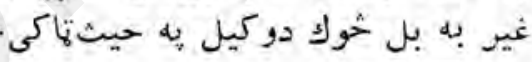

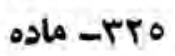
دوصى يورى تول ميربوط حكمونه

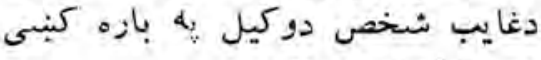

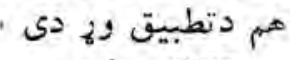
דrr

(1)

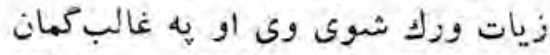

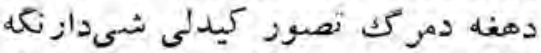

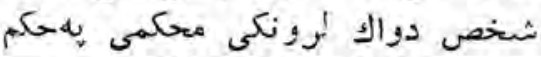

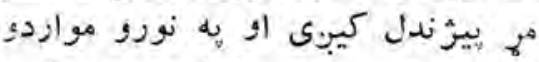

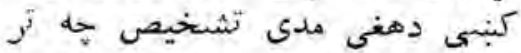

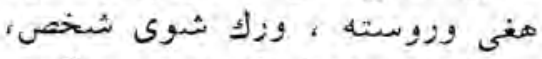

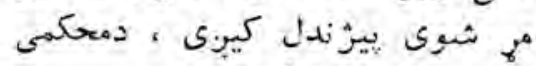

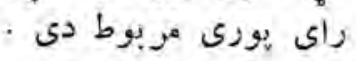




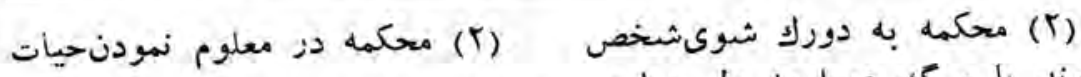

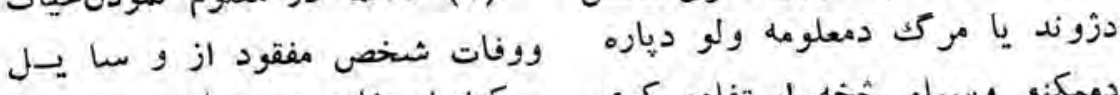

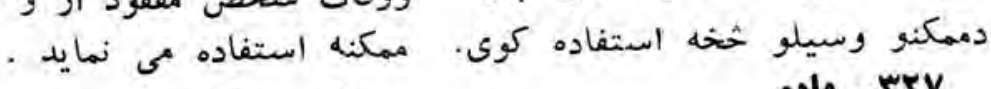
- rrV

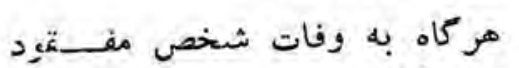

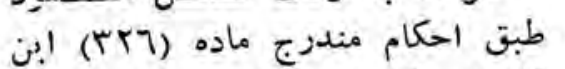

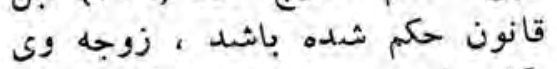

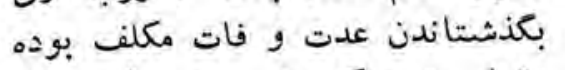
وتمام مترو كه وى بين ورثن 1 يكن فين

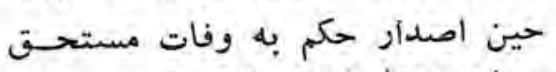

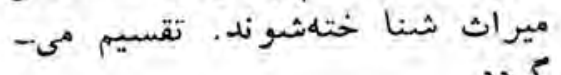

\section{ماده}

حالت غياب وقتى ختم هى كر ده كه اسباب موجبه آن از بين رفتيد وياشخص غايب وفات نمايديااينكه،

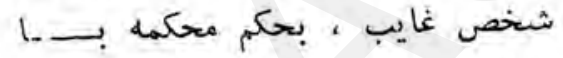

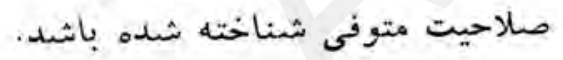

$$
\begin{aligned}
& \text { جزء ينجم - مساعدت قضائى } \\
& \text { ماده }
\end{aligned}
$$

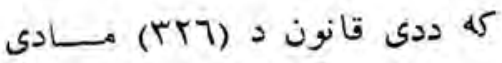
ددزج شوى حكمونو سره سم سم دورك

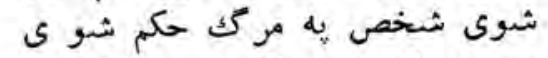

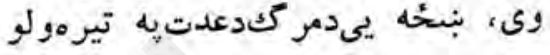

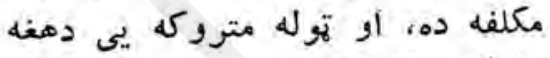

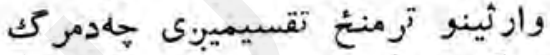

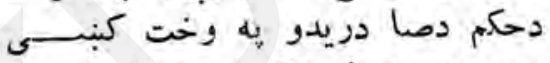

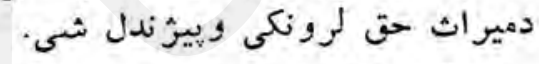
A

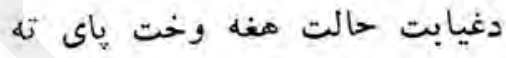

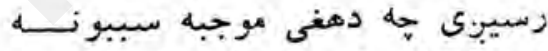

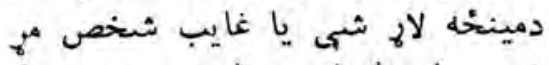

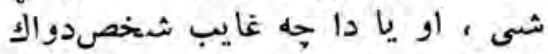

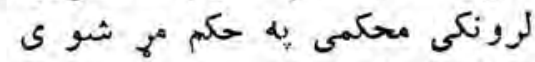

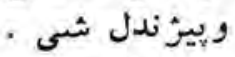

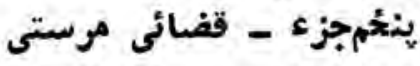

$$
\begin{aligned}
& \text { 9זr_ סוدם }
\end{aligned}
$$

هر كاهشخص مروركنكياكوروكرياكور وكنك بوده ونه تواند اراده خودرا طور صحيع ابراز نمايد ، يحكمـــ

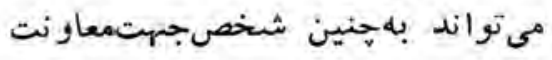
درتصرفات مندزج ماده (ع-r) اين قانون مساءعـد قضائسى تعيين نمايد كه خوك كوين او كنك ماره ، يا يوند

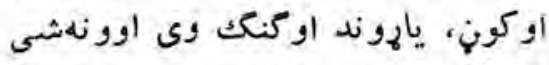

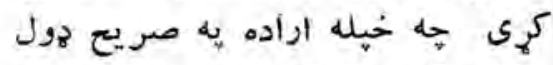

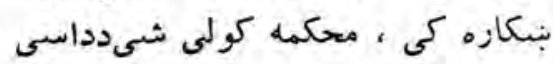

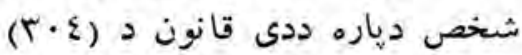
هادى ددزج شوو تصرفونودمرستى قدون

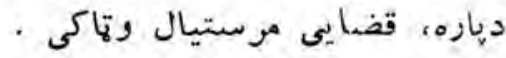


- rr. مادم

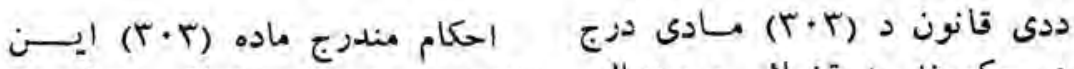

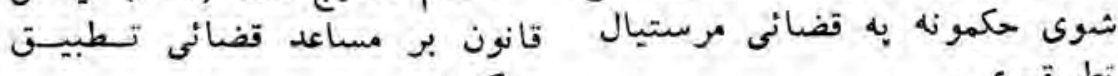

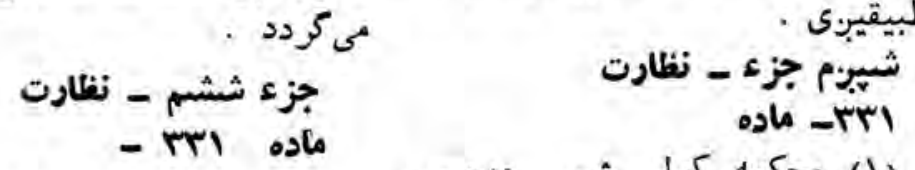

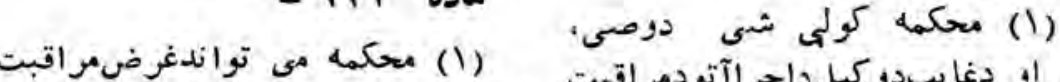

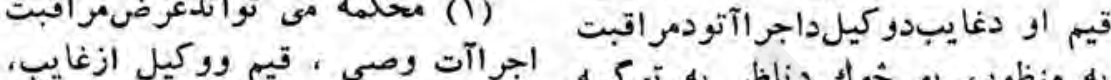

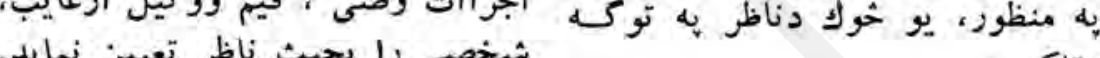

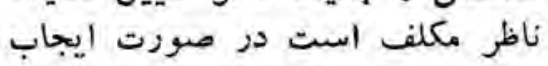

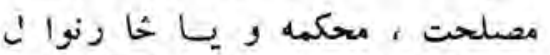
هربوط را ازجريان امورمطلعكرداند.

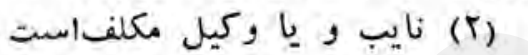
تابه استيضاح ناظر در مورد اداره

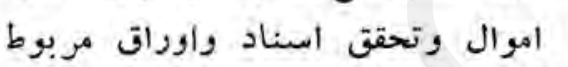

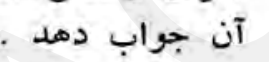

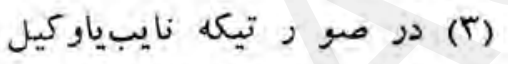

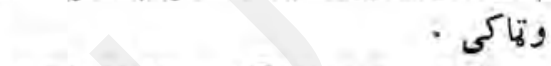
إبه هغه صورت كني

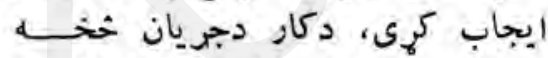

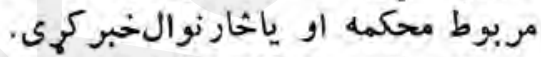

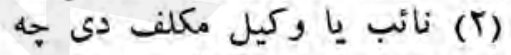

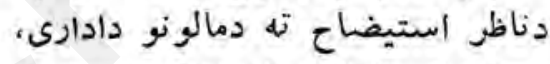

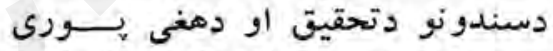

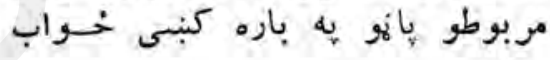

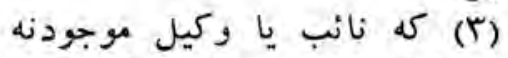

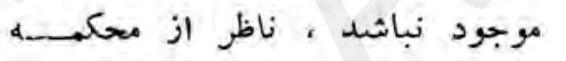

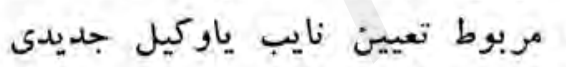
را تقاضا مى نهايد.

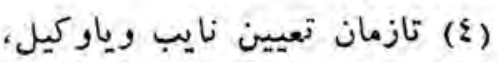

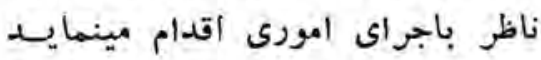
كه درتاخير آن ضرر متصور امورى باشد. ماده

در هورد تعيبين ، عزل ، استعفل،

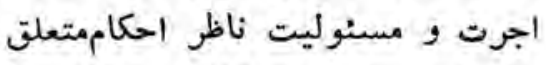

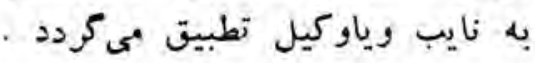

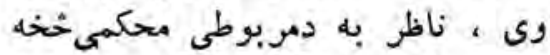
دنوى نائب يا وكيل دئاكلو غوبنيتها (ع) دنانب يا وكيل دئاكلودنيتهى يورى به ناظر دداسيى كارونو اجرئ داء

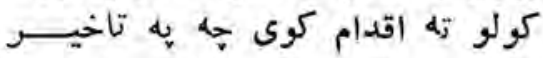

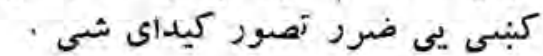

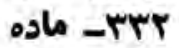

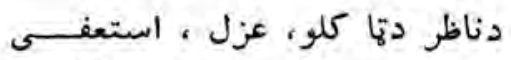

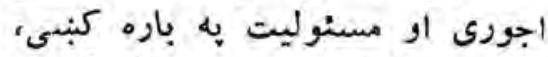
دنائب ياوكيل اوبورى مربوط حكمونه 


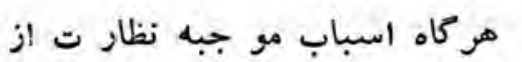

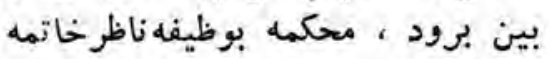

$$
\text { ميدهد . مين }
$$

$$
\begin{aligned}
& \text { جزء هفتم - مويدات } \\
& \text { ماده }
\end{aligned}
$$

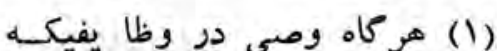

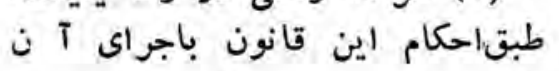

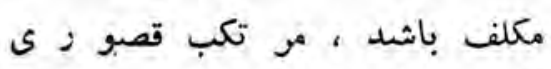

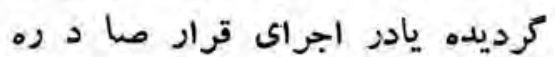

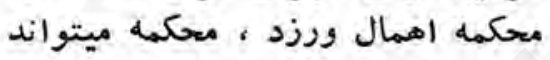

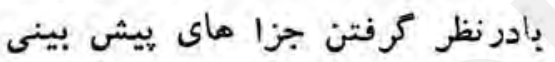

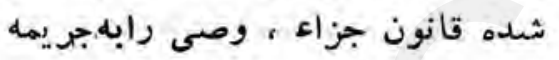

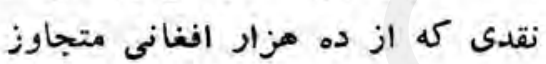

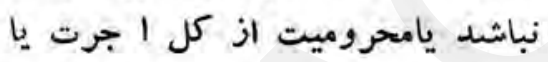
قسمتى از آن وعزل يابيكى از آنها آنها محكوم نمايد آن

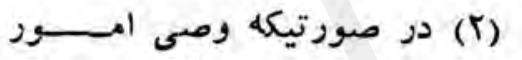
مستلزم مجازات فوق را بدوناينكه شخص ناقص اهليت متضرد كردد، جبران يا اعذار مقنعهنزدمحكمهإزائه

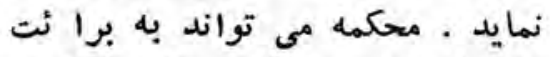

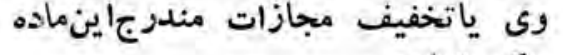
حكم نمايد . واتخفيد

\section{- rro}

كه دنظارت موجبه سببونهادمينخه

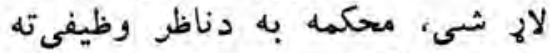

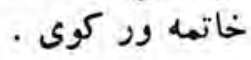

$$
\text { ع اوسم جزء - ماده - جزاكانى }
$$

(1)

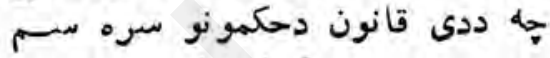

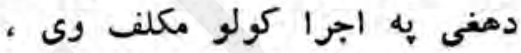

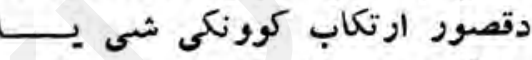

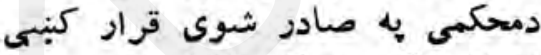

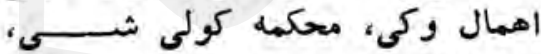

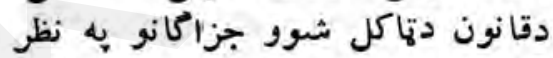

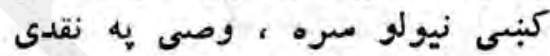

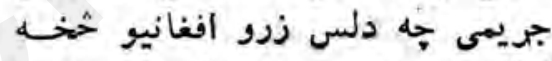

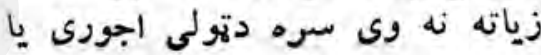

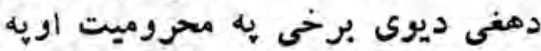

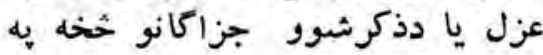
•يوى محكوم كز

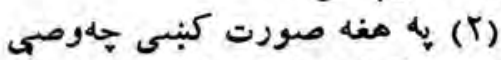

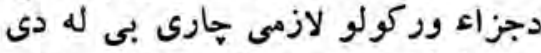

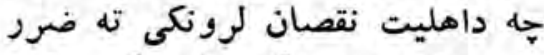

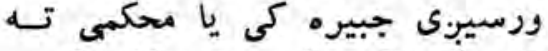

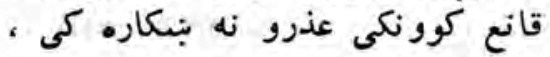

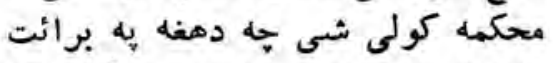

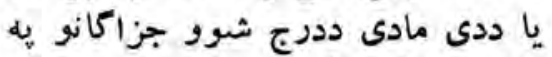
تخفيف حكم وكى مادى دورج O

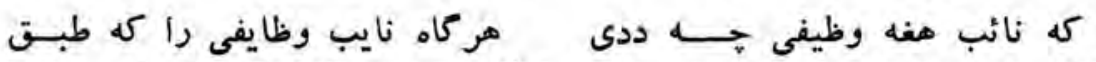

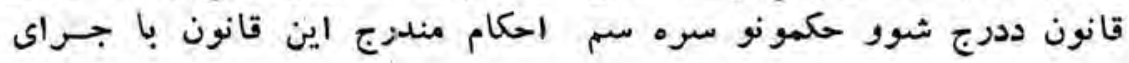


دهغى هيه اجراء كولو مكلف دى اخلال آن مكلف مىياشد اخلال نهوده وبه

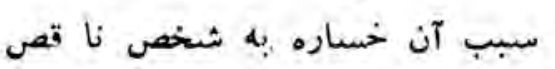

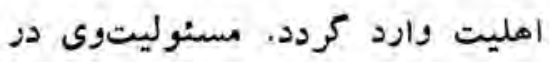
جبران خساره تابع حدود مسنوليت

$$
\text { مكيل باجرت مىباثد . }
$$

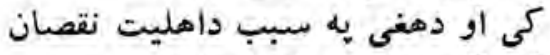

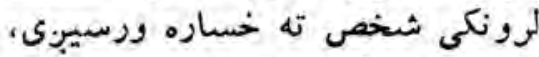

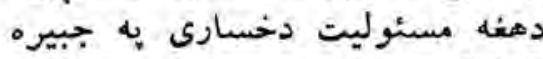
كولوكبنى، به اجوره بانديت دونى دنيول

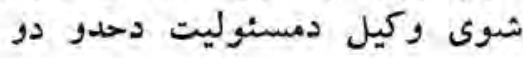
تابع دى .

$$
\text { רזr- ماده }
$$

احكام مندرج مواد (rro_rre) اين قانون بر قيم ، مساعدقضانى، مناء وكيل از غايب ووصى خاص ورصى موقت تطبيت مىكردد قسمث دوم مي اشخاص حكمى مبحثاول - احكام عموهى - ماده

شخص مكمىشخصيتمعنويست كهواجد ا مليت حقوقى بوده وبنابر اهداف معين بشكلموسسس، شركت

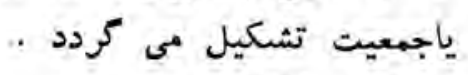
- ماده

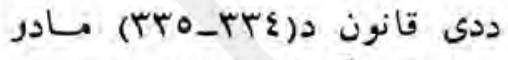

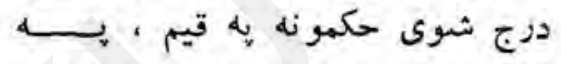

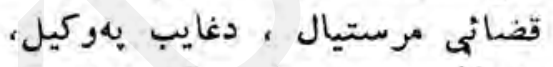

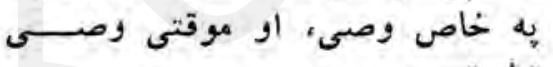
- تطبيقيبى

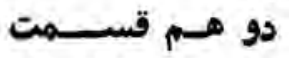

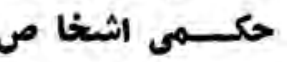

$$
\begin{aligned}
& \text { لمحي مبحث - عمومى حكمونه }
\end{aligned}
$$

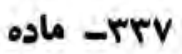

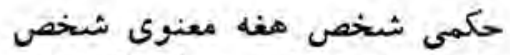

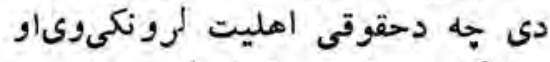

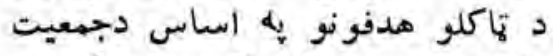

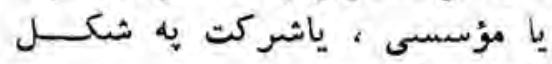

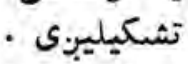

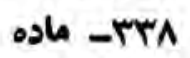

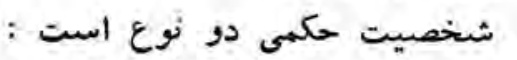

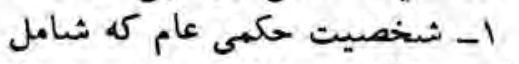
دولت ، ارِكان ، ادارات فرعى يــات

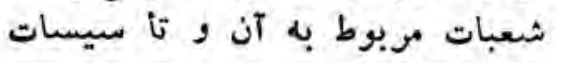
عامه ميباشبد r- شخصيت حكمى خاص كـــه حكمى شخصيت هيه دوه نوعل ماده

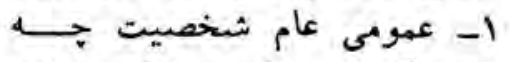

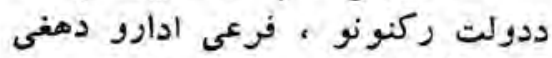

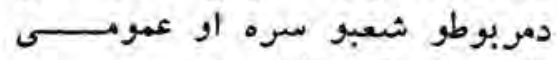

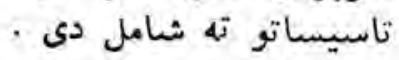

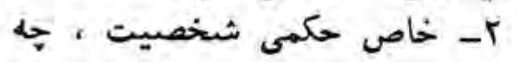


ناشسى از اراده افراد خصوصىبوده

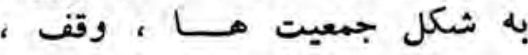

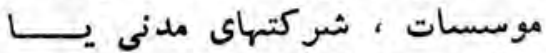

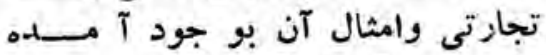

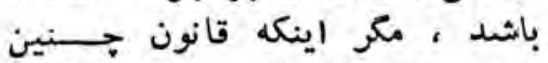
شخصيت هارا عام قرار داده باشيد.

$$
\text { ماده }
$$

مجموع اشخاصيكه واجد شرابط وعناصر لازمه يك شخصيت حسكمى واجيك

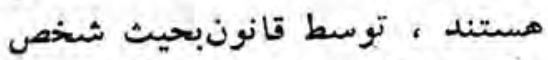

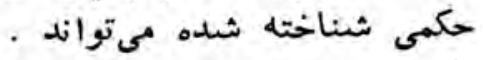

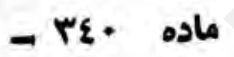

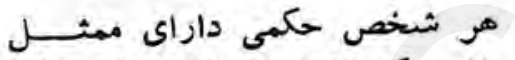

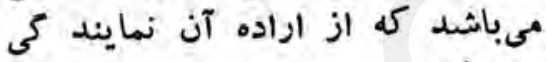

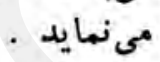

\section{- ماده}

شخص حكمى داراى جميع حقو-

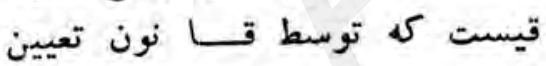
كرديده . مكر حقوقيكه منحصر به

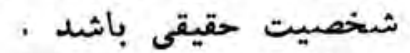

$$
\text { ماده }
$$

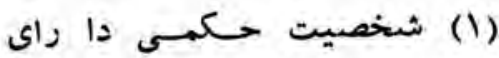
خصوصيات آتى مى باشد :

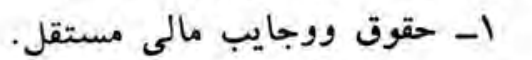

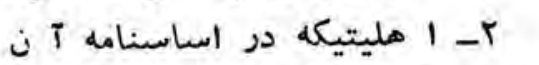
تحديد كرديده وقانون آنرا مجهاز دانسته باشد كرديل
دخصوصى افرادو دارأدى خخه بييدا

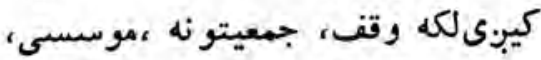

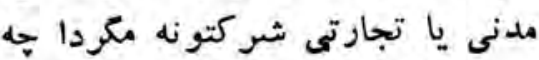

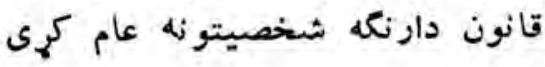
وى

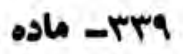

دهغه اشخاصو مجموعه جه ديه ديو

حكمى شخصيت دشرطونو اوعناصرو

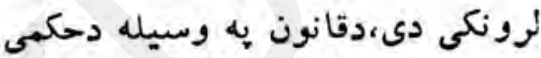

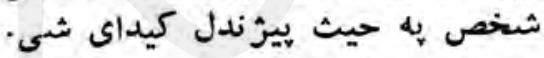
• عr- ماده

هرحكمى شخص ديو ممثللرونكى وى جه دمغه دارادى نمايندكى كوى.

\section{اعr- ماده}

حقيقى شخصيت دتولو هغوحقوقو

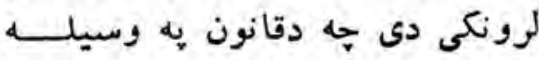

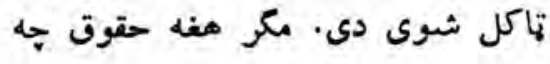
دحقيقى شخصيت يورى منحصروى. rEr (1) حكمى شخصيت دراتلو نكسو

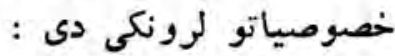
ا- خانكيرمالى حقوقاووجايب.

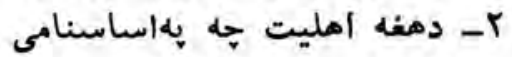
كنبى تحديد شوى اوقانونيى مجاز كنلى وى - كلينى 
r- حق اقامه و دفع دعوى - مان.

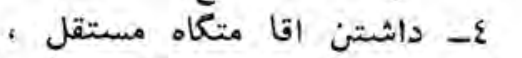
وآن عبارت از هحليست كه در آنجا

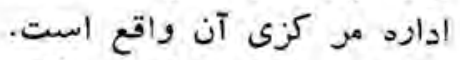

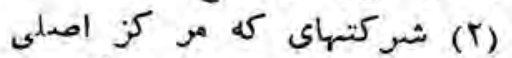

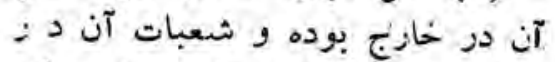

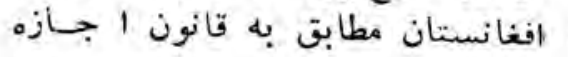

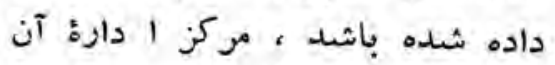

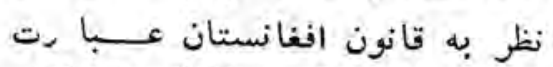

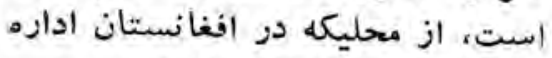

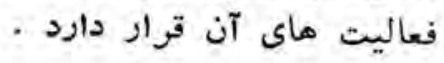

$$
\begin{aligned}
& \text { مبحث دوم - وقف } \\
& \text { ماده }
\end{aligned}
$$

وقف عبارت است ازه حبس

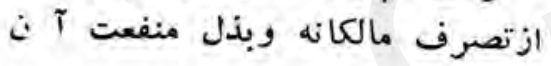

$$
\text { بامور خيريه . مادوف ماله }
$$

\section{- ماده}

وقف ، ماده عارنى شخصيت حكــى است كم توسط اساسناهله تئبيت مى مرد . ماده

\section{ماده}

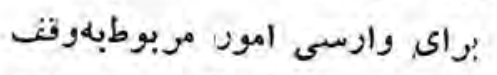
اداره دولتى بنام اوقاف وجود وازيد

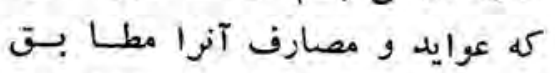

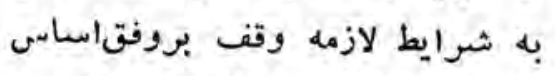

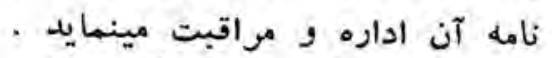

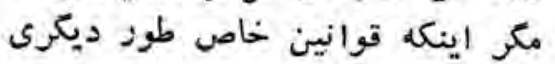
حكم كرده باشهد . مواند

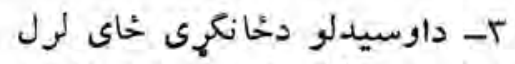

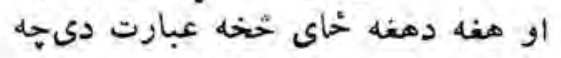

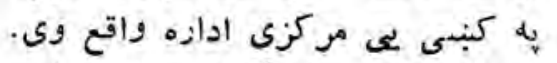

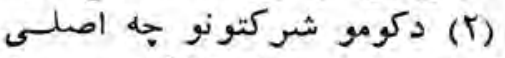

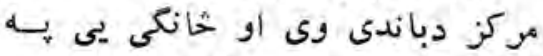

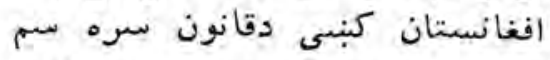

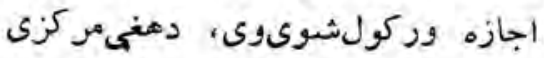

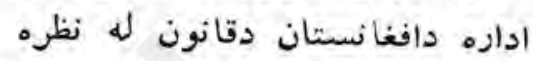

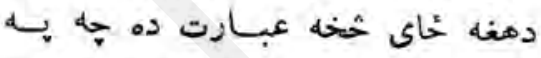

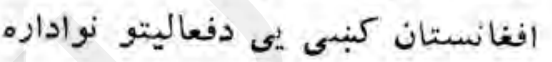
موجوده ده . معان

$$
\text { دوعهم مبحث - وقه ماده }
$$

وقف عبارت دى دمالكانه تصرف

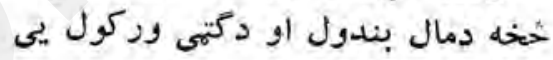
دى دخير كارونو ته ته دول

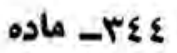

وقف ، حكمى شخصيـــى او داساسنامى به وسيله تثبيتيبى 年

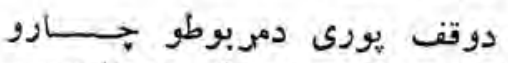

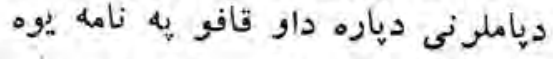

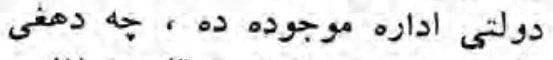

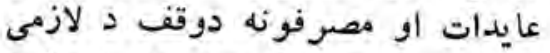

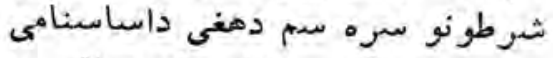

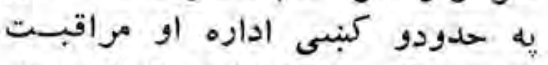

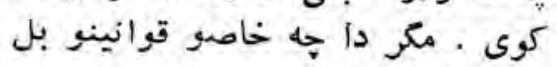

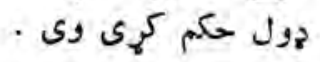




\section{- ماده}

وقف داراى حقوق ووجايب مالى

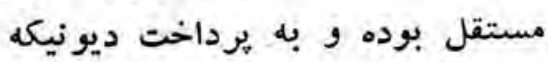

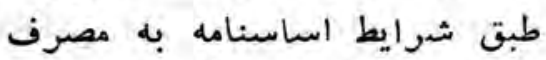

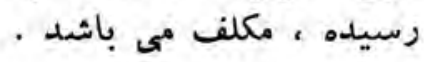

$$
\text { - rEV }
$$

صحت وقف، رجوع ازآن وهرگونه

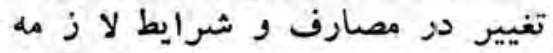

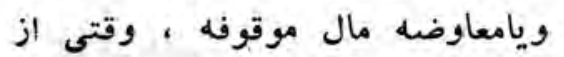

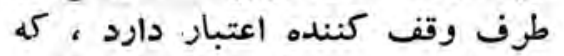
در دفاتو مربوط ثبت كرديده باشد.

$$
\text { - ماده }
$$

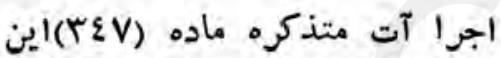
قانون در دفاتر خاصيكه دز 1 دازي ثبت اسناد باين منظور تعيين درديد

$$
\begin{aligned}
& \text { به لبت ميرسد } \\
& \text { - rEq }
\end{aligned}
$$

هر كاه نزد ثبت كننده راجع بهـه اعتبار سند وقف مانعى ظاهر كزدد، موضوع غرض انفصال واخذتصميم

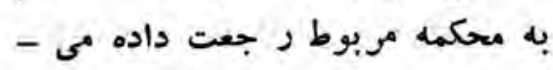

$$
\text { شود . به }
$$

$$
\text { - ro. ماده }
$$

هركاه وقف طبق احكام مسندرج

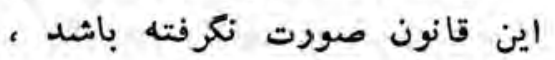

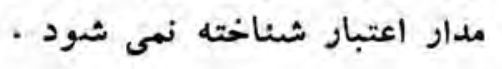

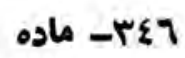

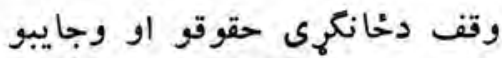

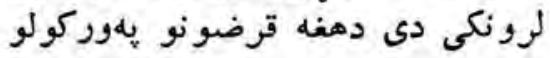

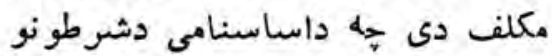

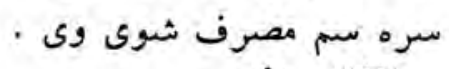
V

دوقف صحت، دهغى خخه رجوع

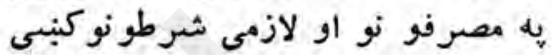
تغيير يا دوقف كمهـ شوى مومال بدلول،

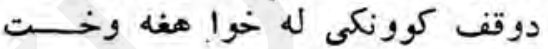

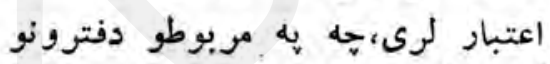
كبنى ثبت شوى وى لرى ماعه

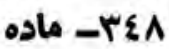

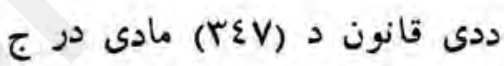

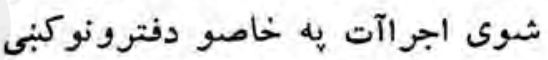

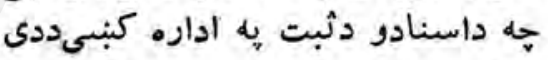

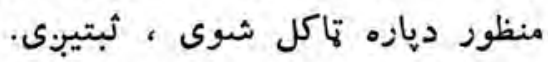
كو كه دثبت كوونكى سره دو قــف مون ماه دسند يه باره كنبى كومه مانعظاهيه

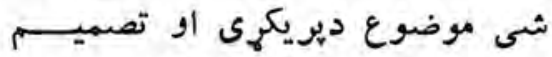
دياره مربوطى محكمى ته اسيـتو ل كيب.ى دياره

$$
\text { ( }
$$

كه وقف ددى قانون ددرج شوو

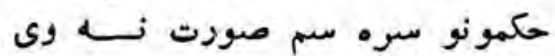

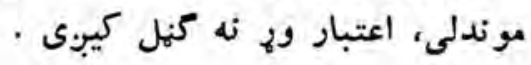




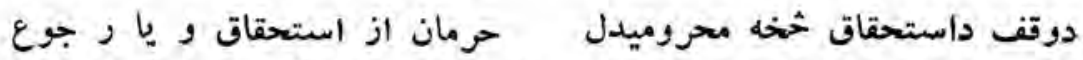

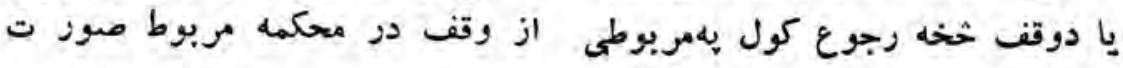

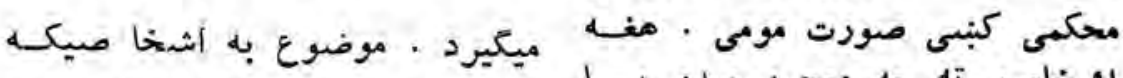

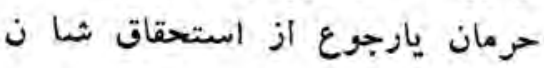
راده شده ابلاغ مىكردد ، تان دلايل

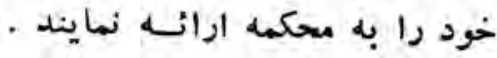

$$
\text { - ror ol }
$$

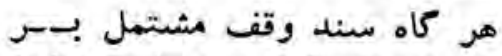

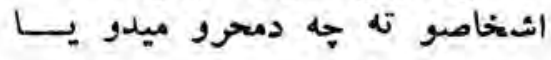

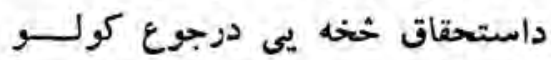

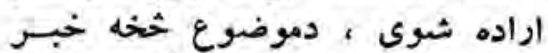

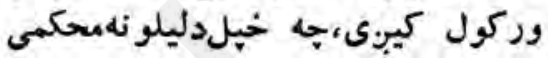

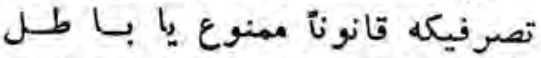

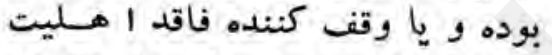

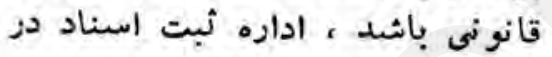

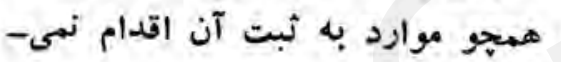

\section{ن مايد}

\section{- ror مادم}

هر كاه وقف به شرط غير صحيح

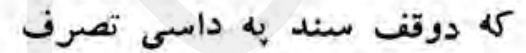

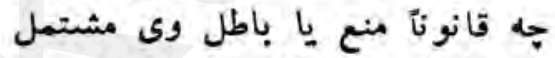

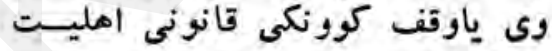
ونه لوى ، داسنادو دثبت اداره بهيه

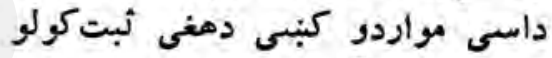
ته بنساره كي ror

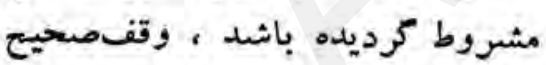

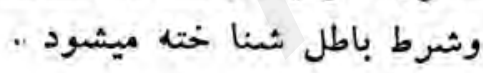
ماده

(1) وقف بطور دائسى يا مـ قود جواز دارد

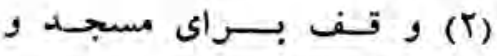

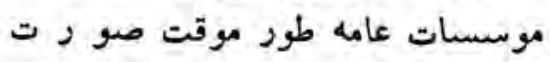
كرفته نمىتواند .

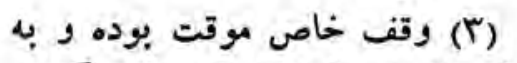

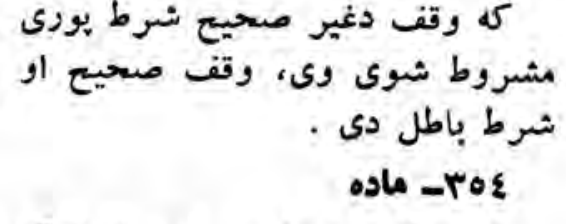
جواز (1) وقف به دايهى يا موقتى متوكه

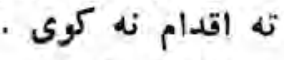
ol -ror زياده از دو طبقه اولاد وقف كوقن كنئه

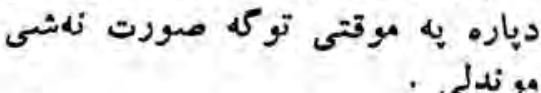

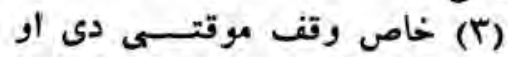
دوقف كوونكى دووه طبقر اولادى 


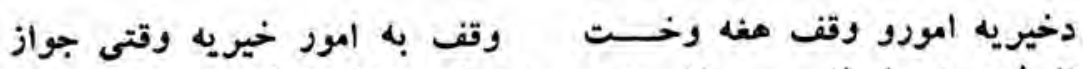

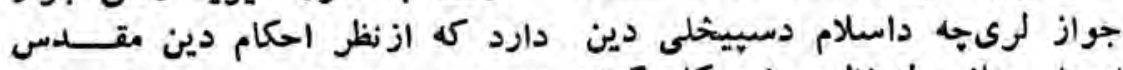

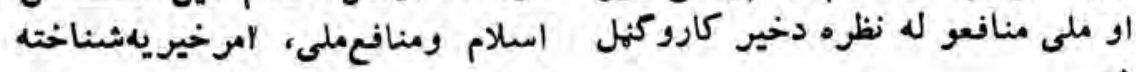

$$
\text { - ror مادم }
$$$$
\text { ols - rot }
$$

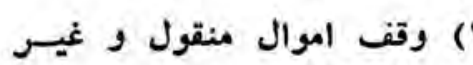

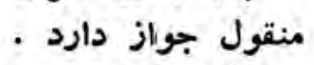

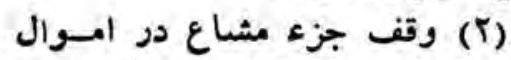

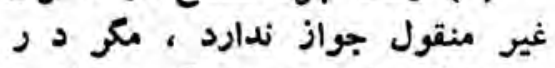
صورتيكه مفرز ومعين كرديدهباشد.

$$
\text { - ror ماده }
$$

اسهام شركتهاىكه فعاليت مجاز

$$
\begin{aligned}
& \text { دارند وقف شده مى تواند . } \\
& \text { - ros ماده }
\end{aligned}
$$

اظهارات وقف كننده در ماه مـورد

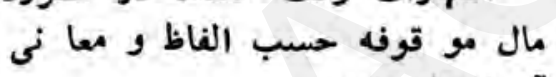

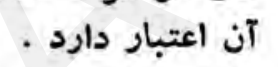

$$
\text { ماده }
$$

(1) وقف كننده نهى تواند ازتمام

ويا قسمتى از وقف عام دجوع نمايد.

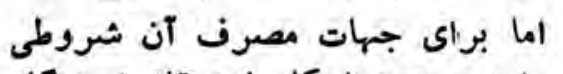
را در حدود احكام اين قانون هنكات منان

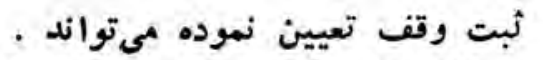

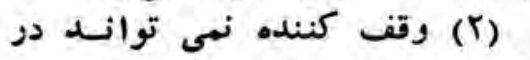

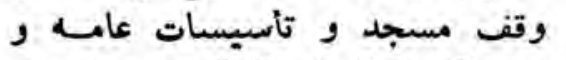

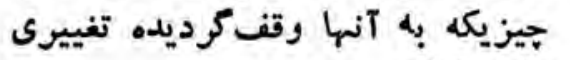

$$
\text { وارد نمايد . }
$$

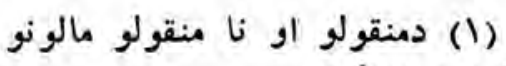

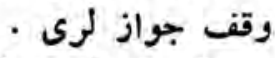

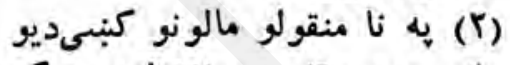

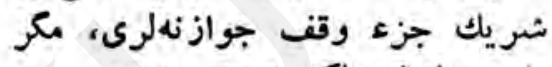

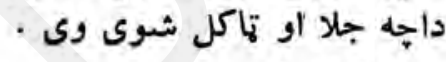

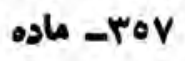

دهغو شر كتونو سهمونه جه ماده مجاز

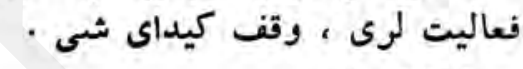

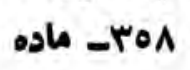

دوقف كوونكى أظهارات دو قف ماره

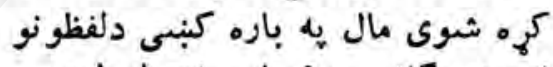

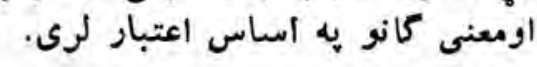

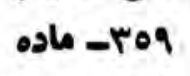

(1) وقف كوونكى نه شیى كولى

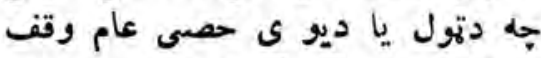

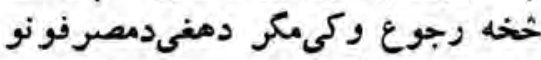

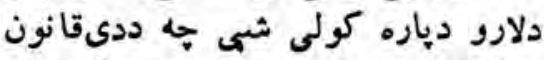

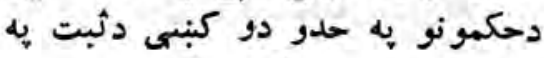

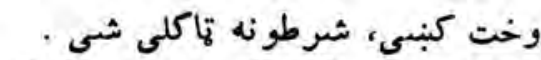

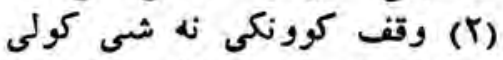
جه دجمات او عمومى تاسيساتو يه ونيه

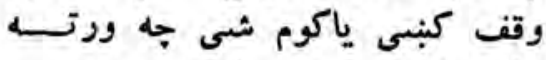

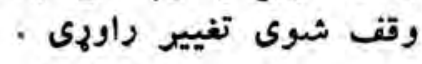


تغيير درشروط مصارف وقف عام

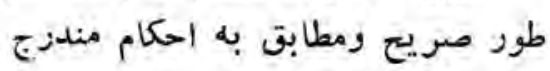
اين قانون صونت ميكيرد .

\section{ماده 1}

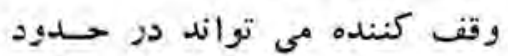
احكام اين قانون استفاده از از حقوت

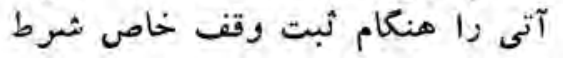
كذارد :

$$
\begin{aligned}
& \text { 1- إعطاء و حرمان : }
\end{aligned}
$$

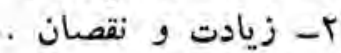

$$
\begin{aligned}
& \text { r } \\
& \text { ع- ميـا دله } \\
& \text { - rar }
\end{aligned}
$$

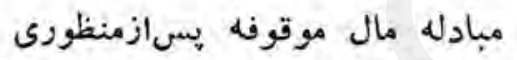

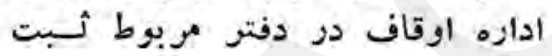

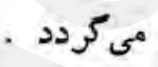$$
\text { - مأدor }
$$

اقرار وقف كنثده ياغير واه جاهن به نسب شخص، در حاليكه قرائسن

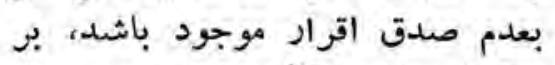

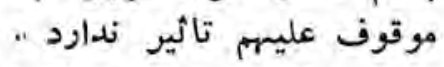

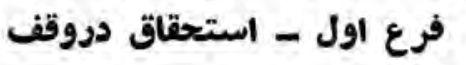
ماده

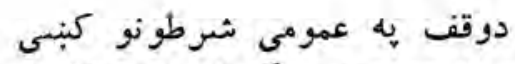

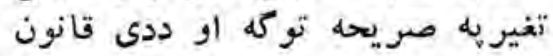
ددزج شوو حكمونو سره سمرصو اون دوى قانون

$$
\text { ורזי ماده }
$$

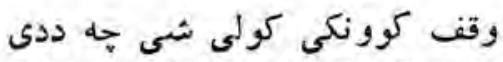

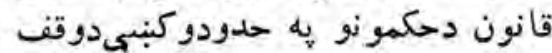

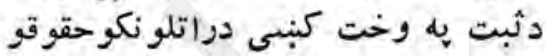
خخه استفاده شرط أنى

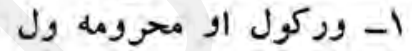
r- زياتوالى أو نقول - ع ع- عدل rרזה ماده

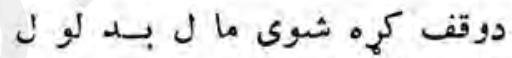

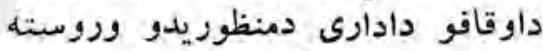

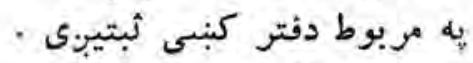
זרז_ ماده

دوقف كوونكى اقرار يا دبل جاءه

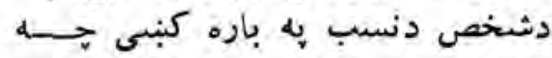

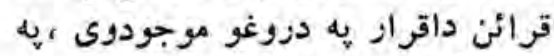

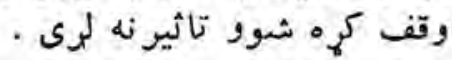

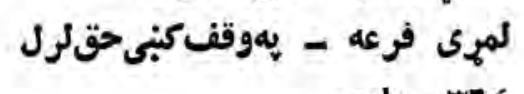

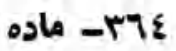

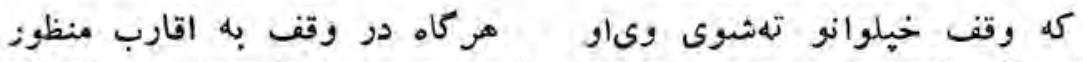

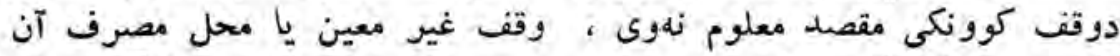

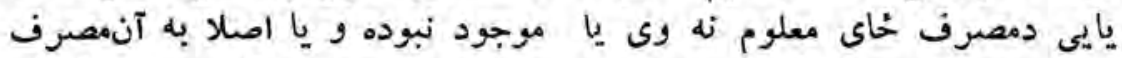

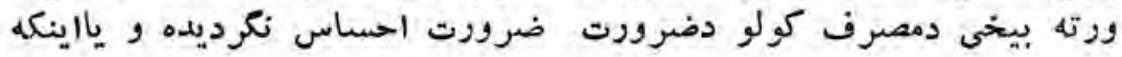

$$
(1 \cdot \varepsilon)
$$


حاصلاتوقف بيشاز اندازه مصرف

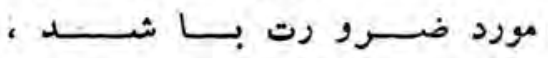

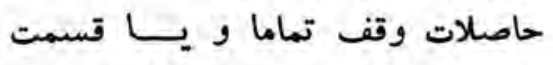
باقيمانده آن به اجازه محكمهلبهاولاد

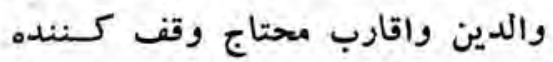

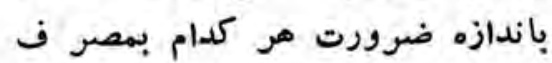

\section{- Mo}

ازئ (1) وقف كننده نمى تواند بيثن

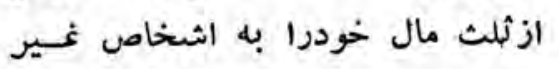

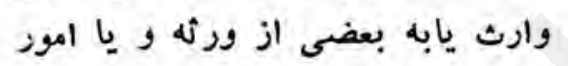
خيريه وقف نمايد .

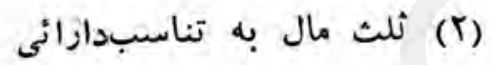

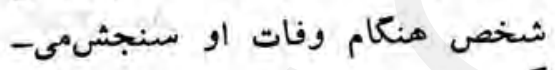
- ماده مال (1) وقف كننده مىتواند جميع

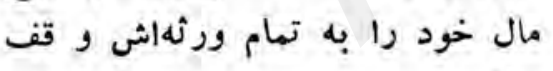
نمايد . نمال وارث (T) اكر وقف كنيده حين وفات

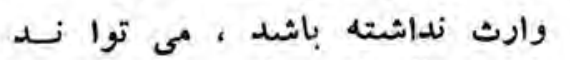

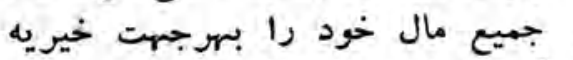

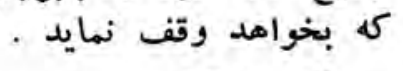
- Ml

احساس نه وى يا دا جها دوقــف حاصلات دضرورت وه مصرف خخه زيات وى، دوقف تول حاصـلا ت يا دهغى ياتى برخه دمحكمى لهيه اجـازه دوالدينو ×ه اولاد او دوقف كوونكى برى

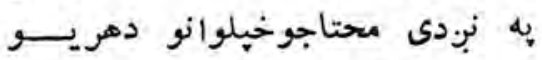

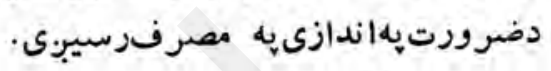

\section{סרז- ماده}

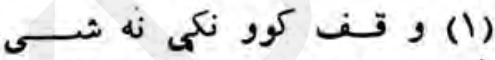

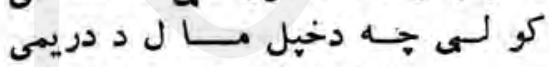

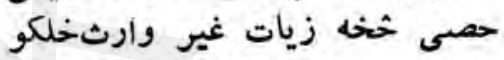
ته يا خينى وارثينو ته يا دخير كارونو

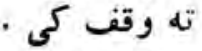
(T) (Th)

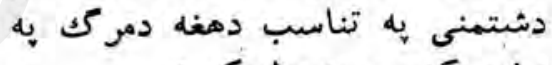

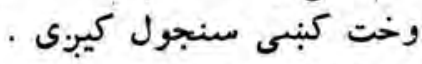

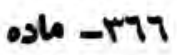

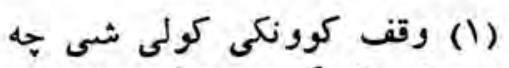
خيل تول مال كردو وارثينو تهوقي

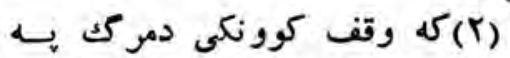

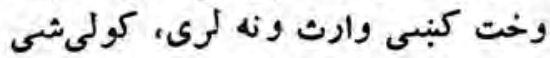

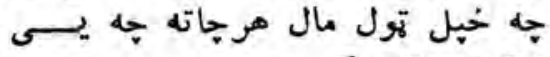
غوأهى وقف كئ تول

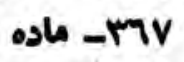

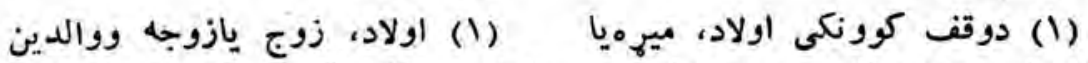

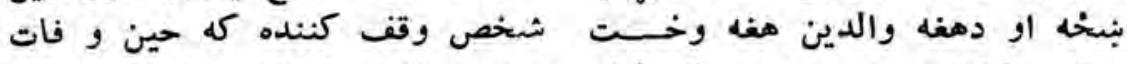

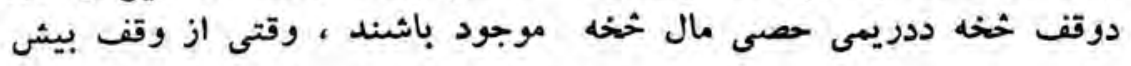




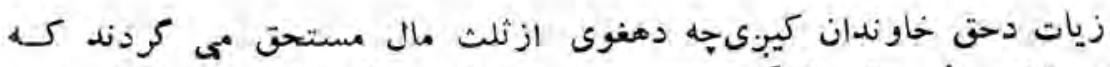

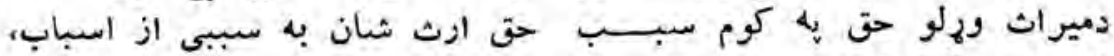

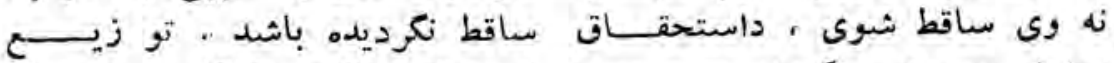

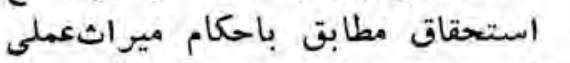

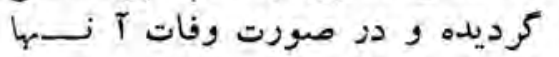

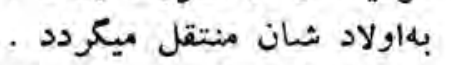

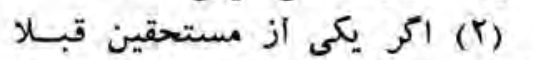

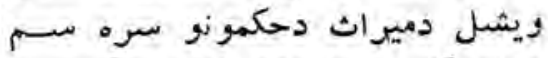

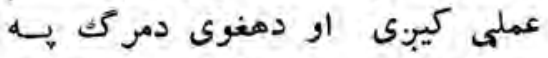

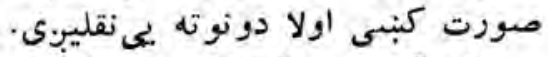

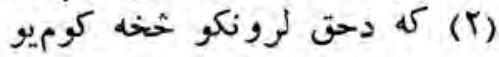

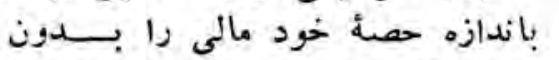

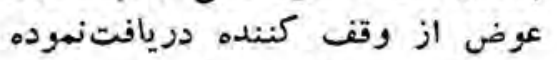

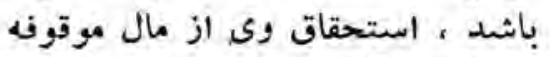

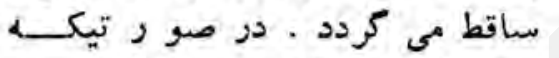
كمتر از استحقاقخود دريافتنمبرده

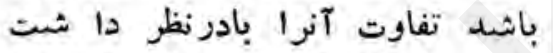

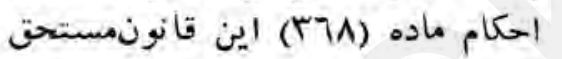
مي مردم - ماده

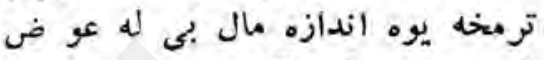

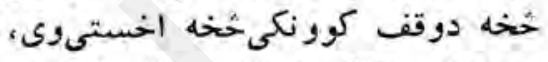

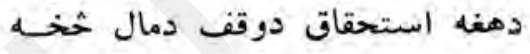

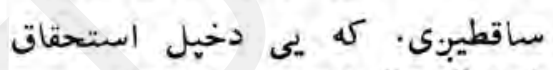

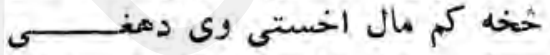

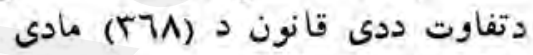

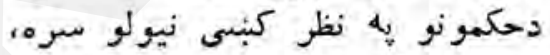
مستحق كيب.ى גרז- ماده

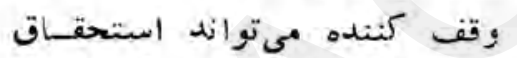

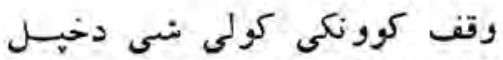

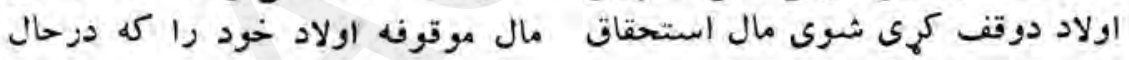

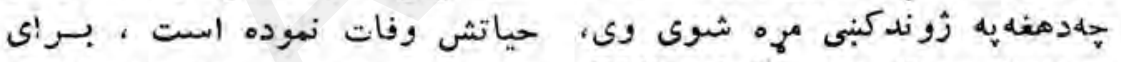

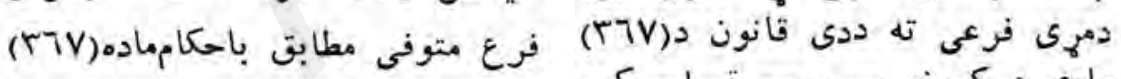

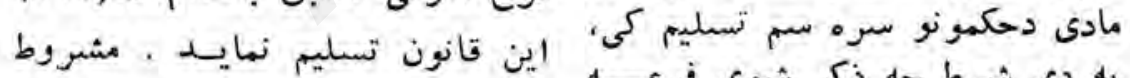

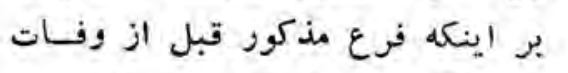

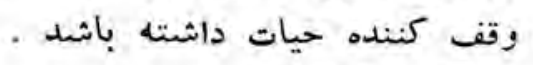

ماده

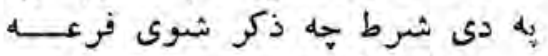

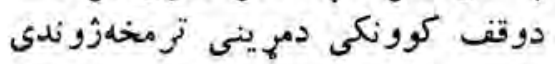
وى .

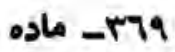

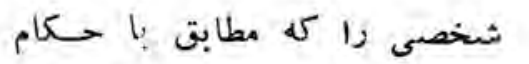

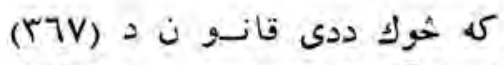

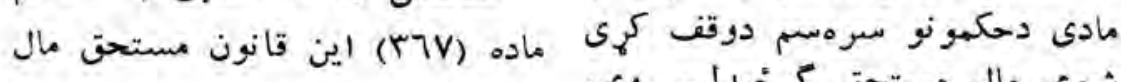

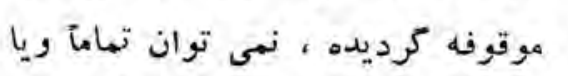

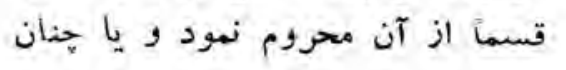

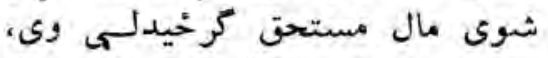

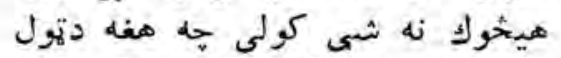

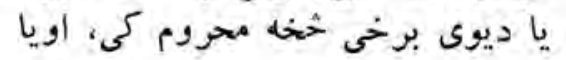




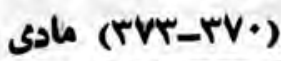

دوم ققمتـ حكمى اشتخاص

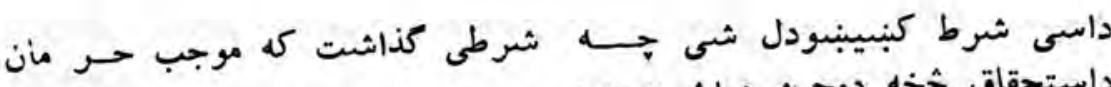

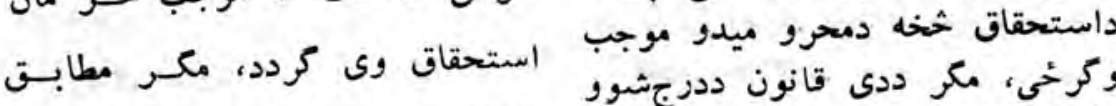

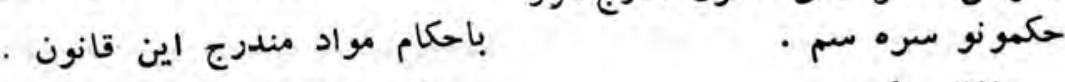

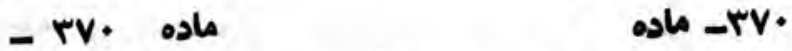

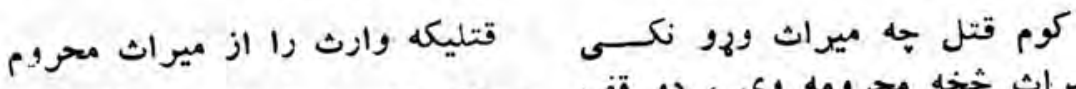

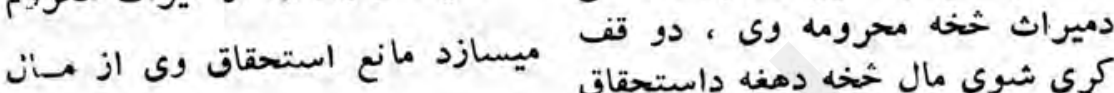

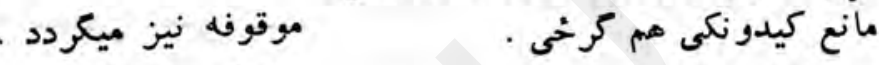

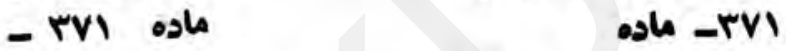

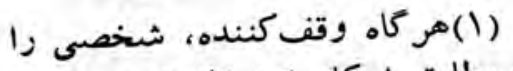

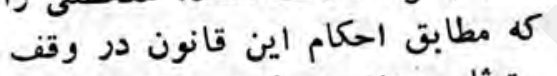

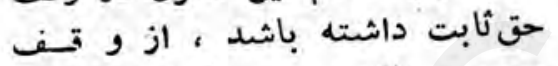

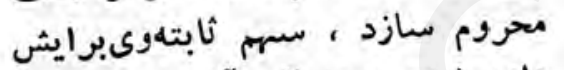

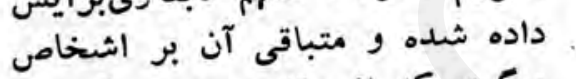

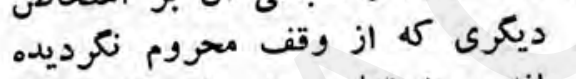

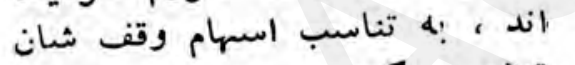

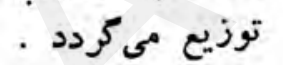

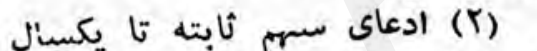

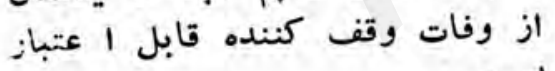

\section{- rVr}

تنازل موقوف عليه از استحقاق

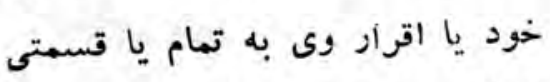

$$
\text { از آن براى غير جواز ندارد . }
$$

$$
\text { - rvr }
$$

(1)

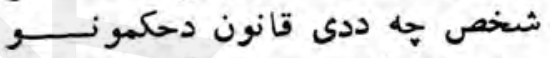

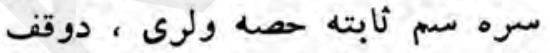

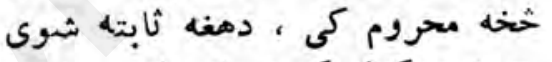

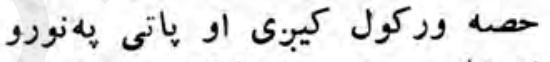

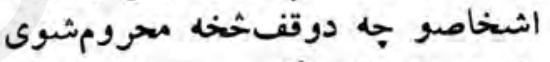

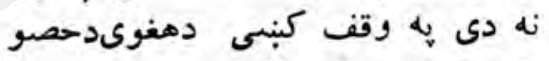

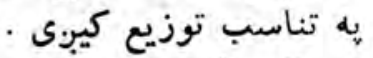

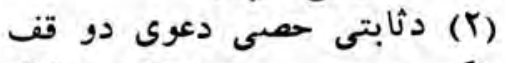

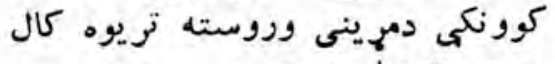

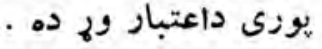

\section{نو}

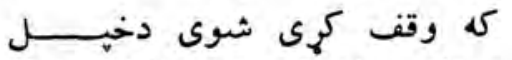

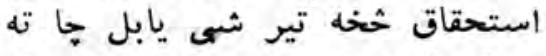

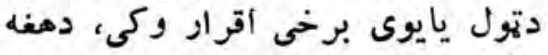

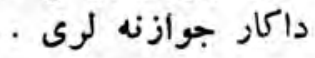
كاد

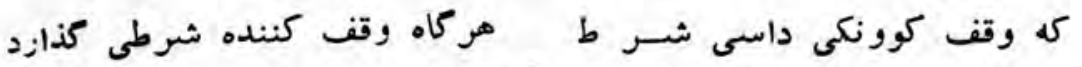

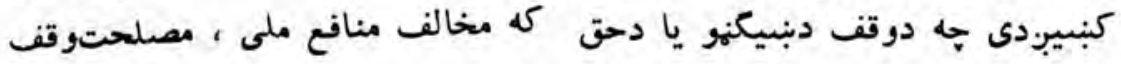




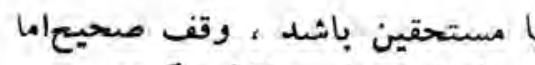

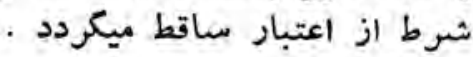
ماده HVE
لرونكو دبّبيكنو مخالف وى.داعتبار وزئه دى . 促_rVE

منزليكه به مقصد سكونت وقف ونف

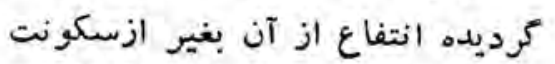

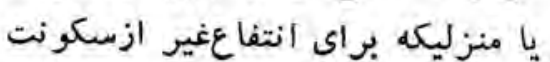
وقف كرديده ، سكونت در آن مجاز

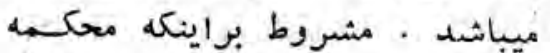
بخلافآن قرار صادر نكرده باشد.

\section{- rVo ماده}

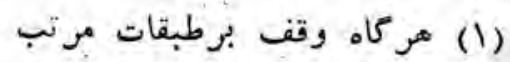

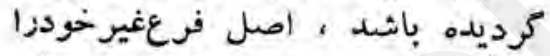

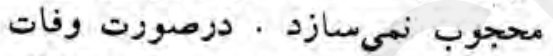

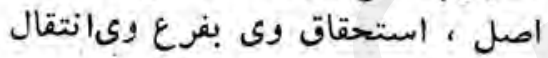
مي منايد، المبل

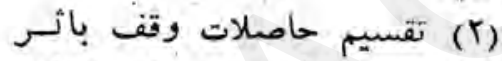
ازبين رفتن يكطبقه تغيير نماتى نهايد.

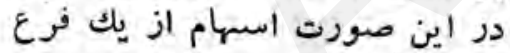

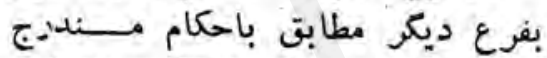
فقره اول اين ماده إنتقالمى نمائ نمايد.

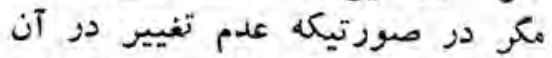

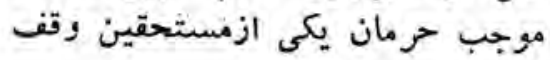

\section{- ماده}

$$
\text { كردد . }
$$

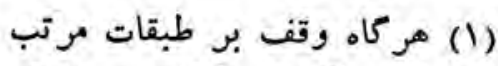

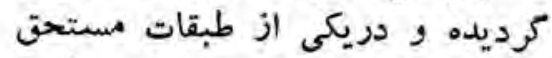

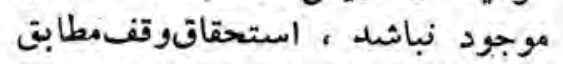

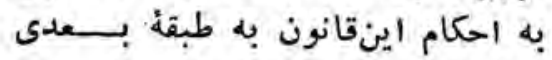

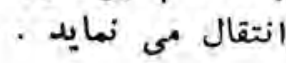

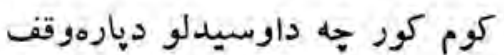

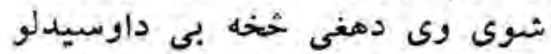

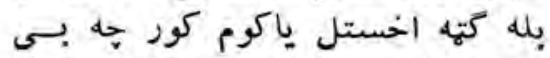
داوسيدلو بل شى ته وقف شوى اخوىى،

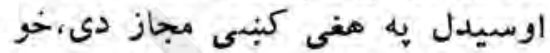

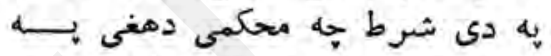

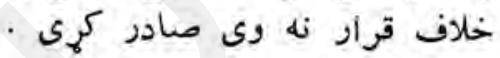
促 - rvo

وى (1)

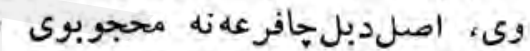

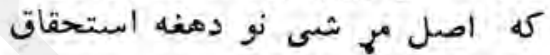

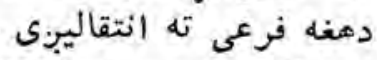

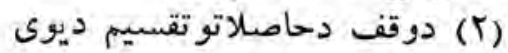

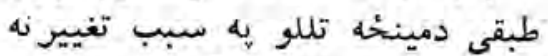

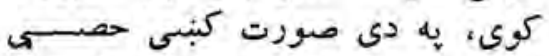

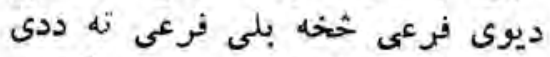

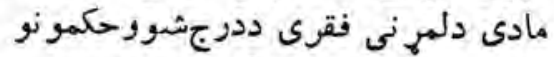

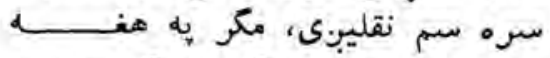

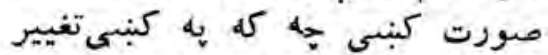

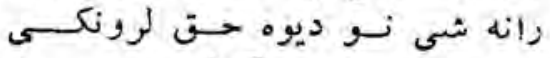

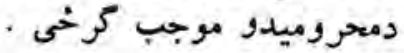
كاد وى (1)

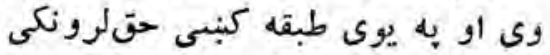

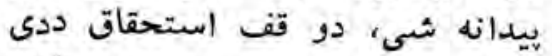

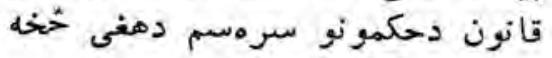

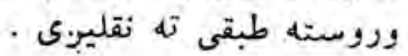




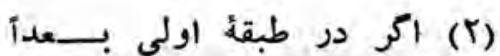

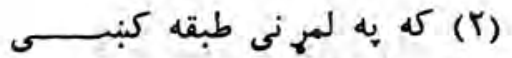

مستحق موجود شود استحقاقشان

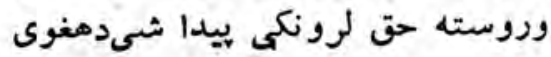

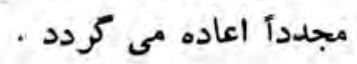
حقبير ته أعاده كيبنى لروني

$$
\begin{aligned}
& \text { فرع دوم - تقسيم وقف } \\
& \text { - rVV ماده }
\end{aligned}
$$

(1) وقف كننده بايد درسندوقف

سهم مستحقين را مفرز و معي-سن

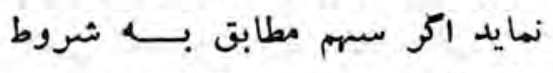

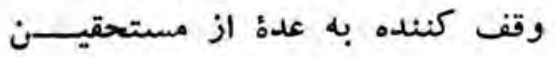
متعلق كردد ، آنها مى توانندتفريز

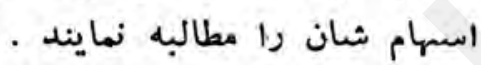

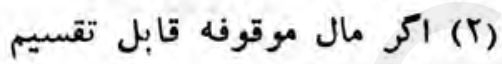

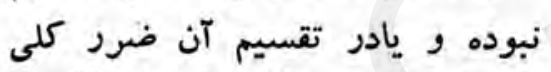
متصور باشد، مطالبه فروشوت فتسيم آنيم

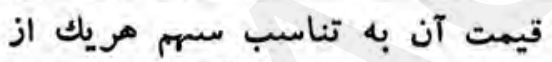

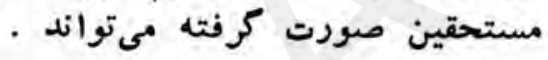
- rVA مlo

(1) وقف كوونكى بايد جه دوقيد دوقن

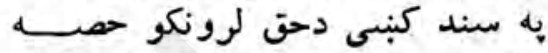

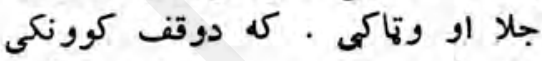

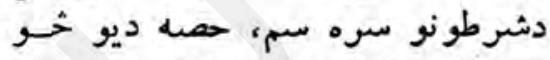

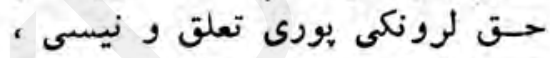

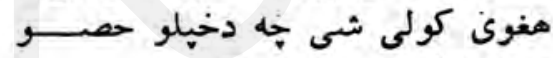

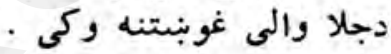

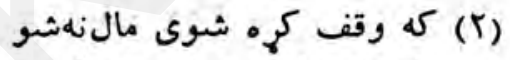

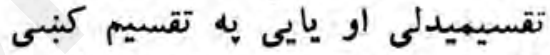

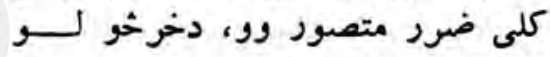

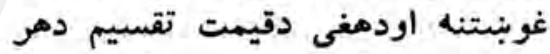

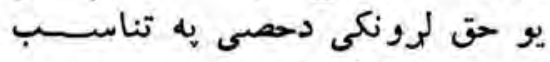

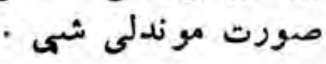

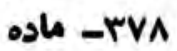
ناظر وقف عامه مى تواند تقسيم وقف وتفريز سهم مربوط بوقفعاهه • را مطالبه نمايد - rva

دعمومى وقف ناظر كولى شى جه

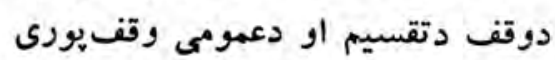

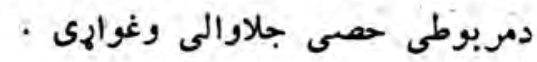
ماد -rva تقسيم وقف باثر درخواستى كه دوقف تقسيم دهغى غوبنتنى يه

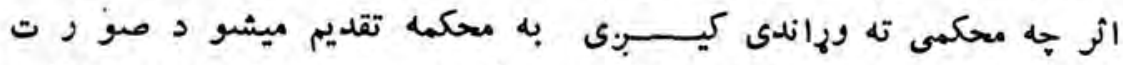

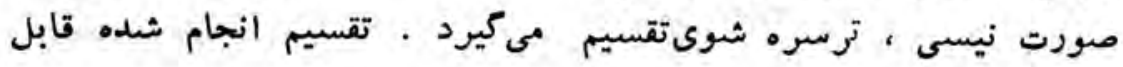
فسنخ نمى باشد .

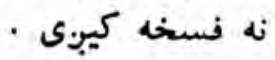




$$
\begin{aligned}
& \text { فرع سوم - اداره وقف } \\
& \text { - ra. }
\end{aligned}
$$

وقف كنندهدرسندوقف، شخصي

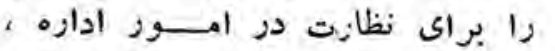

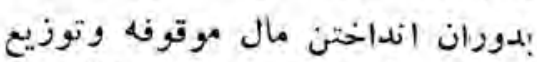

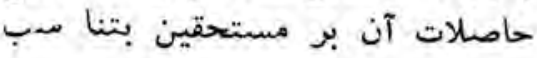

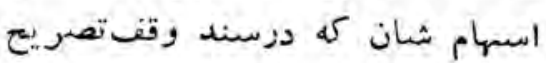

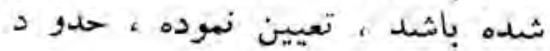
وظايف و صلا حيت وى راباشخصى باشيد

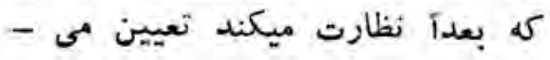

$$
\text { - ral }
$$

ناظر نمىتواند بدون اجازممحكمه بحسباب وقف، مطالبه قرض نماند نمايد.

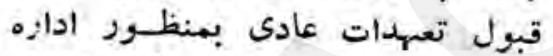

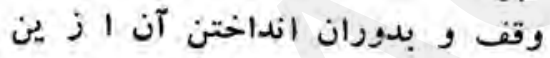

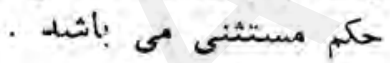

$$
\text { - rar }
$$

هر كاه محكمه مال موقوفـ ر ماده 1 تقسيم وياسبه مستحقين درآنقبلا تعيين كرديده باشد ، ازطرفمنحكه

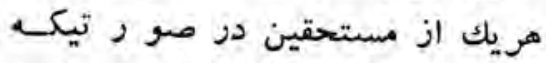

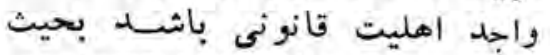
ناظر سهم مربوط به خود تعيبينهى

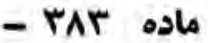

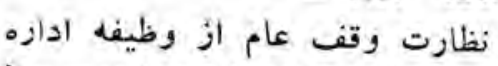

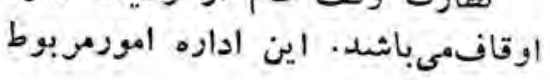

$$
\begin{aligned}
& \text { دريمه فرعه - دوقف اداره } \\
& \text {. }
\end{aligned}
$$

وقف كورونكى به دو قف به به سند

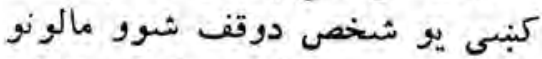

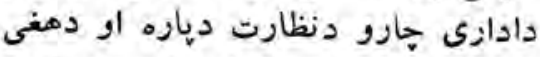

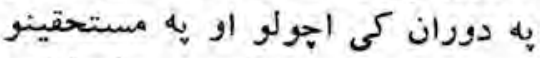

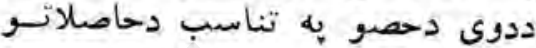

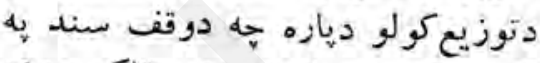

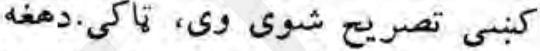

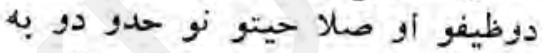

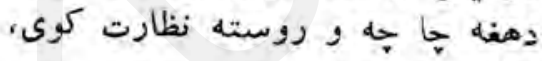
ت

$$
\text { il }
$$

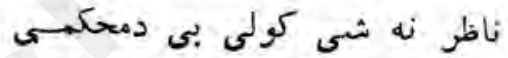

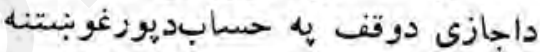

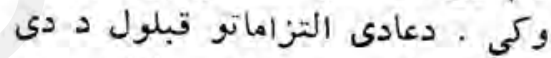

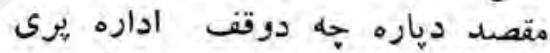

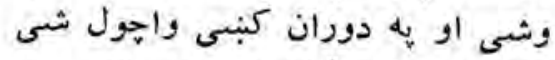

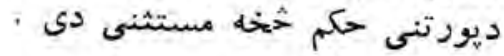

$$
\text { كاده }
$$

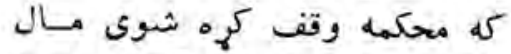

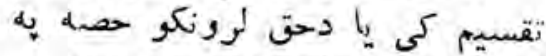

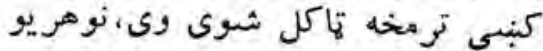

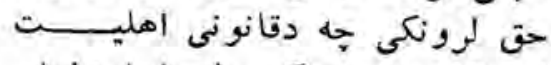

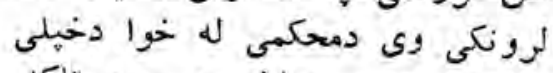

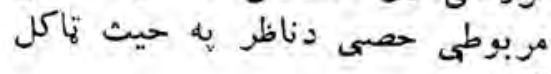
كميب.ى

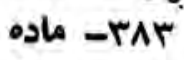

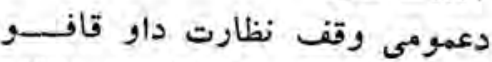
دادارىوظيفهده . . دأ ادارهبه دوقئ داف 


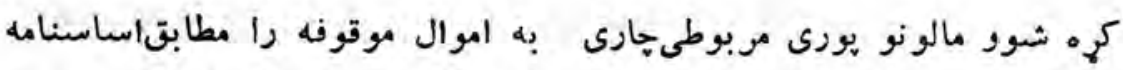

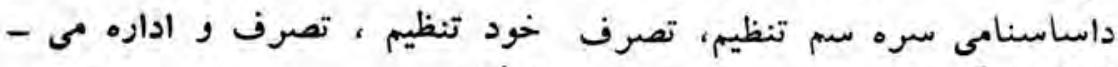
- taE osh او اداره كوى ع عـ- ماده محكمه نمى تواند برأ براى اداره مال

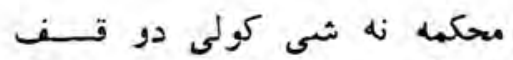
موقوفه بيش از يك ناظر تعيين نمايـ

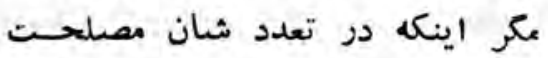

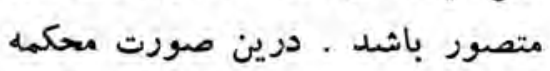
صلاحيت هر يك از ناظرين راتعيين

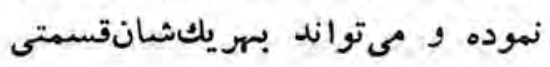
از وقف زا تخصيص بدهد .هر ناظر

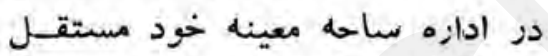

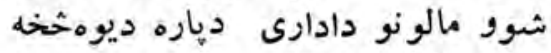

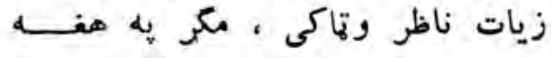

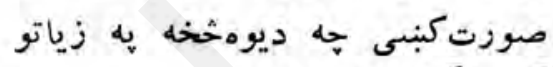

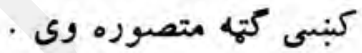

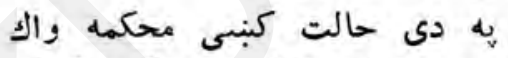

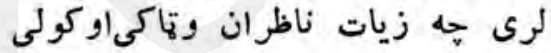

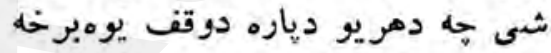
تخصيص

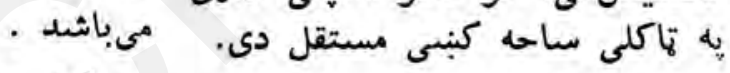
- rao

\section{osk rAo}

هر كاه يكى از مستحقين اهليـت مادت

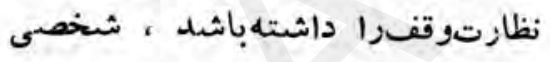
ديكرى بحيث ناظر وقفتعيين شده نمىتواند . در صورتيكة در بـين

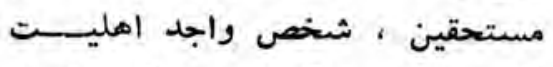

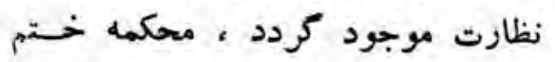
ولايت ناظر ديكر را كه قبلا تعيين

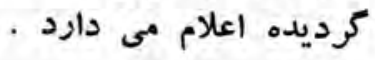

ماده

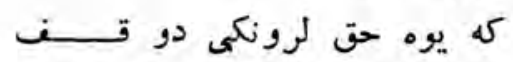

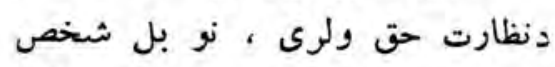

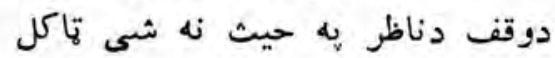

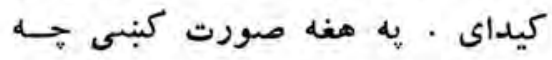

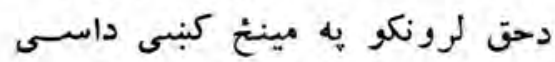

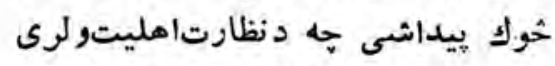

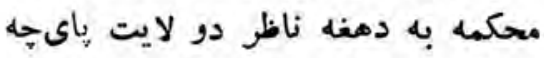
ترمخه تاكل شوى اعلاموى .

\section{דו}

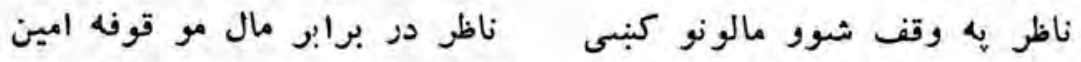

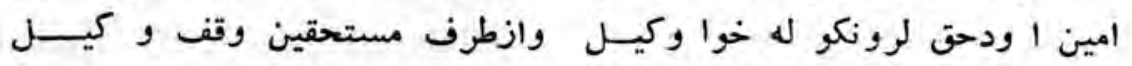
شناخته مى شود . كنل كيب.ى 


\section{- rar oslo}

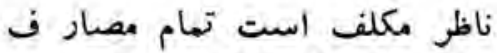

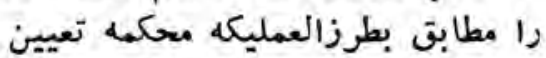

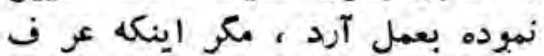
جاريه مخالف آن باشد آند ،

- raA

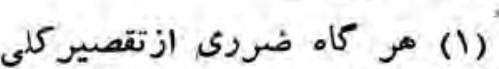

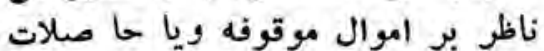

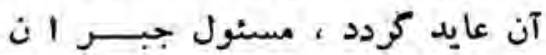

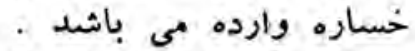

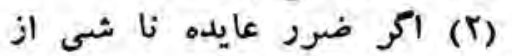

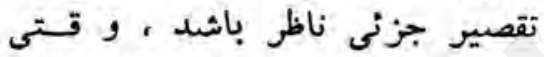

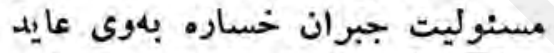
مىكردد كه وظيفه نظارت رادرمقابل

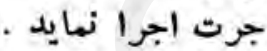

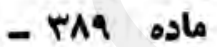

ناظر مكلف دى جها تهول ماده مصرفونه

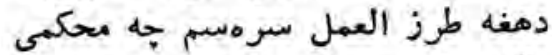

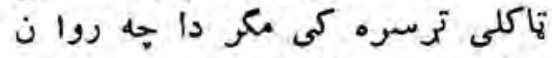

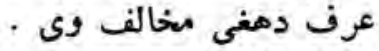
AA (1)

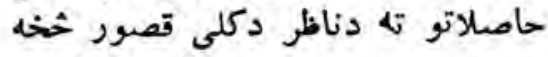

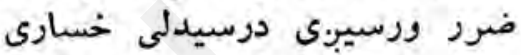
دجبيرى مسنول دى .

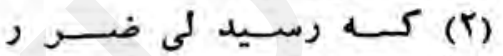

دنسا ظـر دجز نسى قصورخخه ييدا

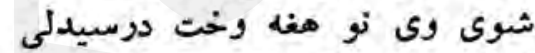

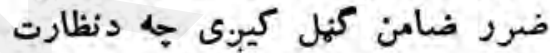

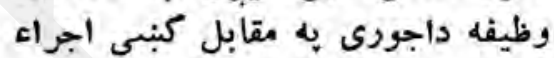
oslo_ra

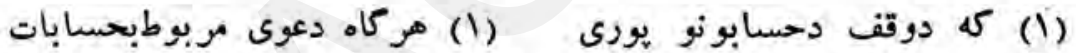

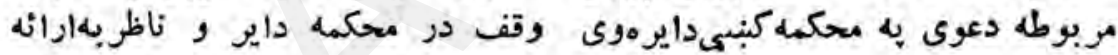

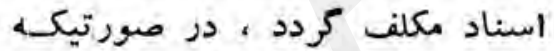
ناظر نتواند حسابات خودرا درميعاد

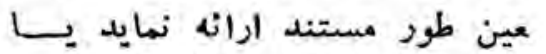

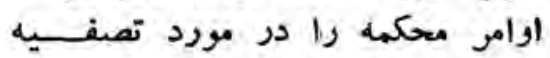

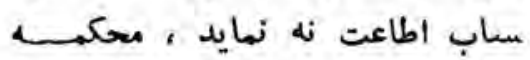

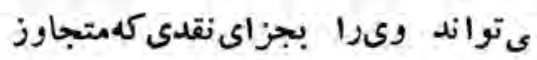

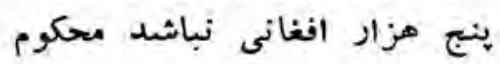
نهايد . . در صورت أكراد بجزائنقدى

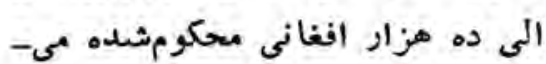
تواند

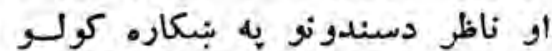
مكلف شى نو به هغه صورت كنبى ديه

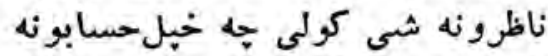

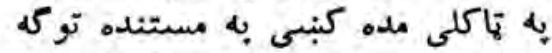

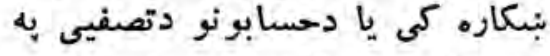

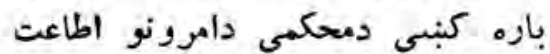

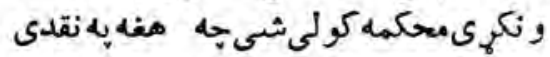
زياته نه وى محكوم كى دئ دتكراء اريدو

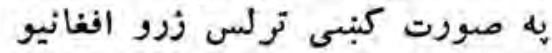

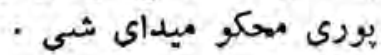

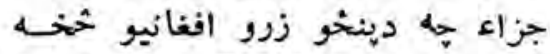




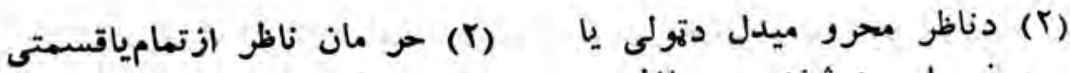

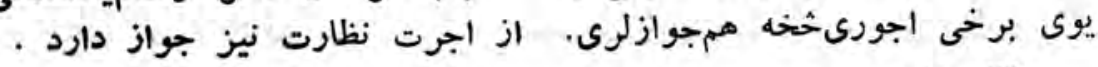

\section{ماده - ماجرت}

.

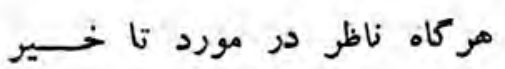

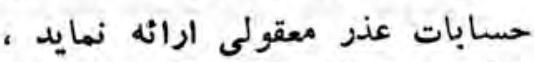

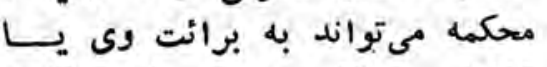

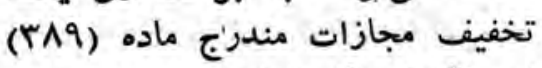
اين قانون حكم نمايد .

\section{ماده آون}

هركاه حين رسيدكى به د عــواى

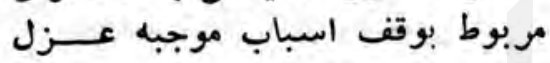
ناظر موجود كردد ، محكمه ميتواند

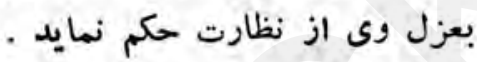

$$
\text { - rar }
$$

محكمه تاوقتيكه حكم دعوىمربوط

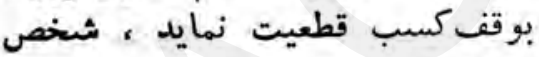

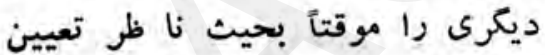

$$
\text { - ماده }
$$

اقراز ناظر مبنى برنظارتش ماردص

$$
\text { ديكر اعتبار ندارد ناطر مارد }
$$

\section{ماده}

ناظر باستيذان محكمه مسى تواند

همه ساله دوفيصد حاصلات و قف بـ

را بمنظور مصارف تر ميم و تعمير

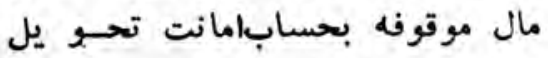

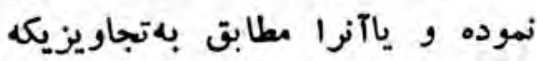

كه ناظر دحسابونو دتاخير يهباره

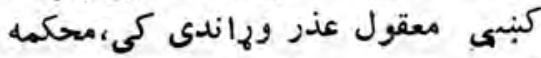

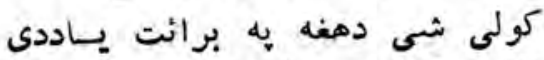

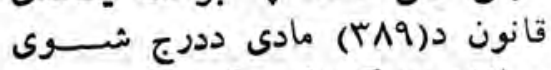
مجازات به كموالى حكم وكى دونى וar- ماده

كه دوقف يورى دمريوطى دعو ى دئ داء

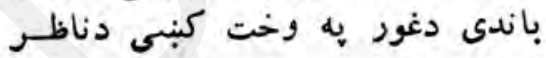
دعزل موجبه سببونه نيداشى ، محكمه دئه

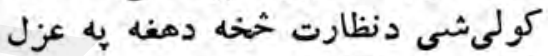
كيدو حكم وكى دنى

$$
\text { rar }
$$

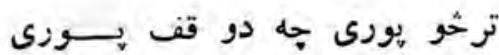

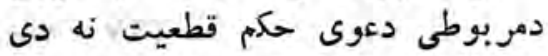

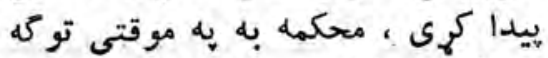

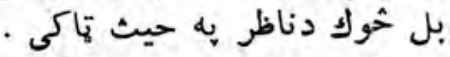

$$
\text { rar }
$$

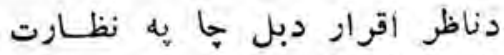
اعتبار نه لرى اقراز

$$
\text { os }
$$

ناظر دمحكمى به اجازه كولى ثمى دوه هر كال دوقف دحاصلاتو خحخه دوهيه

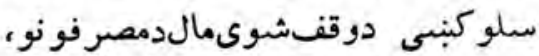

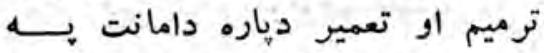

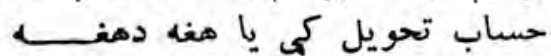

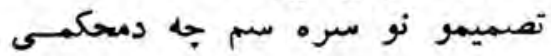




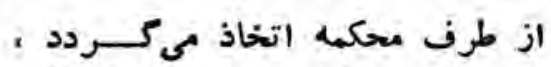
بعصرف رسانيده و بدو انخاذ ران اندازد.

$$
\text { - rao }
$$

هر كاه ناظل ويا مستحقينتحويل

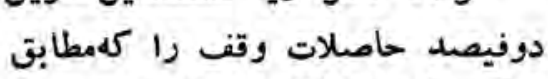

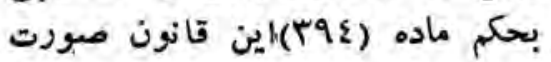

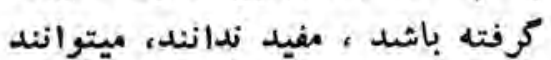

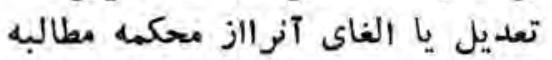

$$
\text { - rar }
$$

\section{هر كاه براى تعمير و تـر ميسم}

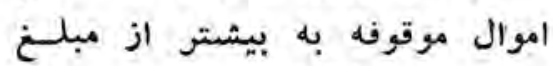

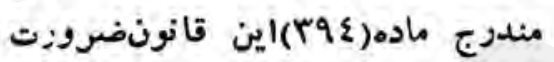

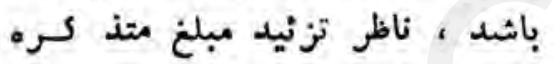

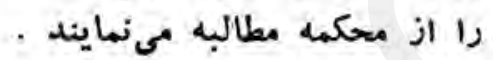

$$
\text { - rav oblo }
$$

محكمه مي تواند بمنظور تعمير و ماده

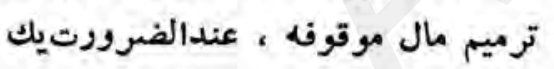
تسمت از مال مو قو فه را بفروش مونس برساند

فرع حهارم - انتهاى وقف

$$
\text { - ras }
$$

وقف موقت باتكميل مدت معـينه

، يازبين رفتن تهام موقوف عليهه ؛
له خوا نيول كيبيى مصرف كى او به بيه

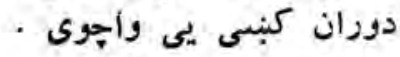

\section{oslo}

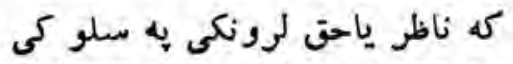
دوه دوقف دحاصلاتو حخانه تحوئ تحويلول

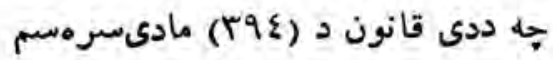
يى صورتموندلىوى، كتيهورونه كثي،

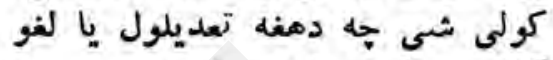

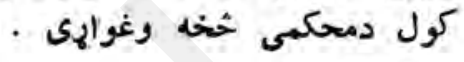

$$
\text { }
$$

كه دوقف شوو مالونودتعمير او

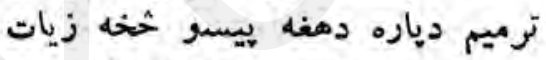

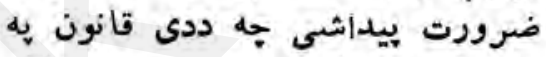

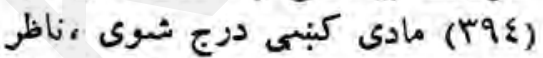

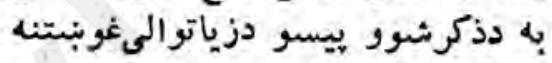

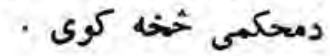

$$
\text { olo_rav }
$$

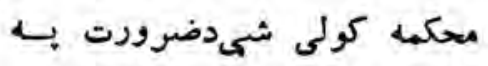

وخت كنبى دوقفشوو مالونودتعمير او ترميم دياره دوقف شبوى دوفي مال يوه . برخه خرخه كمين

خلورمه فرعه - دوقفياي تهرسيدل

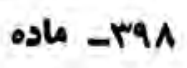

موقتى وقف دتاكلى مدى به بوره كيدو يا دتولو مغه خلكو دمنخهتلبو به نسبت جه مال ورته وقف شوى، باى ته رسيبوى نه 
وقف در مورد هر سهم بازاز بين

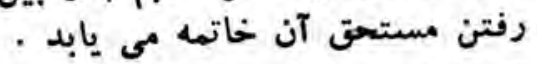

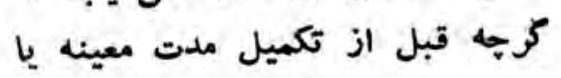
از بين رفتن باقى مستحقين طـبـهـ ايكه بااز بين رفتن شان وقف ماقى منتهى

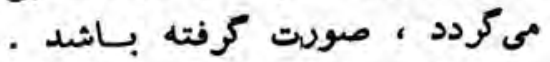

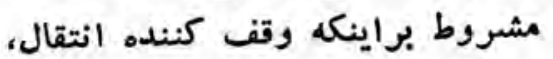

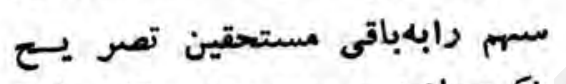

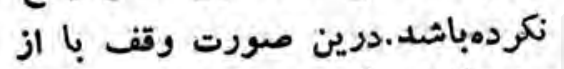

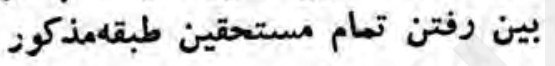
ويا تكميل مدت معينه خاتههمىيابد.

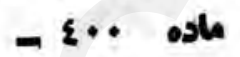

مركاه وقف در تمام اسهامثابته

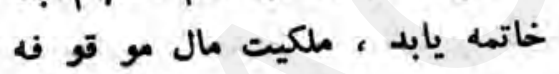
در صورت حيات وقف كنيده بيخود وى ودر غير آن به مستحقين انثقال

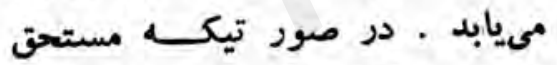
موجود نباشد ملكيت مال مو قوفي موري باشخاصيكه حين وفات وقف كننده ازجمله ورثه شيناخته شيده بـاشند وفيند

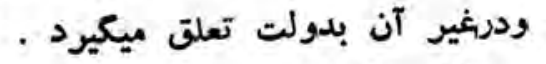

$$
\text { - عادم }
$$

هر كاه وقف در تمام اسبهام غير

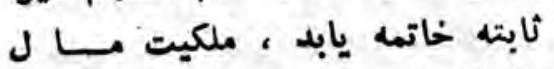

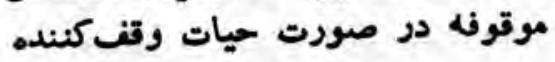

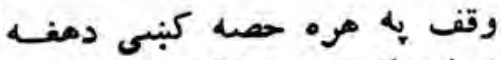

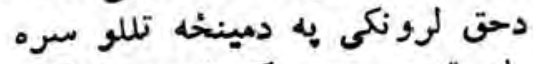

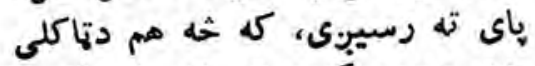

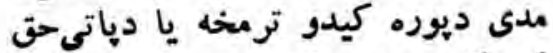
لرونكو دمغى طبقى يه دمينخه تلبه

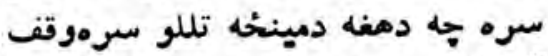

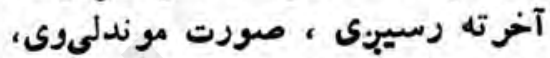

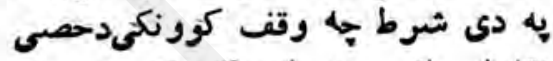

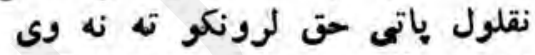

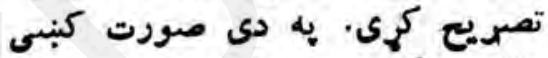

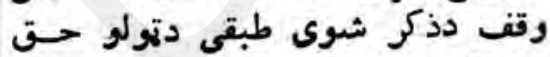

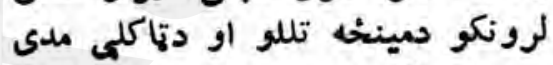

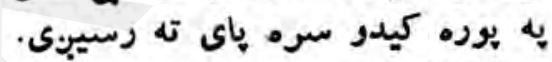

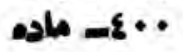
كا وقف يه تولو ثابتو حصو كنبى

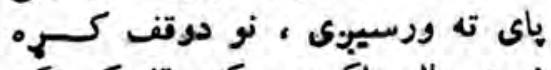

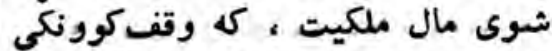

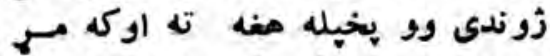

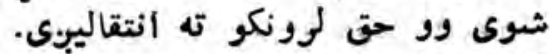

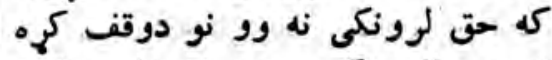
شوى مال ملكيت مغه اشخئه

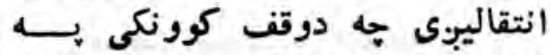

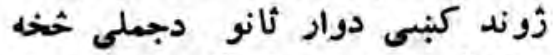

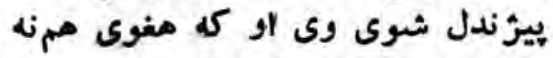

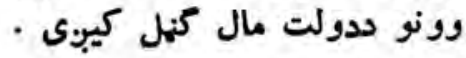

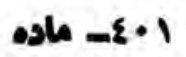

كه وقف به تولو ناثابتو حصو كنبى

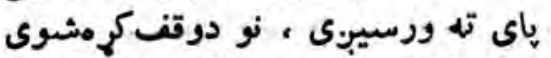

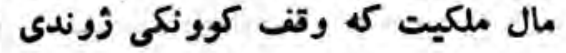


بخود وى و در غير آن بهاشخاصيكه

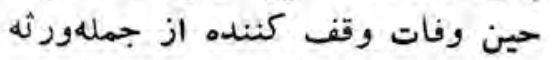

شناخته شده وفات وقاشيند انتقالمييابد ازيله

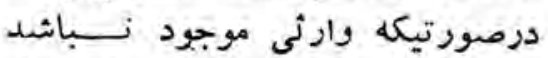

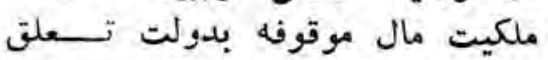

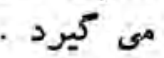

$$
\text { ماده }
$$

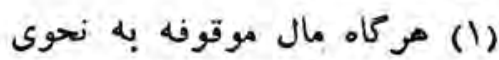

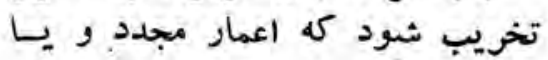

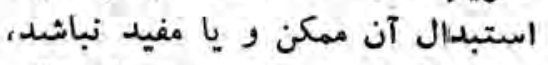

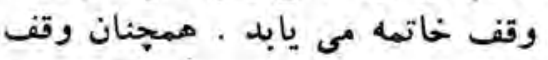

دزمورد سته هو مستحقيكه سمهيك

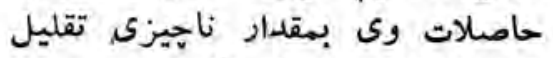

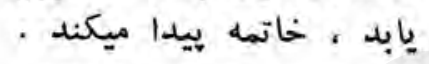

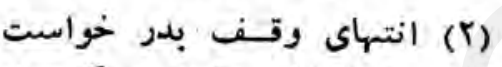

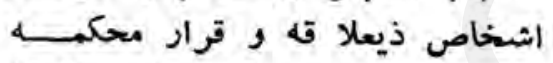

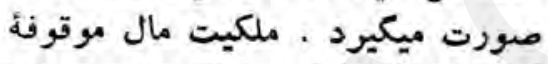

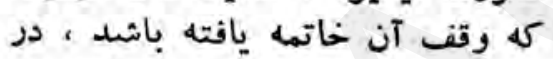

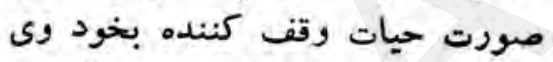

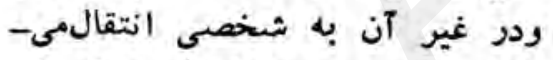

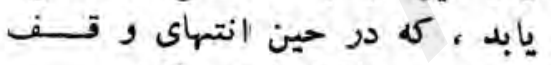

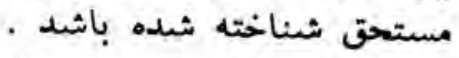
مبحث سوم - جمعيت فرع اول - احكام عمومى مئى ماده

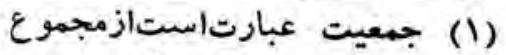

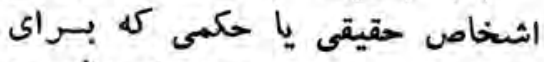

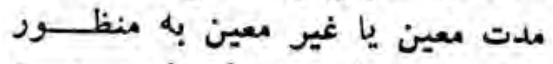

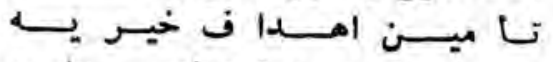

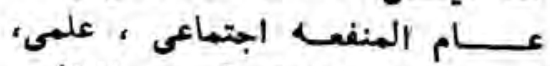
ادبى ، فنى و منرى طورغير انتفاعى أحسى
وو بخيله مغه ته او كه مغه زثرندى

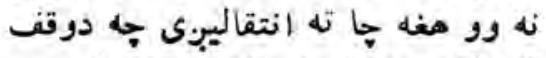

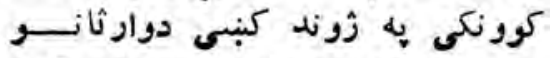

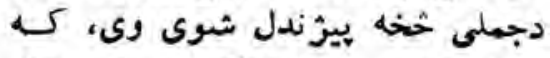

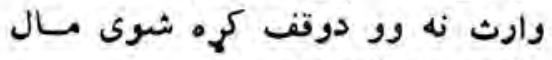

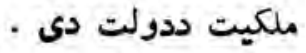
صاد (1)

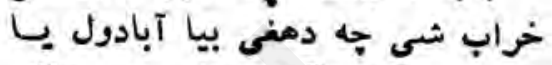

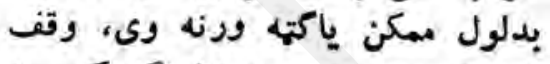

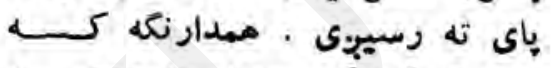

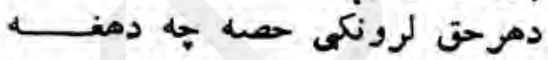

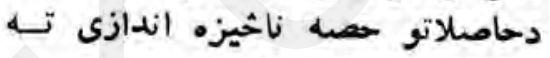

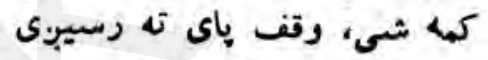

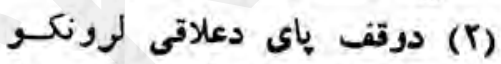

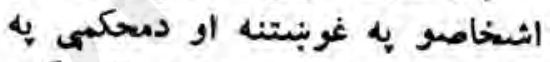

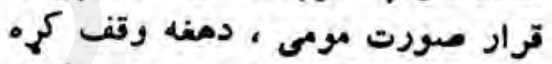

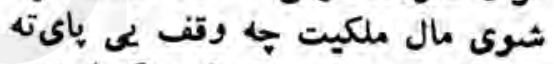

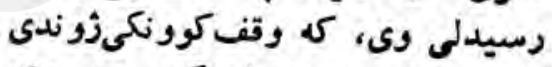

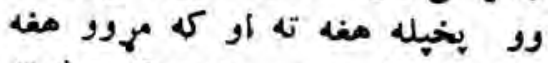
جاته انتقال مومى جه به دوقفديائه

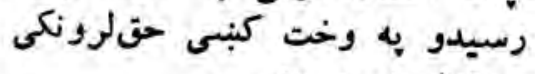

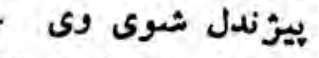
دريم مبحث - جمعيتون فئه لمرى فرعه - عهومى حكمونه

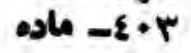

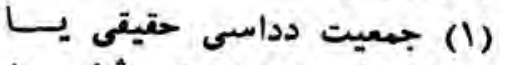

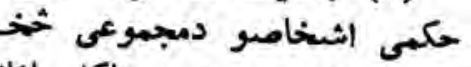

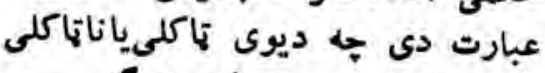

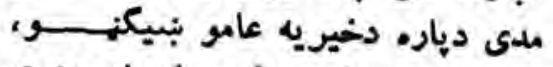

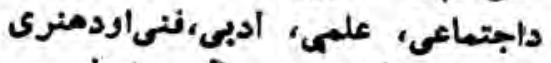

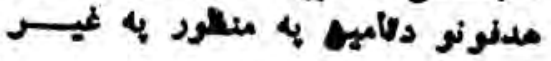


انتفاعى توكه ددى قانون دحكمونو مطابق به احكام اين قانو ن تشكيل

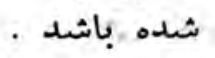

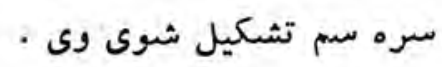

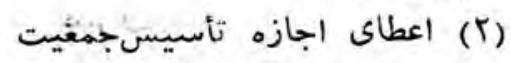

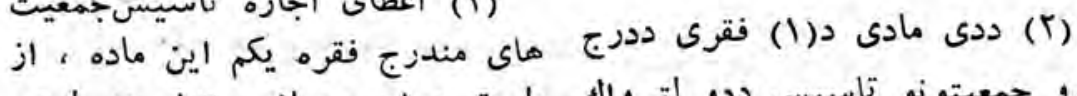

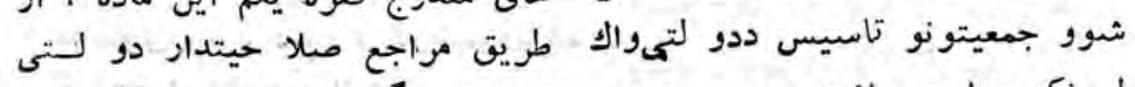

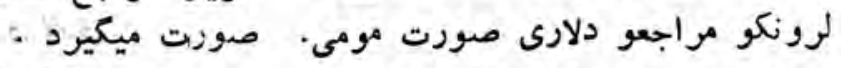

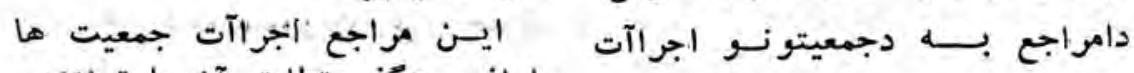

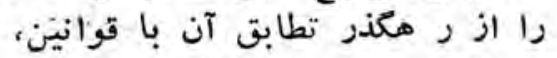

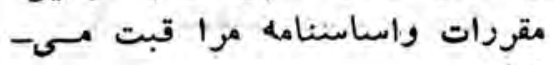

$$
\text { نمايد مقرات }
$$

\section{- ماده}

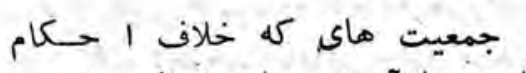

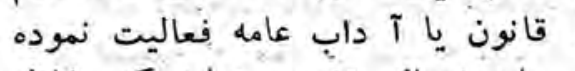

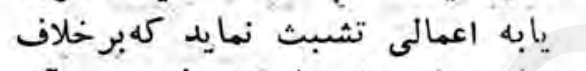

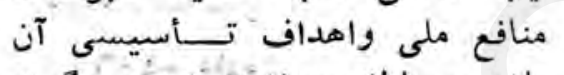

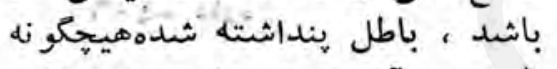
اثرى بر آن مر تب شاطل شيده نميتواند.

$$
\text { ماده }
$$

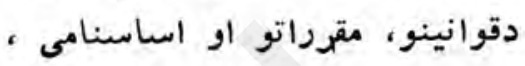

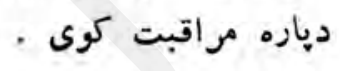
كوم جمعيتونه حه دقانه

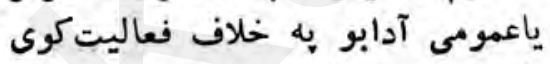

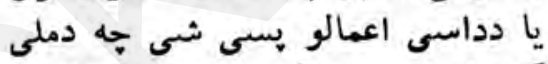

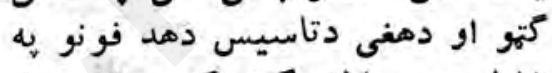

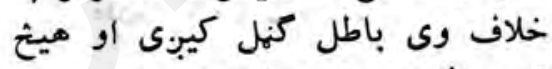
ماده

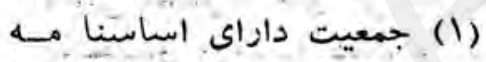

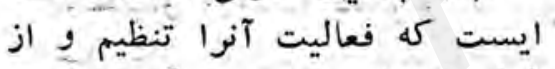

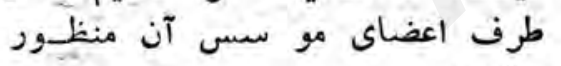
ميشود اعرف اعض

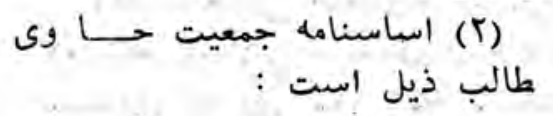

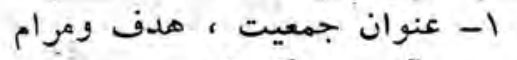

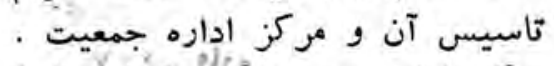

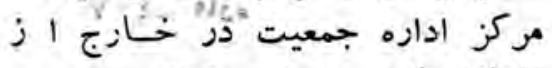

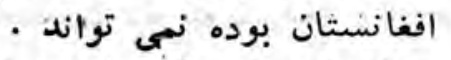

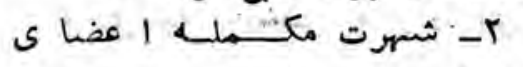

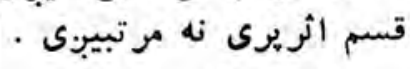

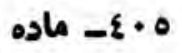

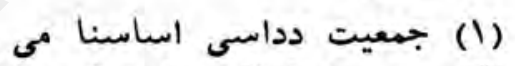

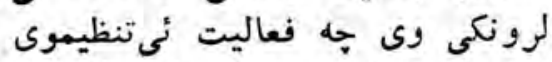

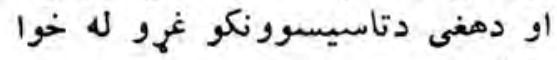

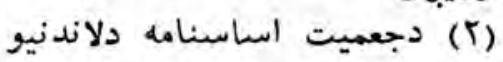
مطلبونو لرونكى دى : دجعيت انسان

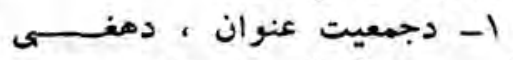

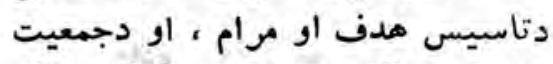

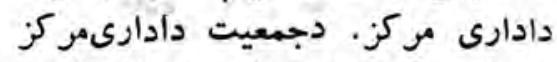

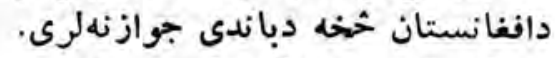
ז- تاسيسوونكو غهو • شهرت 


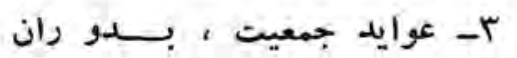
نداختن وتصرف درائ

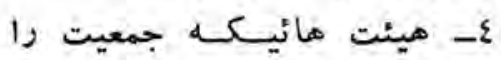

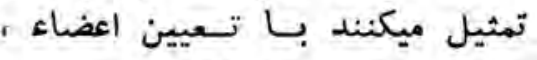
وظايف وطرق عزل آ نها تهيل

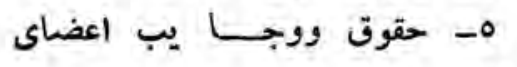
موسس - م

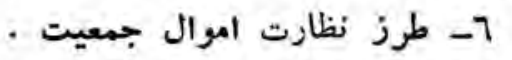

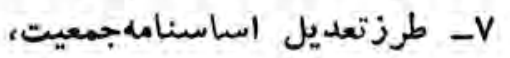
الحاق ، تقسيم و تاسيس نمايندكى.

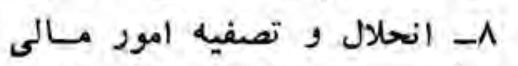
جمعيت و مر جعيكه اموال به به المورل

$$
\text { انتقال مى يابد ماده }
$$

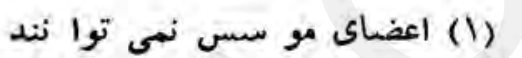
بنان مطالبى را در اساسنامهاجمعيت

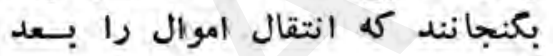

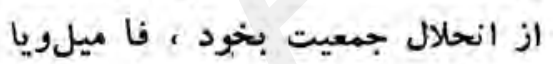
ورثله ثان مجاز قرار دهد . (T) اسهام جمعيت هاى تماونى

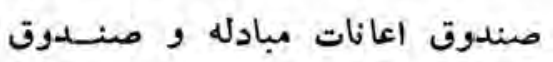
تقاعد ازين حكم مستثنى مىباشيد , ماوف

$$
\text { ماده }
$$

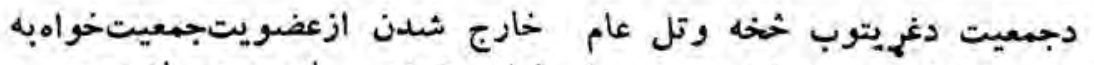

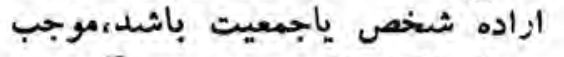

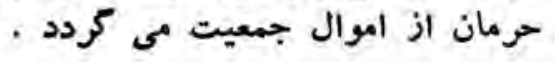

r- دجمعيت عايدات ، دهغى بــــ

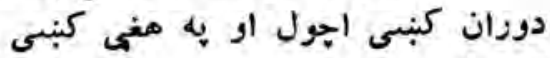
تصرف

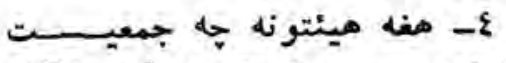
تهنيلوى سره دغروأو دوظيفودتهاكلو

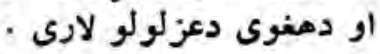

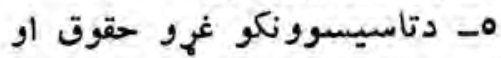
وجايب

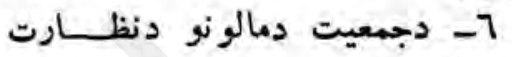
• طرز العمل

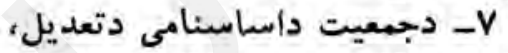

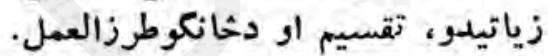

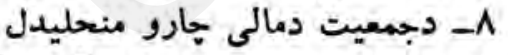
او تصفيه او هغه مرجع جها مالى مالونه

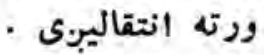

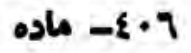

(1) كولى جه دجمعيتيه اساسناله كبنى

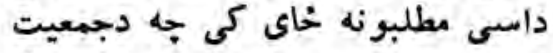

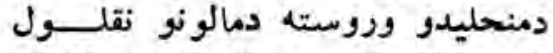
خيل خان، كورنى يا خيلو وروني وارثانوته

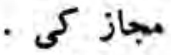
(r) دماز كى دماونى جمعيتونو سمهونه،

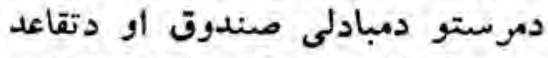

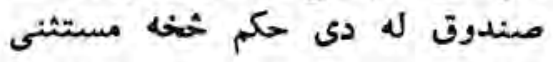
د دى

$$
\text { ماد }
$$

له دى حه دشخص يه ارأده وى يـان وتئ

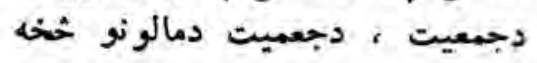


دمحرو ميدو موجب كرخى، مكر داجه مكر اينكه در قانون مسخالف آ ن

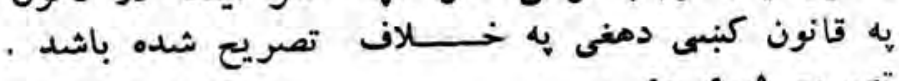

$$
\text { - }
$$

جمعيت نمىتواند مالك إهو 1 موا ل

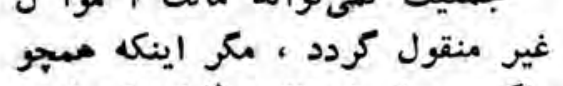

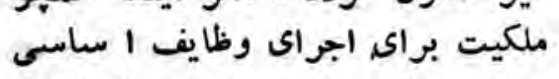

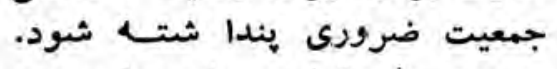

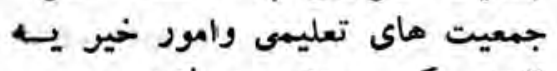

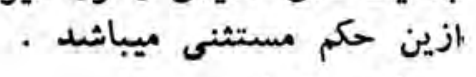

$$
\text { ماده }
$$

شخصيت حكمى جمعيت و قـتى مادى

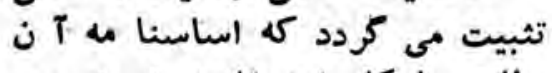

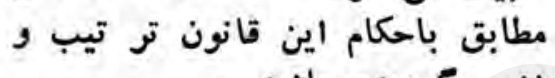

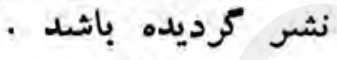

$$
\begin{aligned}
& \text { ماده . }
\end{aligned}
$$

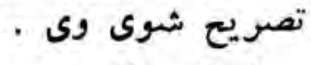

$$
\begin{aligned}
& \text { 1• }
\end{aligned}
$$

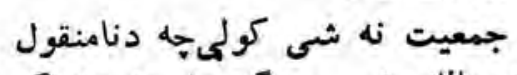

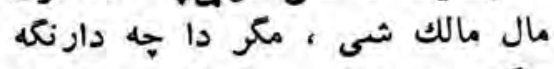

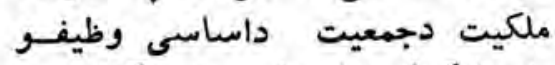
داجرا كولو دياره ضرورى وكنهل تعاونى او خيريه جمعيتو نه ددى حكى حكي

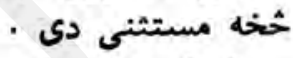

$$
\begin{aligned}
& 9
\end{aligned}
$$

دجمعيت حكمى شخصيت هنهـيـه

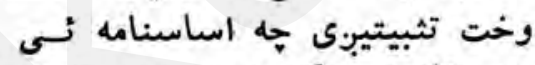
ددى قانون دحكمونو سره سيتين سمتري

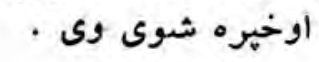

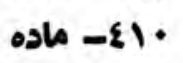

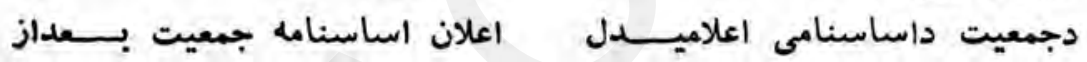

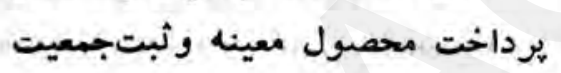

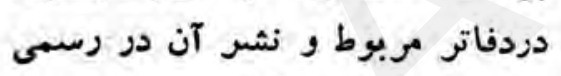

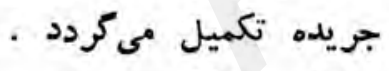

$$
\begin{aligned}
& \text { - Ell }
\end{aligned}
$$

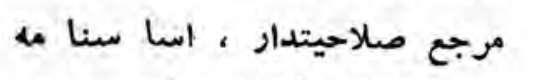

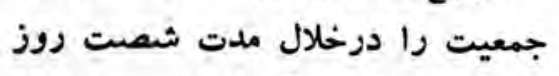

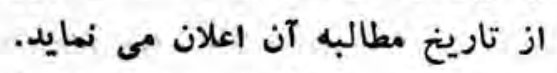

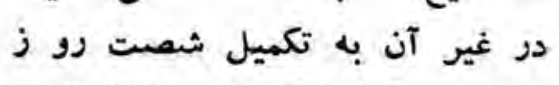

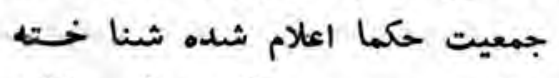
ميشود · مرجع مذكور باثر ماثر مطالبه

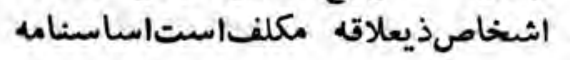

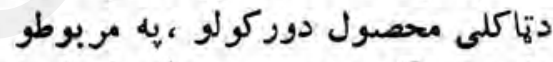

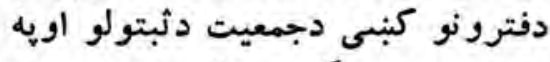

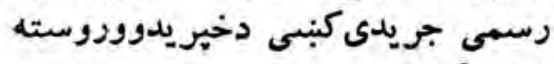
يوره كيبين.

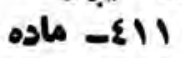

واك لرونكى مر جعع به دجعميـــت اساسنامه دمغه دغوبنيتنى دنيته دخخه

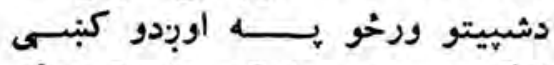

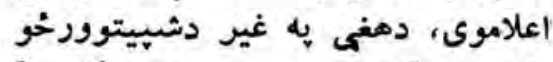

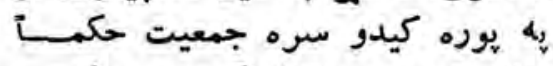

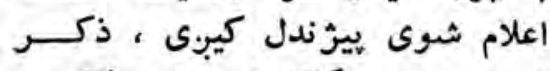

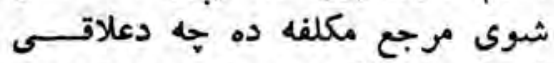

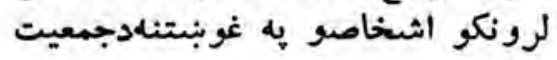




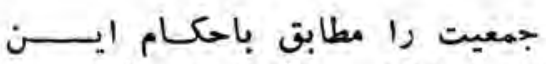

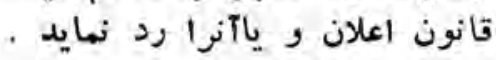

\section{- Elir}

تعديل اسفاسناهه جمعيت بارهائ

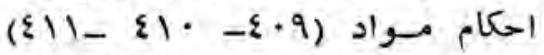

اين قانون بعد از اعلان أعان نافذ شمرده

$$
\text { - Elr }
$$

جميت مراتب آتى را راه عايت

$$
\text { مىنمايد : }
$$

ا- نكهدارى دفاتي واسنادمربوط

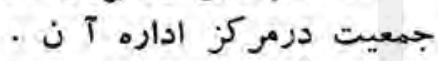

r- ثبت اسم ، ولد، اسمفاميلي،

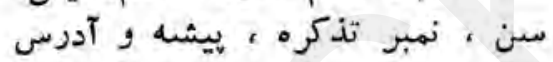

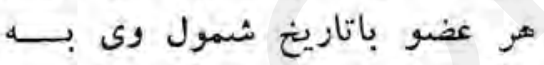

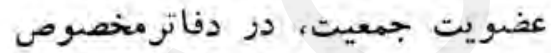

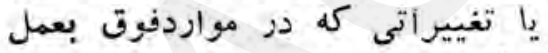
مى آيد

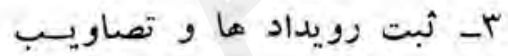

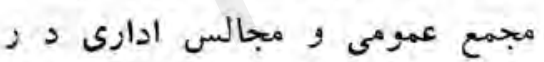

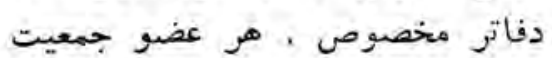

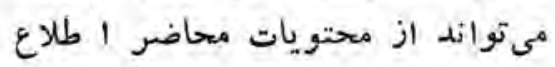

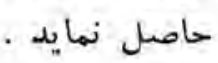

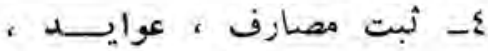

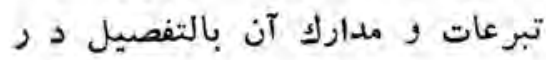

دفاتر مخصوص صورت مى كيرد . مئر

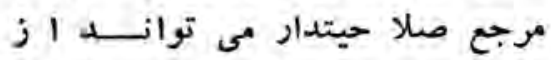

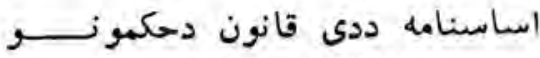

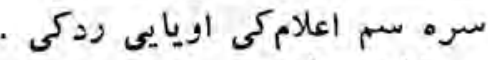
זוع- ماده دجمعيت داساسنامى تعديل داوه دوى

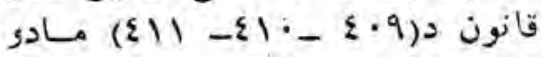

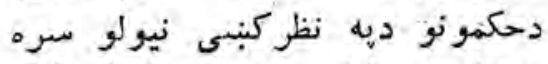

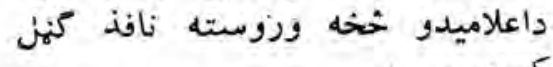

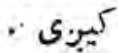

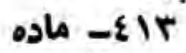

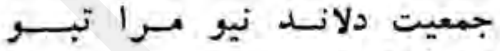
مراعت كوى :

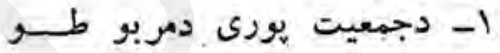
دفترونو او سندونو ساتنه دهغ ونه

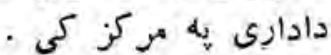

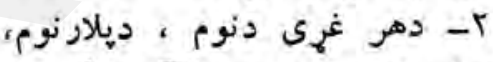

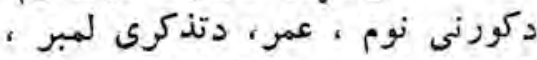

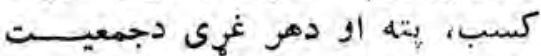
دغيتيتوب دشا مليدلو دنيتهى سره ديه ديه

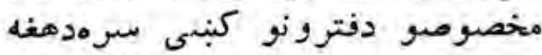

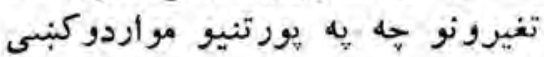
كيب.ى ، ثبتول

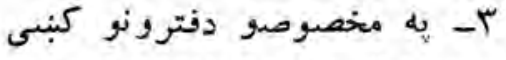

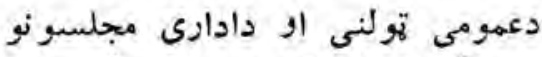

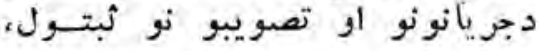

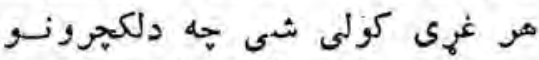

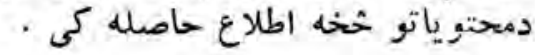

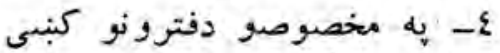

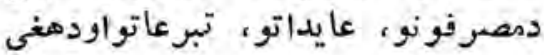

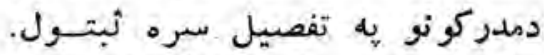

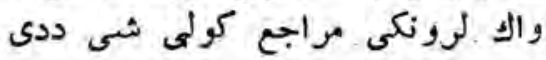


سندونو او لكجرونو دمحتوياتو خخهه محتويات اين اسناد و محاضراطلاع

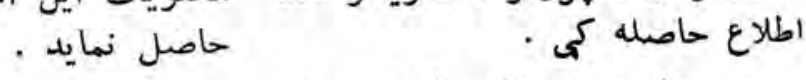

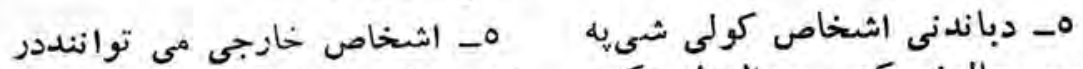

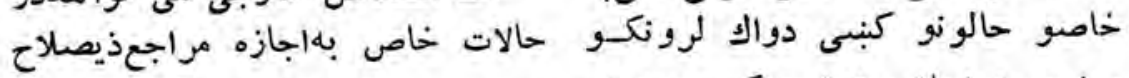

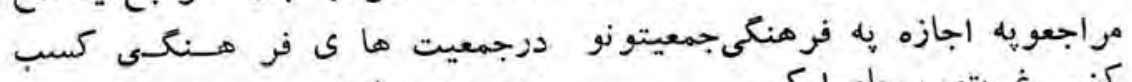
عضويت نمايند

\section{- ماده}

(1) جهعيت مكلف استبـاجازه

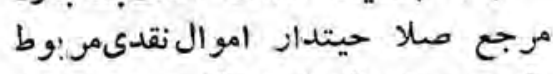

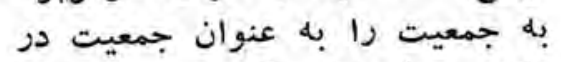

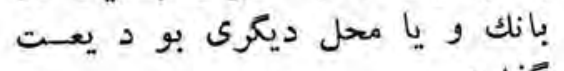

$$
\text { كذاز2 }
$$

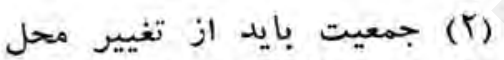

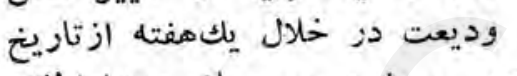

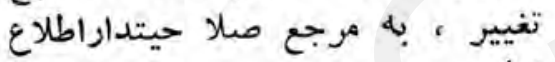

$$
\text { ـ ماده }
$$

اموال مربوط به جمعيت بـ بـراى

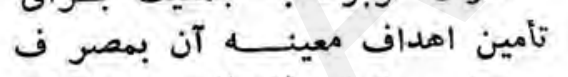

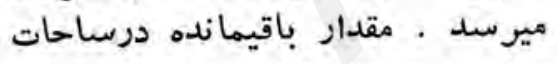

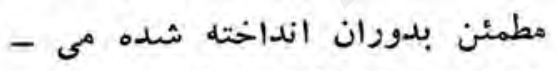

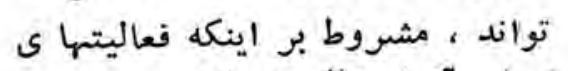

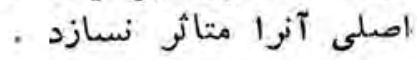

$$
\begin{aligned}
& \text { - El7 }
\end{aligned}
$$

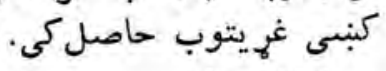

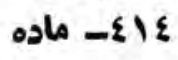

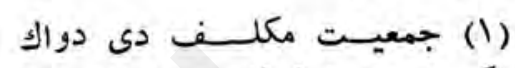

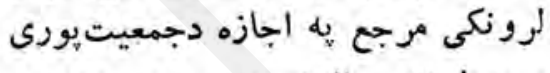

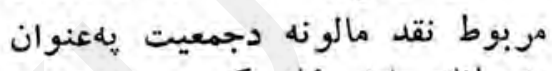

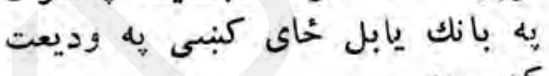

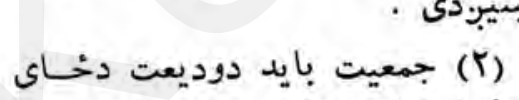

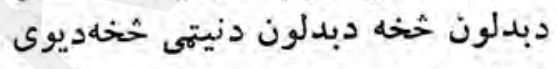

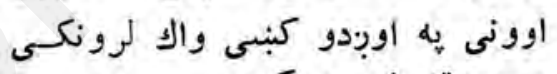

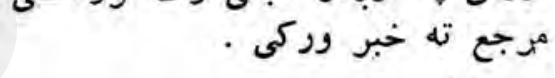

$$
\text { داده }
$$

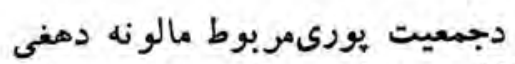

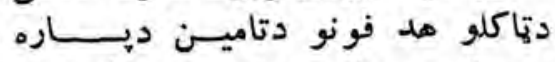

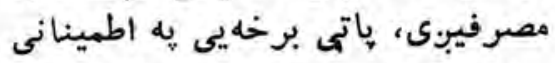

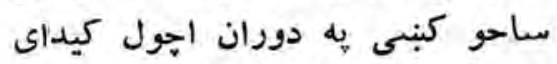

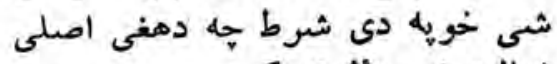

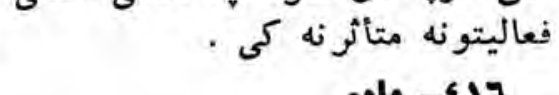

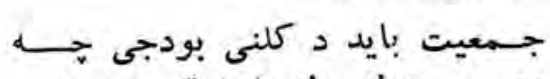

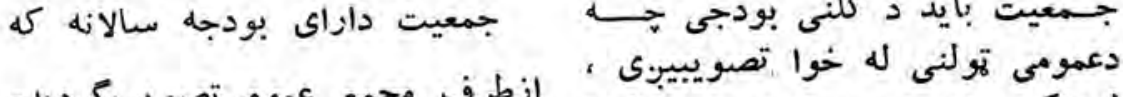

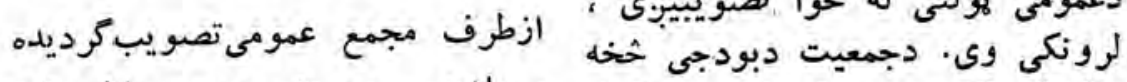

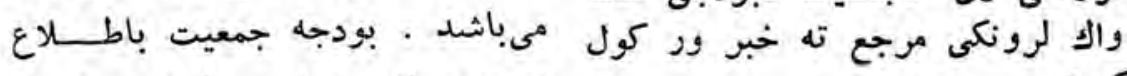
مرجع صلا حيتدار زسانيده ميشود. كيبنى 


\section{- EIV ماده}

جمعيت نمىتواند خارج ازحهدودى

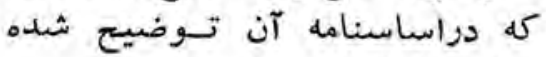
فعاليت نمايد كالهالمان

\section{- El1}

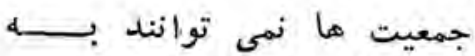
مضاربت مالى تشبث نمايند

\section{- El9}

و (1) اسم جمعيت ، شماده (1) شماره اعلان

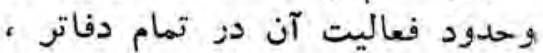

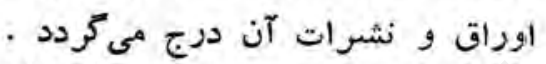

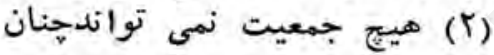

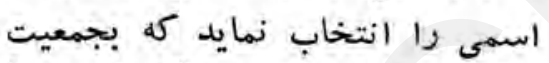

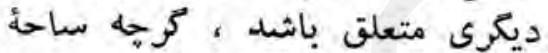

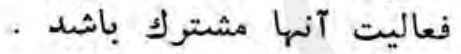
- ET. مإ

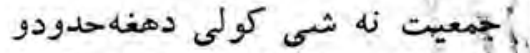

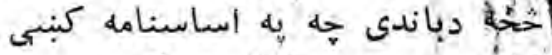

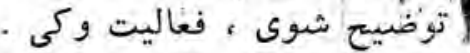

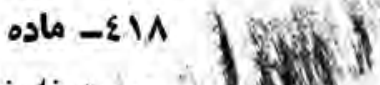

| |

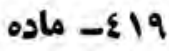

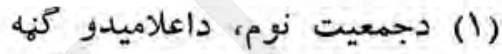

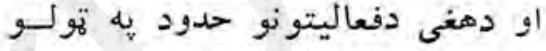

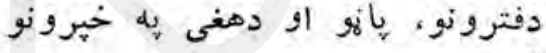

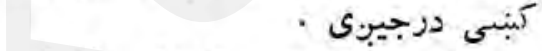

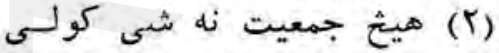

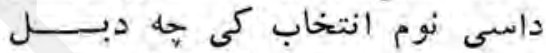

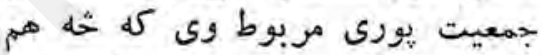

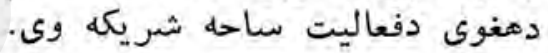

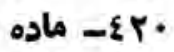

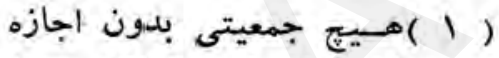

بو (1)

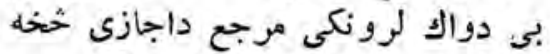

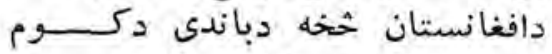

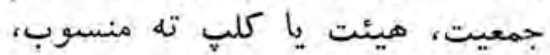

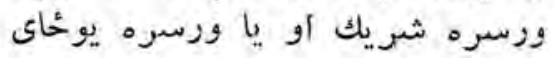

إلى (r)

بي

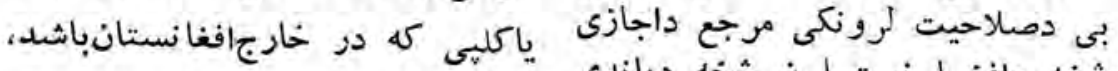

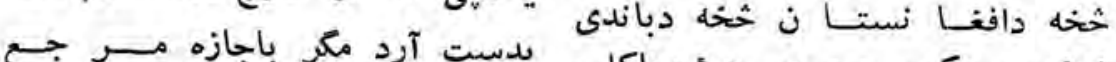

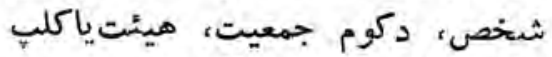

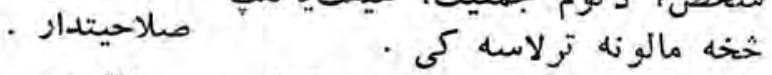

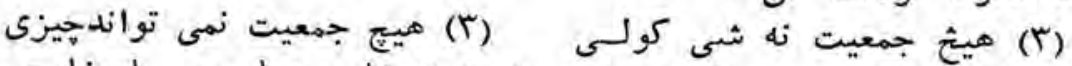

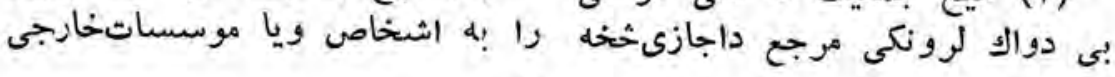


بدون اجازه مرجع صلا حيـــتدا ر بفرستد بل اجازه - ماده

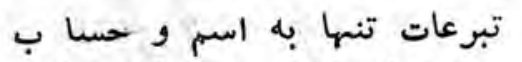

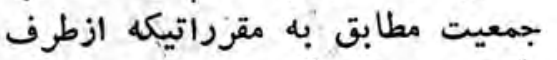

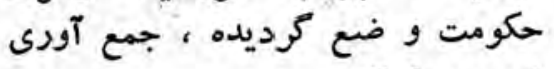

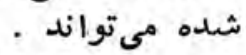

مرجع صلاحيتدار مىتوانداندشرائط

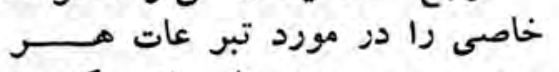

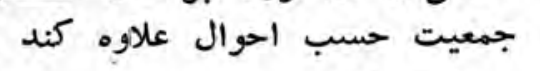

$$
\text { - Err }
$$

(1) جمعيت بايد انعقاد واجنداى

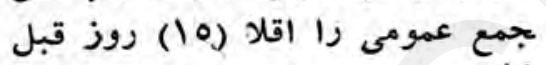

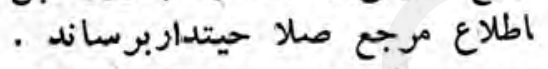

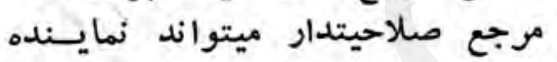
ايرا غرض اشتر أك در مجمع عمومى مئى

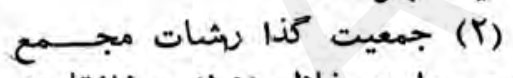
مومى را در خلال (10) روزازتاريخ نعقاد آن ، باطلاع مرجع صلاحيتدار روزاريخ

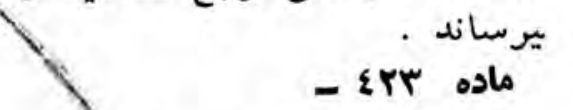

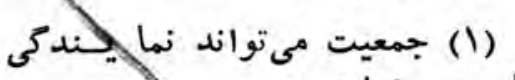
: أسيس نمايد جمعيت

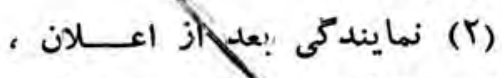

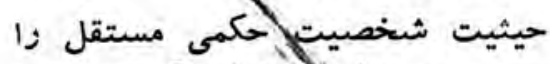
سبب مى نمايبل . نمايندكى نميتواند

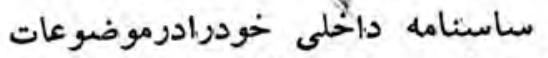
مربوط به وجايب آندر برابرجمعيت
دباندنيو اشخاصو يا موسسو تــــ

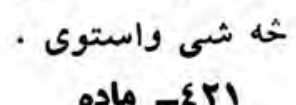
تبرعات يواخحى دجمعيت يه نامسـ ماهـ

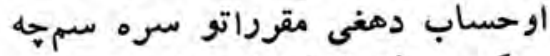

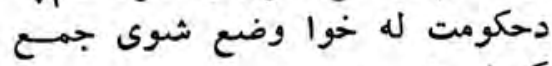
كيداى شى • واك لرونكى مراجع كولى شـى شـــى

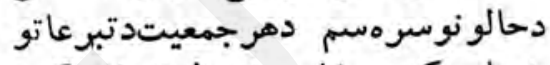

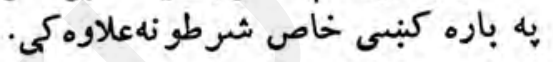

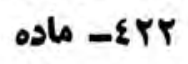

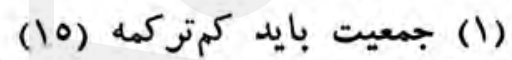

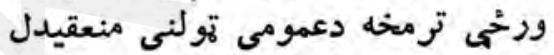

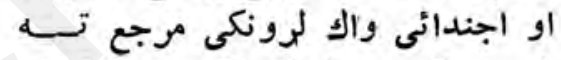
خبر وركى · واك لرونى واك لرونكى مرجع موجع كولى

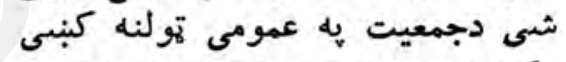
دكثون دياره يو نماينده واستوى دمعيت نولنه

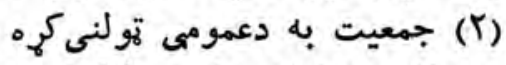

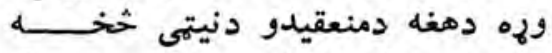

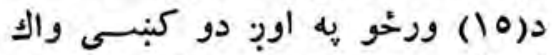
لرونكى مرجع ته خبر وركوى له اوب دوكني r

(1) جمعيت كولى شى نمايندكى • تاسيس كى (1) د) (r) نمايندكى داعلاميدو وروسته

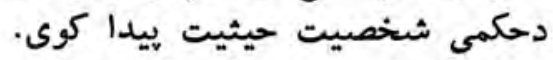

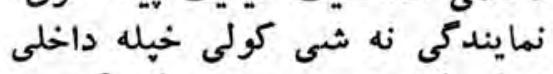

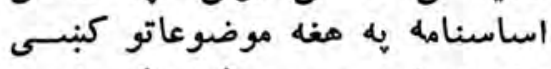

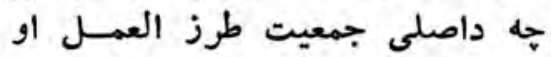
دجمعيت دعمومى سياست ديه يه مقابل العمل 


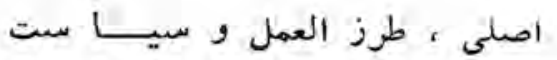

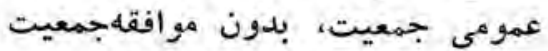
اصلى تجديل جمائ نمايد

$$
\text { فرع دوم - هيئت مديره }
$$

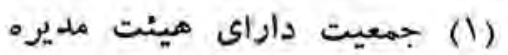

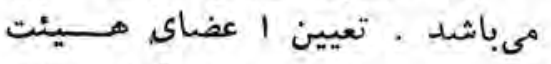

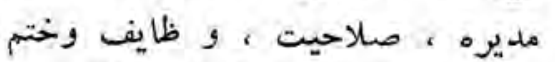

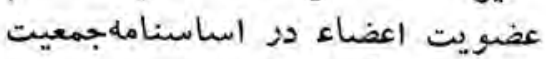

$$
\text { توضيت مى كردد . }
$$

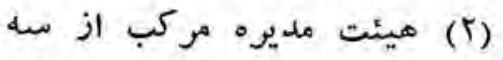

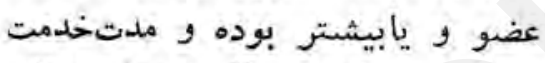
شانبيش از سلسال بوده نميتواند.

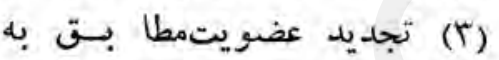

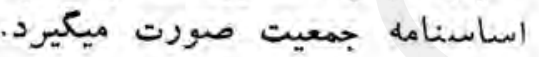

$$
\text { - ETO }
$$

شخصيكه به صفت مضاه

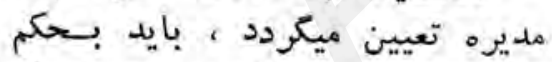

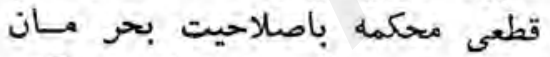

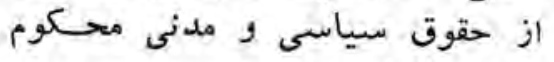
نشده باشد از ماند

\section{ماده רצז}

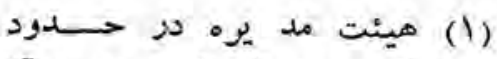

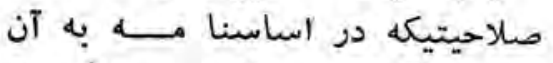

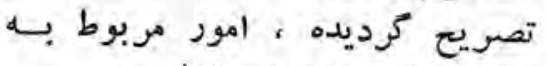

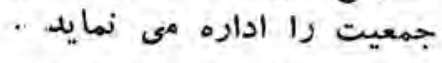

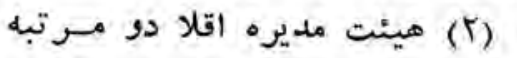

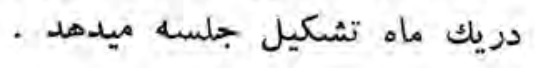

كثبنى دهغى دالتزاماتو يورى مربوطى

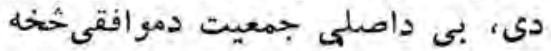
·

$$
\text { دوهمه فرعه - مديوه هيئت }
$$

$$
\text { ماد }
$$

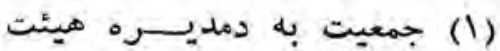

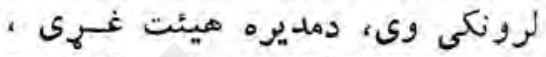

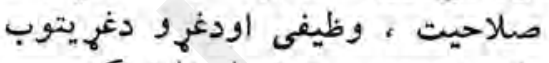

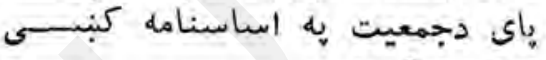
توضيح كيبيى

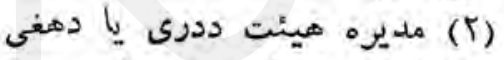

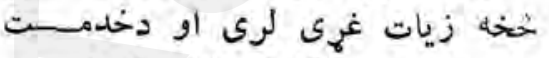

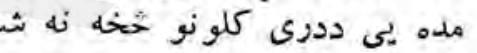

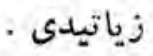

واسنا

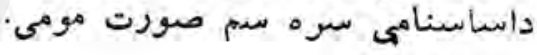
ماد

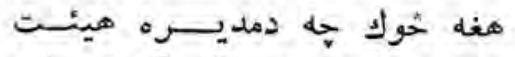

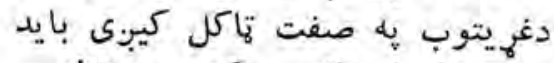
حطي

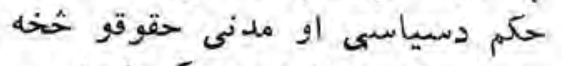

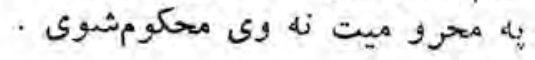

$$
\text { רץז }
$$

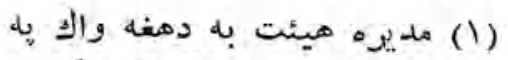

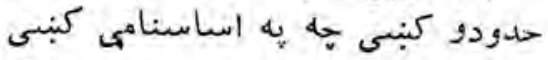

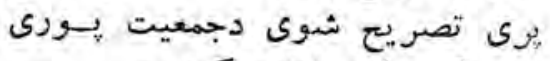

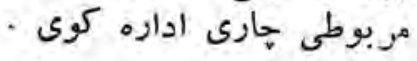

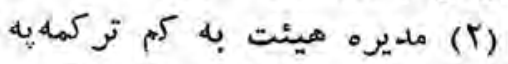
هياشت كنبى دوه كرتى غونلهوك. 


\section{- Epr osto}

هيئت مديره شخصى راد را ازجمله عضاى خود ياديكر اعضاى جمائت جمعيت - جيث رئيس تعيين مينمايد ادئ

$$
\text { ماده }
$$

شخصيكه از طرف هينت مدئ مديره

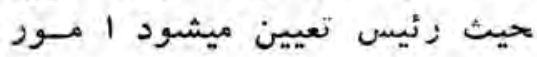

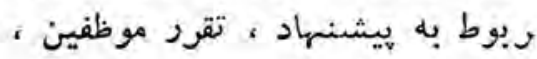

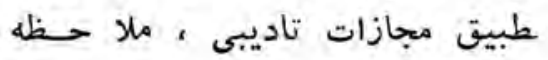

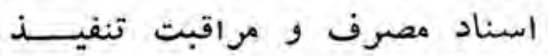
صاويب مجمع عمومى وهيئت مديره

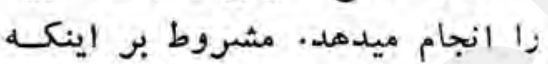

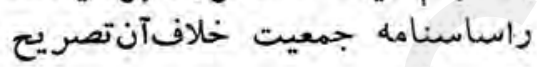

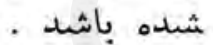

$$
\begin{aligned}
& \text { فرع سوم - مجمع عمومى } \\
& \text { م م - ماده }
\end{aligned}
$$

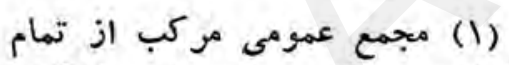
عضائيست كه وجايب خودردامطابي المبام

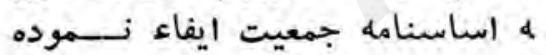

ز) (T) تصاويب مجمع عمومى خارج أمنات

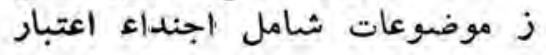

$$
\text { مدارد . موضرع }
$$

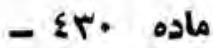

تصاويب مجمع عمومى بإكثريت

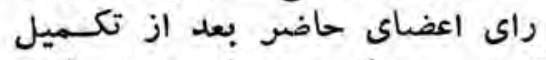

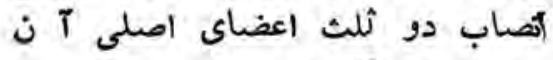
صورت مى كيرد .

$$
\text { ه S EYV }
$$

مديره هيئت به يو شختص دخهيلو

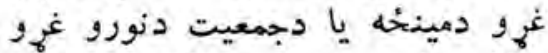
> ش

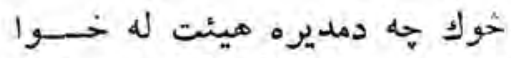

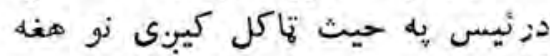

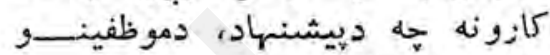

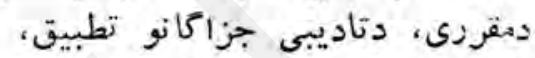

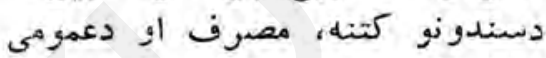

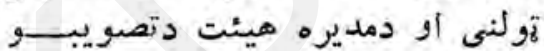

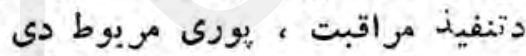

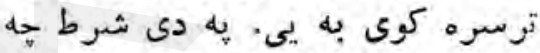

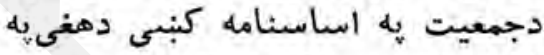

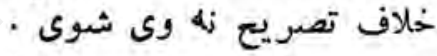
دريمه فرعه - عمومى تولنه osb - Erq

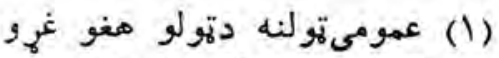

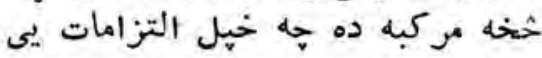
دجمعيت داساسنامى سره سمترسه - كرى

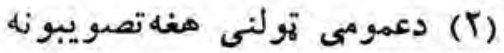

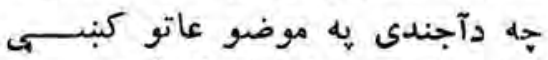
شامل نه واجندى، اعتبار نه لرى ون.

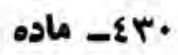

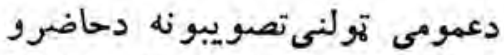

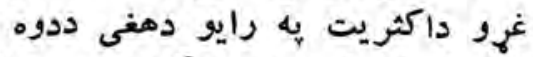

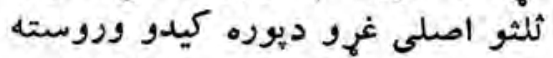

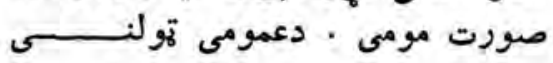


تصاويب مجمع عمومى در مورد تعديل اساسنامه جمعيت به اكموني

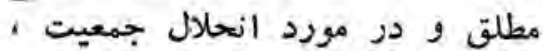
عزل اعضاى هيئت مديره ، اتحادول جماليا

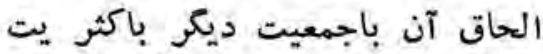
دوثلث اعضاء صورت مى آنيرد. مكر ديك اينكه در اساسنامه جمعيت خـلاف آن تصريح شده باشد آشاند

$$
\text { ماده }
$$

در جلسات مجمع عمومى اعضاء

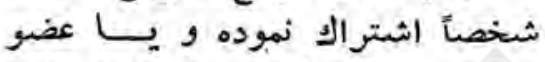

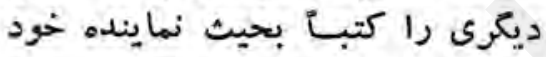

$$
\text { تعيين مينمايند . }
$$

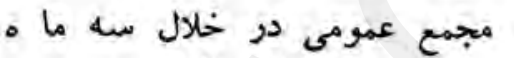

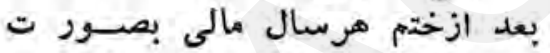

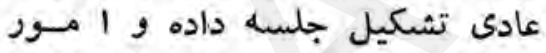
مربوط به بودجه ، حساب سلال تمام

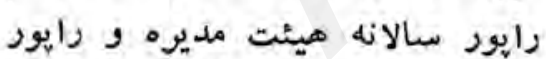

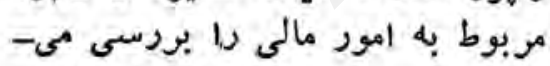
نمايد . تشكيل جلسات فوق العاده

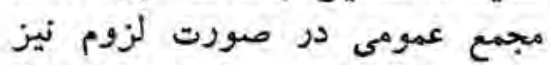

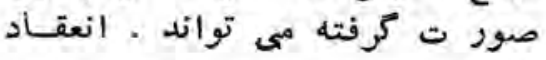
جلسات مجمع عمومى بدعوت مئون تواند

$$
\begin{aligned}
& \text { مديره صورت مى ميرد . } \\
& \text { ماده }
\end{aligned}
$$

هركاه هيئت مديره جلسه فوقاه

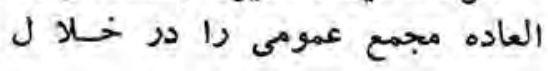

تصويبونه دجمعيت داساسنامــــــ

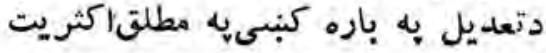

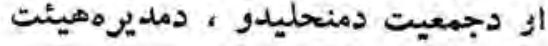

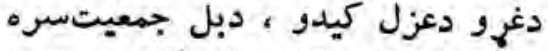

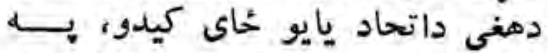

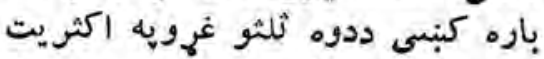

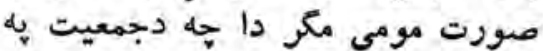

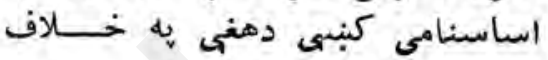
تصريح شوى وى امينامي إن- ماده

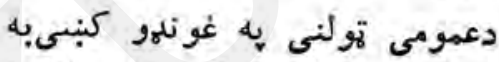

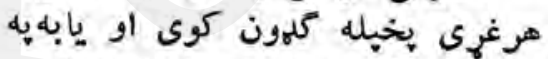

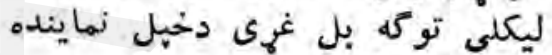

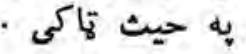
r Tr

عمومى تولنه به دهو مالى كـــال

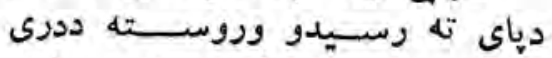

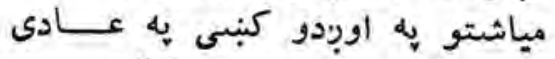

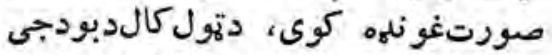

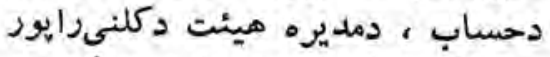

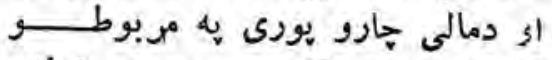

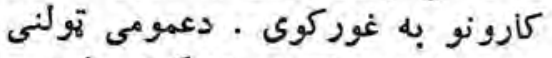

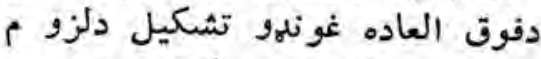

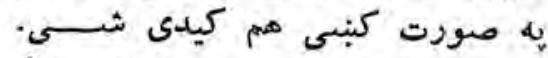

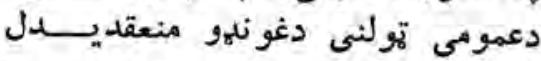

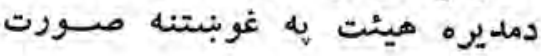

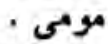
rrr

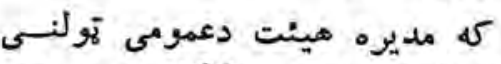

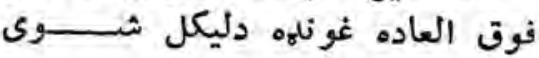




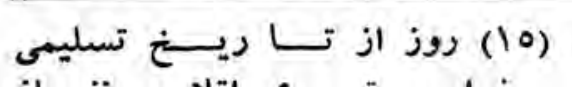

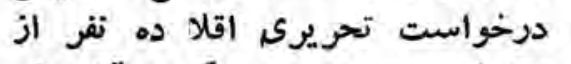
اعضاى مجمع عمومى كه درئ درآنهدف

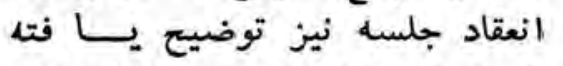

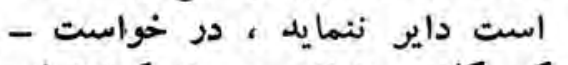

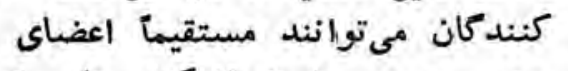

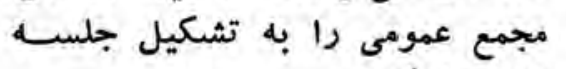

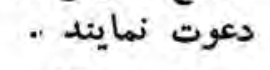

\section{- ماده}

عضو جمعيت در مو ضو ضو عـيكه

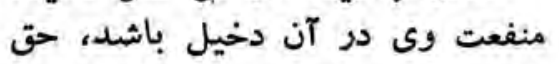
رأى دادن را ندارد . رأى دادن در دري

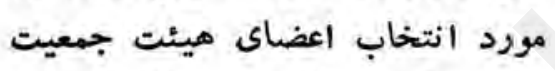

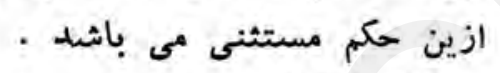

$$
\text { - Ero }
$$

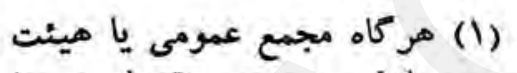

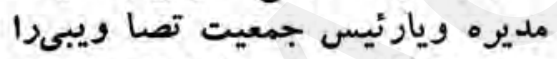

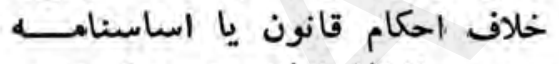

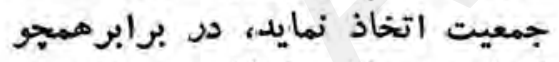

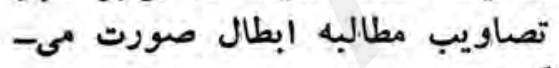

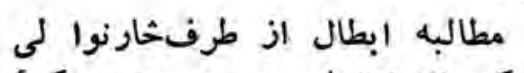

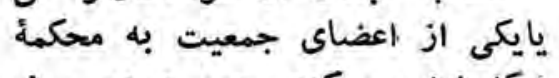

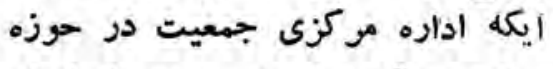

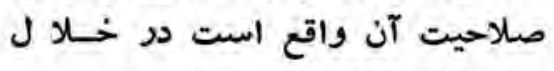
سه ماه از تاريخصدور تصو تصو يـب

$$
\text { تقديم ميكردد ماه تازئ }
$$

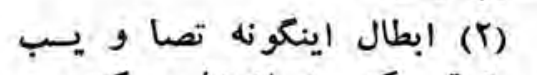
برحقوق مكتسبه اشخال صيكه بـر

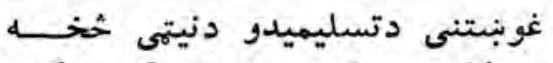

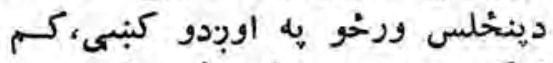

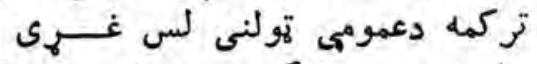

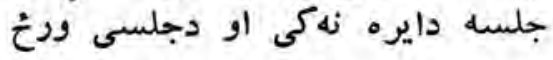

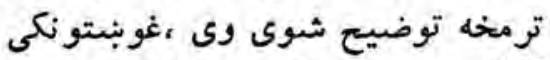

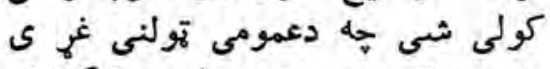

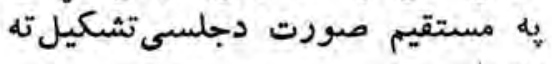
• راوبلى ع ع عـ ماده

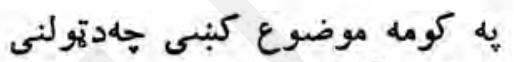

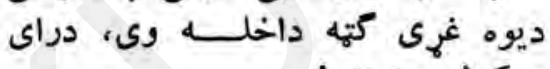

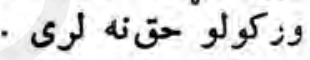

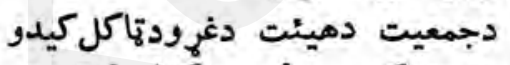

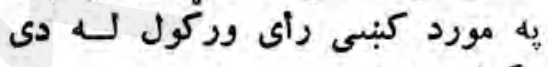

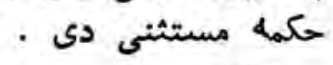

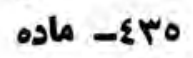
(1)

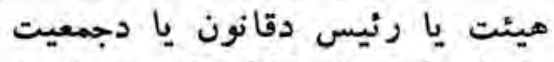

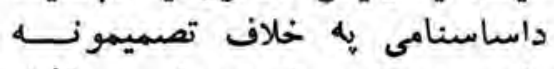

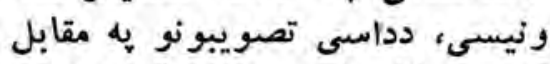
كبنسى دباطليدلو غوبنتينه كيداى تصنى.

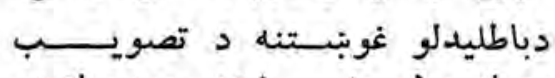
دصادريدلو دنيتهى خخه ددرىمياشتو يه اوجيه

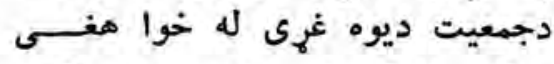

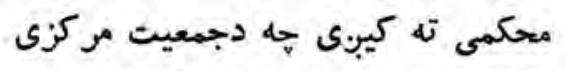

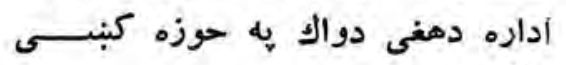
واقع ده .

(r) ددى قسم تصويبونو باطليدل

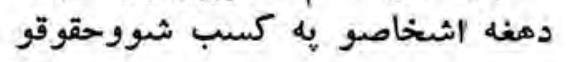




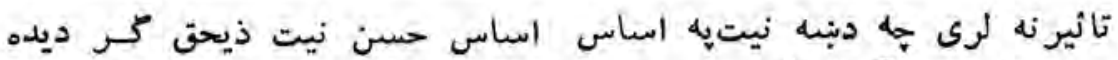

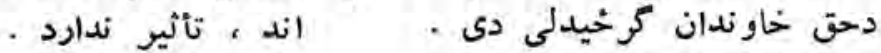

$$
\begin{aligned}
& \text { - ماده }
\end{aligned}
$$

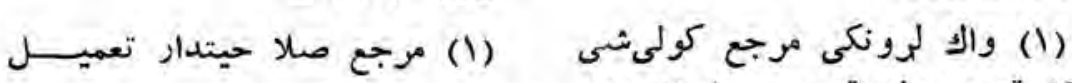

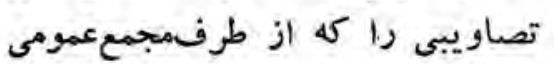

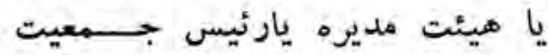

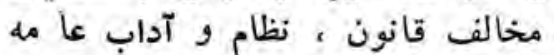
انخاذ شده باشد، متوقف ميسازئ

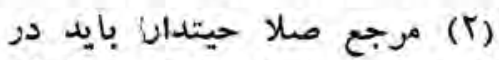
خلال (•r) روز از از تاريخ توقفآن

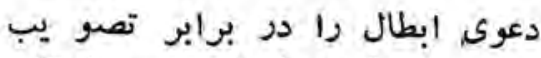

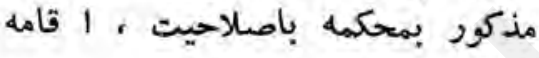
نمايد . مدور

فرع حارم - انعلال و تصفيـــ جمعيت - ETV مادم

ها :

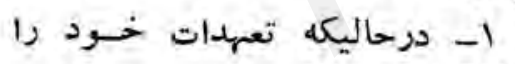

$$
\text { ايفا كرده نتواند . }
$$

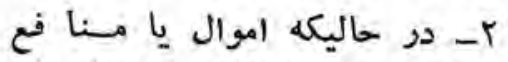
خودراخازج ازاهدأفيكه دراساسنامه المانه

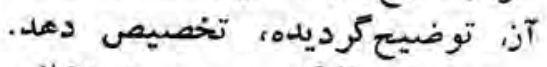
r- در حاليكه جمعيت به تخديده تخلف

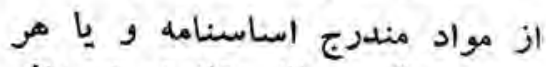

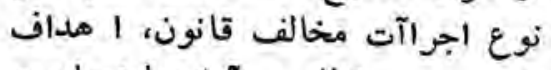
تاسيسى ، نظعام و و آدابع مخامهمبادرت

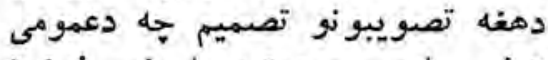

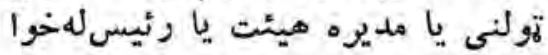

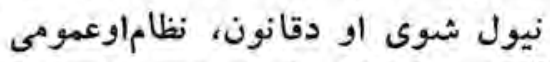

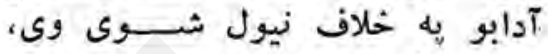
متوقف كى آنى

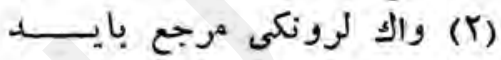

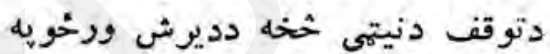

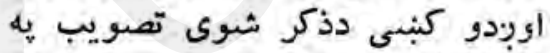

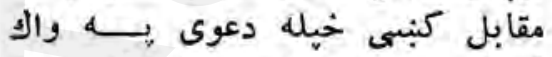

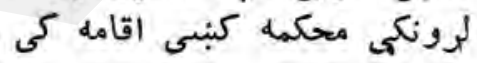
خلورمه فرعه - دجمعيت منتحليدل

\section{او تصفيه كول} ماد E RV

(1) جمعيت به راتلو نكو ماده حالونسو كنبى منحل كيبيى :

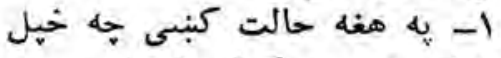

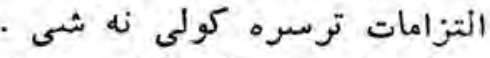

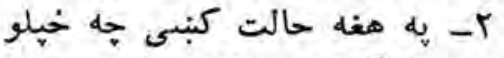

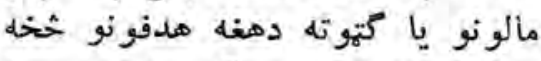

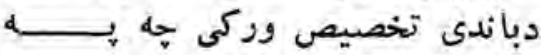

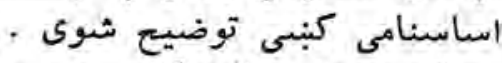

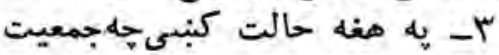
داساسنامى ددرجشووموادويهتخلف

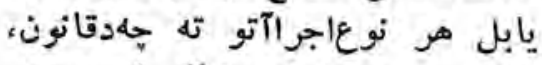

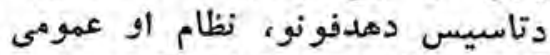

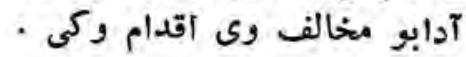




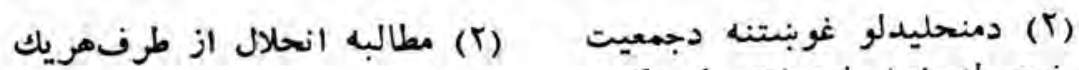

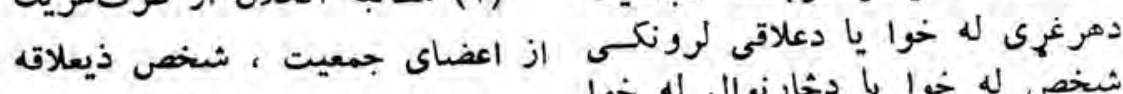

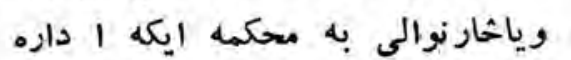

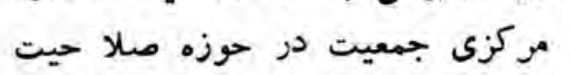

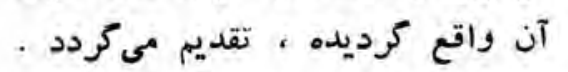

$$
\text { - ع }
$$

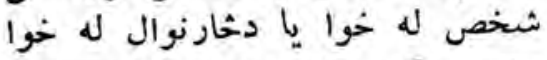

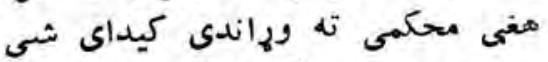

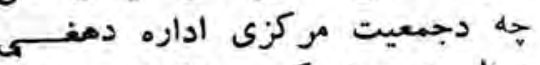

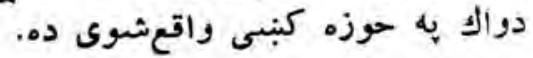
هر كاه محكمه با نحلال جمعيت

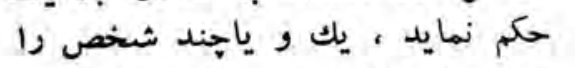

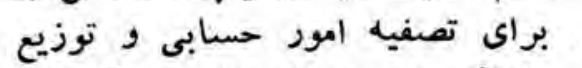

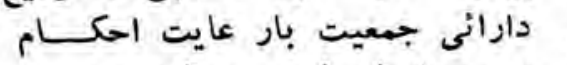

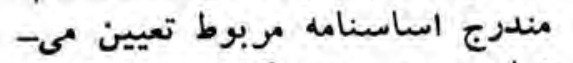

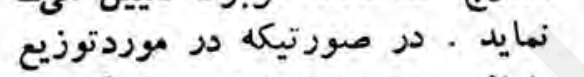

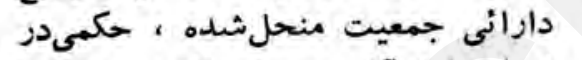

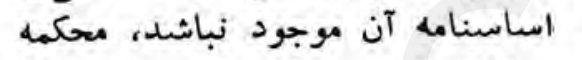

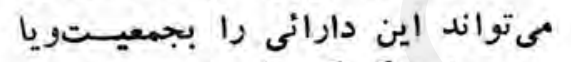

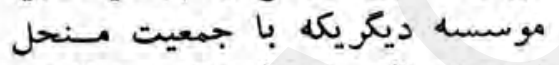

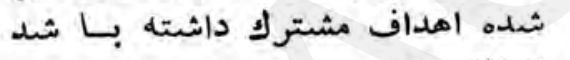
انتقال دمد .

$$
\text { - }
$$

كه محكمه دجمعيت به ماده منحليد لو لو

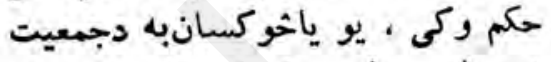

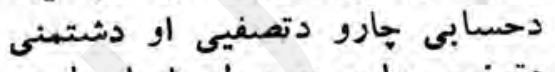

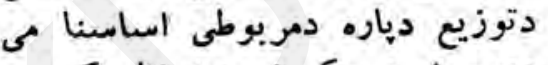

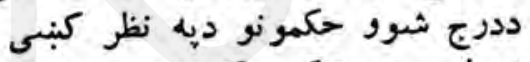

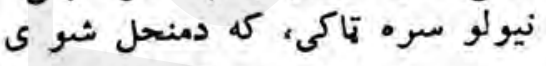

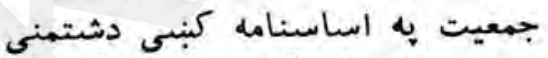

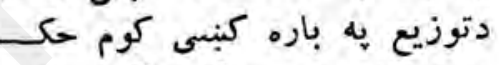

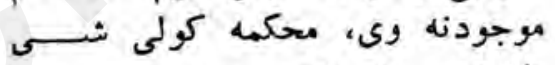

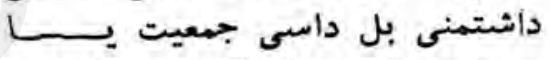

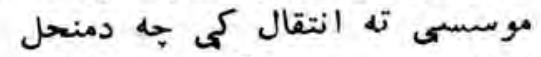

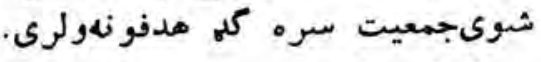

$$
\text { (2 }
$$

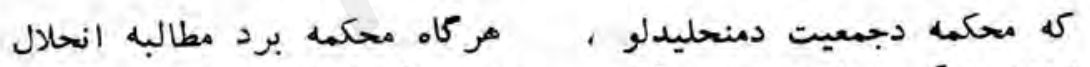

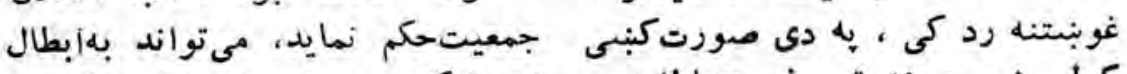
كولى شى دهغه تصرف به به باطليدو

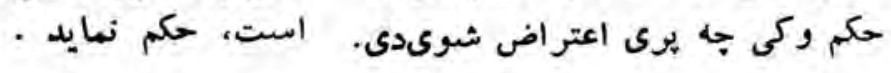

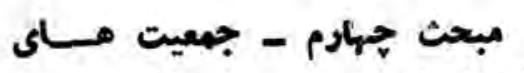
عام المنفعه

$$
\text { - ماده }
$$

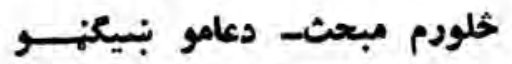
جمعيتونه

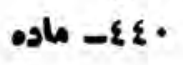

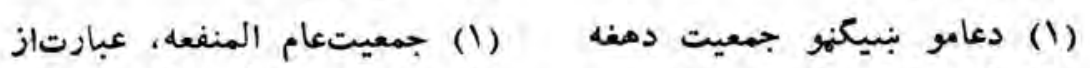

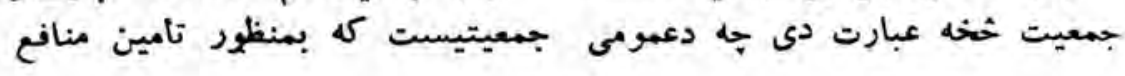




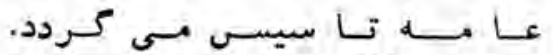
عاعل (T)

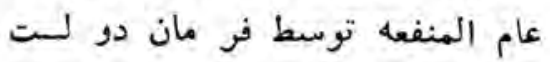
صورت مى كيرد . سلب عنواناعطاء شده توسط جنين فرمان نيز جـوراز مارد - ماده

جمعيت عام المنفعه بر عايت شرايط اهليت مربوط به تملك اموال منقول وغير منقول مقيد نمى باشد .

$$
\text { - El }
$$

حدود استفاده جمعيت عامالمنفعه

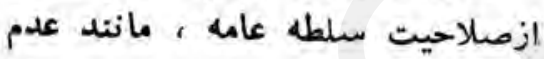

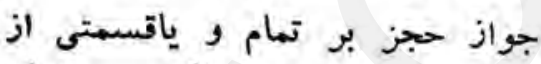
اموال جمعيت ، عدم تأير مرورزمان

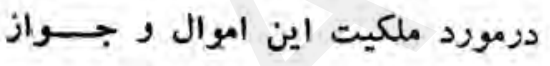

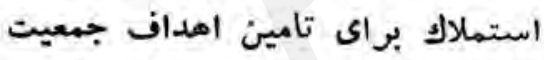

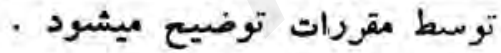

$$
\text { - Ell }
$$

جمعيت عام المنفعه تحتمراقبت

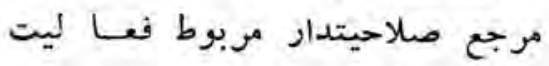

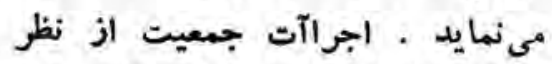

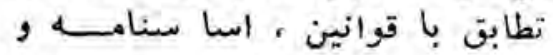
تصاويب مجمع عمومى توسط موجع مذكور مورد تفتيش و تحقيق تسرار
بنبيكهودتامين يهمنظور تاسبيسيبوى جمان (T) (T)

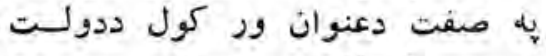

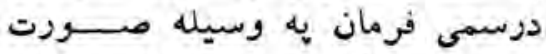

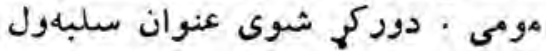

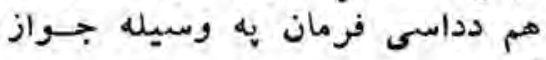
لوى . - إنم إ) ماد

دعمومى بنيكنو جمعيت دمنقولو

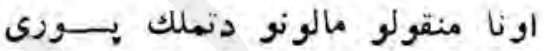

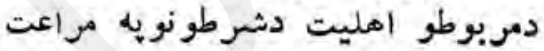

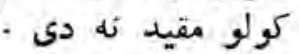
r

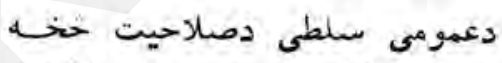

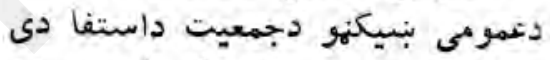

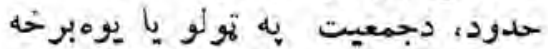

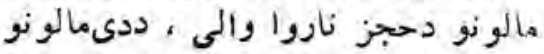

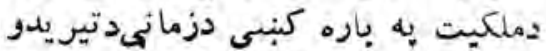

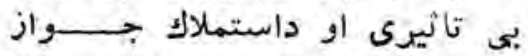

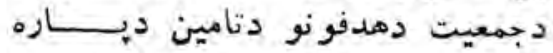

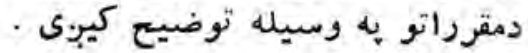

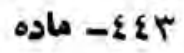

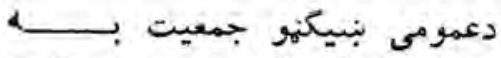
دمربوط والك لرونكي مرجع دمر اقبريت

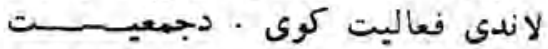

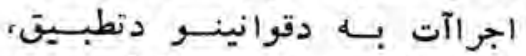

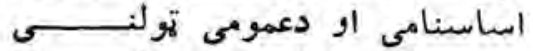

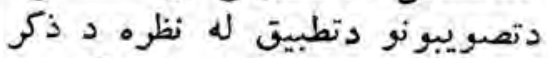

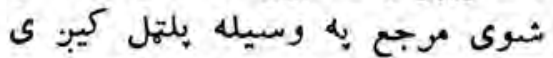

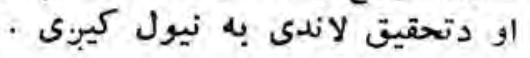




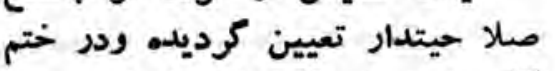

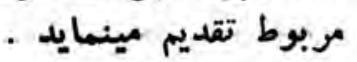
- ماده

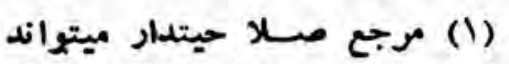

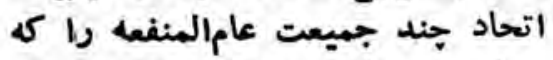
هدف مشترك داشته باشند تصند تصويب

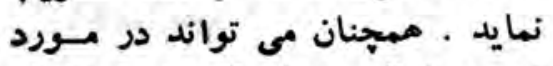

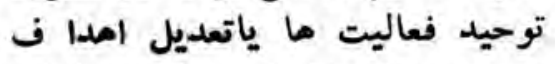

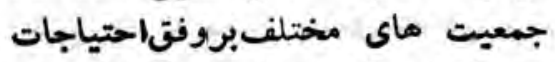
محيط يابمنظور ايجاد مر آ منكى مينين

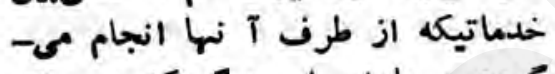

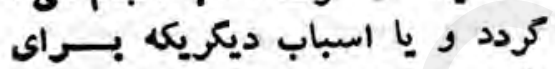

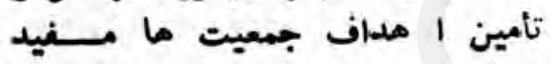
بنداشته شود ، تصمير اتخاذنمايد.

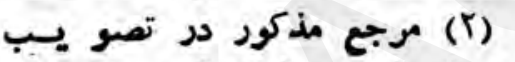

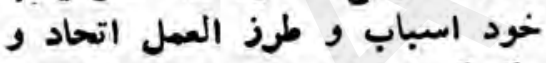

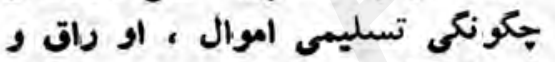

\section{- E\&o ماوه}

هينت تفتيش از طرف مر جـــــ

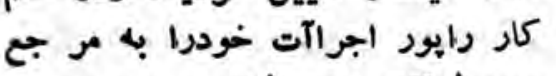

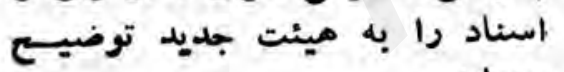

دتفتيش هينت دصلاحيت لرونك

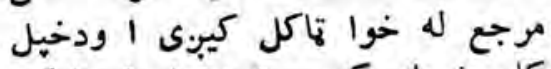

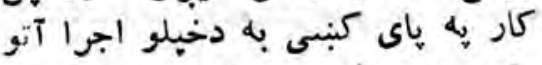

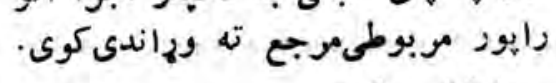

$$
\text { نع }
$$

(1) واك لرونكى مرجع كولى شیى مادى

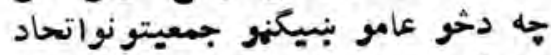

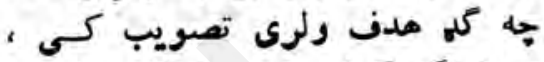

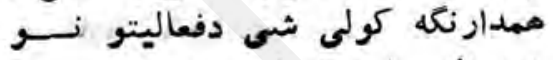

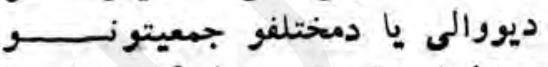
دهدفونو دتعديل به به بارهكنيس دمحيط

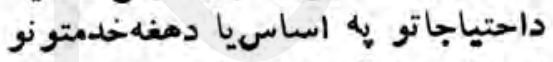

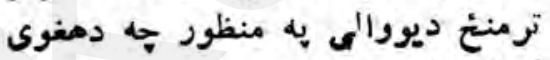

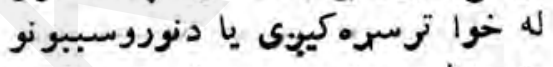

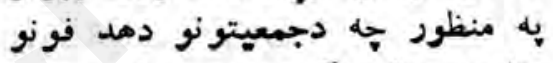

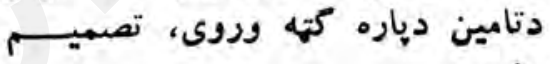
تو (r) ذكر شوى مرجع به بنيسل

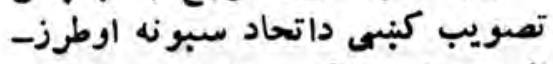

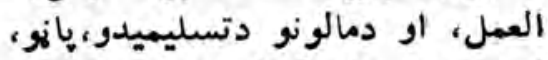

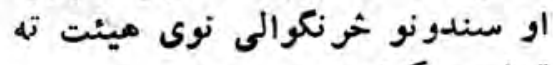
توضيح كوى ماون

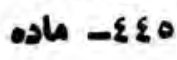
افو (1) مرجع صلا حيتدار مى تواند

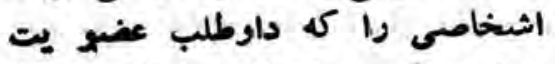

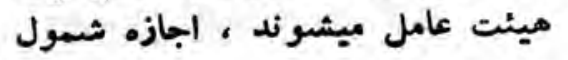
ندمد . ن (1) واك لرونى مرجع كولى شيى

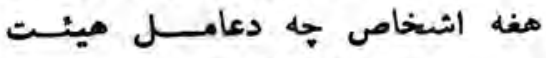
دغريتوب داوطلب كيي.ى ، دشامليدو

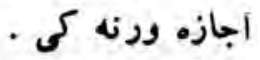

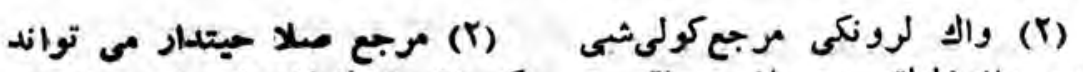

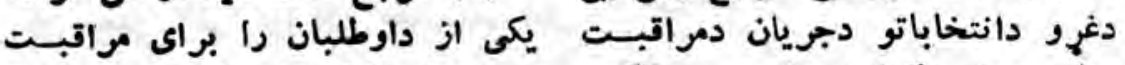

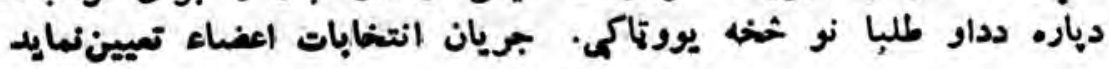


(T) اكر انتخابات مخالفاحكامقانون

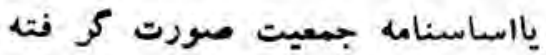
باشد ، مرجع صلاحيتدار قرارمدللى مبنى بر الغاى انتخاب را در خدئلال

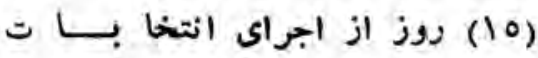

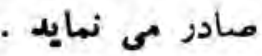
- EET osk (r)

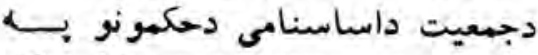

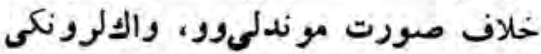

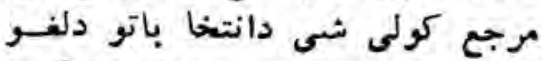

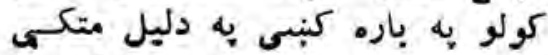

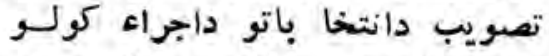

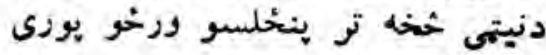
صادر كى .

$$
\text { ه }
$$

(1) بنابر قراد مدلل ، رنيس هيئست

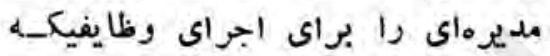
دراساسنامه جمعيت تو ضيع وكرديده موقتأ تعيين نمايد . (T) (T) وقتى تعيين ميكردد كي در اجرين آلت رنيس يا مينت مديره جمعيت جنان تخلفى بروز نمايد ،كه دوام آنهـا بوظيفه بمعلحت جمعيت نبـــوده باوجود اخطار جمعيت و مرور(10)

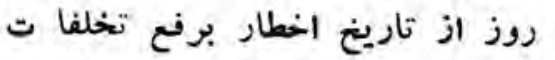

$$
\begin{aligned}
& \text { نيرداخته باشد لمار } \\
& \text { - EEV }
\end{aligned}
$$

(1) اعضاى مينت ملديرهجميعيت

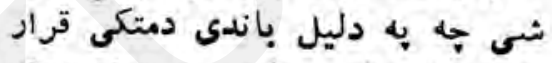

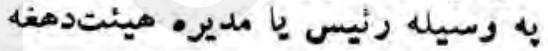

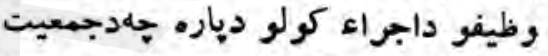

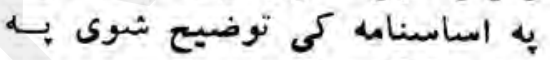

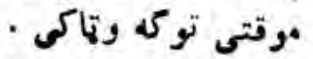

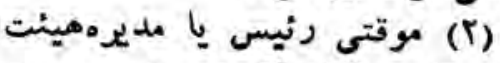

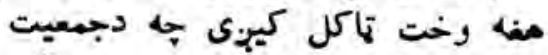

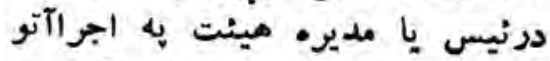

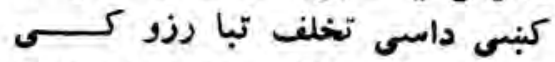

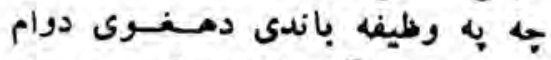

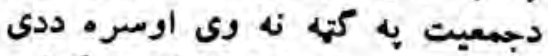
جه دجمعيت له خوا اخطار وركول شوى وى او داخطار وركولو دنيتى

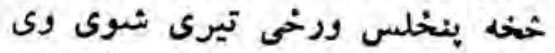

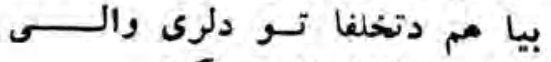

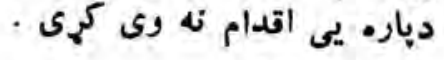

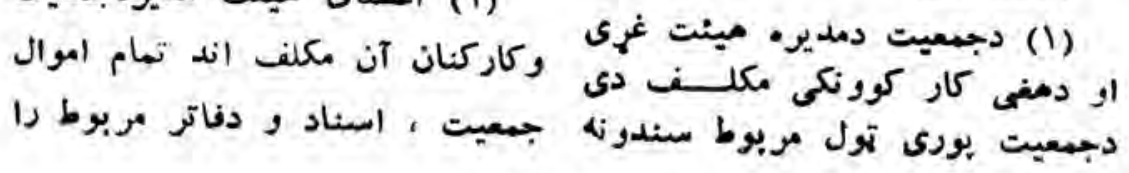


او دفترونه دموقتى عامل هيئت بـه باختيار هينت مديره موقت بكذارد.

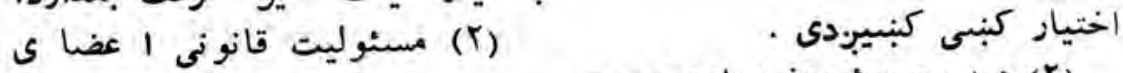

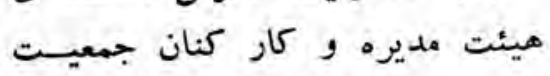

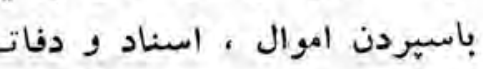

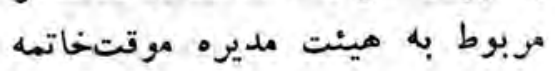

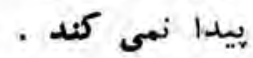

\section{ماده}

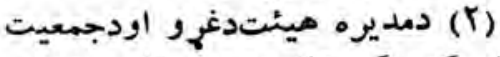

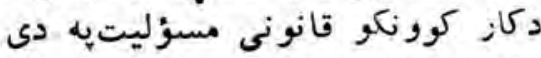

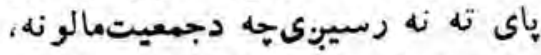

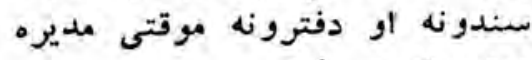
هيئت ته وسبارى اون دونت ه

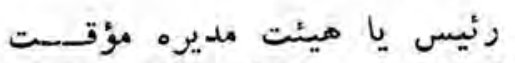

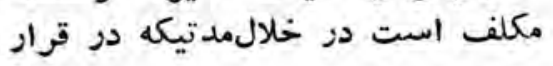

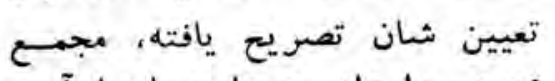

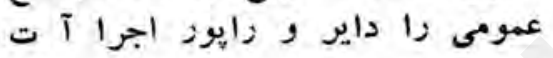

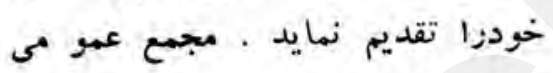

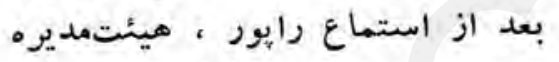
جديد را مطابق به اساسنامهواحكام قانون انتخاب مى نى نمايد

$$
\text { - E\&9 ماد }
$$

جمعيت به تطبيق تصاويبرئيس ويا هيئت مديره مؤقت كه در داخل هدت معينه هندزج قرار ، تعيينشان صورت كرفته ، دز داخل حدوديكه فيكه درقرار مذكور و, ياساسنامهجمعيت

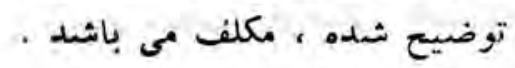

$$
\text { - E0. ماده }
$$

ريس يا مؤقتى مديره مينتمكلف ماده

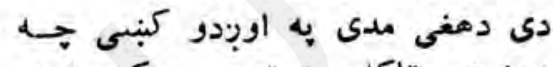

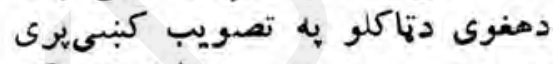

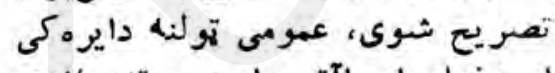

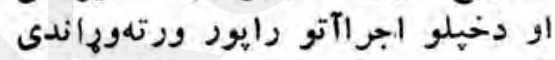

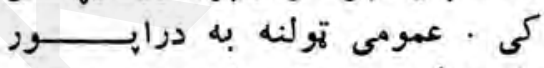

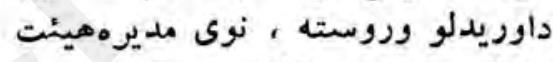

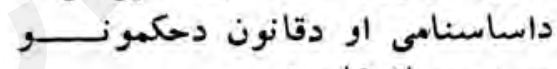

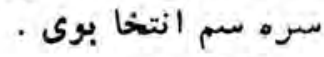

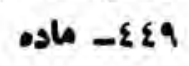

جمعيت دموقتى رئيس يا مدير ماوه

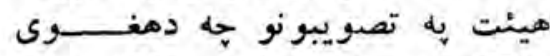

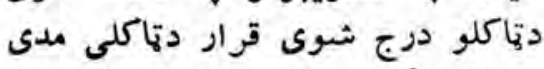

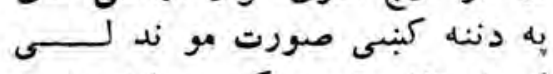

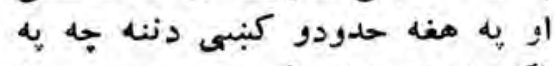

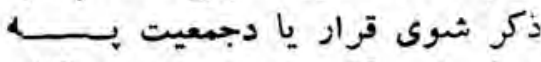

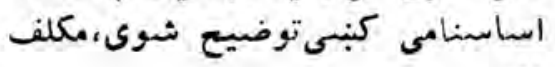
.

ols -20 .

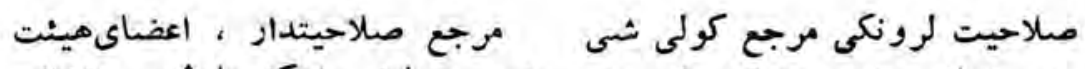

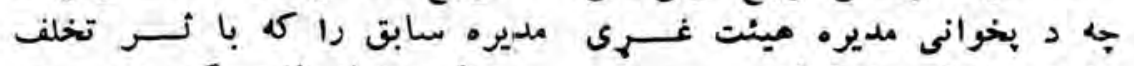

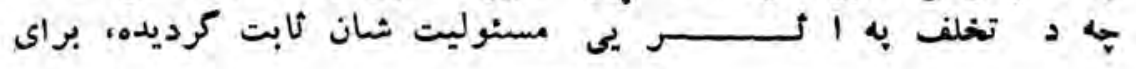


مدتيكه متجاوز از سه سال نباشد،

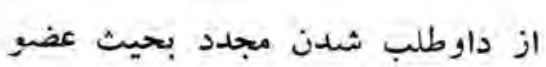

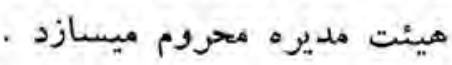

مبحث خنجم - جمعيت خيريه - E01

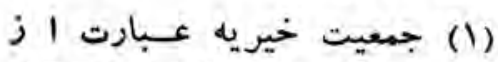

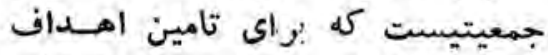

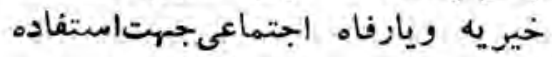

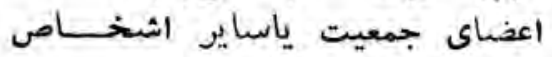
تاسيس شاع شده جاشعد .

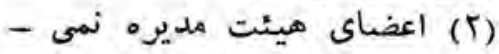

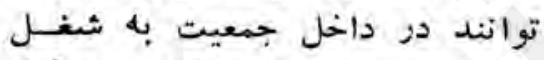

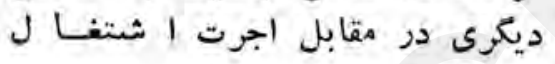

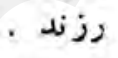

$$
\text { - Eor ماده }
$$

مكيئت مديره (1) مكلف به تهيه راليوز اجرهآت مالانه مى مكاشد

هو (r)

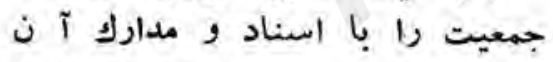

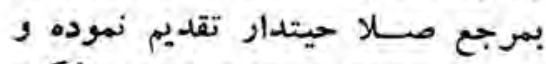
رعلومات موزد ضرورت مرجع مذكور

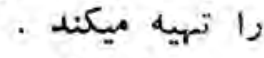

مبحث شثم - جمعيت فرهنكى

$$
\text { - Eor }
$$

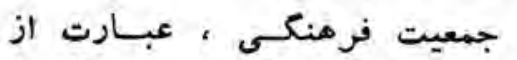
جمعيتيست كله مدف تاسيس آ آن نرا

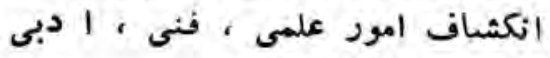

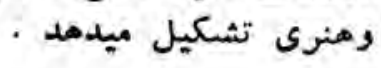

مسؤليت ثابت شوى ديوى مدىدياره

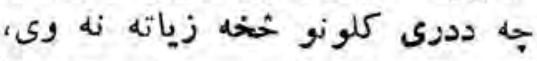

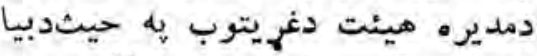

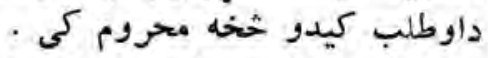

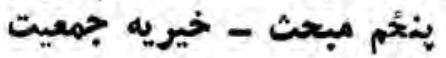
0-

(1)

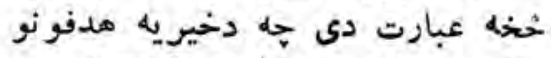

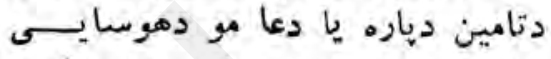

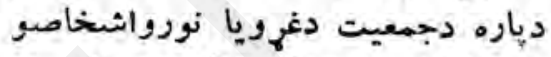

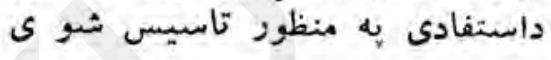
و وى

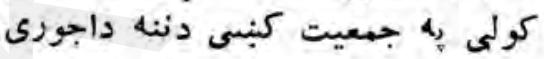

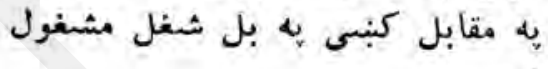

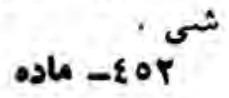

دكن (1) دكلنى دايود داجرا آتو به به برابرولو مكلف دى مان.

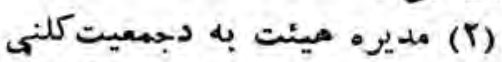

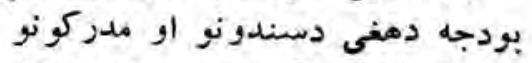

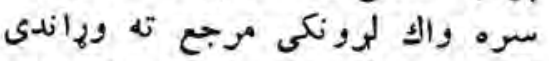

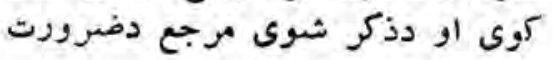

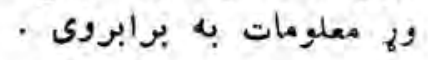
شير.م مبحث- فرهنكى جمعيتونه os - 2 or

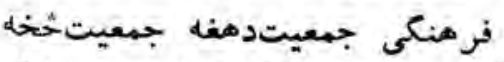

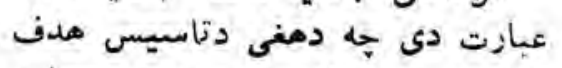

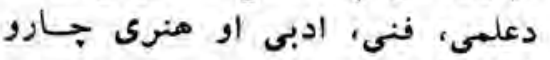

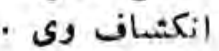




\section{- Eo\& oslo}

ع عـ ماده

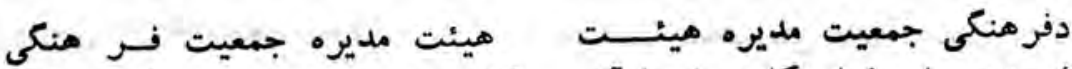

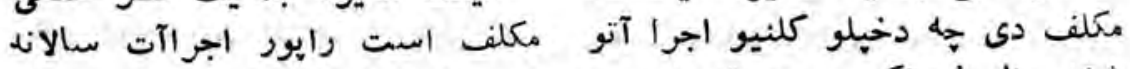

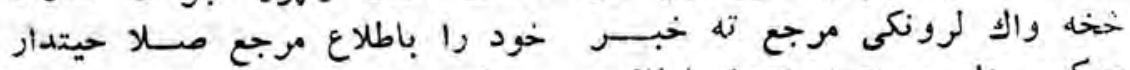

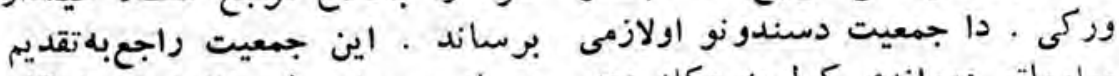

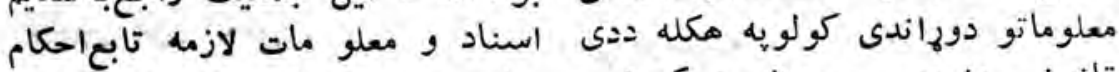

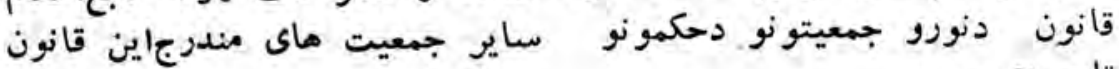

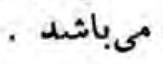

$$
\text { ماده مبحث هفت - موسسات }
$$

مو سسه ، معبـار ت از از شخصيت

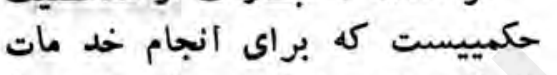

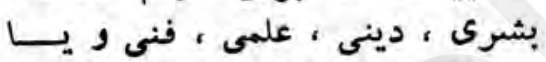

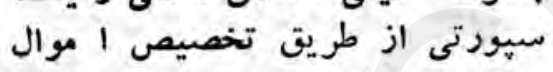

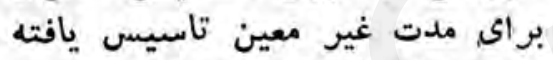

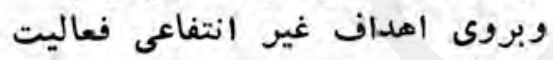

$$
\text { مى ملهايد . ماده اهد }
$$

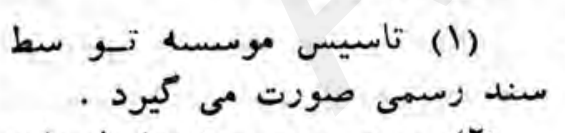

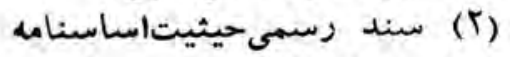

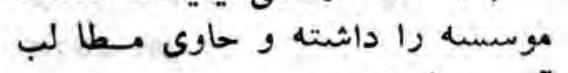

$$
\text { آتى ميباشد : موراش }
$$

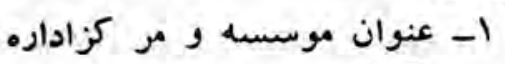

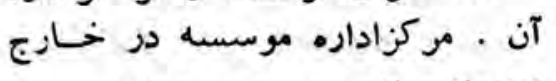

$$
\text { ازافغانستان بوده نمى توان مواند }
$$

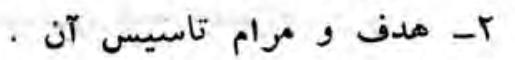

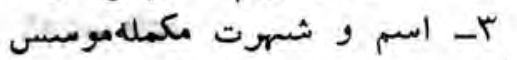
• يا موسسين

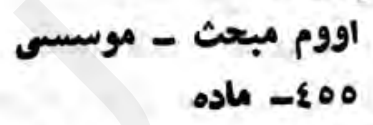

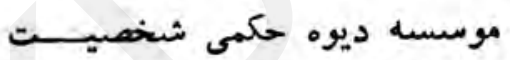

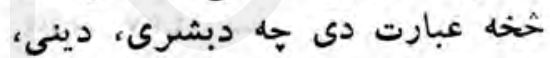

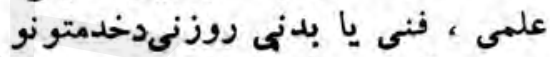

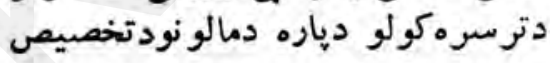

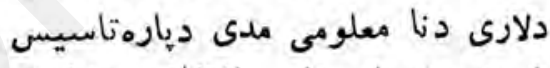

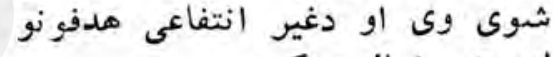

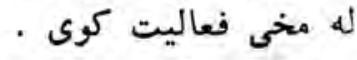
7.

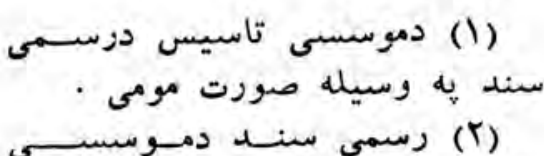

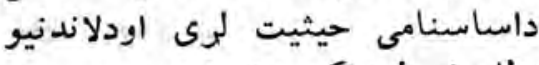
مطلبونو لرونكى وى : لريثي

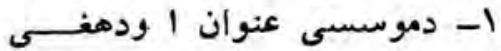
دادارى مركز، موسسه نه نه شئ كوان ودمنى

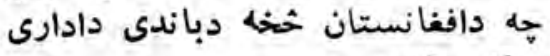

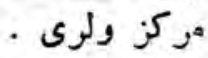

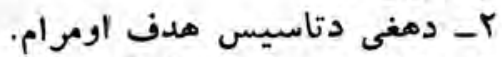

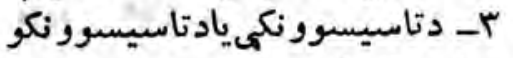
غهو نومونه او دهغوى يورهشيهرت. 
ع- تفصيلات دازانى إيكه بـــــ

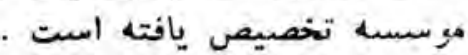
0- تشكيل ادارى موسسه واسم اسمي زئيس آن . .

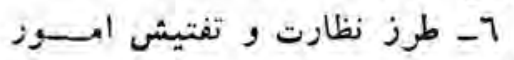

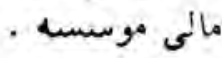

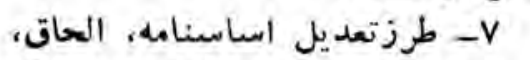

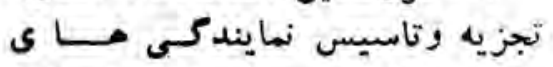

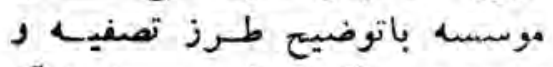

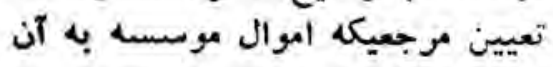

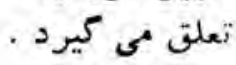

$$
\begin{aligned}
& \text { - EOV ماد }
\end{aligned}
$$

هر كاه عضو موسس ، ماده

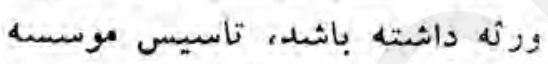

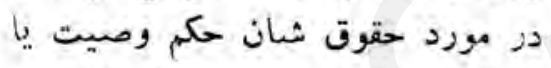

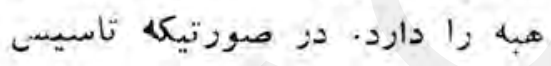

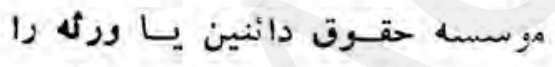

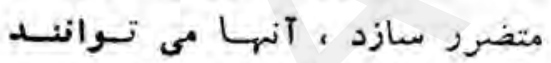

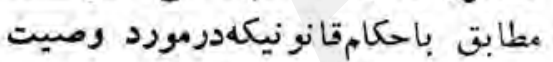

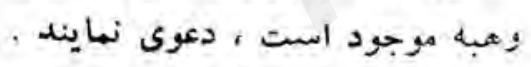

$$
\text { - EON ماده }
$$

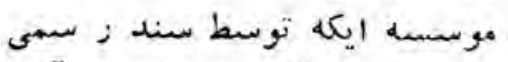

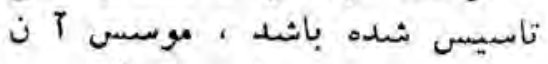

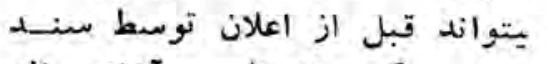

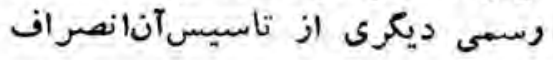

$$
\text { - E09 010 }
$$
نمايد

شخصيت حكمى موسسه و قتى
ع- دهغى شتمنى تفصيلات جـ

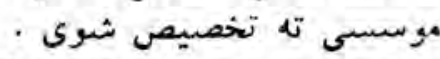

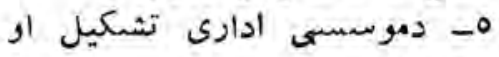
دمغى دزئيس نوم دمبس

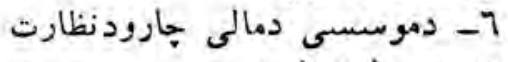
او تفتيش طرز العمل

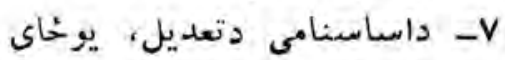

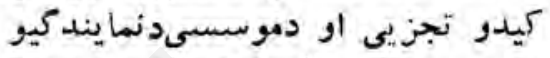
دتاسيس طرز العملدتصفيى اودنوضيح

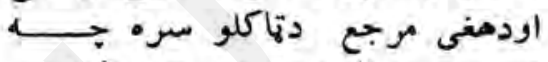

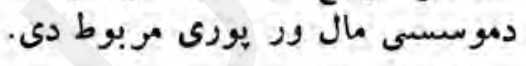
أiov

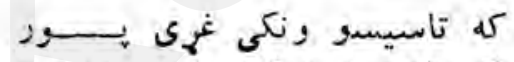

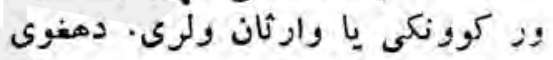

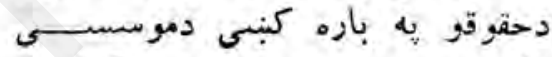

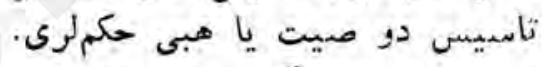

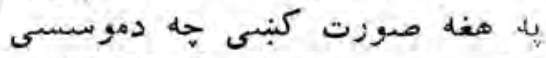

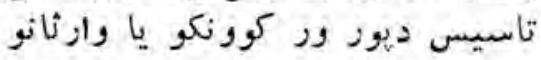

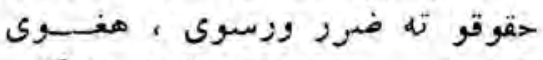

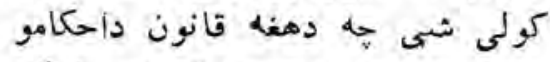

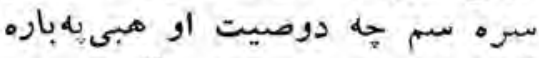
كبنى هوجود دى دعوى دور وكى

$$
\text { ols }-201
$$

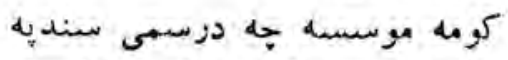

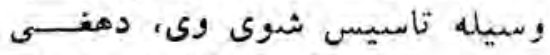

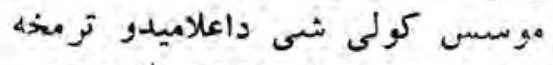

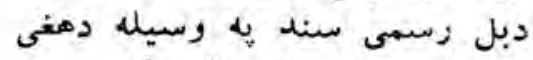
دتاسيس خخه انصبر اف وكى .

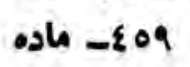

دمرسسى حكمى شخصيت هغ 
وختثبيتيبنى جه ددى إنانوندحمونو تثبيت ميكردد كه مطابق باحكام اين

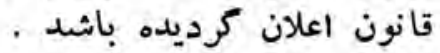

$$
\text { - ماده }
$$

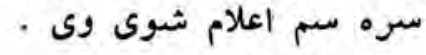

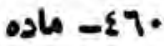

اعلان موسسبه بمطالبه موسس يأيس

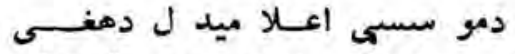
اولينرئيسآن ويامرجع وطلاحيتداريكه

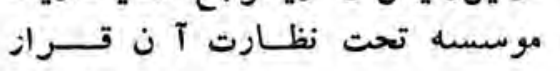
دارد ، مطابق باحكام مربوطبهاعلان

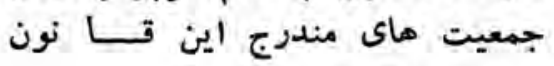

$$
\text { صورت ميكيرد . ماده ماك مات }
$$

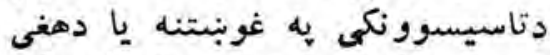

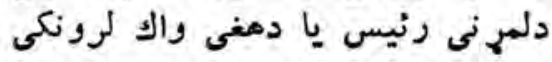

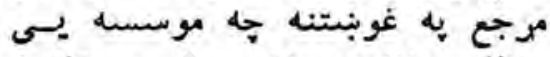
دنظارت لاندى واقع ده ده دوى قانون

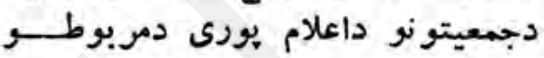

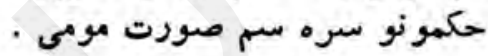

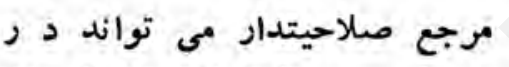
مورد تاسيس، طرز إدارمواساسنامه مئه تواند

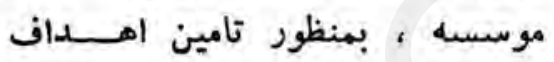

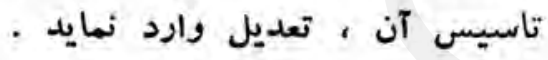

$$
\text { - Elr }
$$

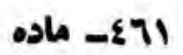

والك لرونكى مرجع كولى شيى جاله

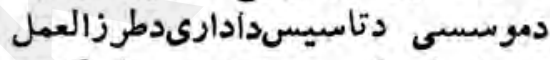

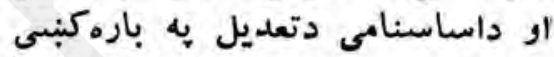

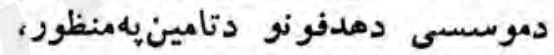

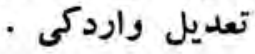
موسسه توسط رنسيس اداره و

$$
\text { تمثيل ميكردد - ماده }
$$

$$
\text { rרז ماده }
$$

موسسه درئيس به وسيله اداره • او تمثيليب:ى

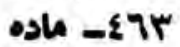

رئيس موسسه ،بودجه وصورت

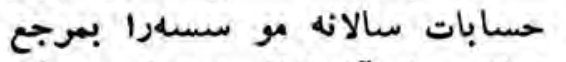

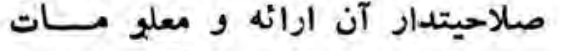
مورد ضرورت مرجع مذكوررا تهيه

$$
\begin{aligned}
& \text { مى مهايد . مورد } \\
& \text { - Ele }
\end{aligned}
$$

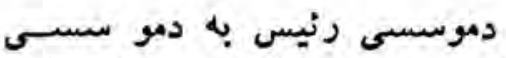
كلنى بودجه او دكلثيو حسابو نسو

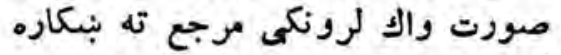

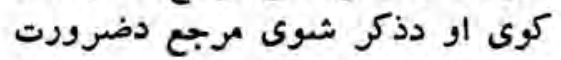

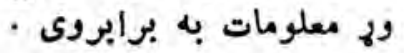

موسسه نسى تواند بدون اجازه

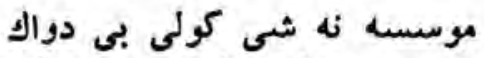

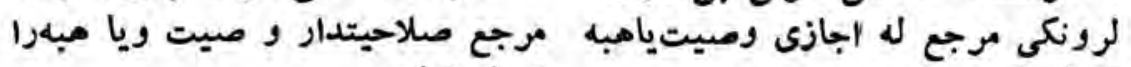
تبول نمايد موجاحيتد

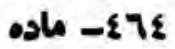




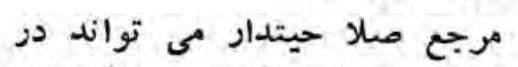

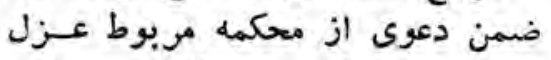

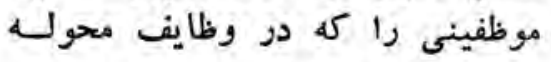

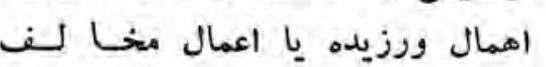

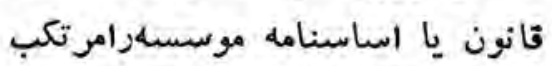

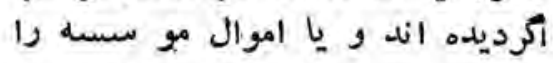

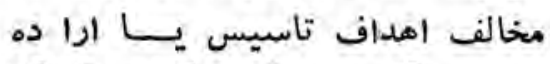
موسس آن بمعرفرسانيده يااينكه

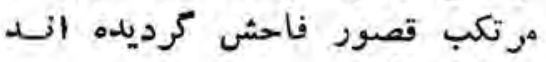
مطالبه نمايد . مادب - E7T osco مرجع صلاحيتدار مى تواند براي

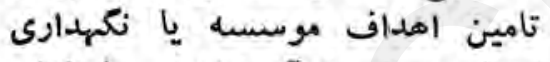

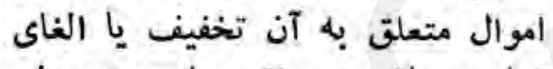

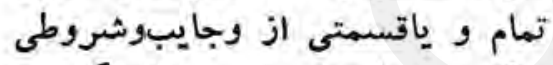

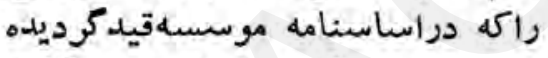
است ، از معكمه باصلا حيتمطالبه

$$
\text { - عاده }
$$

هر كاه رئيسموسسهمخالفقانون،

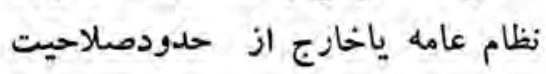

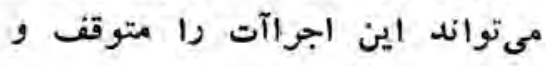

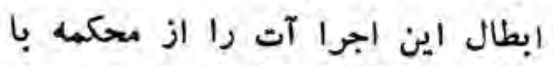
صلاحيت مطالبه نمايد آن آن

$$
\text { - ET1 }
$$

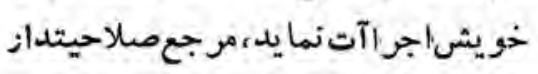

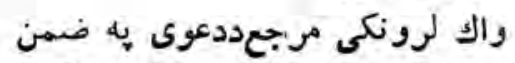

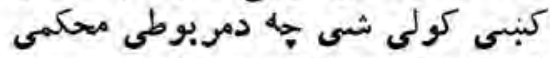

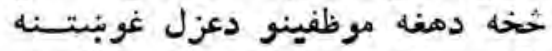

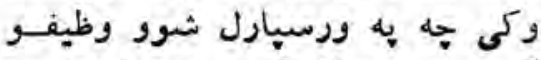

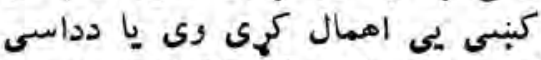

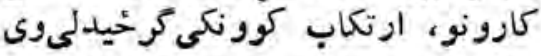
جه دقانون يا دموسسى داساسنا مى كى

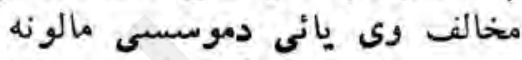

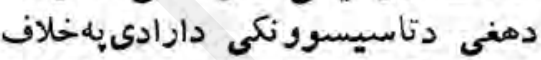

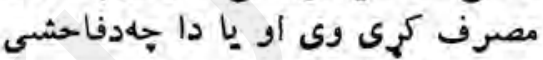
قصور ارتكاب كوونكى شوى وى ول טاد

والك لرونكى مدجع كولى شى مادى جها

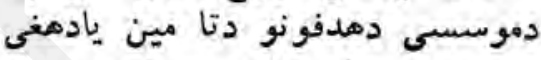
يورى دمربوطو مالونو دساتنى دياره

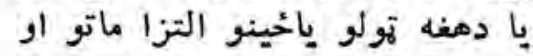

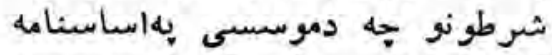
كى قيد شوى دون دلغو كيدو غوبنتئه وكى مادى

كه دموسسى رئيس د قانو ن يا يا

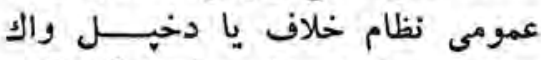

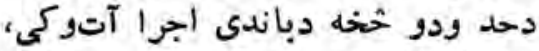

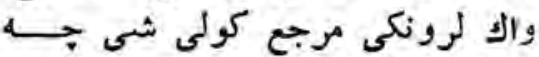

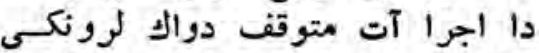

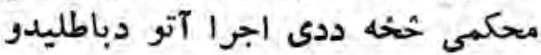
غوبنتيه وكى مجنى 1

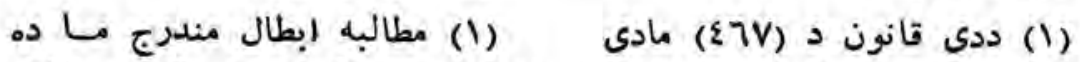

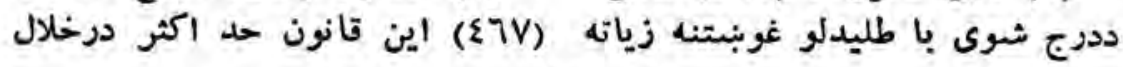


يكسال از تاريخ اجرا آت، بهمحكمه

اندازه ديوه كال يه اوبِ دو كبنسى تقديم مى كردد .

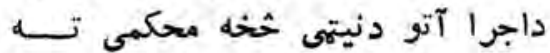
(r) ابطال اينكو نه اجرد آنه بر حقوق مكتسبه اشخا صيكه بـر آنرا دماند (r) دداسيى اجرى آتو با طليـدل

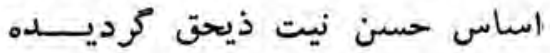

$$
\text { اند ، تاثير ندارد . ن ادسن }
$$

\section{- \&79}

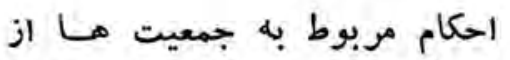

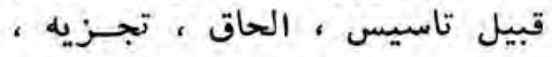

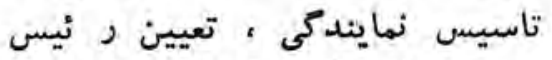

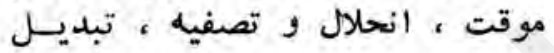

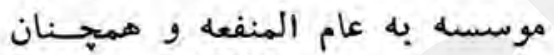

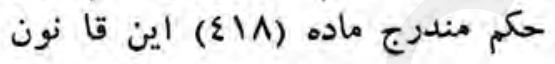
برعموم مو سسات نيز قابل تطبيق

$$
\begin{aligned}
& \text { مىباشد . } \\
& \text { - EV. ماده }
\end{aligned}
$$

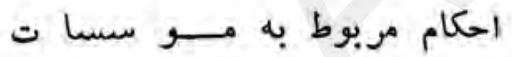

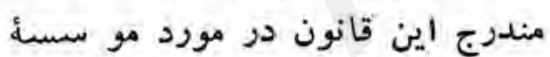

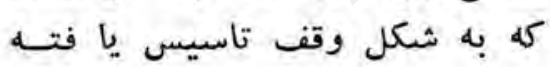

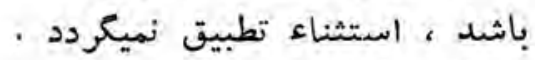

$$
\text { - EVI ماده }
$$

اتخاذ تدابير دز برابر تخلفا ت

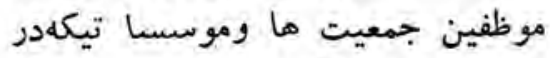

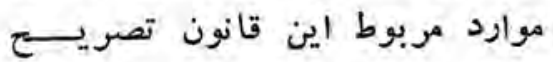
يافته ، مانع تطبيق قانون جــز إنى

$$
\text { عمومى نمى كردد . }
$$

دهغه اشخاصو يه كسب شورحقو آنو

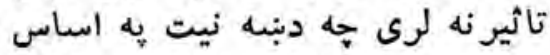

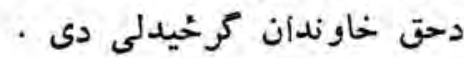

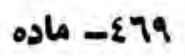

دجمعيتونو يورى مربوط حمدونه

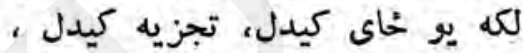
دنمايندكيو تاسيس ، دموقتى دئيس

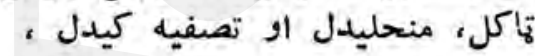

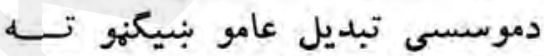

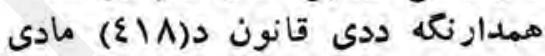
درج شوى حكم يه عمومو موسسوميم

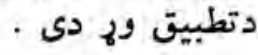
عV.

نه دى قانون كنبىدموسسويورى

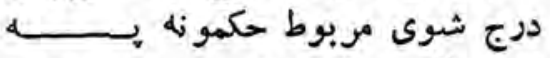

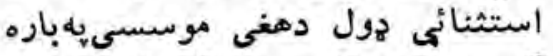

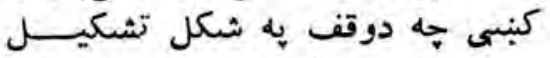
شوى وى نه تطبيقيبن

$$
\text { أن }
$$

دجمعيتو نو او موسسو دهغــــ ملهد

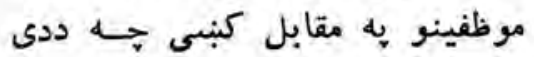
قانون به موادو كنبى دتدبيرونونيول تصريح شوى دجزاء دعمومى قانون دوني دوني دتطبيق مانع نه كرخى . 


\section{فصل سوم

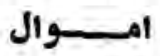 \\ - Evr oto}

دريم فصل

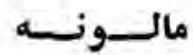

reVr

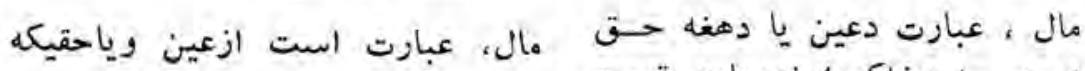
تزد مردم قيمت مادى داشئه باشد.

$$
\text { - Evr }
$$

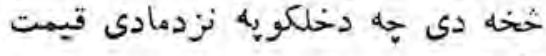
•

اشيائيكه بمقتضاى طبيعت و و بياه كوم شيان جه دطبيعت به به اقتضاء بحكم قانون مورد داد وستد قترار

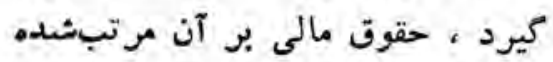

$$
\text { - عVE مادواند }
$$

اشيائيكه بمقتضاى طبيعت مورد

داد و ستد قرار كرفته نتواندعبارت طينائ مورت

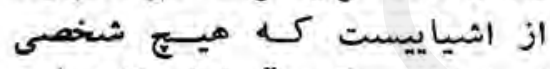

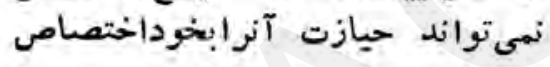
-

\section{- EVo olo}

اشيا ئيكه بحكم قانون مورد داد و

مسته قرار كر فته نمىتواند عبارت اشياييست كه حقوق مالى برآن فئن قانوناً مرتب شده نمى تواند.

$$
\text { - EvT }
$$

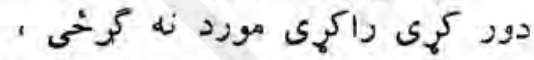

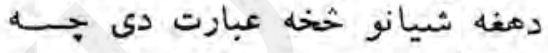

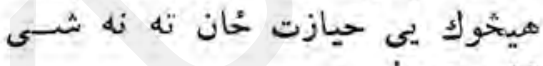$$
\text { - تخصيصولى }
$$

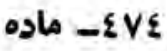

كوم شيان جه دطبيعتيه أقتصاء يا دقانون ،يه حكم دور كئى راكئي مورد كرخيى ، مالى حقوق يوى دمرتب كي.ي.ى

$$
\text { ¿Vo }
$$

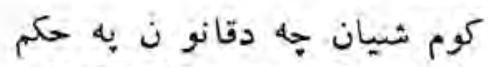

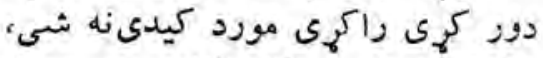

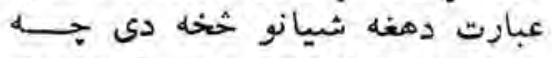

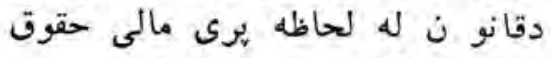

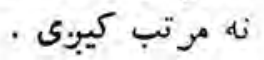
ـ

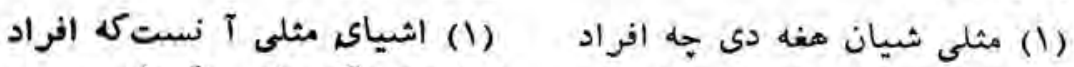

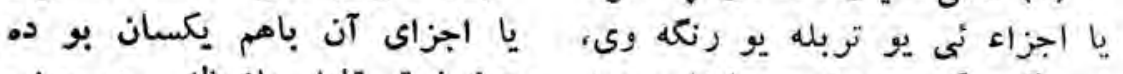

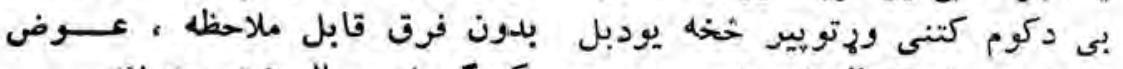

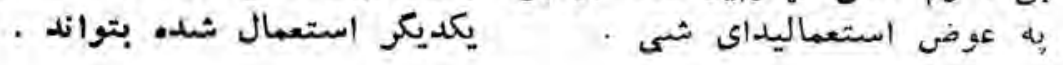




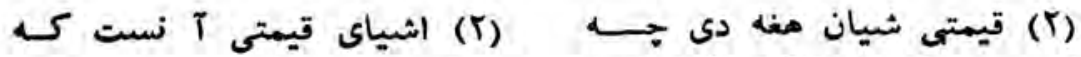

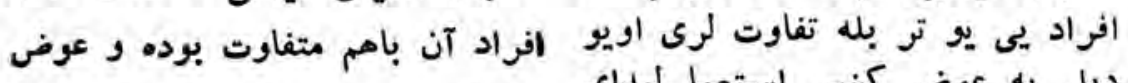

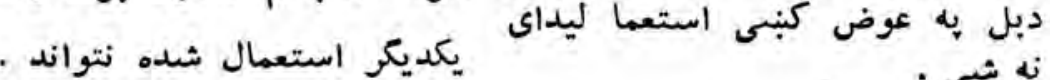
- EVV ماده EVV

م

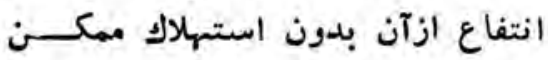

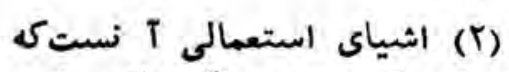
نباشد انفاع آن باانتفاع مكرر ، عين آن باقىيماند.

$$
\text { - EVA ماده }
$$

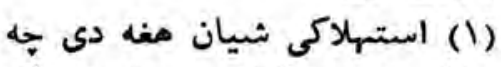

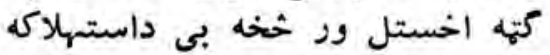

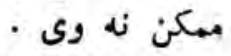

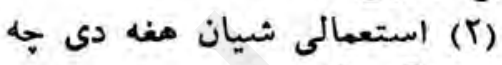

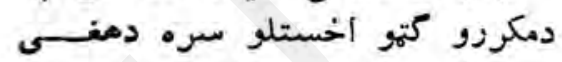

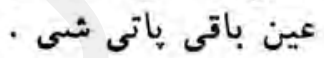
¿

عقار اشيايست كاده دارد

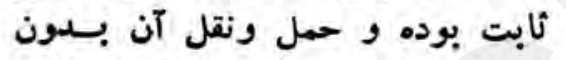

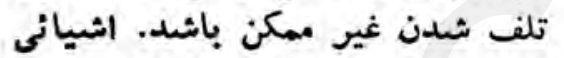

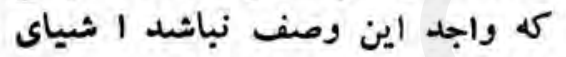

$$
\text { منقول شناخته ميشود . EV9 }
$$

اشياى منقولى راد كاد ماده مالك بواي

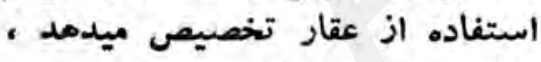

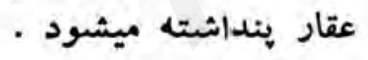

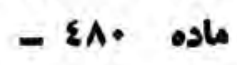

هر حق عينى مربوط به عقار وهر دعوى متعلق به آن عقار شينـ خته شده ، حقوق مالى غير آن از جمله

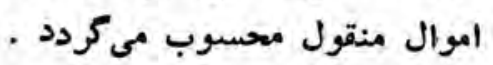

$$
\text { ماده }
$$

عقار عبارت دمغه شيانو خخه دى اون اون اون

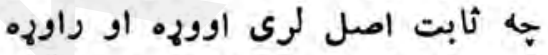

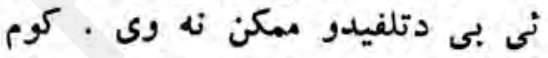

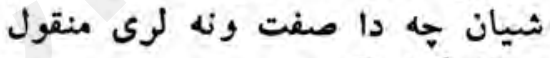

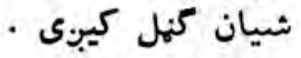

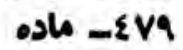

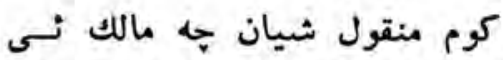
دعقار داستفادى دياره تخصيصو

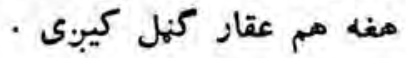

$$
\text { • }
$$

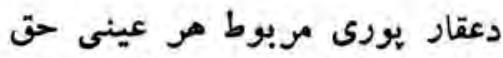

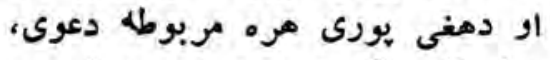

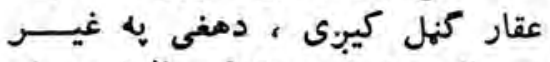

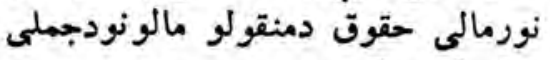

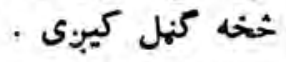

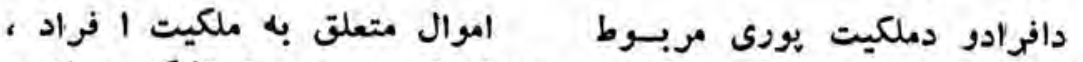

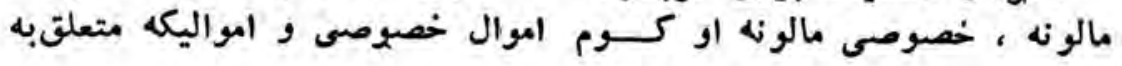




\section{مادى ( $(\varepsilon \Lambda F-\varepsilon \Lambda F)$}

ملكيت افراد نبوده و براى منـافع ومصالح عامه تخصيص افريافته باشهده

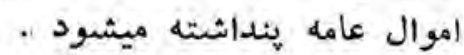

$$
\text { - }
$$

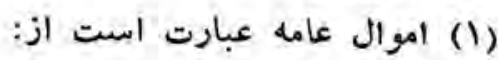

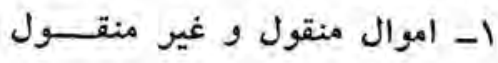
دولت . r- اموال منقول وغير منـقو لـ اشخاص حكمى الموال

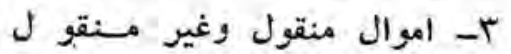

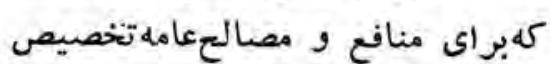

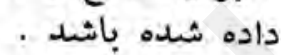

ع- اموال منقول و غير منقول كه بحكم قانون اموال عامه شئ شئ خته

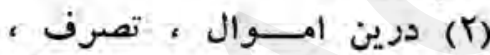

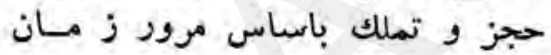

$$
\text { جواز ندارد . مارد }
$$$$
\text { - }
$$

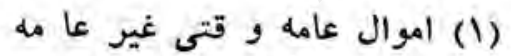

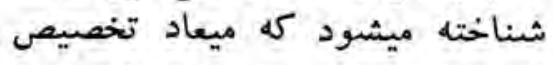
آن براى منافع عامه ، ختم كر ديده باشد . بات (T) ختم تخصيص ب بحكم قـانون يابالفعل و يا بختم هدفيكه ا مــوال

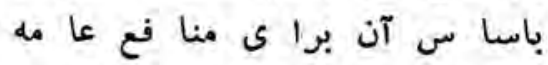
تخصيص داده شده صورتميكيرد.

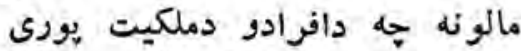

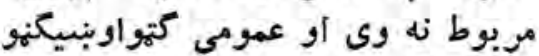

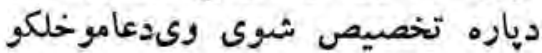
مالونه كنل كئل

$$
\text { هاد }
$$

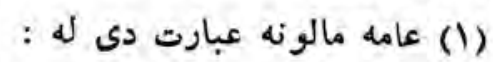

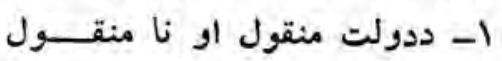
مالونه

كالو دحكمى اشتخاصو منقـــول او نامنقول مالونه

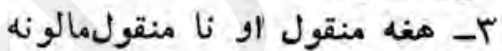
جه دعا مو خلكو دكتو اوبنيكنودياره ع- هغه منقول او نا ونا منقولمالونه

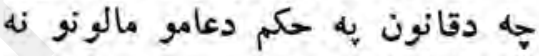
نيز ندل شوى ونان داني

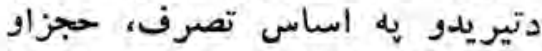
دخيل ملكيت لاندى راوله لدول جواز نه لوى

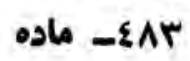

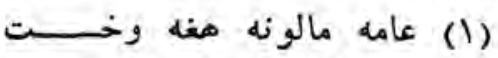

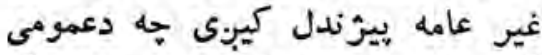

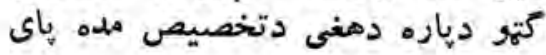
ته رسيدلى وى دون دمن دون

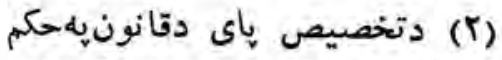

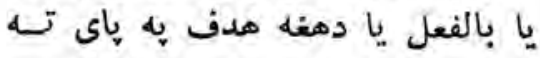

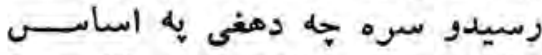

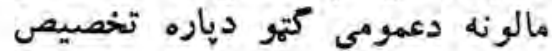

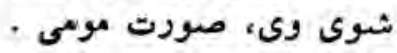




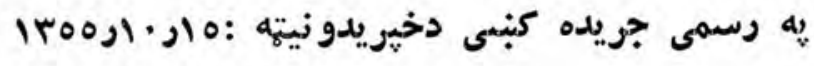

$$
\text { ددى توك بيه: (•) (-1) افغا نى }
$$


دطبع شمير (1700.

دولتى مطبعه 